University of Rhode Island

DigitalCommons@URI

Open Access Dissertations

1987

\title{
Treatment of Refinery Wastewaters Using Various Modified Activated Sludge Process
}

Saleh Mohammed Al-Muzaini

University of Rhode Island

Follow this and additional works at: https://digitalcommons.uri.edu/oa_diss

\section{Recommended Citation}

Al-Muzaini, Saleh Mohammed, "Treatment of Refinery Wastewaters Using Various Modified Activated Sludge Process" (1987). Open Access Dissertations. Paper 552.

https://digitalcommons.uri.edu/oa_diss/552

This Dissertation is brought to you for free and open access by DigitalCommons@URI. It has been accepted for inclusion in Open Access Dissertations by an authorized administrator of DigitalCommons@URI. For more information, please contact digitalcommons-group@uri.edu. 
TREATMENT OF REF INERY WASTEWATERS

USING VARIOUS MODIFIED

ACTIVATED SLUDGE PROCESSES

BY

SALEH MOHAMMED AL-MUZAINI

A DISSERTATION SUBMITTED IN PARTIAL FULFILLMENT OF THE REQU IREMENTS FOR THE DEGREE OF DOCTOR OF PHILOSOPHY

IN

CIVIL AND ENVIRONMENTAL ENGINEERING

UNIVERSITY OF RHODE ISLAND

1987 


\section{DOCTOR OF PHILOSOPHY DISSERTATION \\ OF}

SALEH MOHAMMED AL-MUZAINI

Approved:

Dissertation Committee

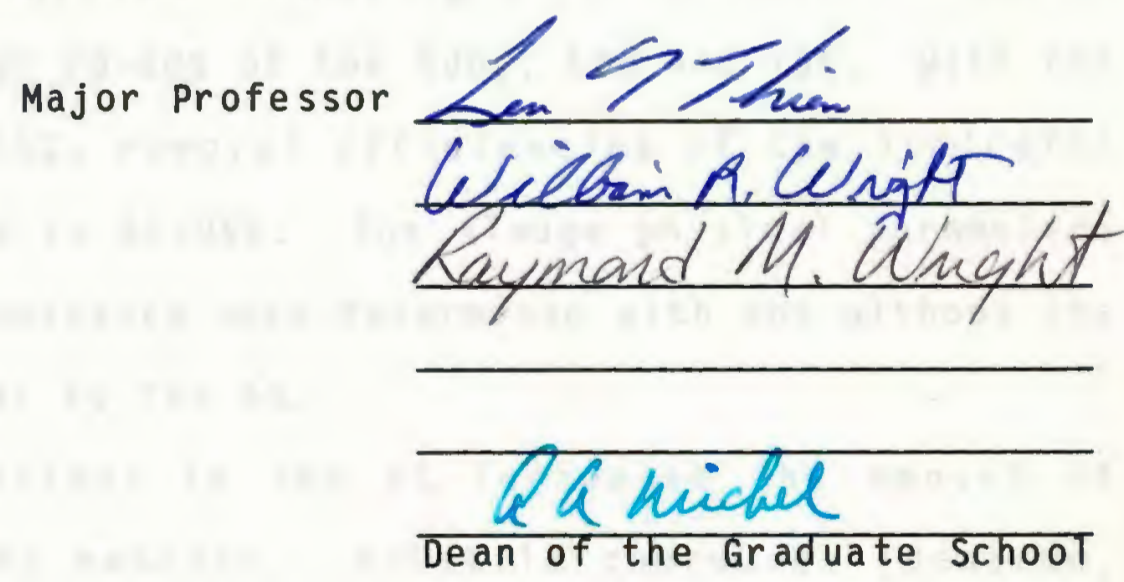




\section{ABSTRACT}

Biological prosesses for treating refinery industry wastewater for re-use were studied. A pilot-scale biological reactor was constructed to simulate the activated sludge treatment process.

Actual refinery industry wastewater collected from a regional refinery and spiked with additions of selected priority organics was fed at a rate of 1.3 liters/hour into a 6-liter pilot plant having a hydraulic retention time of 4 hours. Activated sludge (AS) which was augmented by additions of powdered activated carbon (PAC) at dosages of 10,50 and $120 \mathrm{mg} / \mathrm{L}$ was evaluated. The AS process removed 70-80\% of the $B O D_{5}, C O D$ and TOC. With the addition of PAC, removal efficiencies of the indicator compounds rose to $80-95 \%$. The sludge physical parameters and kinetic constants were determined with and without the addition of PAC to the AS.

$P A C$ additions to the AS increased the amount of biomass in the reactor. Volatile compounds (benzene, chloroform, ethylbenzene, toluene, m-xylene and $0-x y l e n e$ ) were removed from the reactor by volatilization which occurred from air stripping. PAC alone (without AS) was primarily responsible for removing base and acid/neutralextractable compounds (2,4-dimethylphenol, fluorene, naphthalene and pyrene). 


\section{ACKN OWLEDGMENTS}

This investigation was supported by a grant from the Kuwait Environmental Protection Council and the Kuwait Institute for Scientific Research.

The author wishes to extend his appreciation to his advisor, Dr. Leon Thiem and to Dr. Raymond Wright and Dr. William Wright for their assistance. Also the author would like to thank Sam Huston for his help in bringing wastewater from Pennsylvania to Rhode Island, George Huston for assistance with the mechanical apparatus and to my family for their understanding. 
Page

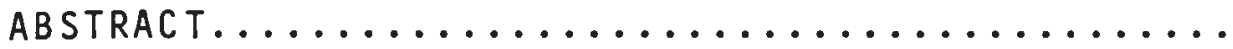

ACKNOWLEDGEMENTS.....................

TABLE OF CONTENTS..................... iv

LIST OF FIGURES.................... viii

LIST OF TABLES..................... xi

GLOSSARY........................ xix

1. INTRODUCTION

1.1 Shuaiba Industrial Area Site Description. 1

1.1.1 Existing Water Quality ........... 6

1.1.2 Present Wastewater Treatment........ 7

1.2 objectives................... 11

2. LITERATURE REVIEW

2.1 Activated Sludge Treatment Processes....

2.2 Addition of Powdered Activated Carbon To Improve Activated Sludge

Treatment....................... 14

2.3 Priority Pollutants............... 29

2.4 Air Stripping.................... 32

2.5 Industrial Wastewater Reclamation and

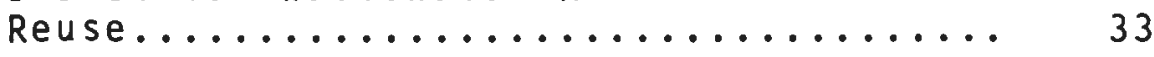

3. EXPERIMENTAL PROCEDURE

3.1 Equipment................... 40

3.2 Experimental steps.............. 43

3.3 Sampling Procedure.............. 51 


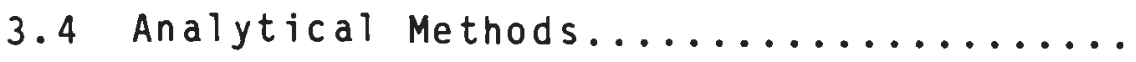

3.4.1 Sample Preparation............ 54

3.5 Seeding Refinery Industry wastewater.... 62

3.6 Start-up of the Biological pilot plant.. 62

4. CHARACTERIZATION OF THE STANDARD REFINERY WASTEWATER

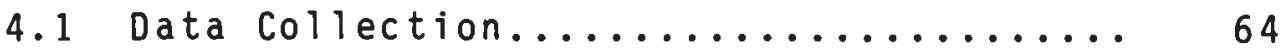

4.2 Selection of Priority Pollutants....... 66

5. PRIORITY ORGANICS REMOVAL PROCESSES

5.1 Activated sludge ................ 71

5.2 Integrated Powdered Activated Carbon

$(P A C)$ and Activated Sludge (AS) ........ 73

5.3 Air Stripping and Adsorption......... 75

5.4 Integrated Powdered Activated

Carbon (PAC) in the Absence of

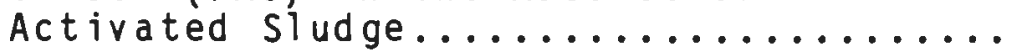

6. BIOLOGICAL ANALYSIS

6.1 Initial Biomass Seeding........... 78

6.2 Biological Model............... 86

6.3 Biokinetic Constants.............. 90

6.4 Determination of Kinetic Coefficients... 93

6.5 Microscopic Analysis of Activated Sludge

6.5.1 Materials and Methods......... 94

6.6 Biogrowth on Powdered Activated

Carbon ( $P A C) \ldots \ldots \ldots \ldots \ldots \ldots \ldots . \ldots . \ldots . \ldots 9$

6.6.1 Materials and Methods......... 95

7. RE SULTS

7.1 Description and Evaluation of

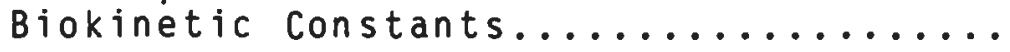


7.2 Experiment 1: Activated sludge

Treatment Process................. 102

7.3 Experiment 2: Activated sludge with

Powdered Activated Carbon............ 123

7.4 Evaluation of Biological Growth in

Experiments 1 and $2 \ldots \ldots \ldots \ldots \ldots \ldots . \ldots \ldots$

7.4.1 Light Microscopic Analysis...... 175

7.4.2 Scanning Electron Microscopic

Analysis................. 186

7.5 Experiment 3: Air Stripping Process.... 193

7.6 Experiment 4: PAC without ACtivated

Sludge........................... 194

,

8. CONCLUSIONS.......................... 210

9. RECOMMENDATIONS..................... 211

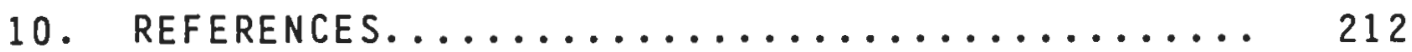

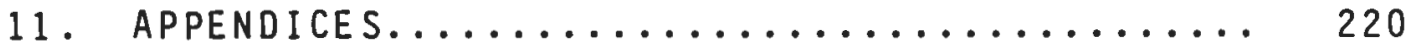

Appendix 1: A List of Priority Pollutants... 221

Appendix 2: Experiment 1: Figures for

Bio-kinetic

Constants........

Appendix 3: Experiment 1: Figures for

Priority

Pollutants

Remoral..........

Appendix 4: Experiment 2: Figures for

Priority

Pollutants

Removal, $\mathrm{PAC}=$

10,50 and 120

$\mathrm{mg} / \mathrm{L} . \ldots \ldots \ldots \ldots$

Appendix 5: Modification of Purgeable

Halocarbons Method 601........ 270

Appendix 6: Modification of Volatile

Aromatics Method $602 \ldots . \ldots \ldots . .275$ 
Appendix 7: Water analysis in the Shuaiba Industrial Area............ 280

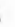




\section{LIST OF FIGURES}

Figure 1.1

Figure 1.2

Figure 3.1 .1

Figure 3.1 .2

Figure 3.1 .3

Figure 3.1 .4

Figure 5.1

Figure 6.1 .1

Figure 6.1 .2

Location of the Shuaiba Industrial Area with Respect to Kuwait City

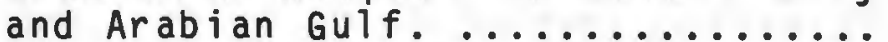

Shuaiba Industrial Area..........

Schematic diagram of the Integrated

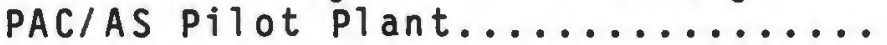

Schematic of the Holding Tank and

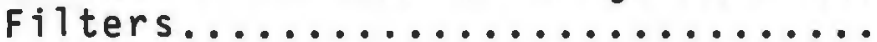

Schematic Diagram of the Experimental Clarifier Unit.......

Schematic Diagram of the Weir

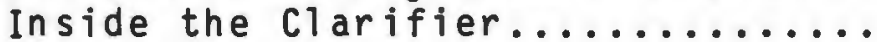

Suspended Solids Concentration in the Reactor Unit................

Aeration Tank Suspended Sol ids Concentration During Activated

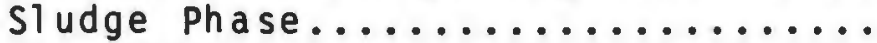

Figure 6.1.3 Areation Tank Suspended Solids,

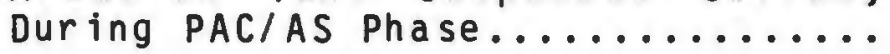

Figure 6.1.4 Clarifier Suspended Solids Effluent During Activated Sludge Phase......

Figure 6.1.5 Clarifier Suspended Solids Effluent During PAC/AS Phase...............

Figure 6.2.1 Complete Mix Activated Sludge Model

Figure 7.2.1 $\quad \mathrm{BOD}_{5}$ Removal by Activated Sludge...

Figure 7.2.2 TOC Removal by Activated S1 udge....

Figure 7.2.3 COD Removal by Activated sludge....

Figure 7.3 .1

$\mathrm{BOD}_{5}$ Removal by Activated Sludge and ${ }^{5}$ Powdered Activated Carbon, PAC

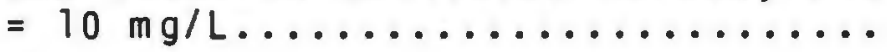


Figure 7.3.2 $\quad \mathrm{BOD}_{5}$ Removal by Activated Sludge and Powdered Activated Carbon PAC $=50$

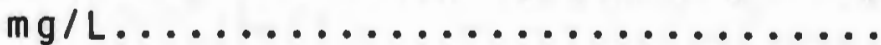

Figure 7.3.3 $\mathrm{BOD}_{5}$ Removal by Activated Sludge and Powdered Activated Carbon PAC $=120$ $\mathrm{mg} / \mathrm{L} \ldots \ldots \ldots \ldots \ldots \ldots \ldots \ldots \ldots \ldots \ldots$

Figure 7.3.4 Effect of Sludge Age on $\mathrm{BOD}_{5}$ Removal 146

Figure 7.3.5 COD Removal by Activated Sludge and Powdered Activated Carbon PAC $=10$ $\mathrm{mg} / \mathrm{L} \ldots \ldots \ldots \ldots \ldots \ldots \ldots \ldots \ldots \ldots \ldots$

Figure 7.3.6 COD Removal by Activated Sludge and Powdered Activated Carbon PAC $=50$ $\mathrm{mg} / \mathrm{L} \ldots \ldots \ldots \ldots \ldots \ldots \ldots \ldots \ldots \ldots$

Figure 7.3.7 COD Removal by Activated Sludge and Powdered Activated Carbon PAC = $120 \mathrm{mg} / \mathrm{L} \ldots \ldots \ldots \ldots \ldots \ldots \ldots \ldots \ldots$

Figure 7.3.8 Effect of Sludge Age on COD Removal 151

Figure 7.3.9 TOC Removal by Activated Sludge and Powdered Activated Carbon PAC $=10$ $\mathrm{mg} / \mathrm{L} \ldots \ldots \ldots \ldots \ldots \ldots \ldots \ldots \ldots \ldots$

Figure 7.3.10 TOC Removal by Activated Sludge and Powdered Activated Carbon PAC $=50$ $\mathrm{mg} / \mathrm{L} \ldots \ldots \ldots \ldots \ldots \ldots \ldots \ldots \ldots \ldots$

Figure 7.3.11 TOC Removal by Activated Sludge and Powdered Activated Carbon PAC =

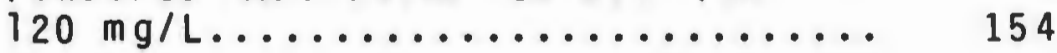

Figure 7.3.12 Effect of Sludge Age on TOC Removal 155

Figure 7.4.1.1 Photomicrograph of protozoa in a raw aerated wastewater $(160 x)$.

Figure 7.4.1.2 Photomicrograph of filamentous floc (bacteria) in the activated sludge $(160 x) \ldots \ldots \ldots \ldots \ldots \ldots \ldots$

Figure 7.4.1.3 Photomicrograph of filamentous microorganisms (bacteria) in the activated sludge $(160 x) \ldots \ldots \ldots \ldots$ 
Figure 7.4.1.4 Photomicrograph of a ciliate microorganism in the activated sludge $(160 x) \ldots \ldots \ldots \ldots \ldots \ldots \ldots$

Figure 7.4.1.5 Photomicrograph of a ciliate in the activated sludge $(160 \mathrm{x}) \ldots \ldots \ldots$

Figure 7.4.1.6 Photomicrograph of a rotifier in the activated sludge $(160 x) \ldots \ldots$.

Figure 7.4.1.7 Photomicrograph of dispersed bacteria in the activated sludge

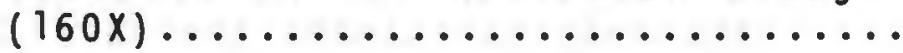

Figure 7.4.1.8 Changing Microorganism Population

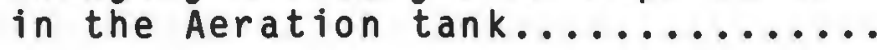

Figure 7.4.2.1 Scanning electron micrograph of the surface of virgin PAC particles without biological growth..........

Figure 7.4.2.2 Scanning electron micrograph of PAC particles exposed to refinery industry wastewater for 44 days (rod-shaped bacteria were attached, PAC dosage $120 \mathrm{mg} / \mathrm{L}$,

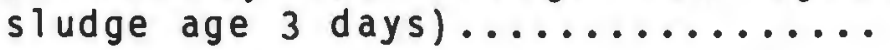

Figure 7.4.2.3 Scanning electron micrograph of PAC particles exposed to refinery industry wastewater for 44 days (rod-shaped bacteria are present in the wastewater, PAC dosage 120

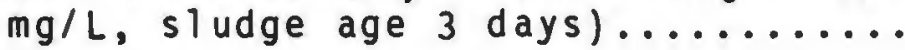

Figure 7.4.2.4 Scanning electron micrograph of PAC particles exposed to refinery industry wastewater for 56 days in a complete mixed reactor, (rodshaped bacteria are growing on the PAC particles, PAC dosage $120 \mathrm{mg} / \mathrm{L}$ sludge age 12 days) $\ldots \ldots \ldots \ldots \ldots \ldots$

Figure 7.4.2.5 Scanning electron micrograph of PAC particles exposed to refinery industry wastewater for 56 days in a complete mixed reactor with 120 $\mathrm{mg} / \mathrm{L}$ of carbon, (rod-shaped bacteria are growing on PAC

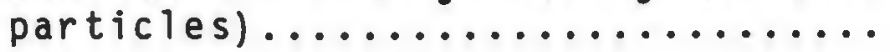


Figure 7.6.1 A comparison of COD Removal by PAC and $P A C / A S \ldots . . . \ldots . . . . . . . . .200$

Figure 7.6.2 A comparison of TOC Removal by PAC and PAC/AS..................... 201

Figure 7.6.3 2,4-Dimethylphenol Removal by Powdered Activated Carbon.......... 205

Figure 7.6.4 Fluorene Removal by Powdered Activated Carbon............... 206

Figure 7.6.5 Naphthalene Removal by Powdered Activated Carbon............... 207

Figure 7.6.6 Pyrene Removal by Powdered Activated Carbon....................... 208 


\section{LIST OF TABLES}

Table 1.1

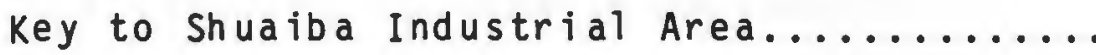

Table 1.1.1 Industrial Wastewater Flows and Pollution Loads in the SIA (Source: Ref. No. 58)..... 8

Table 1.1.2 Recommended Ambient Marine Environment Quality Criteria for Inshore Waters

Around Shuaiba (Source: Ref. No. 58)..... 10

Table 3.1.1 Physical Properties of the BL type of Powdered Activated Carbon (Calgon Corporation, Pittsburgh, PA) ........... 46

Table 3.2.1 Operating Conditions of the Biological

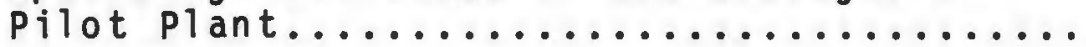

Table 3.2. 2 Characteristics of the Refinery Industry Wastewater....................... 49

Table 3.2.3 Chemical Composition of the Refinery Industry Wastewater Treated by the Pilot Plant.

Table 3.3.1 Sampling and Analytical Work Schedule for the Biological Treatment Pilot Plant....... 52

Table 3.4.1.1 Tekmar Model LSC-2 Conditions for Analysis

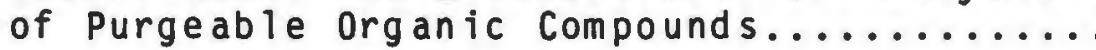

Table 3.4.1.2 Gas Chromatographic Conditions for

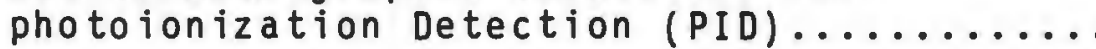

Table 3.4.1.3 Gas Chromatographic Conditions for Hall

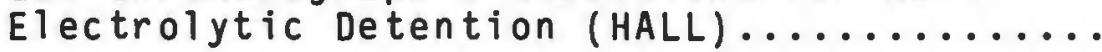

Table 3.4.1.4 Gas Chromatographic Conditions for Flame

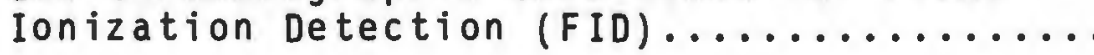

Table 4.1 .1

Results of Analysis for the Composite Samples From the KNPC - API Separator and

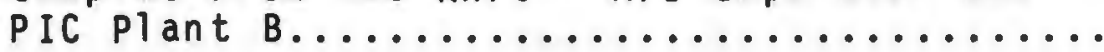

Table 4.1.2 Extractable Organic Compounds Found in KNPC API Effluent

Table 4.1.3 Halocarbon and Aromatic Compound Concentrations Found in Wastewater of KNPC

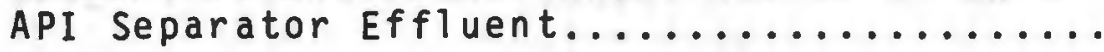


Table 4.2 .1

Chemical and Physical Characteristics of Selected Priority Organic Pollutants....... 70

Table 7.1.1 Biokinetic Constants for the Modified Activated sludge Pilot Plant ............ 99

Table 7.1.2 Typical Values for Biokinetic Constants for the Activated Sludge at $20^{\circ} \mathrm{C}$ (Ref.

no. 48)........................... 100

Table 7.2.1 Biological Treatment of Refinery Industry Wastewater by Activated Sludge, Sludge Age $\left(\theta_{c}\right)=3$ days, (A11 concentrations are in

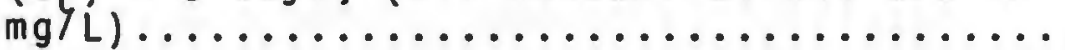

Table 7.2.2 Biological Treatment of Refinery Industry Wastewater by Activated Sludge, Sludge Age $\left(\theta_{c}\right)=6$ days, (All concentrations are in

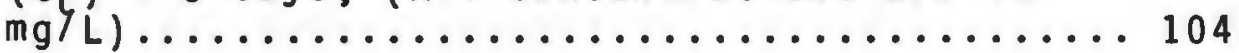

Table 7.2.3 Biological Treatment of Refinery Industry Wastewater by Activated Sludge, Sludge Age $\left(\theta_{C}\right)=9$ days, (A11 concentrations are in

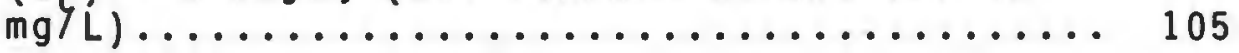

Table 7.2.4 Biological Treatment of Refinery Industry Wastewater by Activated Sludge. Sludge Age $\left(\theta_{c}\right)=12$ days, (All concentrations are in $\mathrm{mg} / L)$

Table 7.2.5 Activated Sludge Performance in Experiment

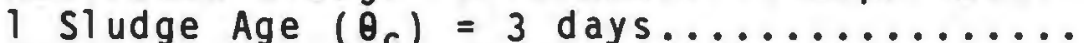

Table 7.2.6 Activated Sludge Performance in Experiment

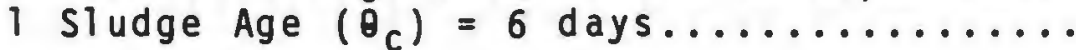

Table 7.2.7 Activated Sludge Performance in Experiment

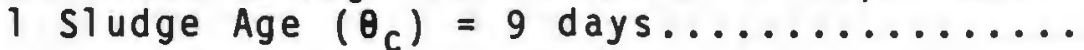

Table 7.2.8 Activated Sludge Performance in Experiment 1 Sludge Age $\left(\theta_{c}\right)=12$ days.............. 109

Table 7.2.9 Priority Pollutants Removal by Activated Sludge, Sludge Age $\left(\theta_{c}\right)=3$ days.......... 114

Table 7.2.10 Priority Pollutants Removal by Activated

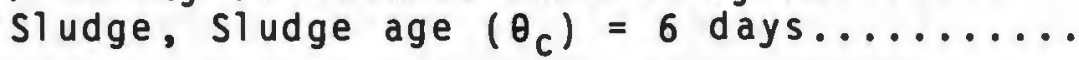

Table 7.2.11 Priority Pollutants Removal by Activated Sludge, Sludge Age $\left(\theta_{c}\right)=9$ days......... 116 
Table 7.2.12 Priority Pollutants Removal by Activated Sludge, Sludge Age $\left(\theta_{c}\right)=12$ days.........................

Table 7.2 .13 Volatile Organics Removal by Activated Sludge Treatment, Sludge Age $\left(\theta_{c}\right)=3$

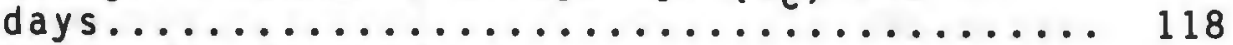

Table 7.2.14 Volatile Organics Removal by Activated Sludge Treatment, Sludge Age $\left(\theta_{C}\right)=6$ days.. 119

Table 7.2.15 Volatile Organics Removal by Activated Sludge Treatment, Sludge Age $\left(\theta_{C}\right)=9$ days.. 120

Table 7.2.16 Volatile Organics Removal by Activated Sludge Treatment, Sludge Age $\left(\theta_{C}\right)=12$ days. 121

Table 7.3.1 Activated Sludge and PAC Performances in Experiment 2 when $\theta_{C}=3$ days and $P A C=10$ $\mathrm{mg} / \mathrm{L}, \mathrm{All}$ Concentrations are in $\mathrm{mg} / \mathrm{L} \ldots \ldots . . .124$

Table 7.3.2 Activated Sludge and PAC Performances in Experiment 2 when $\theta_{C}=6$ days and $P A C=10$ $\mathrm{mg} / \mathrm{L}, \mathrm{All}$ Concentrations are in $\mathrm{mg} / \mathrm{L} \ldots \ldots . .125$

Table 7.3.3 Activated Sludge and PAC Performances in Experiment 2 when $\theta_{C}=9$ days and $P A C=10$ $\mathrm{mg} / \mathrm{L}, \mathrm{A} 11$ Concentrations are in $\mathrm{mg} / \mathrm{L} \ldots \ldots \ldots 126$

Table 7.3.4 Activated Sludge and PAC Performances in Experiment 2 when $\theta_{C}=12$ days and $P A C=10$ $\mathrm{mg} / \mathrm{L}, \mathrm{All}$ Concentrations are in $\mathrm{mg} / \mathrm{L} \ldots . . .$. .

Table 7.3.5 Activated Sludge and PAC Performances in Experiment 2 when $\theta_{C}=3$ days and $P A C=50$ $\mathrm{mg} / \mathrm{L}$, All Concentrations are in $\mathrm{mg} / \mathrm{L} \ldots \ldots . .128$

Table 7.3.6 Activated Sludge and PAC Performances in Experiment 2 when $\theta_{C}=6$ days and

$P A C=50 \mathrm{mg} / \mathrm{L}$, all Concentrations are in

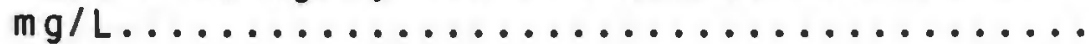

Table 7.3.7 Activated Sludge and PAC Performances in Experiment 2 when $\theta_{C}=9$ days and $P A C=50$ $\mathrm{mg} / \mathrm{L}, \mathrm{A} 1 \mathrm{l}$ Concentrations are in $\mathrm{mg} / \mathrm{L} \ldots \ldots . .130$

Table 7.3.8 Activated Sludge and PAC Performances in Experiment 2 when $\theta_{C}=12$ days and $P A C=50$ $\mathrm{mg} / \mathrm{L}, \mathrm{A} 11$ Concentrations are in $\mathrm{mg} / \mathrm{L} \ldots . . .$. 
Table 7.3.9 Activated Sludge and PAC Performances in Experiment 2 when $\theta_{C}=3$ days and $P A C=120$ $\mathrm{mg} / \mathrm{L}, \mathrm{All}$ Concentrations are in $\mathrm{mg} / \mathrm{L} \ldots . . .$. .

Table 7.3.10 Activated Sludge and PAC Performances in Experiment 2 when $\theta_{C}=6$ days and $P A C=120$ $\mathrm{mg} / \mathrm{L}, \mathrm{A} 11$ Concentrations are in $\mathrm{mg} / \mathrm{L} \ldots . . .$. .

Table 7.3.11 Activated Sludge and PAC Performances in Experiment 2 when $\theta_{C}=9$ days and $P A C=120$ $\mathrm{mg} / \mathrm{L}, \mathrm{A} 11$ Concentrations are in $\mathrm{mg} / \mathrm{L} \ldots \ldots . .134$

Table 7.3.12 Activated S1 udge and PAC Performances in Experiment 2 when $\theta_{C}=12$ days and $P A C=120$ $\mathrm{mg} / \mathrm{L}$, All Concentrations are in $\mathrm{mg} / \mathrm{L} \ldots . . .$.

Table 7.3.13 $\mathrm{BOD}_{5}, \mathrm{COD}$, and TOC Removals in Experiment 2 when $\theta_{C}=3$ days and $P A C=10 \mathrm{mg} / \mathrm{L} \ldots \ldots \ldots \ldots$

Table 7.3.14 $\mathrm{BOD}_{5}, \mathrm{COD}$ and TOC Removals in Experiment 2 when $\theta_{C}=6$ days and $P A C=10 \mathrm{mg} / \mathrm{L} \ldots \ldots \ldots$

Table 7.3.15 $\mathrm{BOD}_{5}, \mathrm{COD}$ and TOC Removals in Experiment 2 when $\theta_{C}=9$ days and $P A C=10 \mathrm{mg} / \mathrm{L} \ldots \ldots \ldots 138$

Table 7.3.16 $\mathrm{BOD}_{5}, \mathrm{COD}$ and TOC Removals in Experiment 2 when $\theta_{C}=12$ days and $P A C=10 \mathrm{mg} / \mathrm{L} \ldots \ldots \ldots$

Table 7.3.17 $\mathrm{BOD}_{5}, \mathrm{COD}$ and TOC Removals in Experiment 2 when ${ }{ }_{C}=3$ days and $P A C=50 \mathrm{mg} / \mathrm{L} \ldots \ldots \ldots$.

Table 7.3.18 $\mathrm{BOD}_{5}, \mathrm{COD}$ and TOC Removals in Experiment 2 when $\theta_{C}=6$ days and $P A C=50 \mathrm{mg} / \mathrm{L} \ldots \ldots \ldots 139$

Table 7.3.19 $\mathrm{BOD}_{5}, \mathrm{COD}$ and TOC Removals in Experiment 2 when $\theta_{C}=9$ days and $P A C=50 \mathrm{mg} / \mathrm{L} \ldots \ldots \ldots .140$

Table 7.3.20 $\mathrm{BOD}_{5}, \mathrm{COD}$ and TOC Removals in Experiment 2 when $\theta_{C}=12$ days and $P A C=50 \mathrm{mg} / \mathrm{L} \ldots \ldots \ldots$

Table 7.3.21 $\mathrm{BOD}_{5}, \mathrm{COD}$ and TOC Removals in Experiment 2 when $\theta_{C}=3$ days and $P A C=120 \mathrm{mg} / \mathrm{L} \ldots \ldots \ldots$

Table 7.3.22 $\mathrm{BOD}_{5}, \mathrm{COD}$ and TOC Removals in Experiment 2 when $\theta_{C}=6$ days and $P A C=120 \mathrm{mg} / \mathrm{L} \ldots \ldots \ldots 141$

Table 7.3.23 $\mathrm{BOD}_{5}, \mathrm{COD}$ and TOC Removals in Experiment 2 when $\theta_{C}=9$ days and $P A C=120 \mathrm{mg} / \mathrm{L} \ldots \ldots \ldots 142$

Table 7.3.24 $\mathrm{BOD}_{5}, \mathrm{COD}$ and TOC Removals in Experiment 2 when $\theta_{C}=12$ days and $P A C=120 \mathrm{mg} / \mathrm{L} \ldots \ldots \ldots$ 
Table 7.3.25 Priority Pollutants Removal, Experiment 2 when $\theta_{C}=3$ days and $P A C=10 \mathrm{mg} / \mathrm{L} \ldots \ldots \ldots 156$

Table 7.3.26 Priority Pollutants Removal, Experiment 2 when $\theta_{C}=6$ days and $P A C=10 \mathrm{mg} / \mathrm{L} \ldots \ldots \ldots 156$

Table 7.3.27 Priority Pollutants Removal, Experiment 2 when $\theta_{C}=9$ days and $P A C=10 \mathrm{mg} / \mathrm{L} \ldots \ldots \ldots . .157$

Table 7.3.28 Priority Pollutants Removal, Experiment 2 when $\theta_{C}=12$ days and $P A C=10 \mathrm{mg} / \mathrm{L} \ldots \ldots \ldots$

Table 7.3.29 Priority Pollutants Removal, Experiment 2 when $\theta_{C}=3$ days and $P A C=50 \mathrm{mg} / \mathrm{L} \ldots \ldots \ldots 158$

Table 7.3.30 Priority Pollutants Removal, Experiment 2 when $\theta_{c}=6$ days and $P A C=50 \mathrm{mg} / \mathrm{L} \ldots \ldots \ldots 158$

Table 7.3.31 Priority Pollutants Removal, Experiment 2 when $\theta_{c}=9$ days and $P A C=50 \mathrm{mg} / \mathrm{L} \ldots \ldots \ldots 159$

Table 7.3.32 Priority Pollutants Removal, Experiment 2 when $\theta_{C}=12$ days and $P A C=50 \mathrm{mg} / \mathrm{L} \ldots \ldots \ldots 159$

Table 7.3.33 Priority Pollutants Removal, Experiment 2 when $\theta_{C}=3$ days and $P A C=120 \mathrm{mg} / \mathrm{L} \ldots \ldots \ldots 160$

Table 7.3.34 Priority Pollutants Removal, Experiment 2 when $\theta_{C}=6$ days and $P A C=120 \mathrm{mg} / \mathrm{L} \ldots \ldots \ldots 160$

Table 7.3.35 Priority Pollutants Removal, Experiment 2 when $\theta_{C}=9$ days and $P A C=120 \mathrm{mg} / \mathrm{L} \ldots \ldots \ldots 161$

Table 7.3.36 Priority Pollutants Removal, Experiment 2 when $0_{C}=12$ days and $P A C=120 \mathrm{mg} / \mathrm{L} \ldots \ldots \ldots 161$

Table 7.3.37 Volatile Organics Removal, Experiment 2 when

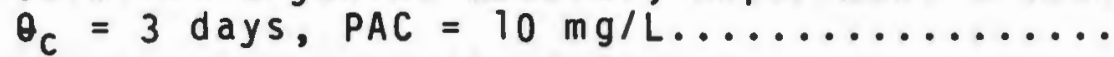

Table 7.3.38 Volatile Organics Removal, Experiment 2 when

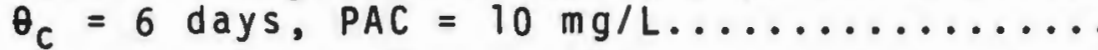

Table 7.3.39 Volatile Organics Removal, Experiment 2 when

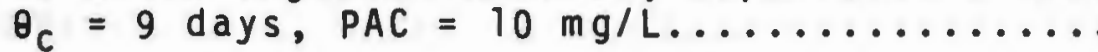
165

Table 7.3.40 Volatile Organics Removal, Experiment 2 when

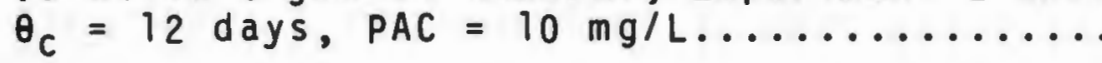

Table 7.3.41 Volatile Organics Removal, Experiment 2 when $\theta_{c}=3$ days, $P A C=50 \mathrm{mg} / \mathrm{L} \ldots \ldots \ldots \ldots \ldots \ldots$ 
Table 7.3.42 Volatile Organics Removal, Experiment 2 when $\theta_{C}=6$ days, $P A C=50 \mathrm{mg} / \mathrm{L} \ldots \ldots \ldots \ldots \ldots \ldots 168$

Table 7.3.43 Volatile Organics Removal, Experiment 2 when $\theta_{C}=9$ days, $P A C=50 \mathrm{mg} / \mathrm{L} \ldots \ldots \ldots \ldots \ldots \ldots$.

Table 7.3.44 Volatile Organics Removal, Experiment 2 when $\theta_{c}=12$ days, $P A C=50 \mathrm{mg} / \mathrm{L} \ldots \ldots \ldots \ldots \ldots \ldots$

Table 7.3.45 Volatile Organics Removal, Experiment 2 when

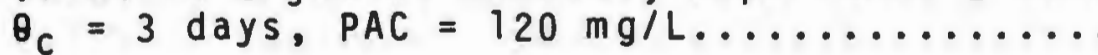

Table 7.3.46 Volatile Organics Removal, Experiment 2 when $\theta_{C}=6$ days, $P A C=120 \mathrm{mg} / \mathrm{L} \ldots \ldots \ldots \ldots \ldots \ldots$.

Table 7.3.47 Volatile Organics Removal, Experiment 2 when $\theta_{C}=9$ days, $P A C=120 \mathrm{mg} / \mathrm{L} \ldots \ldots \ldots \ldots \ldots \ldots 173$

Table 7.3. 48 Volatile Organics Removal Experiment 2 when ${ }^{\theta_{C}}=12$ days, $P A C=120 \mathrm{mg} / \mathrm{L} \ldots \ldots \ldots \ldots \ldots \ldots 174$

Table 7.5.1 Percent Stripping of Volatile Compounds in Nonbiological system, Experiment 3 , air flow rate $=300 \mathrm{ml} / \mathrm{min} / \mathrm{L} \ldots \ldots \ldots \ldots \ldots \ldots \ldots \ldots \ldots$

Table 7.5.2 Percent Stripping of Volatile Compounds in Nonbiological system, Experiment 3, air flow rate $=400 \mathrm{ml} / \mathrm{min} / \mathrm{L} \ldots \ldots \ldots \ldots \ldots \ldots \ldots \ldots . . . .196$

Table 7.5.3 Percent Stripping of Volatile Compounds in Nonbiological System, Experiment 3, air flow

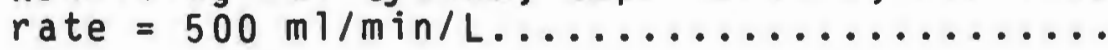

Table 7.6.1 COD and TOC Removal Efficiencies in Experiment 4 , When $P A C=10 \mathrm{mg} / \mathrm{L} \ldots \ldots \ldots \ldots . .199$

Table 7.6.2 COD and TOC Removal Efficiencies in Experiment 4 , When $P A C=50 \mathrm{mg} / \mathrm{L} \ldots \ldots \ldots \ldots 199$

Table 7.6.3 COD and TOC Removal Efficiencies in Experiment 4 , When $P A C=120 \mathrm{mg} / \mathrm{L} \ldots \ldots \ldots \ldots$

Table 7.6.4 Priority Organic Pollutants' Removal Efficiencies in Experiment 4 , when $P A C=10$

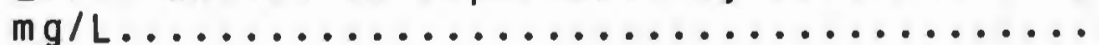

Table 7.6.5 Priority Organic Pollutants' Removal Efficiencies in Experiment 4 , when PAC $=50$

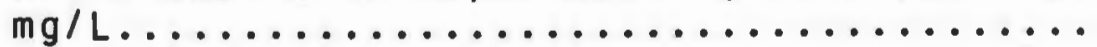


Table 7.6.6 Priority Organic Pollutants' Removal

Efficiencies in Experiment 4 , when $P A C=120$

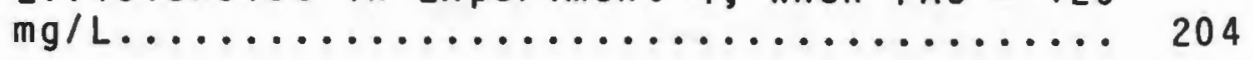

Table 7.6.7 Volatile Compounds Removal Efficiencies in

Experiment 4 , when $P A C=10 \mathrm{mg} / \mathrm{L} \ldots \ldots \ldots . . .204$

Table 7.6.8 Volatile Compounds Removal Efficiencies in Experiment 4 , when $P A C=50 \mathrm{mg} / \mathrm{L} \ldots \ldots \ldots 209$

Table 7.6.9 Volatile Compounds Removal Efficiencies in

Experiment 4 , when $P A C=120 \mathrm{mg} / \mathrm{L} \ldots \ldots \ldots . .209$ 


\section{GLOSSARY}

AAS Atomic adsorption spectrophotometry

AS Activated Sludge

API American Petroleum Institute

$\mathrm{BOD}_{5}$ Biochemical oxygen demand, $\mathrm{mg} / \mathrm{L}$

C Equilibrium carbon concentration, $\mathrm{mg} / \mathrm{L}$

$c_{I}$ Influent carbon concentration, $\mathrm{mg} / \mathrm{L}$

COD Chemical oxygen demand, $\mathrm{mg} / \mathrm{L}$

D Dajly carbon dosage, $\mathrm{mg} / \mathrm{L}$

DOC Dissolved organic carbon, $\mathrm{mg} / \mathrm{L}$

Efft Effluent, concentration, ug/L

Effy Efficiency of the system

EPA U.S. Environmental Protection Agency

EPC Kuwait Environmental Protection Council

EPC Environmental Protection Center

GC Gas Chromatography

GPM Gallon per minute, GPM

HDT Hydraulic detention time, hours

HRT Hydraulic retention time, hours

Inft Influent, concentration, ug/L

k Maximum rate of substrate utilization, day-1

$k_{d}$ Endogenous decay coefficient, day-1

$\mathrm{K}_{S} \quad \mathrm{Half}$ velocity constant, $\mathrm{mg} / \mathrm{L}$ of $\mathrm{BOD}_{5}$ or $\mathrm{COD}$

KNPC Kuwait National Petroleum Company

MGD Milliongallons per day, MGD 
MLSS Mixed liquor suspended solids, $\mathrm{mg} / \mathrm{L}$

MLVSS Mixed liquor volatile suspended solids, $\mathrm{mg} / \mathrm{L}$

N Number of reactors

PAC Powdered activated carbon

pH Reciprocal of the Logarithm of the Hydrogen Ion Concentration

PIC Petroleum Industrial Companies

Q Flow rate, L/ hr

Qu Effluent flow rate, L/hr

$Q_{0}$ Influent flow rate, L/hr

$a_{r}$ Return flow rate, L/hr

$Q_{u} \quad$ under flow rate, L/hr

$Q_{\text {w }} \quad$ Sludge wasting flow rate, L/ hr

$r_{g}^{\prime} \quad$ Net growth rate of biomass, mg/L

$r_{g} \quad$ Rate of bacterial growth, mg/L day

$r_{\text {sue }}$ Substrate utilization rate, $\mathrm{mg} / \mathrm{L}$

$S$ Substrate concentration, $\mathrm{mg} / \mathrm{L}$

$\mathrm{S}_{\mathrm{e}}$ Effluent substrate concentration, $\mathrm{mg} / \mathrm{L}$

$S_{0} \quad$ Influent substrate concentration, $\mathrm{mg} / \mathrm{L}$

SAA Shuaiba Area Authority

SEM Scanning Electron Microscopy

SIA Shuaiba Industrial Area

SRT Sludge retention time, days

$\mathrm{S}_{r} \quad$ Return cell concentration, $\mathrm{mg} / \mathrm{L}$

$\mathrm{S}_{u} \quad$ Underflow substrate concentration, $\mathrm{mg} / \mathrm{L}$

SS Suspended solids concentration, $\mathrm{mg} / \mathrm{L}$

$x x$ 
$t \quad$ Number of days

TDS Total dissolved solids, $\mathrm{mg} / \mathrm{L}$

TKN Total Kjeldahl nitrogen

TOC Total organic carbon, $\mathrm{mg} / \mathrm{L}$

TSS Total suspended solids, $\mathrm{mg} / \mathrm{L}$

$u^{\prime} \quad$ Net specific growth rate, day-1

$u$ Specific growth rate, day-1

U Specific substrate utilization rate, $\mathrm{gm} / \mathrm{gm}-\mathrm{day}$

$u_{m} \quad$ Maximum specific growth rate, day-1

$v$ volume, $L$

vss volatile suspended solids, $\mathrm{mg} / \mathrm{L}$

WWight of carbon, mg

$x \quad$ Concentration of cells, $\mathrm{mg} / \mathrm{L}$

$x_{e} \quad B i o m a s s$ concentration in the effluent, $\mathrm{mg} / \mathrm{L}$

$x_{0} \quad$ Biomass concentration in the influent, $\mathrm{mg} / \mathrm{L}$

$X_{r} \quad$ Return cell concentration, $\mathrm{mg} / \mathrm{L}$

$x_{u}$ Biomass concentration in the underflow, $\mathrm{mg} / \mathrm{L}$

$X_{W} \quad$ Wasting cell concentration, $\mathrm{mg} / \mathrm{L}$

$Y$ Maximum growth yield, mg VSS/mg-BOD 5 or $C O D$

$\theta_{C} \quad S T u d g e$ age, days

$\theta_{h}$ Hydraulic retention time, hours 


\section{INTRODUCTION}

The Shuaiba Industrial Area (SIA) is Kuwait's first and largest industrial complex and one of the largest industrial areas in the Arabian Gulf. It produces about 6 MGD of refinery industry wastewater which is discharged directly to the Arabian Gulf without extensive treatment.

1.1 Shuaiba Industrial Area Site Description

Shuaiba Industrial Area (SIA) is located about $50 \mathrm{~km}$ south of Kuwait City, Kuwait as shown in Figure 1.1. The total area of SIA (both its Eastern and Western Sectors) is about $22.98 \mathrm{million} s q$. meters. This study focuses only on the Eastern sector. Figure 1.2 presents the Shuabia Industrial Area. The Eastern sector of the SIA has twelve major industries, including a petrochemical company, two refineries, two desalination power plants, a melamine company, an industrial gas corporation, a paper products company, two steam electricity generating stations in addition to several other industries. The key to figure 1.2, which represents the industry locations, is presented in Table 1.1 . 


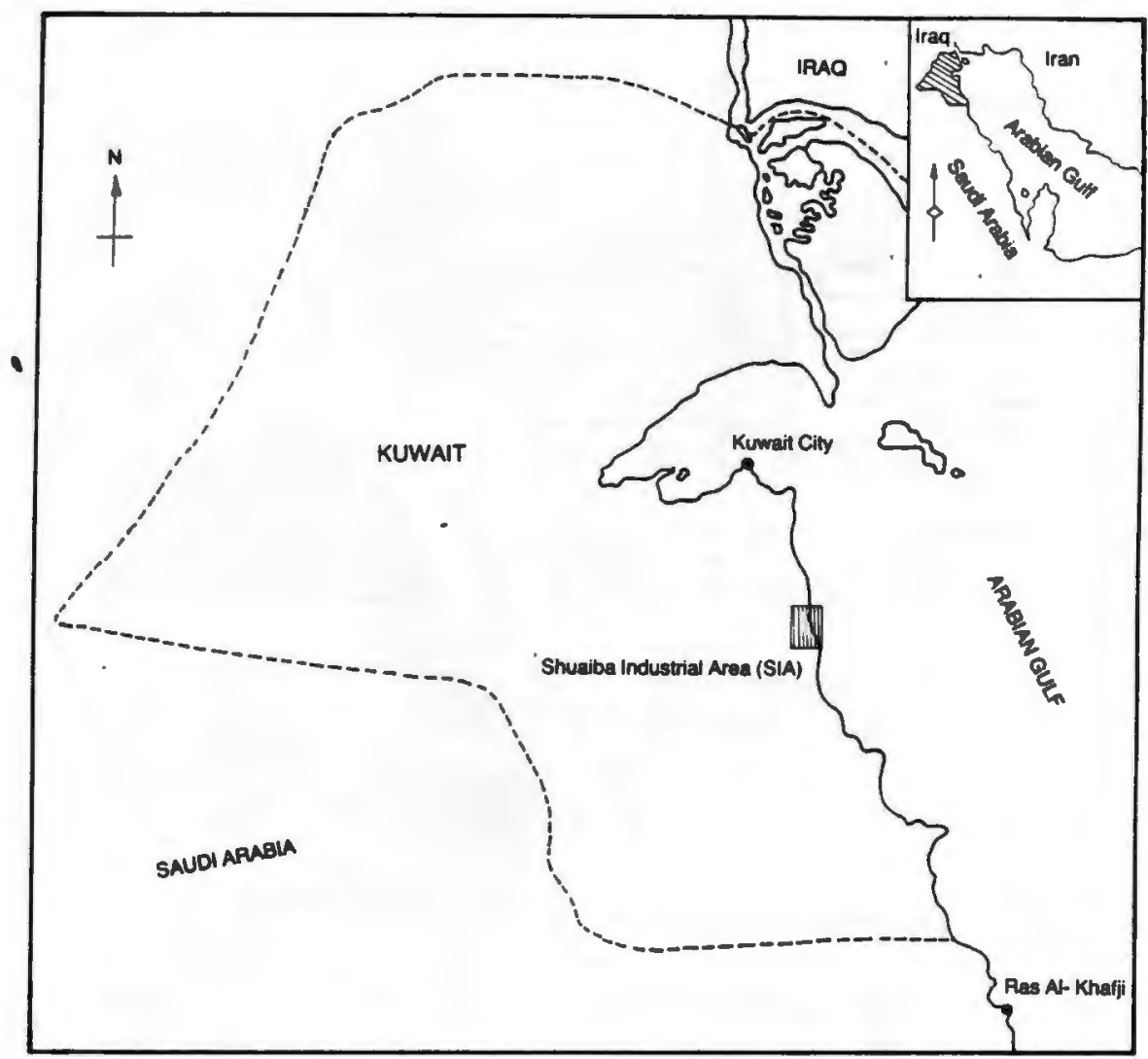

Figure 1.1 Location of the Shuaiba Industrial Area with Respect to Kuwait City and Arabian Gulf 


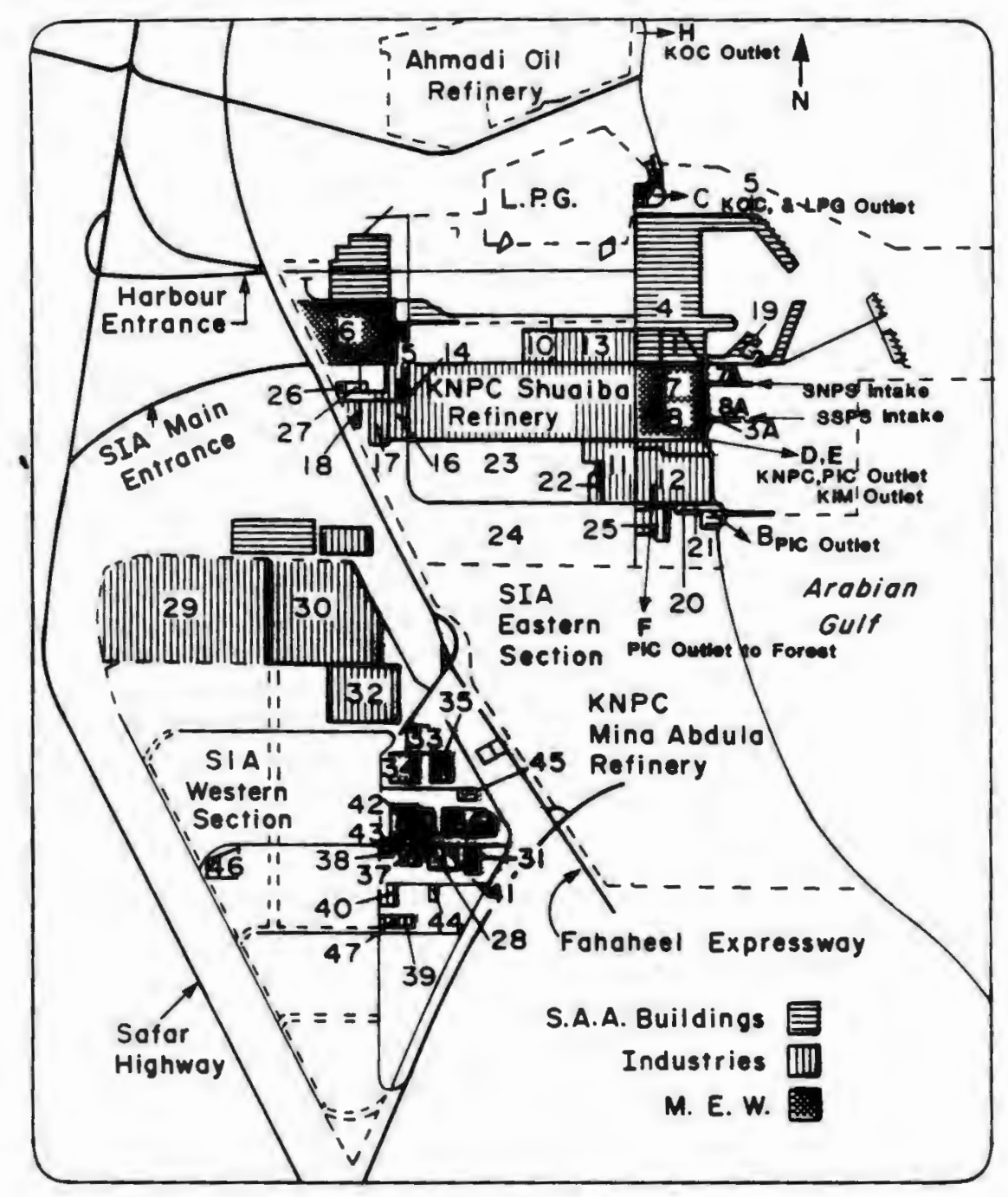

Figure 1.2 Shuaiba Industrial Area 
Table 1.1 Key to Shuaiba Industrial Area

Key No.

Description

\section{EASTERN SECTION}

1 - S.A.A. Buildings

2 - Barge Harbour

3 - Cooling Water Intakes and Pumping Station A,B,C

4 - Environment Protection Center

5 - Shuaiba Harbour Expansion Project

6 - Ministry of Electricity and Water

7 - Shuaiba North Power and Water Production Station

8 - Shuaiba South Power and Water Production Station

9 - K.N.P.C. (Shuaiba Refinery)

10- K.N.P.C. (Lube $0 i l$ Blending Plant)

11-P.I.C. (Fertilizer Division, Plant A)

12-P.I.C. (Fertilizer Division, Plant B)

13- Kuwait Cement Company

14 - Shuaiba Paper Products Company S.A.K.

15- Packaging and Plastic Industries Company.

16- Dresser (Kuwait) S.A.K.

17 - KREMENCO

18- Kuwait Petrochemical Products Co. (Sulphur Factory)

19- United Fisheries of Kuwait Co. Corporation

20- Kuwait Industrial Gases Corporation

21- Refrigeration and oxygen Co. Ltd.

22- Kuwait Melamine Industries Company

23- Proposed Site of Aromatics Project Plant

24- Proposed Site of 0lefins Project Plant

25- Salt \& Chlorine Division

26 - Shuaiba Post office

27 - Industrial Medical Centre 
Table 1.1 (continued) Key to Shuaiba Industrial Area

Key No. Description

\section{WESTERN SECTION}

28- The Gulf Paper Manufacturing Co.

29- N.I.C. (Sand Quarry)

30- N.I.C. Lime Products Factory

31- Kuwait Insulating Material Manufacturing Co.

32- Kuwait Asbestos \& Plastic Industries (N.I.C)

33- Sanitary Ware Company

34 - Kuwaif Precast system Co.

35- Real Estate Con. and Fabrication Co.

36- Kirby Building Systems, Kuwait.

37- Al-Rabiah International Contracting Co.

38- Kuwait Gypsum Manufacturing \& Trading Co.

39- Kuwait Blanket Manufacturing Co.

40- Kuwait Chemical Manufacturing Company

$41-$ Gulf Glass Manufacturing Co.

42- National Automotive Manufacturing \& Trading Co.

43- The Kuwait-Italian Steel structures Co.

44- Kuwait Lube 0 il Co.

45- The Kuwait Desalination Plants Fabrication Co.

46- Kuwait 0il Tanker Company

47 - Kuwait Silicone Products Company 


\subsubsection{Existing Water Quality}

Most of the industries in SIA are located near the shore of the Arabian Gulf, and discharge their wastewater directly into the Gulf after partial treatment or without any treatment. The pollutants remain in the water and because the seawater intakes of the two desalination plants (7A and $8 \mathrm{~A}$ in Figure 1.2) are close to the outlet of these industries ( $B, C, D$, and $E$ in Figure 1.2), the pollutants may enter the water intakes of the desalination plants.

The inshore water of SIA is very shallow. The water depth offshore of SIA averages about 5 meters within $1 \mathrm{~km}$ from the coast line. Thus, most discharged pollutants are not well mixed or diluted with sea water (58).

The discharged industrial wastewaters in the SIA inshore water are diluted with seawater from the cooling water from the pumping stations. The concentration of pollutants in the wastewater will be affected by mixing with seawater in that the concentrations are reduced but the mass loading of the organic pollutants will not be reduced.

The main pollutants discharged by the existing industries in the SIA include the following: a high concentration of ammonia, heavy metals such as chromium, highly-colored wastes; large amounts of oil and grease; 
urea, hydrogen sulfate; high temperature; and toxic organic chemicals. The measured and calculated values of the main pollutants are summarized in Table 1.1.1.

\subsubsection{Present Wastewater Treatment}

presently, each plant in the SIA has its own on-site treatment plant. The industrial wastewater treatment in the PIC consists of 1) a hydrolyzer to purify the high ammonia and urea, 2) neutralizing pits for neutralizing and mixing operations, and 3) oil skimmer units. The hydrolyzer treats the wastewater efficiently, except during a plant shutdown when the raw wastewater is diverted to the neutralizing pit, to the forest, or as overflow to the sea. The chemical and surface drain waters are diluted with the seawater used in cooling and then mixed with refinery industry wastewater. This mixture then goes directly to the Gulf. The main contaminants are $0 \mathrm{il}, \mathrm{NH}_{3}, \mathrm{COD}$ and urea.

At the KNPC refinery, the wastewater is collected in different drainage basins. The ammonia wastewater drain collects the wastewater contaminated with high ammonia and diverts it to the ammonical water treatment process. The sour water (with a high concentration of hydrogen sulfate) is collected and routed to the sour stripping unit, where the pre-treated water goes to the oil separator known as 
Table 1.1.1 Industrial hastenater Flous and Pollution Loads in the STA. (Source: Ref. No. 58).

\begin{tabular}{|c|c|c|c|c|c|c|c|c|c|c|c|c|c|}
\hline \multirow[t]{2}{*}{$\begin{array}{l}\text { Sea ortlet } \\
\text { point }\end{array}$} & \multirow[t]{2}{*}{ Industry } & \multicolumn{3}{|c|}{$\begin{array}{l}\text { Flow Pate } \\
\left(\mathrm{m}^{3} / \mathrm{h}\right)\end{array}$} & \multirow[b]{2}{*}{155} & \multicolumn{5}{|c|}{$\begin{array}{l}\text { Average pollution Laa* } \\
(\mathrm{kg} / \mathrm{d})\end{array}$} & \multirow[b]{2}{*}{$\alpha$} & \multirow[b]{2}{*}{ Tenp } & \multirow[b]{2}{*}{ PH } \\
\hline & & $\max$ & A & $\infty$ & & S Tho & Urea & $\mathrm{NH}_{4} \mathrm{~N}$ & M Oil & $\mathrm{H}_{2} \mathrm{~S}$ & & & \\
\hline D & MMI & 30 & 15 & 100 & 1500 & 1800 & 50 & 700 & 3 & 0 & 0.4 & 32 & 9.4 \\
\hline$B$ & $\begin{array}{l}\text { PIC } \\
\text { (South Sirface Drain) }\end{array}$ & 70 & 50 & 300 & - & $(80)$ & 10 & 70 & 4 & 0 & 0.6 & 29 & 8.8 \\
\hline$E$ & $\begin{array}{l}\text { PIC } \\
\text { (Ohentical Drain B) }\end{array}$ & 70 & 70 & 500 & - & $(400)$ & 90 & 300 & 30 & 0 & 0.2 & 60 & 8.8 \\
\hline ( & $\begin{array}{c}\text { PIC } \\
\text { (North Sirface } \\
\text { Drain B) }\end{array}$ & 70 & 20 & 700 & - & $(400)$ & 200 & 40 & 0 & 0 & 0.1 & $\mathbf{5}$ & 8.5 \\
\hline$E$ & $\begin{array}{l}\text { PIC A } \\
\text { Surface Orain }\end{array}$ & 90 & 25 & 800 & - & $(100)$ & 40 & 50 & 210 & 0 & tr & 40 & 6.5 \\
\hline$E$ & ANPC (API) & -1 & 150 & 1800 & (180) & $(300)$ & 0 & 280 & 480 & 60 & 1.6 & 55 & 10.0 \\
\hline$c$ & $\begin{array}{l}\mathrm{KOC} \\
\text { (LPF South) }\end{array}$ & $\infty$ & & & & & & & & & & & \\
\hline C & $\begin{array}{l}\text { KOC } \\
\text { (LPF South) } \\
\text { Oily thater }\end{array}$ & 60 & 50 & 1200 & - & - & 0 & 0 & 7 & 0 & tr & $\infty 0$ & 7.5 \\
\hline G & $\begin{array}{l}\text { KOC \& LPG North } \\
\text { (Ohemical Orain) }\end{array}$ & 10 & 5 & 50 & - & - & 0 & 0 & 3 & 0.1 & 0 & 33 & 7.6 \\
\hline$H$ & $\begin{array}{l}K O C+\text { LPG North } \\
\text { Zone } \\
\text { (Oilly itater Effluent) }\end{array}$ & 50 & 21 & 600 & - & (ख) & 0 & 20 & 30 & 2 & tr & 39 & 8.2 \\
\hline $\mathbf{F}$ & $\begin{array}{l}\text { PIC } \\
\text { (Keutral izing Pit } \\
\text { Effluent) }\end{array}$ & 80 & 50 & 400 & 03 & 37003 & 32004 & 400 & 35 & 0 & tr & 66 & 8.8 \\
\hline
\end{tabular}


the API. The surface drain effluent is also routed in the API. The overflow of this pit is diluted with cooling sea water and then routed to the Gulf. The main contaminants of this effluent are high $\mathrm{COD}, \mathrm{NH}_{3}, \mathrm{H}_{2} \mathrm{~S}, \mathrm{Oil}$ and organic compounds.

However, the effluent of the National Refinery at Mina Abdullah has no affect on the Arabian Gulf water quality, because this wastewater is routed into lagoons located in the desert. There is no data on the lagoon water quality.

Industrial wastewater from Kuwait $0 i 1$ Refinery is collected in settling tanks, the effluent is diluted with cooling seawater and then routed to the sea. Effluent from the chemical sump is treated similarly. The main pollutants here are oil, organics, COD and heavy metals. The Melamine industry's wastewater consists of cooling tower effluent and boiler blowdown discharge into the drainage system. The main pollutants are $\mathrm{NH}_{3}$, TKN and TSS.

With the present high concentrations of contaminants in the effluents and the high rate of wastewater produced and discharged into the Gulf, it appears without a doubt that the present treatment is not efficient nor is it sufficient to meet the recommended standards set by the SIA authority as shown in Table 1.1.2. Laboratory analyses have indicated that the wastewater carried high 
Table 1.1.2 Recomended Anbient Marine Enviroment Quality Oriteria for Inshore ters Around Shuaiba, (Source: Ref. No. 58).

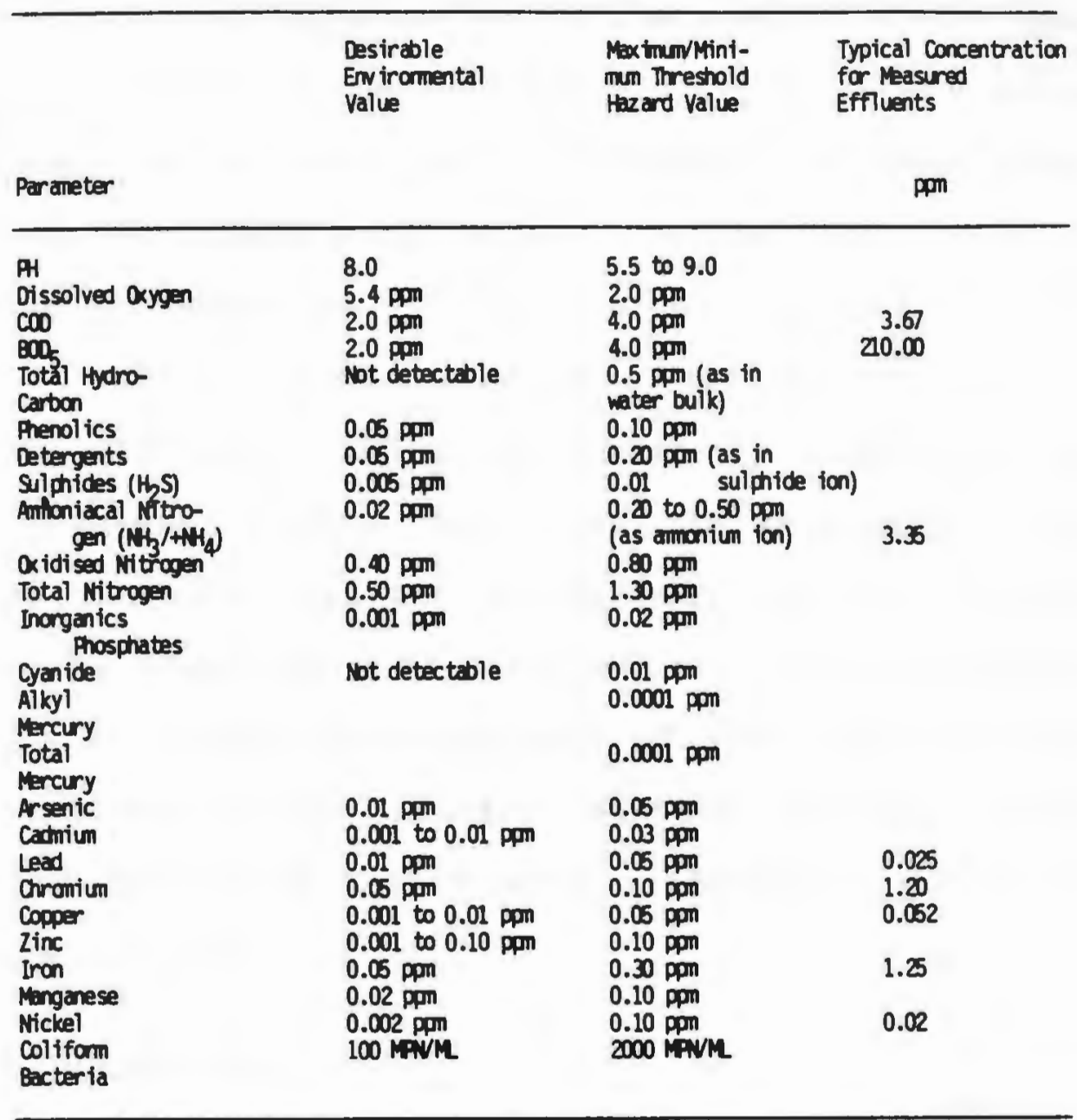

MPN = most probable nunber 
levels of ammonia, oil, $\mathrm{H}_{2} \mathrm{~S}$, urea, organic compounds, inorganic compounds and suspended solids. Presently these pollutants can have adverse effects on marine life. Some of these pollutants are carried into the desalination power plants due to the close proximity of the power plant intakes to the industry outlets. Treating high levels of pollutants with seawater dilution is not a solution to the problem. There are now plans to improve the present situation and lower pollutant loads by improving the primary treatment plants, but since the wastewater flows will also increase, the net improvement in water quality will not be significant. Therefore, this study was initiated to investigate methods of treating priority pollutants found in SIA refinery industry wastewater using a powdered activated carbon with activated sludge as a secondary treatment.

\section{2 objectives}

1. To investigate the application of activated sludge (AS) with powdered activated carbon (PAC) additions to treat a refinery industry wastewater by bio-removal of both conventional and priority pollutants.

2. To determine the biological kinetic constants in terms of $\mathrm{BOD}_{5}, \mathrm{COD}$ and $T O C$ for the activated sludge and for the activated sludge with addition of PAC at different carbon dosages. 


\section{LITERATURE REVIEW}

\subsection{Activated Sludge Treatment Processes}

Extensive studies on activated sludge (AS) treatment of refinery industry wastewater have demonstrated that organic pollutants could be removed by converting most organic pollutants to more stable inorganic forms such as $\mathrm{CO}_{2}$ and $\mathrm{H}_{2} \mathrm{O}$ or to cellular masses.

Stover et al. (64) investigated the fate and the treatability of specific organic compounds such as benzene, phenol, 1,2-dichloroethane, 1,2-dichloropropane and tetrachloroethane found in a complex industrial wastewater. An activated sludge reactor was used to treat a synthetic wastewater containing specific organic compounds individually or in various combinations. They found that the removal efficiencies were high for all compounds investigated. Compounds such as 1,2dichloroethane, 1,2-dichloropropane, and tetrachloroethane were stripped from the biological reactor.

However, Kincannon et a 1. (39) have shown that in addition to those compounds, benzene, methylchloride and 1,2-dichlorobenzene were completely stripped under identical conditions without a biological treatment. 
Travers et al. (69) investigated a completely mixed activated sludge reactor fed with an industrial wastewater containing a high concentration of fat and specifically to study its performance at different concentrations of dissolved oxygen (DO). They concluded that the fat present in the influent of wastewater will be degraded rapidly at higher DO concentrations (up to $4.0 \mathrm{mg} / \mathrm{L}$ ) and the sludge contained few filamentous microorganisms and low fat content and settled readily.

Shaul et al. (56) studied the removal of azo dyes from wastewaters using an activated sludge process. They showed that dyes in wastewater could be removed both by adsorption onto biological sludge solids and by biological degradation.

However, Reitano (54) reported that activated sludge removed about $40-80 \%$ of the $\operatorname{COD}$ where $C O D$ in the feed was in the range of 500 to $50 \mathrm{mg} / \mathrm{L}$ and that microorganisms could grow in concentrations of phenol of up to $200 \mathrm{mg} / \mathrm{L}$.

Gallagher et al. (26) discussed an activated sludge pilot plant for treating a pretreated gasification condensate containing high COD, phenols, and ammonia. The treated wastewater could be used as cooling tower makeup. They showed that an activated sludge pilot plant process with a higher sludge retention time (SRT) (20 to 30 days) was more stable and produced the highest quality effluent. In addition, there was a reduction in biodegradable 
organics in the range of $99 \%$ to $100 \%$. To obtain removal of thiocyanate, cyanide and ammonia in the wastewater required a long SRT (>20 days) combined with an increase in the hydraulic retention time to 3 days.

Lovett et al. (44) have shown that an industrial wastewater with high phosphorus could be effectively treated by an activated sludge process using sludge ages from 5 - 20 days. The effluent produced was low in phosphorus and total Kjeldahl nitrogen (TKN). They suggest further that feeding wastewater reactors continuously produced high effluent COD removal (>98\%).

\subsection{Addition of Powdered Activated Carbon To}

Improve Activated Sludge Treatment

For many years PAC was little used in chemical plants to remove suspended solids, organic compounds, color and odors because there was insufficient information about carbon design units and operating conditions. Also, there was no well-defined method to regenerate the carbon for reuse. Presently, new design methods and different ways of applying carbon have resulted in an increased use of carbon materials in wastewater and chemical plants $(6,50$, $71,75)$.

When activated carbon comes in contact with organic materials in wastewater, it removes compounds selectively by a combination of adsorption of less polar molecules, straining of the larger suspended particles and deposition 
of colloidal material on the exterior surface of the activated carbon. Removal of soluble organic compounds depends on diffusion of the dissolved particles onto the carbon surfaces. For colloidal particles, internal diffusion is important. Adsorption, in general, is a result of forces of attraction at the surface of a particle that cause soluble organic materials to be attracted and held on the surface. The activated carbon has a large surface area per unit weight, which makes it an efficient adsorptive material. In a wastewater plant, activated carbon is used as a tertiary process following a conventional secondary treatment unit. The efficiency of carbon adsorption in wastewater plants will depend first of all on the quality and quantity of the waste to be treated $(13,52)$.

Activated carbon can be classified into two groups: powdered and granular. Powdered activated carbon is produced by activating pieces of wood, charcoal, coconut shells and peats.

PAC has several advantages over granular carbon:

1. Lower capital costs. PAC requires less valves, piping, or columns.

2. Greater ability than GAC to control hydrogen sulfide gas.

3. Minimal pretreatment cost.

Activated carbon has been shown to remove chemical compounds present in waters and wastewaters which exhibit 
toxic, carcinogenic, mutagenic or teratogenic properties.

Previous studies have shown that addition of PAC to an activated sludge system not only improved the system's removal of organic pollutants, but increased the efficiency of the AS processes $(17,37)$. The studies have al so shown that in addition PAC will:

1. improve $B O D$ and $C O D$ removals despite high organic loading,

2. adsorb toxic materials present in the waste without biological treatment,

3. reduce color, foam and detergents from reactor and clarifier effluents,

4. improve solids settling in reactors as well as in clarifier effluents,

5. perform better over a wide range of organic and hydraulic loads,

6. improve plant operation efficiencies and save on capital investments because no additional equipment is needed, and,

7. reduce phosphorus concentrations.

During the aerobic oxidation, PAC adsorbs the organic pollutants dissolved in the waste stream. The adsorbed pollutants are degraded when they come in contact with biological organisms as follows:

Organic Pollutant + Bacteria $+\mathrm{O}_{2} \stackrel{\mathrm{N}, \mathrm{P}}{\longrightarrow} \mathrm{CO}_{2}+\mathrm{H}_{2} \mathrm{O}+$ cells.

It has been proven that some organic pollutants present in a receiving water are potentially dangerous to human and animal life. It is very important to gather 
information and data on the biodegradability and chemicalphysical treatability of these organic pollutants. Traditional treatment processes cannot meet the requirements for removal of all of the 129 organic compounds (see Appendix 1), but additions of PAC to the AS reactor were found to reduce influent levels of $B O D, C O D$, TOC and several priority organics such as benzene, ethylbenzene and toluene.

Weber. (79) reported that there is little information on the treatability of all of the priority pollutants present in the highly complex mixtures of organic compounds in refinery industry wastewater.

Adam (1) showed that additions of powdered carbon to a conventional activated sludge treatment system with an average $B O D$ of $1,700 \mathrm{mg} / \mathrm{L}$ and a COD of $3,200 \mathrm{mg} / \mathrm{L}$ increased COD removal by $25 \%$ and BOD removal by $20 \%$ during a two-month study. Another test that Adams conducted was at a municipal plant receiving about $70 \%$ of its industrial flow from a textile dyeing and finishing mill. A primary clarification tank effluent and a trickling filter effluent were directed to a contact stabilization basin. The BOD of the influent varied between 90 and $350 \mathrm{ug} / \mathrm{L}$. Powdered activated carbon was added at a dose of 20 to 25 $u g / L$ based on the influent flow rate. After five months of operation, BOD removals increased from about $70 \%$ to $90 \%$, and the solids settling improved. 
De John et al. (15) have evaluated PAC (Hydrodarco) added to AS systems to treat four refinery wastewaters. They reported for the first experiment that $B O D$ reduction was $82 \%$ and BOD removal reached about $90-95 \%$ when the carbon concentration reached $1,800-2,000 \mathrm{mg} / \mathrm{L}$ within the AS reactor. For their second experiment, they used a 12 MGO flow with TOC concentrations in the range of 100-1,000 $\mathrm{mg} / \mathrm{L}$. Carbon added at a dose of $100 \mathrm{mg} / \mathrm{L}$ produced a $20 \%$ reduction in the $T O C$ in the wastewater; however, when the carbon dosage was increased to $500 \mathrm{mg} / \mathrm{L}$ the effluent $B O D$ reached to $30 \mathrm{mg} / \mathrm{L}$. Their third experiment was conducted at a $2.5 M G D$ plant treating a $550 \mathrm{mg} / \mathrm{L}$ COD refinery wastewater in a two-stage conventional activated sludge system. Carbon was added at the rate of $200 \mathrm{mg} / \mathrm{L}$ over a six-week period. Effluent solids and COD removal increased to $40 \%$ and $B O D$ removal increased by as much as $90 \%$. Their fourth experiment was conducted at a 2 MGD plant treating refinery wastewater with a wide range of $\mathrm{pH}$ fluctuations. A PAC level of $400 \mathrm{mg} / \mathrm{L}$ was added and maintained daily. They reported that there was improvement in the BOD, COD, and SS removals, which reached the $90-95 \%$ range and the plant was able to meet the $30 \mathrm{mg} / \mathrm{L} B O D$ effluent standard.

Leipzig et al. (43) investigated treatment of the Salsbury (South Africa) Industry wastewater in five benchscale laboratory experiments, including (1) AS, (2) a 
carbon adsorption column, (3) PAC, (4) macroreticular resin adsorption and (5) solvent extraction. After a five-month study, they determined that when PAC was added to an activated sludge reactor with a HRT of 2 or 3 days, there was no difference in the performance. A daily carbon dosage of $167 \mathrm{mg} / \mathrm{L}$ added to a 2-day HRT reactor with a mixed liquor activated carbon concentration of 5000 $\mathrm{mg} / \mathrm{L}$ not only allowed nitrification to occur but provided an increase in TOC and color removal were $80 \%$ and $60 \%$, respectively.

Ferguson et al. (21) tested the addition of carbon to two activated sludge studies of batch and continuous-flow processes. A COD supplement was added to increase the COD concentration in the influent to about $200 \mathrm{mg} / \mathrm{L}$. Hydrodarco $H$ powdered activated carbon was used. From the batch study, they concluded that even when PAC in the reactor carbon was at a concentration of $90 \mathrm{mg} / \mathrm{L}$ there was poor removal of trichlorophenol. For their continuous study they found that a carbon dosage of 50 to $100 \mathrm{mg} / \mathrm{L}$ gave better performance than a unit that was receiving 95 $\mathrm{mg} / \mathrm{L}$ of trichlorophenol with PAC of $150 \mathrm{mg} / \mathrm{L}$. The sludge retention time had an effect on effluent quality. SRT values between 7 and 12 days were found to yield the highest effluent quality and increased trichlorophenol removal with a PAC dosage of $50 \mathrm{mg} / \mathrm{L}$; at a carbon dosage of $150 \mathrm{mg} / \mathrm{L}$, trichlorophenol was completely removed. 
Chao et al. (8) developed three completely mixed, continuous flow, activated sludge reactors. The wastewater feed consisted of $75 \%$ coke-plant wastewater and $25 \%$ sanitary wastewater. Five PAC doses $(200,300,500$, 700 and $1,000 \mathrm{mg} / \mathrm{L}$ ) were investigated with two HRT's. PAC added at a dose of $300 \mathrm{mg} / \mathrm{L}$ combined with shorter HRT's increased COD removals. They reported that addition of PAC at a dose of $300 \mathrm{mg} / \mathrm{L}$ not only improved cyanide removal but also reduced the sensitivity to fluctuations in the feed. They also pointed out that neither cyanide nor thiocyanate in the wastewater was adsorbable on the PAC.

DeWalle et al. (16) found that PAC dosages of 0,50 , 300 , and $1,000 \mathrm{mg} / \mathrm{L}$ to a $\mathrm{plug}-\mathrm{fl}$ low activated sludge unit and to units maintained at sludge ages of $3,5,10$ and 15 days would increase the percentage removal of organic matter. They reported that COD removal tended to be independent of sludge age.

Janeczek et al. (37) investigated the effect of PAC additions to six AS processes at doses of $250,500,1,000$, 2,500 and $5,000 \mathrm{mg} / \mathrm{L}$ for treating coal gasification wastewater diluted to one-quarter strength, at which BOD, COD and TOC were $2,000,4,425$ and $2,000 \mathrm{mg} / \mathrm{L}$, respectively and $\mathrm{pH}$ was between 7.8 and 7.9 . The major organic constituent was phenol. They reported that $97 \%$ of the COD was removed by $P A C$ and $52 \%$ of the COD was removed by a 
biological unit. Also $98 \%$ of phenol was removed by biological treatment but adding PAC increased its removal to about $99.99 \%$.

Heath (34) concluded that adding PAC to a 30 to 40 MGD DuPont plant with a complex chemical wastewater removed over $96 \%$ of the $B O D$ and over $80 \%$ of the DOC. Heath added that the plant achieved a solids concentration removal of about $40 \%$ in the clarifier. Organic removals increased at a carbon dose of $120 \mathrm{ppm}$ and higher sludge ages ( 20 to 60 days). Also $90-95 \%$ of the volatile organics and acid-extractable compounds were removed but base/neutral compounds were not removed. He also showed that PAC could be regenerated successfully in a multipleheath regeneration furnace.

Adams (2) studied the addition of powdered activated carbon to a 1 MGD municipal plant treating about $70 \%$ industrial wastewater from a textile dyeing and finishing mill. The influent $B O D$ ranged from $90 \mathrm{mg} / \mathrm{L}$ to $350 \mathrm{mg} / \mathrm{L}$, averaging $150 \mathrm{mg} / \mathrm{L}$. The effluent solids and color averaged $26 \mathrm{mg} / \mathrm{L}$ and 248 APHA units respectively before carbon was added. The HRT was about 2.2 hours. Adams found that $B O D$ removals were increased from 72 to $89 \%$ with an increase in the carbon dose from 20 to $25 \mathrm{mg} / \mathrm{L}$. Also, adding PAC at an average rate of $19 \mathrm{mg} / \mathrm{L}$ increased solids settling by $20 \%$. An equilibrium carbon dosage of $500 \mathrm{mg} / \mathrm{L}$ reduced the color from 670 to 320 APHA. Adams indicated 
that PAC could be regenerated using a wet air oxidation with reasonable losses of $6 \%$ to $30 \%$.

Flynn et al. (22) examined three bench-scale treatment units using industrial wastewater. Two units operated as PAC units and the third one was a biological unit. The PAC units were operated at different siudge ages ( 8.5 and 9.2 days). Flynn et a 1 . concluded that effluent quality improved with a sludge age of 9.2 days and/or increasing carbon dose to $150 \mathrm{mg} / \mathrm{L}$. In addition, a high sludge age ( 9.2 days) and low carbon dose $(124 \mathrm{mg} / \mathrm{L})$ produced an effluent similar to that from a unit operated at a lower sludge age ( 8.5 days) and a higher carbon dose $(150 \mathrm{mg} / \mathrm{L})$.

Flynn (23) tested a theoretical steady state model which incorporated the additions of PAC to an activated sludge process treating a wastewater containing heavy metals, dissolved dyes and organic compounds. Three separate tests were conducted with carbon dosages of 50 , 150 , and $650 \mathrm{mg} / \mathrm{L}$ at sludge ages of between 8.5 and 9 days. He concluded that BOD removal could be successfully modeled using a conventional kinetic approach.

Osantowski (51) et al. conducted PAC/AS studies to treat a raw pharmaceutical wastewater with a high $C O D$, for 83 days. The HRT's and SRT's were 3 days and 10 days, respectively. For the first test 208 and $827 \mathrm{mg} / \mathrm{L}$ of $P A C$ were added; in the second test, 496 and $1520 \mathrm{mg} / \mathrm{L}$ of PAC 
were used. The tests showed that PAC additions improved the removal of $\operatorname{COD}$ to about $90 \%$ but had no affect on the soluble CBOD (S-CBOD) of the effluent.

Heath (35) reported that PAC was added to a 40 MGD industrial wastewater treatment plant. The performance of the PAC exceeded expectations for BOD and color removal which were measured as $96 \%$ and $68 \%$ respectively. Removal of DOC and toxic and hazardous substances were also high. Also, operation at a sludge age of over 25 days reduced the required $P A C$ dose from more than $170 \mathrm{mg} / \mathrm{L}$ to $120 \mathrm{mg} / \mathrm{L}$. Heath found that the PAC could be regenerated with an $80 \%$ yield and a recovery of $63 \%$ of its virgin carbon properties.

Heath (36) discussed a 40 MGD plant which used the DuPont PACT process to treat an industrial wastewater from a variety of sources, to produce an effluent with the quality that could be achieved from secondary/tertiary treatment processes. The PACT process has been able to achieve a higher degree of treatment than could be obtained with a conventional actived sludge system. The influent had a soluble BOD of $280 \mathrm{mg} / \mathrm{L}$, a DOC of $205 \mathrm{mg} / \mathrm{L}$, a TDS of 2000-5000 mg/L and a TSS of $258 \mathrm{mg} / \mathrm{L}$. The PAC process used only $150 \mathrm{mg} / \mathrm{L}$ of carbon at a 8-day sludge age; it gave a BOD removal of over $95 \%$ and increased DOC removal from $62 \%$ to $85 \%$. Both color and foam concentrations were reduced and sludge settling was 
improved. Volatile organics such as benzene or chloroform and toluene and acid extractables such as 2-chlorophenol and phenol were removed, but base/neutral compounds $(1,2$ dichlorobenzene, and 2,6 dinitrotoluene) were removed with less success. Also, some heavy metals were removed. Mckay et al. (47) investigated the adsorptive capacity of PAC (Filtrasorb) for a number of pollutants (phenol, chlorophenol, dodecylhydrogen sulphate salt, mercuric ions, and chromic ions) in an aqueous solution. The Langmlir constants ( $\mathrm{mg} / \mathrm{g}$ ) have been determined and they were 213 for phenol, 434 for chlorophenol and 361 for dodecylhydrogen sulphate, 138 for mercuric ions, and 35 for chromic ions. Tests showed that the carbon capacities were particle size dependent and that differences in adsorptive capacities were linked to the solute-adsorbent bonding .

Garcia-Orozco et a 1 . (27) investigated eight reaction units operated for 4 weeks at sludge ages of between 4 and 12 days. Carbon was added at $70 \mathrm{mg} / \mathrm{L}$ to the first four reactors and no carbon was added to the other four. 4,6 dinitro-0-Cresol (DNOC), a priority pollutant was increased in concentration from 0 to $27 \mathrm{mg} / \mathrm{L}$ during the 4 weeks that the experiment was performed. TOC concentrations of the influent changed from 650 to 27 $\mathrm{mg} / \mathrm{L}$. A second carbon dose of $175 \mathrm{mg} / \mathrm{L}$ was added after 4 weeks. The test results showed that the assumptions on 
which the overall removal model was based were satisfactory (operational parameter, carbon dosage and sludge age) and they did represent the behavior of the PAC/AS process. The biodegradation rate coefficient, $K_{b}$, increased, but $Y$ decreased, based on TOC concentrations. carbon adsorption and biodegradation were the two mechanisms responsible for the DNOC removal.

Stensel et al. (62) studied the removal of organics from a refinery wastewater using an 800-gallon aeration tank in a pilot plant with a 1 iquid retention time of 14.3 hours. The feed to the aeration tank was 1 gallon per minute (gpm). They evaluated three processes for the removal of organics: filtration-activated carbon, biological treatment, and biological-filtration-activated carbon treatment. The design parameters for PAC were bed depth or contact time and organic loading. Stensel et al. showed that to maintain effluent quality at a COD of about $37 \mathrm{mg} / \mathrm{L}$ the operating time should be increased. Also, effluent from the biological treatment process had a higher organic loading due to poor adsorption of organics, but the activated carbon adsorption increased with increasing molecular weight and decreased with decreasing aqueous solubility and polarity.

Stenstrom et al. (63) investigated whether carbon additions would produce high effluent quality. Three experimental phases were conducted using five reactors. Four reactors were operated at a sludge age of 20 days and 
were fed with $100 \mathrm{mg}$ of carbon per 1 iter of wastewater feed. One reactor was left as a control. Tests showed that improvement in the effluent quality of the carbon-fed units over the non-carbon-fed unit ranged from $65 \%$ for soluble organics to $95 \%$ for phenolics. A carbon concentration of $200 \mathrm{mg} / \mathrm{L}$ yielded a high effluent quality. stenstrom et al. also concluded that less carbon added at a 60-day sludge age was the same as a high concentration of carbon added at a 30-day sludge age.

Flynn et al. (24) demonstrated that adding powdered activated carbon (65\% Nuchar SA and 35\% Hydrodarco C) to a 40 MGD aerator tank seeded with an industrial activated sludge yielded a $77 \%$ BOD removal. Increasing sludge age and temperature reduced the effluent's dissolved organic carbon (DOC) concentrations from 70 to $30 \mathrm{mg} / \mathrm{L}$ and reduced the effluent's $B O D$ from 30 to $8.4 \mathrm{mg} / \mathrm{L}$. Changing the carbon dose from 190 to $125 \mathrm{mg} / \mathrm{L}$ worsened the quality of the plant effluent slightly; DOC went from 28.6 to 40.3 $\mathrm{mg} / \mathrm{L}$ and $B O D$ went from 9.6 to $18.8 \mathrm{mg} / \mathrm{L}$. A low carbon dose $(80 \mathrm{mg} / \mathrm{L})$ with a long sludge age (29 days) produced an effluent quality equivalent to that of the PAC process ( $157 \mathrm{mg} / \mathrm{L}$ carbon and 7.3 days sludge age). Therefore, Flynn et al. concluded that a PAC process with a low carbon dose and a long sludge age would produce a highquality effluent.

Grabowski (27) described an agreement between a 
municipal wastewater facility and Sun's Marcus Hook Refinery Co. in Delcora, PA, in which Delcora would treat Hook Refinery wastewater as a joint treatment. Delcora had a secondary treatment plant, consisting of an activated sludge basin, a clarifier and a disinfection unit (chlorination). Grabowski indicated that, utilizing joint treatment, the Hook refinery would be able to control the organic pollutants in their final effluent.

Wallate et al. (74) discussed a $50 \mathrm{gpm}$ pilot plant using a solids-contact treatment, which operated for 24 hours per day to remove soluble organics from wastewater by adding PAC. They concluded that treatment with a PAC addition could remove more organic compounds than a single-stage treatment could. In a carbon system, a biological treatment was responsible for removal of more than $50 \%$ of the soluble organics. Also, in a system with less organics, the inorganic coagulant pretreatment could reduce the organic loading and in some cases eliminate the need for carbon additions.

Specchia et al. (60) reported that adding Norit SA-5 $P A C$ at a concentration of 0.2 to $0.1 \mathrm{gm} / \mathrm{L}$ to a $500-\mathrm{m} / 1$ Warburg-type respirometer fed with wastewater from a cotton and synthetic cloth dye-works helped to increase the removal efficiency for COD from 55.8 to $75.6 \%$ and increased BOD removals from 78 to $98.5 \%$ Also, the nitrification - denitrification capacity of the system was 
increased. Adding PAC reduced bacteria growth and increased the biological removal rates. Data collected from the experiment were used to calculate the biological oxidation constants.

Kincannon et al. (39) conducted two experimental studies on both non-biological and biological activated sludge systems. They used a 3-liter activated sludge reactor with a 3.23-1iter settling clarifier. The activated sludge system was operated at SRTs of 2,4 and 6 days and an HRT of 8 hours. 1,2 - dichloropropane, methylene chloride, benzene, ethylacetate, 1,2dichloroethane, phenol and 1,2-dichlorobenzene was added to a synthetic wastewater. It was shown that all compounds were stripped except phenol. Higher removal efficiencies were achieved based on BOD and TOC.

Frohlich et al. (25) assessed the use of biophysical treatment technology to treat effluents from both the pharmaceutical and fine organic chemicals industries. The $B O D$ and $T O C$ of the influent were about 7,470 and 14,970 $\mathrm{mg} / \mathrm{L}$ respectively. The system showed higher removals of COD, BOD, COlor, odor and nitrogen.

Zimpro (33) showed that addition of PAC in an activated sludge treatment would improve BOD removal from $58 \%$ to $97 \%$ and COD removal from $58 \%$ to $97 \%$, but the suspended solids removal increased from $73 \%$ to $91 \%$. Color was also reduced by between 150 to 500 APHA units. In the 
industrial sector, however, PAC reduced TOC and color by 93 and $98 \%$ while a biological treatment removed only 67 and $27 \%$, respectively.

\subsection{Priority Pollutants}

Specific organic compounds found in wastewaters are known as "priority pollutants". In the literature, investigators were concerned with defining better analytical methods for measuring and making assessments on the presence of these chemical compounds. Keith et al. (38) summarized the steps taken by U.S. EPA to develop a program for the priority pollutants in order to establish effluent limitations as well as guidelines. In the program, there were 129 priority pollutants. Each compound was analyzed to determine a monitoring level in the industrial discharges.

Chapman et al. (9) investigated the fate and the effects of the 129 priority pollutants in the environment based on their chemical behavior. They suggested that selection of individual priority pollutants for a monitoring program should be based on their anticipated fate and their effects in the environment.

Kincannon et al. (40) studied two mechanisms for removal of toxic priority pollutants. A 3-liter, activated sludge, completely mixed reactor was used with a 3.23-1iter settling compartment. The reactor was fed with 
a synthetic wastewater with a BOD between 250 and 300 $\mathrm{mg} / \mathrm{L}$. The activated sludge system was operated at 3 sludge ages (2, 4 and 6 days). The 2-1iter batch reactor had a mean residence time of 3 days. Kincannon found that nitrogen compounds, phenols and oxygenated compounds were removed by biodegradation. Aromatic compounds were removed by a combination of stripping and biodegration. Halogenated hydrocarbons were removed only by stripping. The study also indicated that a completely mixed reactor had better removal of priority pollutants than a batch reactor. Kincannon et al. also found that the larger the Henry's Law Constant the smaller the concentration of the priority pollutants in the final effluent.

Weber et al. (79) studied the effectiveness of three types of PAC added to a completely mixed flow bioreactor which contained the organic compound, Lindane. All three types of PAC removed about $96 \%$ of the Lindane at a carbon dosage of $30 \mathrm{mg} / \mathrm{L}$. However, increases in both sludge age (from 0.25 to 15 days) and retention time did not increase either COD removal or the Lindane concentration. Weber et a1. concluded that removal of priority pollutant compounds depends entirely on their chemical properties.

Tabak et al. (66) presented protocols to study biodegradation of organic priority pollutants. In his program a GC instrument was adapted as a tool to identify the organic priority compounds. Total and dissolved 
organic carbon analytical procedures were outlined.

Unger et al. (70) explained that percentage removals of priority pollutants and heavy metals vary significantly among wastewater plants. Metal and organic removals ranged from 32 to $81 \%$ and from 52 to $87 \%$, respectively. percentage removal of priority organics or heavy metals vary from plant to plant and even from sample to sample. The activated sludge process showed better removal for heavy metals such as $\mathrm{Cr}, \mathrm{Cu}, \mathrm{Hg}$, and $\mathrm{Zn}$. The study suggestech that removal treatments should be planned on a plant-by-plant basis.

Tabak et al. (65) studied the biodegradability of 114 organic priority compounds using a static-culture flask screening process. It contained $5 \mathrm{mg}$ of yeast extract per liter of a synthetic medium with a 5 and 10 $\mathrm{mg} / \mathrm{L}$ compound concentration. A 7-day static incubation period at $25^{\circ} \mathrm{C}$ was used. Three weekly subcultures were done with the addition of domestic wastewater as a microbial source. To test the biodegradability, DOC and TOC were determined for each compound. Results showed that priority pollutants did not degrade under staticculture conditions and therefore a new methodology should be developed.

Baller, et al. (5) explained the approach which had been taken by EPA to develop methods to measure hydrocarbon and chlorinated organic solvents in wastewater 
down to a concentration of $1 \mathrm{ug} / \mathrm{L}$. These methods are reliable in qualifying water-insoluble volatile organic compounds at a concentration as $10 \mathrm{w}$ as $0.5 \mathrm{ug} / \mathrm{L}$.

Thomas et a 1. (68) discussed EPA methods for analyzing priority pollutants in water by chromatography and chromatography/mass spectrometry (GC/MS). They also described sampling, storage, apparatus, sample preparation and gas chromatography analysis.

2.4 Air stripping

Air 'stripping methods have been used by petrochemical companies to treat wastewaters containing high concentrations of volatile compounds. Studies showed that for wastes containing volatile organic compounds, air stripping is a sufficient method of remoral. Engelbrecht et al. (17) studied stripping kinetics for acetone and butanone (methyl ethyl ketone) compounds using an 8.0-liter aeration tank at various air flow rates. Removals of acetone and butanone by air stripping could be described as first order kinetics. They concluded that the inorganics in wastewater required for the biological treatment processes would have no effect on stripability of the volatile compounds. The unit air flow rate $\mathrm{Ka}$, varies linearly with air flow.

Gaudy et al. (28) reported that first order stripping kinetics cannot be applied to all volatile compounds in a 11 experimental conditions. The variables that most 
affect the overall transfer coefficient, ka, are temperature, air flow, and tank geometry.

Gaudy et al. (29) investigated volatile organic compounds in a 28.3-liter activated sludge tank at various air flow rates starting with $100 \mathrm{ml} / \mathrm{min} / \mathrm{L}$ and increasing to $1200 \mathrm{ml} / \mathrm{min} / \mathrm{L}$. They concluded that joint mechanisms (air stripping and biological processes) were fairly good to predict kinetic constants. However, kinetic constants have no effect on the removal by either stripping or biological processes. Removals by either air stripping or biological methods were entirely dependent on the processes.

2.5 Industrial Wastewater Reclamation and Reuse

For years, many countries in the world have begun to reuse domestic and wastewater. The role of using reclaimed wastewater will increase in the future as drinkable water becomes scarce and expensive. Wastewater is a valuable source and could be used when treated and managed properly.

Laver et al. (42) explained that reused wastewater for potable water may become economically feasible with development of water treatment processes. In Denver, Colorado, a $1-M G D$ demonstration plant has been in operation for 3 years. The demonstration plant incorporated the following units: lime clarification, 
recarbonation, filtration, selective ion exchange, firststage carbon adsorption, reverse osmosis, air stripping, ozonation and chlorine dioxide disinfection. Ion exchange and carbon regeneration furnaces were also included. Treated wastewater was used directly to irrigate landscapes and part of the water was used by the city for nonpotable uses. The project will be run for 5 years to study its performance. Upon completion, the authority will be able to answer many questions related to future water reuse.

vuuren et al. (73) studied water reclaimed from a pond which had received a secondary effluent from a treatment plant. The pond water was treated by an algae separation unit and then by an active carbon adsorption unit. In 1976, an ammonia removal was implementated. They reported that the reclamation plant operated for a short period totaling 200 days and contributed about 1000 million liters of reclaimed water to the water supply network. Chemical and microbial analysis were done and strict monitoring was applied at all times.

DeBoer (14) explored the idea of using wastewater for reuse. Presently techniques are becoming available to convert wastewater to water safe for irrigation or to potable water. The public has still negative opinions on reused water. He stressed that the benefits of using a wastewater program are becoming known to the public. In 
Arizona, for example, without reused water programs, growth would be limited due to water shortages. In California, ground water aquifiers are already recharged with wastewater and no health effects have been observed on the public who used the reclaimed water.

Bruvold (7) conducted a public survey about using reclaimed wastewater as either drinking water or for nonpotable purposes. From the results of the survey he suggested that the best way to achieve public acceptance would be through the news media, lectures and advertising. Most of the public believed that the technology exists to treat wastewater sufficiently for potable reuse; however, they opposed the use of reclaimed water for drinking but for other purposes it would be acceptable.

Goff et al. (31) reviewed the construction of the 5 MGD wastewater reclamation facility for the city of Chandler, Arizona. A new water supply was needed; therefore, reuse of the municipal wastewater was being considered as a source to meet rapid growth in the community. Investigations were conducted to determine the most feasible way to use the reclaimed water. The plan was to reuse the reclaimed water for a golf course, a greenbelt area, as well as for residential and commercial development.

Crook (12) discussed water reuse in California within the past few years. California encouraged such uses as 
irrigation. Irrigation accounted for approximately $80 \%$ of the total quantity of wastewater reclaimed. Health criterias were established for various uses including irrigation, impoundments, and groundwater recharge.

Corssmit (11) reported on financing plans and price schedules for reused water. For the reuse project to be successful, four feasibility tests should be followed: (1) the technical aspects of the project should be understood; (2) the project must be economically desirable in term of costs and benefits; (3) the revenues must exceed the total cost; and (4) public opinion should accept the reuse project. Corssmit also pointed out that a market analysis should be done to make sure that there are demands for reused water. Mcclure (46) believed that the technology exists to develop and to produce high-quality reused water from either municipal sewage plants or from industrial wastes. Several industries tried successfully to reuse their cooling water for inside purposes. A steel mill and plating industry utilized significant amounts of potable water during their normal processes. $80 \%$ of this water could be reclaimed with an on-site treatment. Of course, depending on the characteristics of the wastewater, recommended steps would be added to make the water satisfactory for reuse.

Nellor et al. (49) evaluated the effects on human 
health from using groundwater recharged with municipal wastewater. Before being recharged into the groundwater, the wastewater was blended with stormwater and river water. Nellor et al. estimated that the wastewater-plant produced about 250,000 acre- ft of water each year, of which 67,500 acre-ft were reused and the remainder was discharged to the ocean. Replenished water did not show any measurable adverse effects on either groundwater quality or the health of the people ingesting the reclaimed water.

Shannon et al. (55) explained that odessa city, Texas relies completely on colorado municipal water for its main water supply. The watewater plant provides approximately $40 \mathrm{MGD}$, however, the amount will be increased in the future. There are two water reclamation plants, a conventional activated sludge plant, and an oxidation-ditch activated sludge plant. Both of these plants discharged their treatment wastewater into I andscapes where water either evaporates or percolates into the groundwater. A local industrial company uses secondary effluent for fire protection and cooling tower makeup, after the water is pre-treated by 1 ime clarification, filtration and zeolite softeners. Shannon et al. indicated that the future plan was to reuse the municipal wastewater for either landscaping, irrigation or recharging ground-water. 
Corneille (10) presented a master plan for wastewater reuse at Chino Hills Area, California. With the area expanding so fast, a water conservation program will be implemented to reduce the water supply requirement by $20 \%$ from normal usage. Therefore, the main objective was to maximize the use of reclaimed wastewater in order to make up for the $20 \%$ reduction in the water supply. The secondary treatment effluent disinfected with chlorine reclaimed water was used only for restricted landscape irrigation. For a densely populated area, he recommended that the quality of secondary effluent should be equivalent to a tertiary discharge. He claimed that reused water in lieu of potable water is currently economically attractive.

Culp et al. (13) explained that desalination plants provide coastal areas with the main supply of fresh drinking water. However, sea water contains about $3.5 \%$ dissolved salts plus a considerable amount of organic matter over 35 times as much foreign matter as secondary treatment plant effluents contain. For this reason and others, investments in desalination plants exceed the cost for a wastewater reclamation plant. They pointed out that the benefits from water reuse are not only to reuse the water but also to control pollution.

Most of the studies to date have concentrated on the removal of specific priority organics which were added to 
a synthetic waste. In addition many studies were constructed on a bench-scale and involved batch reactors. of the studies using pilot-scale reactors, none investigated the compounds that were studied in this dissertation. All of the AS operating parameters utilized in this study simulate those in a full-scale operation and the priority pollutants selected for this study (benzene, chloroform, 2,4-dimethylphenol, ethylbenzene, fluorene, naphthalene, pyrene, toluene, m-xylene, and o-xylene) are those found in an actual refinery waste. A study such as this fills a significant gap in the literature on refinery industry wastewater treatment. 


\section{EXPERIMENTAL PROCEDURE}

\subsection{Equipment}

The schematic of the PAC/AS pilot plant utilized in this study is shown in Figure 3.1.1. The pilot plant was manufactured by the Virtis Co. and it consists of 1) a 6 1 iter Pyrex glass reactor fitted with an air-tight stainless steel cover to prevent the escape of gasses, 2) a feed pump operated at $1.3 \mathrm{~L} / \mathrm{hr}, 3$ ) a $120-\mathrm{L}$ feed storage tank also with an air-tight cover, 4) a PAC slurry pump, 5) a clarifier pump, 6) a clarifier with a settling compartment volume of 2 liters and 7 ) an effluent receiving tank. A $120-L$ holding tank with a turbine impeller mixer rotating at $50 \mathrm{rpm}$ was used for the feed storage tank. To minimize the space in the holding tank, a floating $\mathrm{plate}$ was $\mathrm{placed}$ inside on the wastewater surface to keep the volatile organic compounds from escaping. The feed holding tank was air sealed (Figure 3.1.2). Two filters were connected to the effluent of the holding tank and they were in series. The first filter consisted of a chemical addition section and filtering fiberglass material. The second filter consisted of only a filtering fiberglass material. 


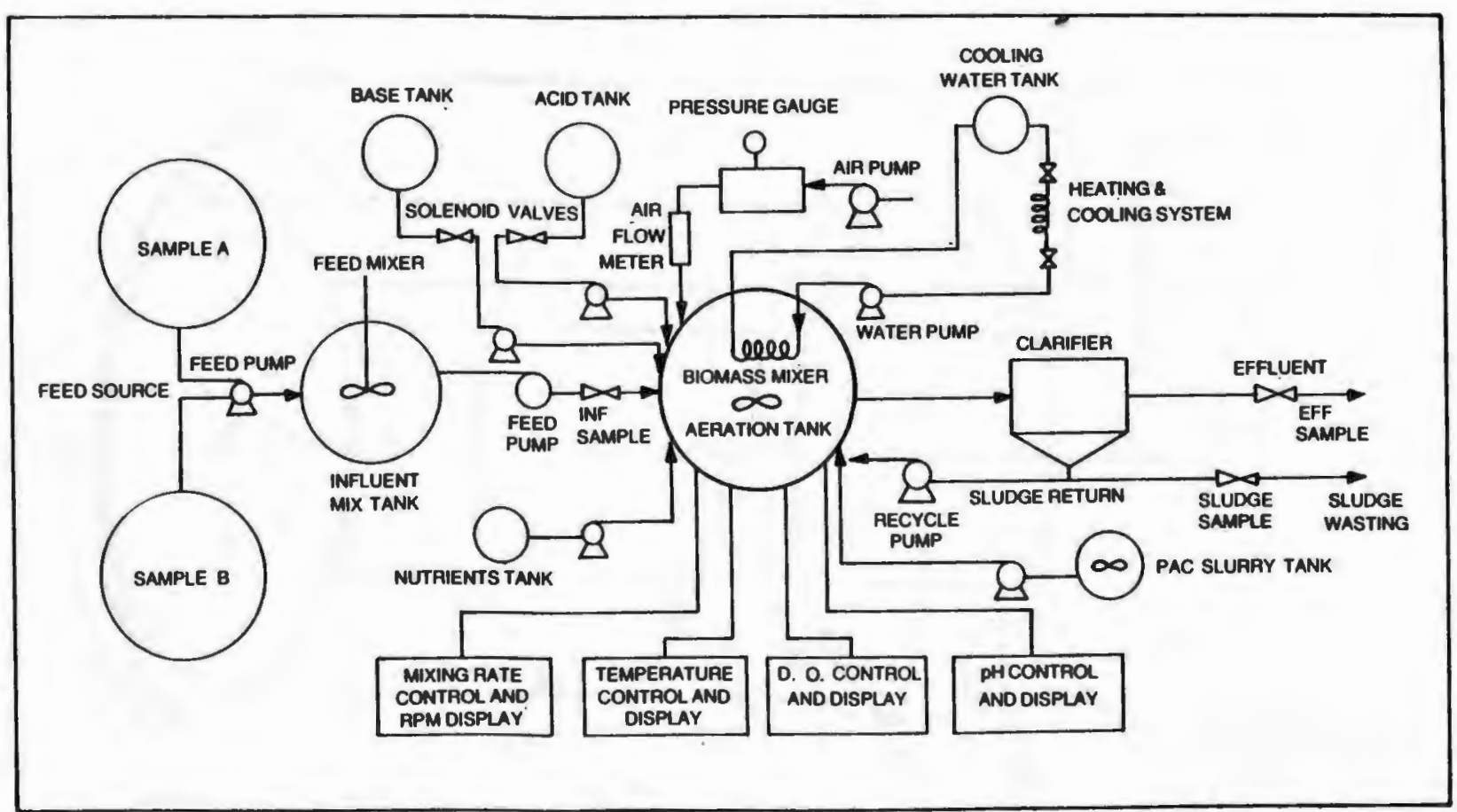

Figure 3.1.1 Schematic diagram of the Integrated PAC/AS Pilot Plant 


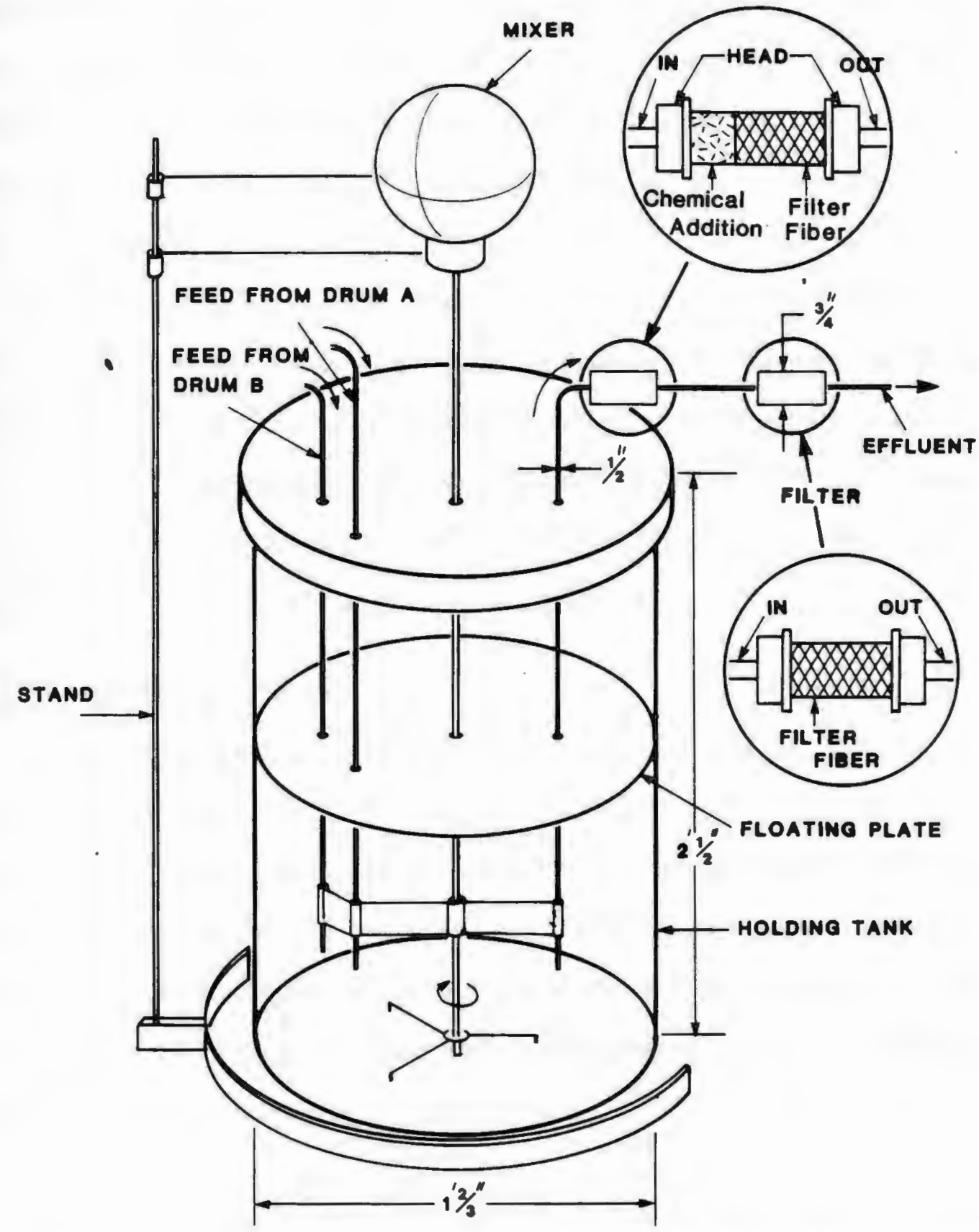

Figure 3.1 .2 Schematic of the Holding Tank and Filters 
The pilot plant was equipped with continuous monitoring and control devices for $\mathrm{pH}$, temperature, air pressure, dissolved oxygen, agitation system, cooling unit, and acid and base control. The pilot plant clarifier was fabricated from a one-liter funnel-shaped glass tank ( $10^{\circ} \mathrm{s} l o p e, 10 \mathrm{~cm}$ diameter, $\left.68 \mathrm{~cm} \mathrm{high}\right)$, as shown in Figures 3.1 .3 and 3.1 .4 .

PAC, manufactured by the Calgon Corporation, Pittsburgh, PA was used for this study. It has a maximum of $75 \%$ of the particles passing through a 325 -mesh screen. $A$ BL type PAC recommended by the carbon manufacturer was selected for this study. The specifications for PAC were provided by the manufacturer (Table 3.1.1).

\section{2 Experimental Steps}

The experimental phases were run at $3,6,9$ and 12 days sludge age $\left(\theta_{c}\right)$. These values are typical for conventional treatment processes. The characteristics of the refinery industry wastewater (physical and chemical parameters and organic loadings) were determined; they were identical to a discharged wastewater from a complex industrial area. 


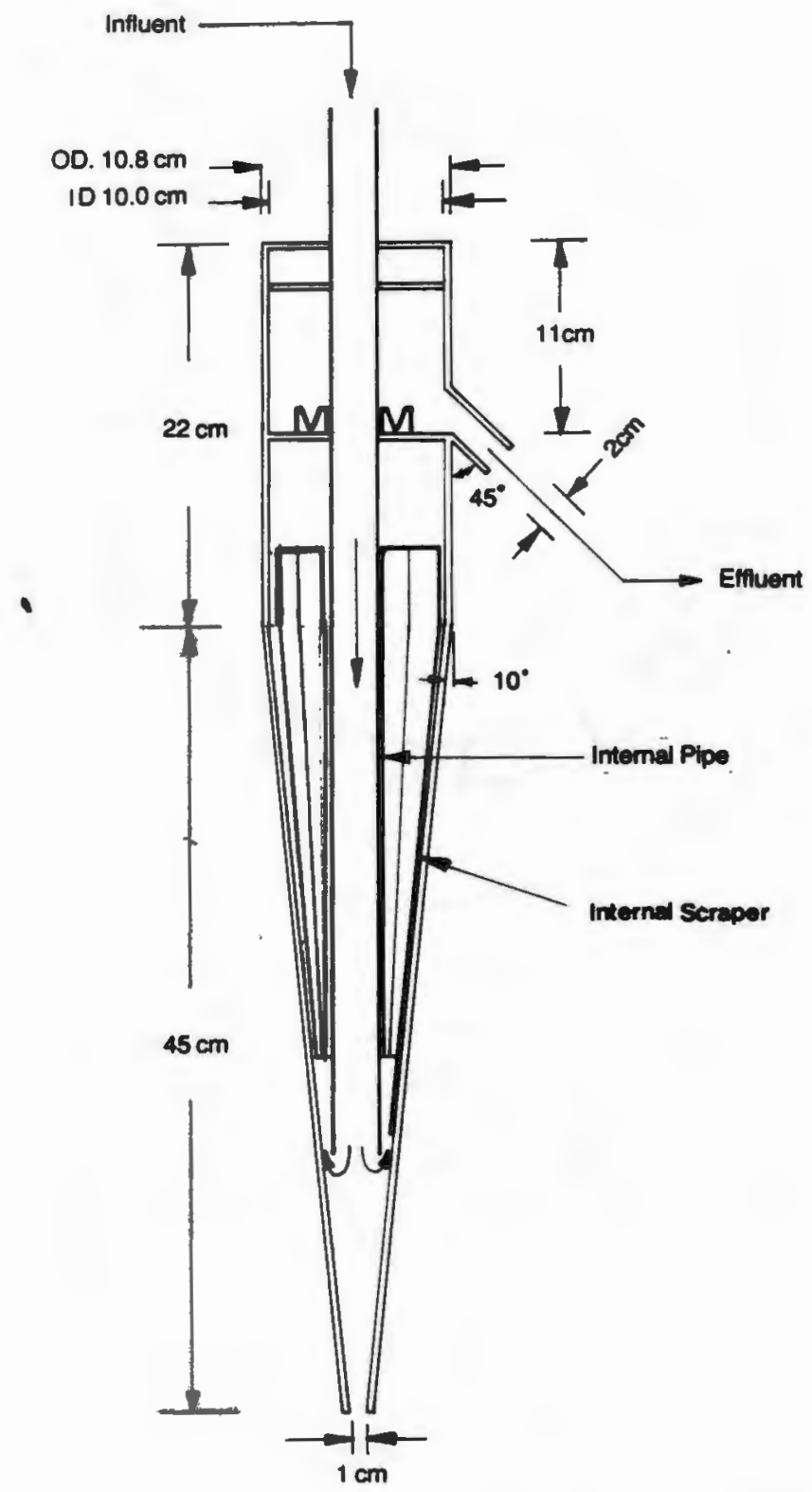

Figure 3.1.3 Schematic Diagram of the Experimental Clarifier Unit 

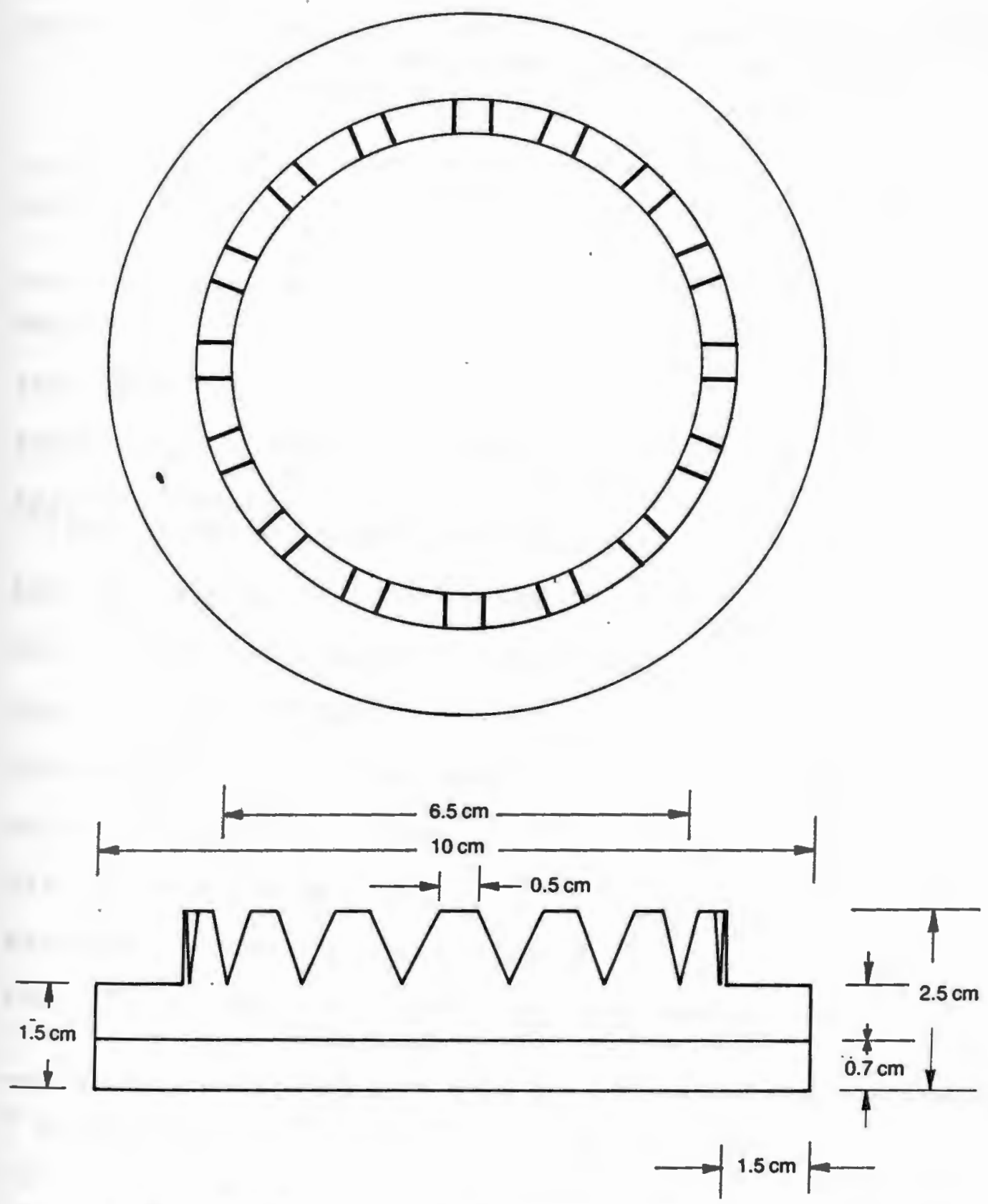

Figure 3.1.4 Schematic Diagram of the weir Inside the 
Table 3.1.1 Physical Properties of the BL Type of Powdered Activated Carbon (Calgon Corporation, Pittsburgh, PA)

Specifications

Carbon Type

BL

Manufacturer

Calgon

Base Material

Bituminous Coal

Total Surface Area (N2BET Method), $\mathrm{m}^{2} / \mathrm{g}$

$1000-1100$

Apparent'Density

(bulk density, dense packing), g/cc

0.51

Real Density He (displacement), g/cc

2.10

Pore volume (within particle), g/cc

0.90

Specific Heat at $100^{\circ} \mathrm{C}$

0.25

Iodine Number, minimum, $\mathrm{mg} / \mathrm{g}$

1000

Molasses Number, Minimum

230

Ash, maximum, wt $\%$

8.5

Mo isture, maximum as packed, wt \%

* Wet Screen Analysis, minus 325 U.S. Mesh \% 65.75

* U.S. Sieve Series; opening of 44 microns. 
The hydraulic retention time $(\theta=V / Q)$ in the aeration tank was designed to be around 4 hours. The clarifier effluent flow rate was approximately $20 \mathrm{ml} / \mathrm{min}(1.2 \mathrm{~L} / \mathrm{hr})$ and the recycling flow rate was about $0.10 \mathrm{~L} / \mathrm{hr}$. The design operating conditions of the biological pilot plant are listed in Table 3.2.1.

The temperature of the reactor was kept at $24^{\circ} \mathrm{C}$ for all experimental phases and the pH was between 6.80 to 7.20. The air flow rate was kept at $2.0 \mathrm{~L} / \mathrm{hr}$ which yielded, a concentration of dissolved oxygen in the aeration tank in the range of 5 to $6 \mathrm{mg} / \mathrm{L}$. The mixed liquor suspended solids (MLSS) concentration was in the range of 2,000 to $3,500 \mathrm{mg} / \mathrm{L}$, and the mixed 1 iquor volatile suspended solids (MLVSS) was about 1,500 to 3,000 $\mathrm{mg} / \mathrm{L}$. Solids were waste from the waste line in order to allow a more positive control of the sludge age than could be achieved by wasting from the reactor. During the test period 10,50 and $120 \mathrm{mg} / \mathrm{L}$ of PAC were added to the influent. To make up for PAC lost along with the waste sludge, clarifier effluent and aeration tank samples, fresh PAC was added to the influent feed line once per day. The characteristic of the refinery industry watewater feed to the biological pilot plant was given in Tables 3.2 .2 and 3.2 .3 . 
Table 3.2.1 Operating Conditions of the Biological Pilot Plant

Reactor

Volume

Hydraulic retention time, HRT

Air flow rate

$\mathrm{pH}$

Dissolved Oxygen (DO)

Flow rate

Agitation rate

Air pressure

Temperature

-PAC dosages

Holding Tank

vol ume

Mixing rate

Flow rate

$5.10 \mathrm{~L}$

$4.0 \mathrm{hr}$.

$1.5 \mathrm{~L} / \mathrm{hr}$

$6-8$

$5-6 \mathrm{mg} / \mathrm{L}$

$1.3 \mathrm{~L} / \mathrm{hr}$

$100-300 \mathrm{rpm}$

$3.0 \mathrm{psi}$

$24^{\circ} \mathrm{C}$

$10,50,120 \mathrm{mg} / \mathrm{L}$

Flow rate

$110 \mathrm{~L}$

$50 \mathrm{rpm}$

$1.3 \mathrm{~L} / \mathrm{hr}$

Clarifier

vol ume

Length

Shape

Top opening 0D, ID

Lower opening

$2.5 \mathrm{~L}$

$67 \mathrm{~cm}$

cone

$10.8,10.0 \mathrm{~cm}$

$1 \mathrm{~cm}$ 
Table 3.2.2 Characteristics of the Refinery Industry Wastewater

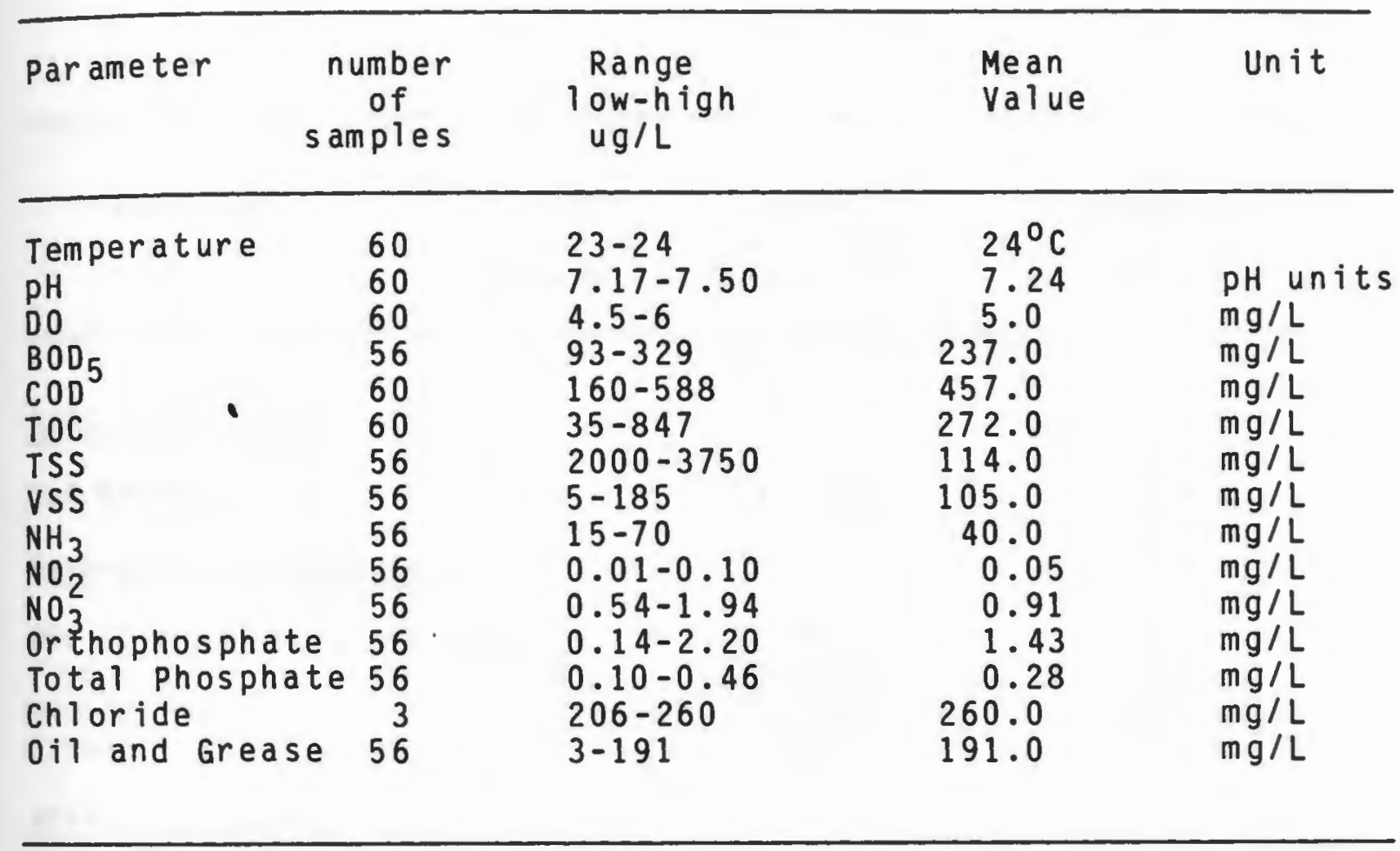


Table 3.2.3 Chemical Composition of the Refinery Industry Wastewater Treated by the Pilot Plant

\begin{tabular}{|c|c|c|c|}
\hline Parameter & $\begin{array}{c}\text { number } \\
\text { of } \\
\text { samples }\end{array}$ & $\begin{array}{l}\text { Range } \\
\text { low - high } \\
\text { ug/L }\end{array}$ & $\begin{array}{c}\text { Mean } \\
\text { Concentration } \\
u g / L\end{array}$ \\
\hline
\end{tabular}

Acid Extractables

2,4-Dime thyl phenol

6

$13-1,880$

452

Base-Neutral Extractables

Bis (2-ethylhexy1) phthalate 6

Fluorene

Naphthalene

Pyrene

Volatile Organics

Benzene

Chloroform

Ethylbenzene

Tolvene

$\mathrm{m}-\mathrm{xy}$ lene

o-xylene
$6 \quad 20-1,746$

$7 \quad 33-6,933$

5

27-33

767

354

1,358

32 


\subsection{Sampling Procedure}

Samples for analyses (Table 3.3.1) were collected every 24 hours for 5 days for phase $I$ and 3 days for phases II, III, and IV, for a continuous steady-state experiment. Composite samples were taken from the influent feed tank and the $c l a r i f i e r$ effluent. The sample containers were kept cool until the day of analysis. Composite samples of wasted mixed liquor were obtained from the wasting line before the daily volume of waste was measured and discarded. The contents of the holding tank, the aeration tank and the clarifier unit were mixed uniformly and completely before taking the sample. Parameters such as temperature, pH, air flow, and dissolved oxygen levels in the aeration tank were read directly from the pilot plant unit. Samples for mixed liquor and suspended solid were analyzed immediately after sampling. $\mathrm{BOO}_{5}, \mathrm{COD}$, TSS, and VSS were determined. Additional samples for analyses such as TOC, chloride, nutrients (nitrogen and phosphate), and oil and grease were done in the 1 aboratory.

Microorganism growth and population dynamics were examined by both light microscopes and scanning electron microscopes (SEM). After changes in the parameters of each run, a period of three to four days was needed for 
Table 3.3.1 Sampling and Analytical Work Schedule for the Biological Treatment Pilot Plant

\section{Sampling Location}

Parameter

Influent

Reactor

Effluent Frequency

Temperature

$\mathrm{pH}$

Air Flow

Flow Rate

DO

$\mathrm{BOD}_{5}$

COD

TOC

Suspended Solid

Vol atile (MLVSS/VSS)

Fixed (TSS)

Nitrogen

$\mathrm{NH}_{3}$

$\mathrm{NO}_{2}$

$\mathrm{NO}_{3}$

$0 i 1 /$ Grease

Total Phosphate

Or thophosphate

Organics

Volatile

Acid/Base Extractable $x$

$x$

$x$

$x$

$x$

$x$

$x$

$x$

$x$

$x$

$x$

$x$

$x$

$x$

$x$

$x$

$x$

Daily

$x$
Daily

Daily

Daily

Daily

Daily

3 times/week

3 times/week

3 times/week

3 times/week

3 times/week

3 times/week

3 times/week

3 times/week

3 times/week

3 times/week

3 times/week 
the biomass to reach steady-state conditions.

\subsection{Analytical Methods}

Selected priority organic compounds were analyzed according to the instructions given in the Federal Register $(37,81,82)$. All other analyses were performed according to the standard Methods for the Examination of Water and Wastewater (61).

TOC Was measured using a TOC Model 700 analyzer made by 0.I. Corporation. Ammonia was determined by the acidimetric method. Nitrite $\left(\mathrm{NO}_{2}\right)$ was measured using the diazotization method. Nitrate $\left(\mathrm{NO}_{3}\right)$ concentrations were determined by the bucine method. The stannous chloride method was used for both total phosphate and soluble orthophosphate. Chloride was measured by the argenometric method. $0 i 1$ and grease method in the Standard Methods was modified as follows: A $150-\mathrm{ml}$ sample was collected and actified to $\mathrm{pH} 2$ or lower using $5 \mathrm{ml}$ of concentrated $\mathrm{HCl}$. The acidified sample was transferred to a separatory funnel and the sample container was washed with $10 \mathrm{ml}$ of trichloro-trifluoro-ethane as a solvent, the wash liquid was then also transferred to the separatory funnel. Then the separatory funnel was shaken vigorously for 2 minutes and allowed to stand for 10 minutes or longer, so that the organic layers separated after excess gas venting. 
The separatory layer was drained off through a funnel containing clean filter paper and the solution was collected in a distillation flask. Then the sample was extracted twice with $10 \mathrm{ml}$ of solvent and the extractable materials were transferred to the distillation flask. The filter paper was washed with 10 to $20 \mathrm{ml}$ of solvent and the washable liquid was transferred into the distillation flask. The distillation flask was placed in a water bath at $70^{\circ} \mathrm{C}$ for 15 minutes. The flask was then put in a desicator to cool for 30 minutes and was weighed.

The procedure for extracting the samples (base/neutral and acid extractables) and determining the selected priority organic pollutants are discussed in the following sections.

\subsubsection{Sample Preparation}

EPA base/neutrals and acid method 625 (72) describes the determination of organic compounds that are soluble and able to be measured by gas chromatography. Methylene chloride was used as a solvent to extract the dissolved organic compounds at a selected pH. The extract was dried and concentrated to a volume of $1 \mathrm{ml}$ and analyzed by GC. The chromotographic conditions were modified for measuring the organic compounds at their concentrations in the refinery industry wastewater. (Tables 3.4.1.1, 3.4.1.2, $3.4 .1 .3,3.4 .1 .4)$. 
Table 3.4.1.1 Tekmar Model LSC-2 Conditions for Analysis of Purgeable Organ ic Compounds

Furnace

Trap material

Sample size

Times

Temperature readouts

Purge pressure

Purge flow rate

Bake temperature
Range ambient to $350^{\circ}$. Rise time $200^{\circ} \mathrm{C} / \mathrm{min}$ Tenax (Silica Gel/charcoal, 12" x 1/8")

$5 \mathrm{ml}$, medium porosity glass frits including 3-way manual valve for sample load, unload, front drain.

Purge $15 \mathrm{~min}$, Dry purge on timer set on 11 . Desorb $4.0 \mathrm{~min}$.

Bake $7 \mathrm{~min}$

Auto positions

20 psi

$40 \mathrm{ml} / \mathrm{min}$

$180^{\circ} \mathrm{C}$ 
Table 3.4.1.2 Gas Chromatographic Conditions for Photoionization Detection (PID)

Initial temperature

$45^{\circ} \mathrm{C}$

Final temperature

$200{ }^{\circ} \mathrm{C}$

Programming rate

$8^{\circ} \mathrm{C} / \mathrm{min}$

Initial hold

$3 \mathrm{~min}$

Final hold

$15 \mathrm{~min}$

Detector temperature

$250^{\circ} \mathrm{C}$

Injection temperature

$200^{\circ} \mathrm{C}$

Carrier gas, He

$40 \mathrm{ml} / \mathrm{min}$

Col umn

60/80 Carbopack B

$1 \%$ SP 1000

Glass 
Table 3.4.1.3 Gas Chromatographic Conditions for Hall Electrolytic Detection (HALL)

Initial temperature

Final temperature

Program rate

Initial hold

Detector temperature

Injection temperature

Final hold

Carrier gas, He

Reactor gas, $\mathrm{H}_{2}$

Column $45^{\circ} \mathrm{C}$

$200^{\circ} \mathrm{C}$

$8^{\circ} \mathrm{C} / \mathrm{min}$

$3 \mathrm{~min}$

$200^{\circ} \mathrm{C}$

$200^{\circ} \mathrm{C}$

$15 \mathrm{~min}$

$40 \mathrm{ml} / \mathrm{min}$

$50 \mathrm{ml} / \mathrm{min}$

$60 / 80$ Carbopack B

$1 \%$ SP 1000, Giass 
Table 3.4.1.4 Gas Chromatographic Conditions for Flame Ionization Detection (FID)

Initial temperature

$50^{\circ} \mathrm{C}$

Final temperature

$200^{\circ} \mathrm{C}$

program rate

$10^{\circ} \mathrm{C}$

Initial hold

$2 \mathrm{~min}$

Detector t'emperature

$240^{\circ} \mathrm{C}$

Injection temperature

$220^{\circ} \mathrm{C}$

Carrier gas, He

$50 \mathrm{ml} / \mathrm{min}$

Reaction gas, Air

$0.2 \mathrm{l} / \mathrm{min}$

Reactor gas, $\mathrm{H}_{2}$

$50 \mathrm{ml} / \mathrm{min}$

Mode

Splitless

Column

$20 \mathrm{~m} \times 0.23 \mathrm{~mm}$ ID

SE-54 fused silica

capillary, custom made 
The extraction procedure was as follows: The base/neutrals and acid extractable samples were collected from the influent and effluent at sample points in the biological pilot plant. Each $150 \mathrm{ml}$ sample was collected and poured into a 250-m1 separatory funnel. The pH of the sample was adjusted to above $\mathrm{pH} 11$ by adding $1 \mathrm{ml}$ of $10 \mathrm{~N}$ sodium hydroxide $(\mathrm{NaOH})$. The sample was extracted three times with $10 \mathrm{ml}$ of methylene chloride each time. The extracted sample in the separatory funnel was shaken for two minutes each time with periodic venting to release excess pressure produced by gases in the funnel. At least 10 minutes was allowed each time for the organic layer to separate from the water phase. The combined methylene chloride extracts contained the base/neutral extractables. The combined extract was poured through a drying column containing about $10 \mathrm{~cm}$ of anhydrous sodium sulfate, and then the extract was collected in the K-D concentrator. One or two clean boiling stones were added into the $\mathrm{K}-\mathrm{D}$ concentrator and then the extract was placed into the prewetted Snyder Column. The K-D apparatus was placed in a hot water bath at $65-70^{\circ} \mathrm{C}$ and the concentrator tube was immersed in the hot water. The $K-D$ apparatus was removed from the water bath when the apparent volume of the extract reached $1 \mathrm{ml}$. The apparatus was left to drain for at least 10 minutes. The Snyder column was removed from 
the lower part. The lower flask with the concentrator tub was rinsed with 1 to $2 \mathrm{ml}$ of methylene chloride. The concentrated liquid was collected in a $1 \mathrm{ml}$ vial and was ready to be injected to the $G C$ instrument. The $P H$ of the aqueous layer left from the base/neutral extraction was readjusted to less than 2 by addition of approximately 1 ml of sulfuric acid $(1+1)$. The aqueous phase was extracted three times with $10 \mathrm{ml}$ of methlylene chloride each time. The combined extracts contained the acid extractabjes and were then treated in exactiy the same way as the base/neutral extractables.

To estimate the amount of powdered activated carbon PAC present in the MLVSS the following procedure was utilized by the Zimpro Inc. Laboratory, Wisconsin The procedure is applicable only to the wastewater carbon/biomass from an integrated powdered PAC and $A S$ process. The procedure is known as nitric acid digestion and it yields an estimate of PAC in a carbon/biomass slurry. The determination of biomass and carbon was done by comparing the VSS of a nitric acid digested sample with the normal VSS and finding the ratio between activated carbon and biomass solid. The procedure for biomass determination in a nitric acid digestion sample was as follows: 
1. Run normal suspended solids tests using a $10 \mathrm{ml}$ sample, dry it at $600^{\circ} \mathrm{C}$ for one hour, then measure the suspended ash.

2. To another $10 \mathrm{ml}$ aliqout of the sample, add $20 \mathrm{ml}$ of concentrated nitric acid.

3. Heat the acidified sample to just under boiling.

4. Continue heating until the sample volume has been reduced to approximate 1 y $10 \mathrm{~m} 1$.

5. Cool the sample to room temperature.

6. Determine the suspended solids and ash on the digested sample.

7. Calculate the results.

8. The carbon and biomass concentrations could be determined as follows:

$$
\begin{aligned}
& \text { Carbon, } g / L=\frac{C-D}{0.95} \\
& \text { Biomass, } g / L=A-(B+\text { Carbon })
\end{aligned}
$$

where
$A=$ Normal suspended solids, $g / L$
$B=$ Normal suspended ash, $g / L$
$C=$ Nitric acid treated suspended solids, $g / L$
$D=$ Nitric acid treated suspended ash, $g / L$
0.95 = Carbon factor 


\subsection{Seeding Refinery Industrial Wastewater}

Initially, refinery industry wastewater was seeded with seed organisms obtained from the South kingstown Wastewater Treatment plant in Narragansett, Rhode Island. Five ml of clarifier activated sludge was obtained and acclimated to the refinery industry wastewater. The suspended solid concentration in the clarifier was in the range of 2:000-3,000 mg/L. Ammonia, sulfate [(NH4) $\left.2 \mathrm{SO}_{4}\right]$ and potassium phosphate $\left[\mathrm{K}_{2} \mathrm{H}^{\mathrm{P} 0_{4}}\right]$ were added as $\mathrm{N}$ and $\mathrm{P}$ nutrient sources. The refinery industry wastewater was fed directly into the seeded activated sludge aeration tank continuously. Parameters such as pH, temperature, dissolved oxygen and nutrient concentrations were kept constant. The biological pilot plant required between 4 and 5 weeks to reach a MLSS concentration of $2,200 \mathrm{mg} / \mathrm{L}$.

\subsection{Start-up of the Biological Pilot Plant}

The biological pilot plant was operated continuously after being seeded, and achieved the steady-state conditions based on the MLVSS and MLSS. measurements. To keep the concentration of priority organic compounds in the holding tank high enough to be detected by a GC instrument, organic materials had to be added and dissolved uniformly in the feed tank. Two filters were connected to the effluent of the feed tank in order to 
trap any suspended particles and organic materials from getting into the aeration reactor tank. The hydraulic retention time (HRT), and sludge age (SA) or sludge retention time (SRT) of the biological pilot plant were controlled at 4 hours and $3,6,9,12$, days respectively. Daily wasting of mixed liquor was performed once per day through the wasting sludge point to control the sludge age. PAC was added directly to the aeration tank. The concentration of PAC was calculated based on the required PAC concentration in the mixed liquor. 
4. CHARACTERIZATION OF THE STANDARD REFINERY WASTEWATER

4.1 Data Collection

During the summer of 1985 , a study was conducted in the Shuaiba Industrial Area (SIA) to determine the chemical composition, flow rates, and discharge points for industries in the SIA (67). The Kuwait National Petroleum Company Refinery (KNPC) and the Petrochemical Industrial Companies (PIC) plants $A$ and $B$ are considered the major sources of wastewater discharged directly into the Arabian Gulf. Composite samples were collected from the Shuaiba Industrial Area at the discharge points at a location prior to mixing with seawater. These samples were analyzed for $\mathrm{BOD}_{5}, \mathrm{COD}$, nitrates, nitrites, ammonia, $\mathrm{PH}$, phenol, oil and grease, and selected heavy metals such as chromium $\left(\mathrm{Cr}^{+6}\right)$, copper $(\mathrm{Cu})$, iron $(\mathrm{Fe}), \mathrm{lead}(\mathrm{Pb})$, and nickel (Ni). The analyses were conducted according to Standard Methods (61). The results of these analysis are presented in Table 4.1.1.

The hydraulic flow survey showed that the mean daily flow to the KNPC API separator was about $960 \mathrm{gpm}$, but the flow to the PIC neutralizing basin was approximately 63 gpm. There was no change in the pattern of the wastewater flow at night or during the weekends in both the operation of the KNPC Refinery and PIC Fertilizer Company, Plant B. Chemical analyses of grab composite samples were made 
Table 4.1.1 Results of Analysis for the Composite Samples From the KNPC-API Separator and PIC Plant B.

\begin{tabular}{|c|c|c|c|c|}
\hline Parameter & $\begin{array}{c}\text { Sample } \\
1 \\
(6 / 4 / 85)\end{array}$ & $\begin{array}{l}\text { Number (D } \\
2 \\
(6 / 17 / 85)\end{array}$ & $\begin{array}{l}\text { ate) } \\
3 \\
(6 / 30 / 85)\end{array}$ & $\begin{array}{l}\text { Average } \\
\text { Concentration } \\
(\mathrm{mg} / \mathrm{L})\end{array}$ \\
\hline $\mathrm{NH}_{3}-\mathrm{N}$ & 3.35 & 3.13 & 2.85 & 3.11 \\
\hline $\mathrm{NO}_{3}-\mathrm{H}$ & 0.38 & 0.026 & 0.003 & 0.14 \\
\hline $\mathrm{NO}_{2}-\mathrm{N}$ & 0.13 & 0.026 & 0.010 & 0.055 \\
\hline Phenol & 0.62 & 3.25 & 4.91 & 2.97 \\
\hline $\mathrm{COD}$ & 375.7 & 592.2 & 132.2 & 367.0 \\
\hline $\mathrm{BOD}_{5}$ & 320 & 100 & - & 210 \\
\hline $0 i 1$ and Grease & 2.60 & 150 & 95 & 82 \\
\hline Sulphides & 3.42 & 0.078 & 3.89 & 2.46 \\
\hline $\mathrm{Fe}$ & 1.39 & 0.88 & 1.50 & 1.25 \\
\hline $\mathrm{Cr}^{+6}$ & 0.084 & 1.88 & 1.63 & 1.20 \\
\hline $\mathrm{Pb}$ & 0.019 & 0.032 & 0.024 & 0.025 \\
\hline $\mathrm{Cu}$ & 0.084 & 0.041 & 0.031 & 0.052 \\
\hline $\mathrm{Ni}$ & - & 0.022 & 0.017 & 0.020 \\
\hline
\end{tabular}


every other week over a one-month period. The results of these analyses are presented in Table 4.1.1, on page 65.

The composite samples were also analyzed for their organic priority pollutant composition. The analyses were conducted according to the USA Environmental protection Agency Method No. 601 for purgeable halocarbons, Method No. 602 for purgeable aromatics $(19,20)$ and Method No. 625, for dissolved organic compounds. A GC was used to measure the concentrations of dissolved organic pollutants: The results are presented in Tables 4.1 .2 and $4 \cdot 1.3$.

\subsection{Selection of Priority Pollutants}

According to the regulatory agency (kuwait Environmental Protection Council), there are several factors which should be considered to determine the selection of priority pollutants. These factors are as follows: (1) toxicity in the water, (2) presence in the water, (3) highest concentration in the water, (4) frequency of occurance, and (5) effects on human and aquatic life.

Samples were collected from SIA and analyzed for pollutants. For the determination of the organic pollutants, GC-MS was used to identify the priority pollutants. The analyses showed that the following compounds were present: 
Table 4.1.2 Extractable Organic Compounds Found in KNPC API Effluent

\begin{tabular}{lll}
\hline Compound & $\begin{array}{l}\text { Average } \\
\text { Concentration } \\
\text { ug/L }\end{array}$ & $\begin{array}{l}\text { Extractable } \\
\text { Fraction }\end{array}$ \\
\hline $\begin{array}{l}\text { Naphthalene } \\
\text { 2,4-Dimenthyl Phenol }\end{array}$ & 121.0 & Base/Neutral \\
$\begin{array}{l}\text { Phenol } \\
\text { Fluorene }\end{array}$ & 50.4 & Acid/Neutral \\
Pyrene & 25.2 & Acid/Neutral \\
Chrysene & 16.0 & Base/Neutral \\
Bis (2 Ethyl Hexyl) & 10.0 & Base/Neutral \\
Phthalate & 6.0 & Base/Neutral \\
\hline
\end{tabular}


Table 4.1.3 Halocarbon and Aromatic Compound Concentrations Found in Wastewater of KNPC API Separator Effluent.

Compound

Concentration

( ug/L)

Chloroform

740

Benzene

560

Toluene

660

Ethylbenzene

120

Xylene

500 
benzene, bis $(2$-ethylhexyl) phthalate, chloroform, chrysene, 2,4-dimethylphenol, ethylbenzene, fluorene,

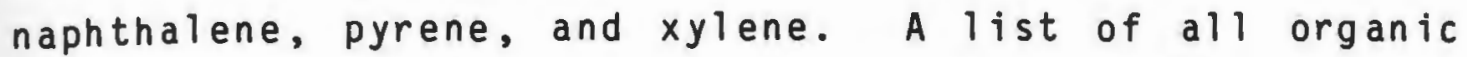
priority pollutants found in SIA is given in Tables 4.1 .2 and 4.1 .3 .

The selection of organic priority compounds for this study was not only based on the relative toxicity, but on their presence in the SIA discharge wastewater. Taking into account the utilization of seawater for drinking water after desalination, the following priority pollutants were selected for this study: benzene, chloroform, 2,4-dimethylphenol, ethylbenzene, fluorene, naphthalene, pyrene, toluene, and xylene. Table 4.2.1 shows the different chemical and physical characteristics of the selected compounds. Several wastewater characteristics were also identified including $B O D_{5}, C O D$, TOC, TSS, nitrogen, and $\mathrm{pH}$. 
Table 4.2.1 Chemical and Physlcal Characterlatics of Solectod Prlority Organle Pallutants

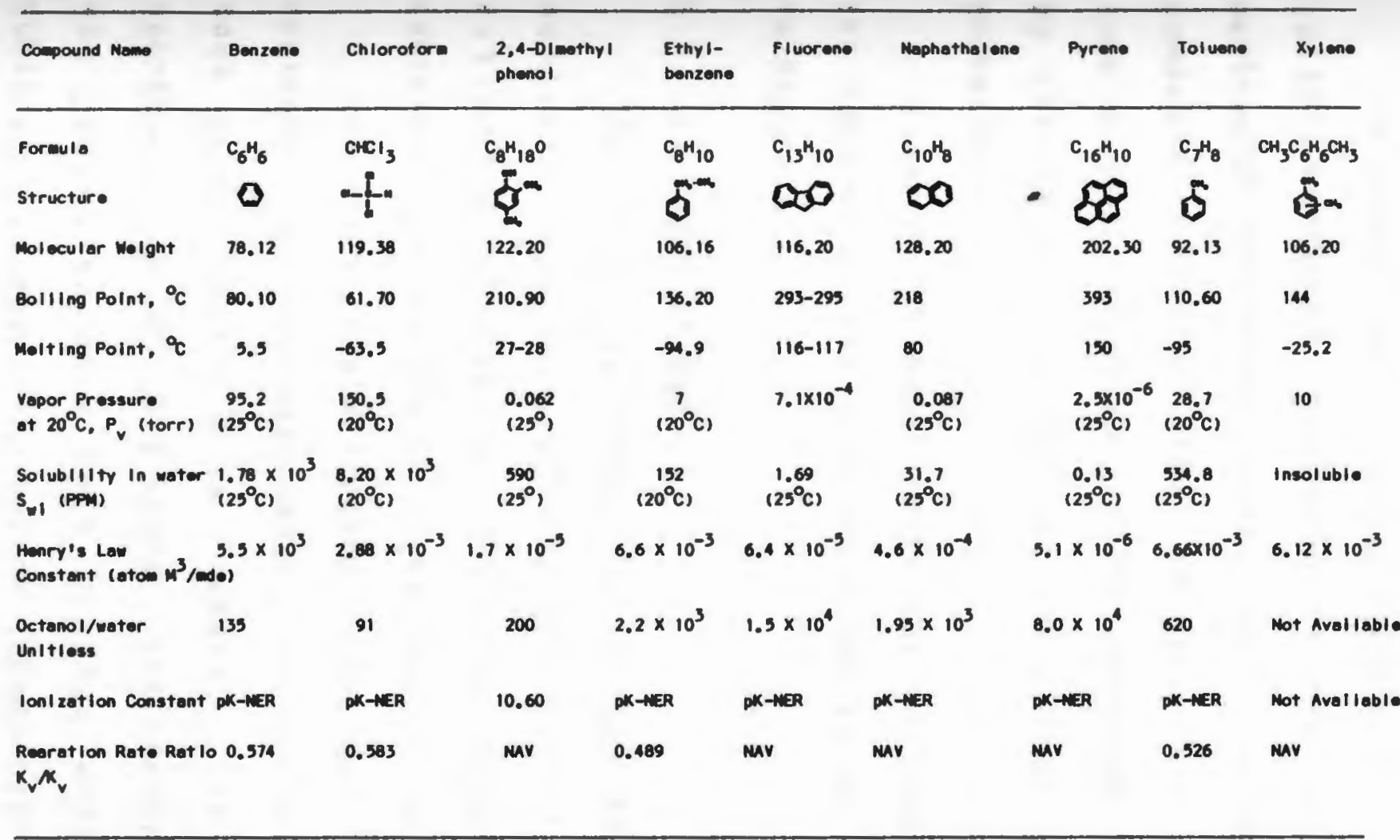

Note: MAV = not applleable for colculating the rote constant for volatizotlon pK-HER = pke or pKr Is not environmentally relevent for fote of chemicals 


\section{PRIORITY ORGANICS REMOVAL PROCESSES}

To study the treatability and the fate of each selected organic compound in the industry refinery wastewater treatment process, each characteristic of each compound should be known as presented in Table 4.2.1. Some of these selected organic compounds will be affected by stripping, biological oxidation and adsorption processes.

A series of experiments was designed to investigate the removal of the selected priority pollutants as shown in Figure 5.1

\subsection{Activated Sludge}

The first experiment was to use AS for biological oxidation and to evaluate the effectiveness of the activated sludge in reducing organic pollutant concentrations in the refinery industry wastewater.

Initially, the activated sludge was acclimated to the refinery industry wastewater, and the acclimation period took approximately 4 to 5 weeks. The AS reactor was operated at an HRT of 4 hours. The steady-state condition was judged to have been reached when the effluent substrate concentration became steady over a long period. 


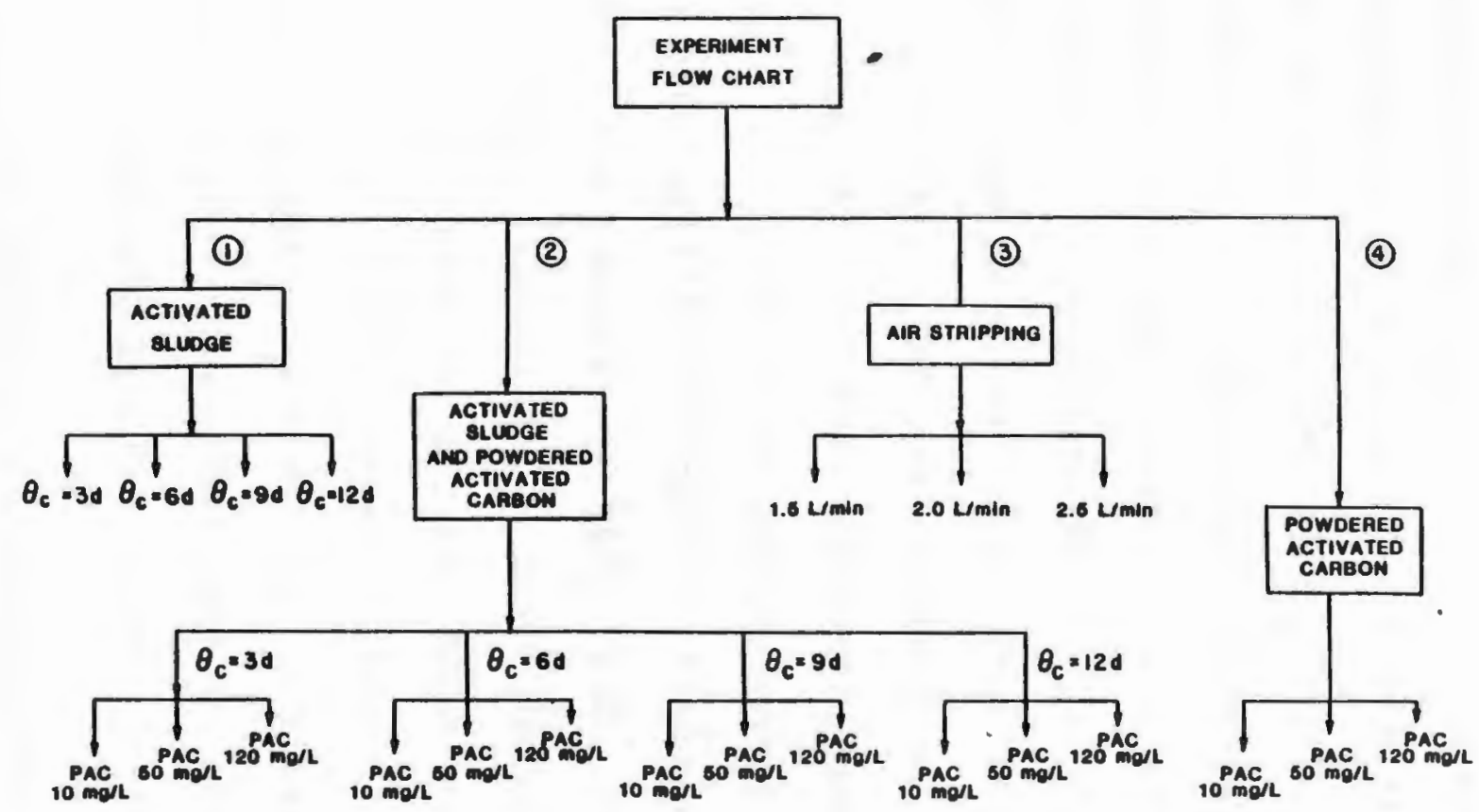

Figure 5.1 Experimental steps 
The aeration reactor tank was continuously fed with wastewater at a rate of $1.31 / \mathrm{h}$ and contained total suspended solids of $114 \mathrm{mg} / 1$. In the aeration reactor tank, the $D O$ was maintained at $5.0 \mathrm{mg} / 1$, and the $\mathrm{pH}$ was kept between 6.80 to 7.20 by adding either $0.25 \mathrm{H}_{2} \mathrm{SO}_{4}$ or $0.5 \mathrm{~N} \mathrm{NaOH}$ to the mixed 1 iquor. The $\theta_{c}$ was kept at 3,6 , 9 and 12 days. For each run, $\theta c$ was controlled by wasting a suitable volume of mixed liquor from the sludge wasting line once per day. Data of interest were collected and analyzed from the influent, effluent, aeration tank and mixed liquor for a period of approximately 5 weeks.

The biological treatment process was examined by determining the removal of $B_{0}, C O D, T O C$ and selected priority organic compounds. Experimental parameters of the pilot plant such as DO, $\mathrm{pH}$, temperature, and sludge retention time (SRT) were measured and recorded. Microscopic examination of the activated sludge was carried out several times each week to observe changes in the concentration and species of microorganisms.

5.2 Integrated Powdered Activated Carbon (PAC) and Activated Sludge (AS)

In this experiment, PAC in a slurry form was introduced into the aeration tank over a period of about two days to reach a constant level for each dosage. 
The amount of carbon that was added to the reactor was calculated as follows:

$$
\frac{W}{N}=D t V
$$

where

$W$ is the weight of carbon, in $\mathrm{mg}$;

$N$ is the number of reactors;

$D$ is the daily carbon dosage, in $\mathrm{mg} / \mathrm{L}$;

$t$ is the number of days until the next sample is taken, and $V$ is the volume of the reactor, in L/reactor.

once the carbon reaches the aeration tank, its concentration increases until equilibrium is reached. The equilibrium carbon concentration in the aeration tank can be calculated, assuming a constant proportion of carbon and sludge in all streams as follows:

$$
c=\frac{{ }^{C_{I} \theta_{c}}}{\theta_{h}}
$$

The PAC experiments investigated 3 carbon dosages $(10,50$, and $120 \mathrm{mg} / 1$ ) at 4 mean cell residence times ( 3 , 6, 9 and 12 days). The HRT time was held constant at 4 hours. A suitable amount of PAC was added once per day to maintain a constant PAC concentration in the system since some PAC was lost in the excess sludge wasting, the clarifier effluent, and the recycling line. The effect of 
each dosage of PAC on the activated sludge biomass and the percentage removal of the selected priority organic pollutants was investigated. Biological growth occurring on PAC was observed. Table 3.3 .1 shows the frequency of sampling. This experiment was run for approximately 60 days.

PAC additions increased the stability of the aeration tank mixed liquor, increased the MLSS concentration, and improved the clarifier effluent quality.

5.3 Air Stripping and Adsorption

A third experiment was conducted to evaluate the stripping and adsorption characteristics of the selected priority pollutants in the absence of biological activity. This part of the study used the same biological pilot plant. Initially, the aeration tank and clarifier unit were cleaned, then the reactor tank and clarifier compartment were filled with distilled water. The refinery industry wastewater was pumped from the feed tank to the aeration tank, at a rate of $1.31 / \mathrm{h}$ to provide a HRT of 4 hours in the activated sludge reactor. The temperature of the reactor was kept at $23^{\circ} \mathrm{C}$ and the $\mathrm{pH}$ at 6.8. The air flow rate was maintained at $21 / \mathrm{h}$. It took about two days for the distilled water to be completely replaced by refinery industry wastewater, as determined by measuring the TOC level as a function of time. The 
experiment was run at air flow rates of $1.5,2.0$, and 2.5 l/hr to observe the stripability of the selected organic compounds, determined by measuring TOC and COD as a function of time and air flow rates. Influent and effluent samples were collected over a 15-day period for analysis. After this experiment was completed, the refinery industry wastewater in the reactor was analyzed to identify the remaining organics

5.4 Integrated Powdered ACtivated Carbon ( $P A C$ ) in the Absence of Activated Sludge

In this experiment, the amounts of TOC, COD and selected priority organic pollutants removed in the activated sludge experiment above were compared with the amounts due to adsorption onto PAC. The 6-L pilot plant reactor was filled with the refinery industry wastewater to the 5.2-L mark and no activated sludge was added. Then the refinery industry wastewater was pumped continuously at a flow rate of $1.3 \mathrm{l} / \mathrm{h}$. The experimental conditions were the same as in the second experiment, but no biomass was added. PAC was added at 10,50 and $120 \mathrm{mg} / 1$, the same concentration as in the second experiment. The pilot plant was operated for 24 hours; then samples were collected for COD, TOC and selected priority organic pollutant analysis. The experiments lasted for two weeks. 


\section{BIOLOGICAL ANALYSIS}

Activated sludge is a mixed biological culture composed mostly of bacteria, protozoans, rotifers and fungi. Bacteria are mostly responsible for degrading the dissolved organic matter in the wastewater to microbial cell tissue and oxidized end products (mainly $\mathrm{CO}_{2}$ and water). However, the protozoans and rotifers are responsible for removing the dispersed bacteria, which have not settied.

The general formulas describing aerobic processes in the AS reactor tank are as follows:

\section{Oxidation}

Biomass $+\mathrm{O}_{2}+$ organic matter $\rightarrow \mathrm{CO}_{2}+\mathrm{NH}_{3}+$ end product (COHNS) + Enêrgy

Synthesis

COHNS + Bacteria + Energy

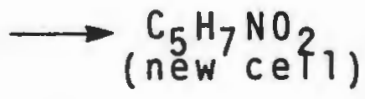

Respiration

$$
\mathrm{C}_{5} \mathrm{H}_{7} \mathrm{NO}_{2}+5 \mathrm{O}_{2} \longrightarrow 5 \mathrm{CO}_{2}+\mathrm{NH}_{3}+2 \mathrm{H}_{2} \mathrm{O}+\text { energy }
$$


To produce the desired effluent quality, the temperature, the reactor basin volume, and the MLSS concentration must be adjusted and carefuliy controlied to achieve high $\mathrm{BOD}_{5}$ and TOC removal.

Also, with refinery industry wastewater entering the reactor tank, the potential exists for inhibition of the AS processes. Heavy metals such as cadmium, chromium, copper, lead, nickel, and zinc react with microorganisms and inhibit their metabolism. Organic compounds also can be toxic to the AS.

In addition, any nutritional deficiency will affect bacterial growth. Therefore, it is important that the concentration of nutrients in the feed line be checked and adjusted if necessary.

\subsection{Initial Biomass Seeding}

The activated sludge was acclimated in the pilot plant by using a mixed liquor seed from the south Kingstown Wastewater Treatment Facility, as described in section 3.5 of this report. The contents of the mixed liquor seed and of samples of the AS were measured as the MLSS and the MLVSS. The AS was sampled every three days after seeding and these are graphed in figure 6.1.1.

In the first three days after seeding, the MLSS and the MLVSS concentration dropped from 2,000 (in the seed) to $380 \mathrm{mg} / 1$ and from 1,800 (in the seed) to $250 \mathrm{mg} / 1$ 


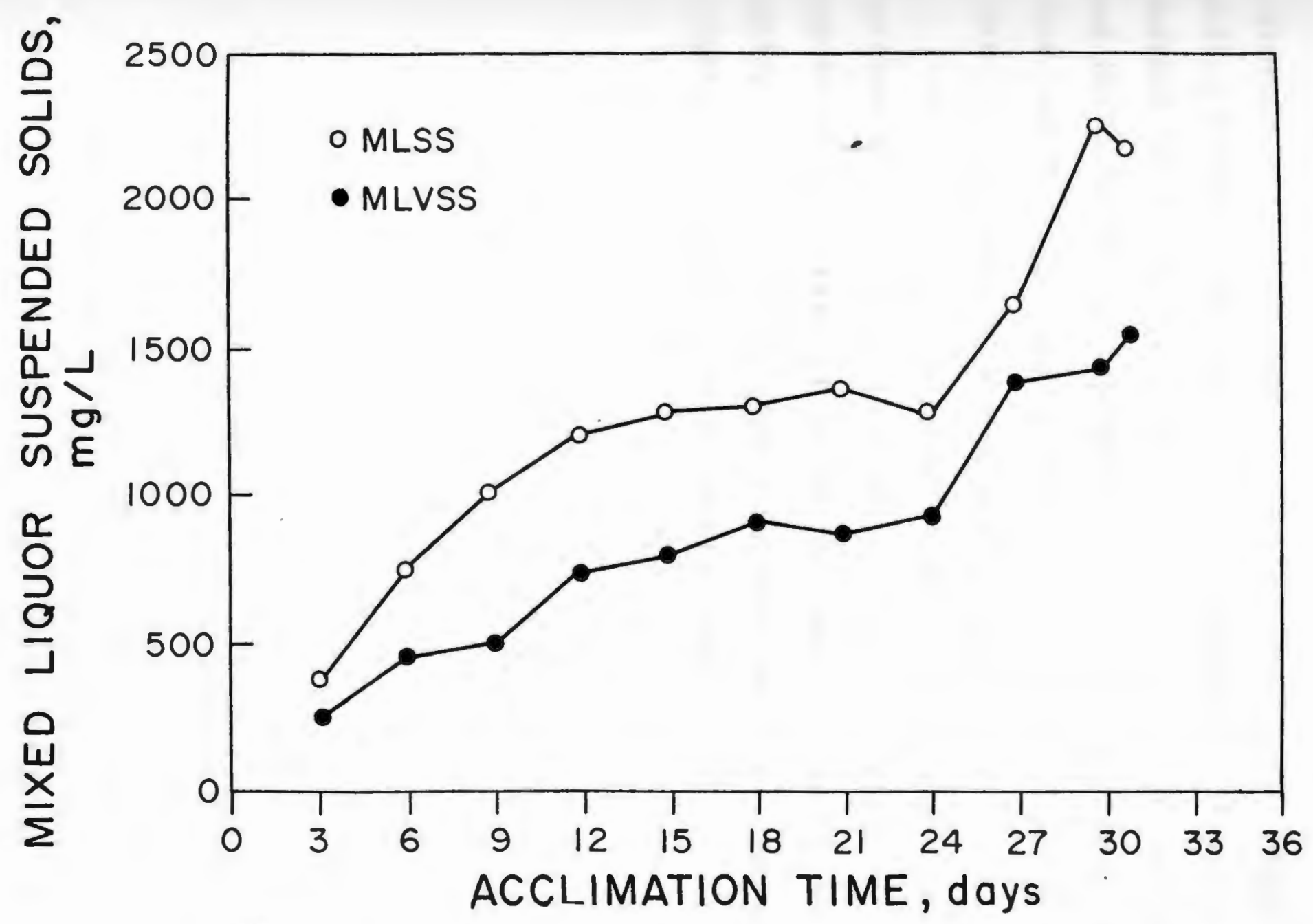

Figure 6.1.1 Suspended Solids Concentration in the Reactor
Unit 
respectively, (Figure 6.1.1). By day 6 after seeding, MLSS and MLVSS increased due to accumulation of bacteria. Between day 6 and day 24, the concentrations of both MLSS and MLVSS gradually increased to a steady concentration. Then both MLSS and MLVSS rose to peak values of $2,200 \mathrm{mg} / \mathrm{L}$ (day 31) and $1,500 \mathrm{mg} / \mathrm{L}$ (day 31), respectively.

After 31 days of operation, the system became acclimated to the refinery waste. The build up of MLSS and MLVSS from days 31 to 64 is shown in Figure 6.1.2; during the activated sludge phase MLSS and MLVSS decreased slightly and then increased fairly steadily. 


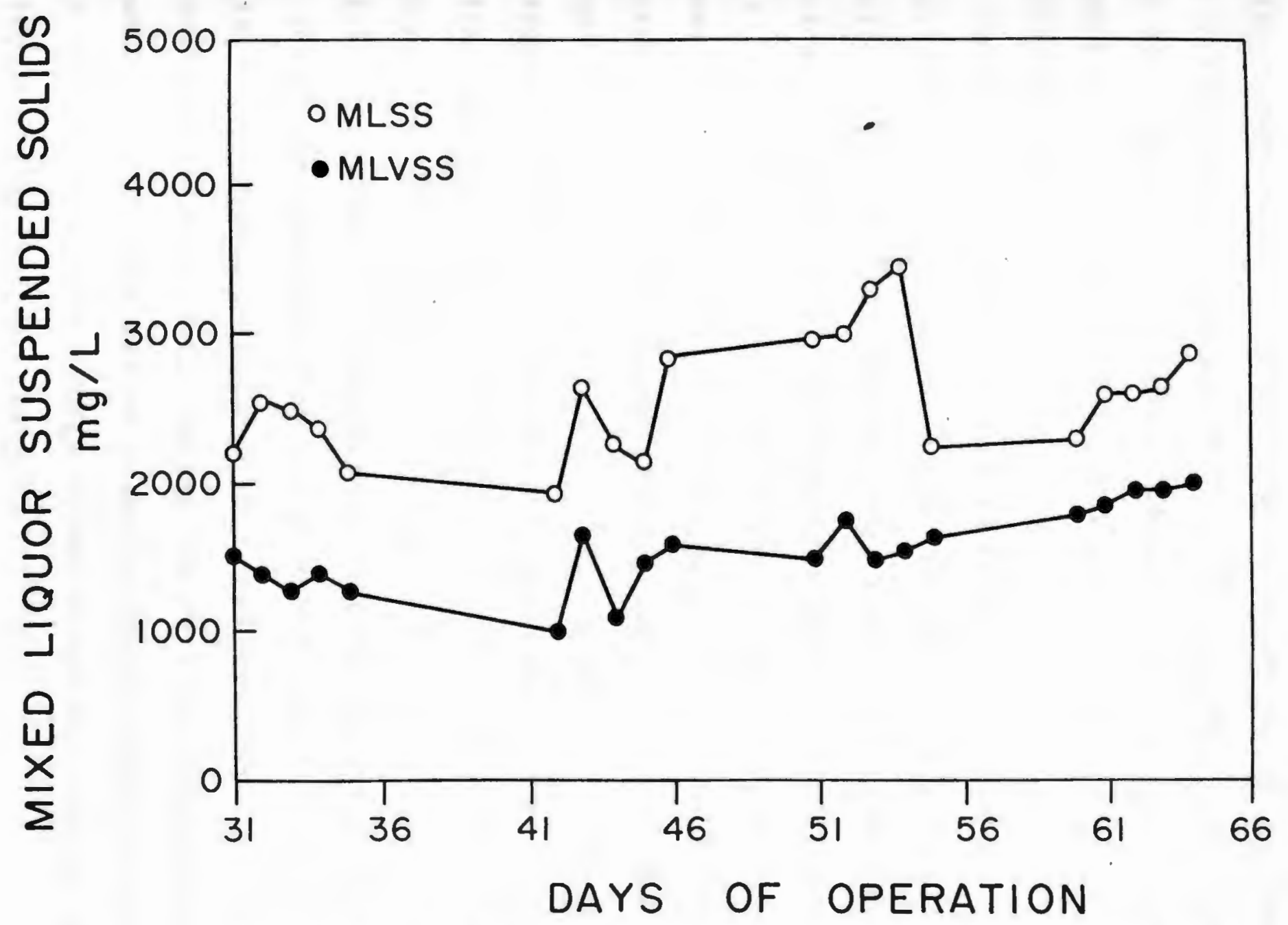

Figure 6.1.2 Aeration Tank suspended Solids Concentration During Activated Sludge Phase 
During the addition of PAC to the AS, the MLSS and MLVSS concentrations in the reactor appeared to increase as sludge age increased for each experiment (Figure 6.1.3). Moreover, a higher concentration of PAC in the reactor may increase the population and the mass of microorganisms.

The TSS and VSS in the clarifier effluent were plotted against the day of operation for 31 to 64 (the AS period; Figure 6.1.4) and for days 64 to 125 (the PAC/AS period; Figure $6 \cdot 7 \cdot 5)$. The concentration of both TSS and vSS increased as the sludge age increased, but not dramatically, the peak TSS 1 evel was $110 \mathrm{mg} / 1$ on day 61 , during the activated sludge phase, while TSS reached a peak of $210 \mathrm{mg} / 7$ on day 83 . This fluctuation in the effluent suspended solids probably occurred as a result of malfunctioning of the internal scraper for the clarifier unit. On the average both the TSS and VSS for the clarifier effluent were maintained between 30 and $60 \mathrm{mg} / 1$. No solids were removed from the system during the first 30 days of operation, except those solids lost from the clarifier effluent unit. During the next two experiments, however, solids were wasted from the sludge wasting point; the amount of wasted sludge depended on the sludge age being maintained in the reactor. 


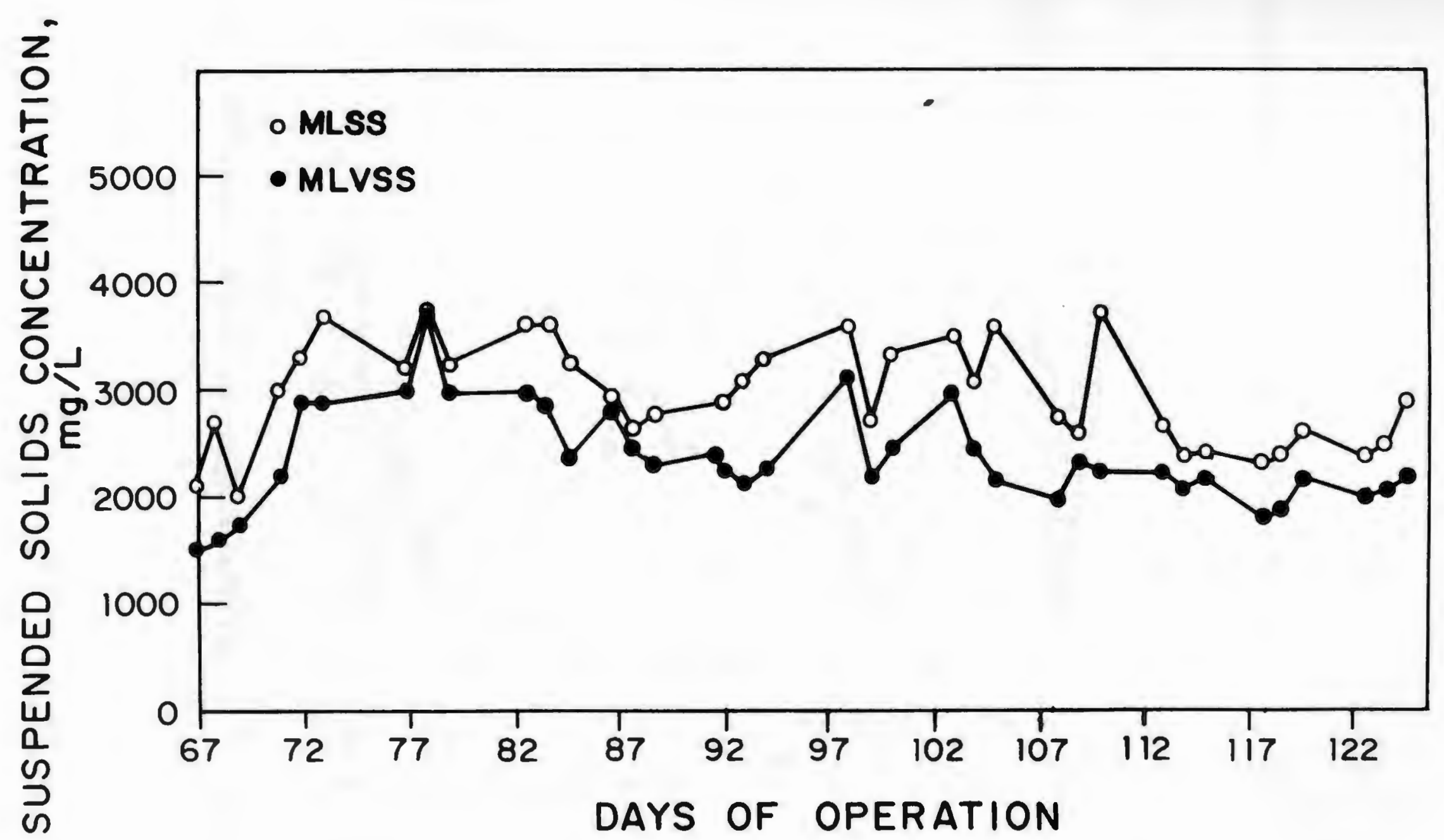

Figure 6.1.3 Areation Tank Suspended Solids During PAC/AS Phase 


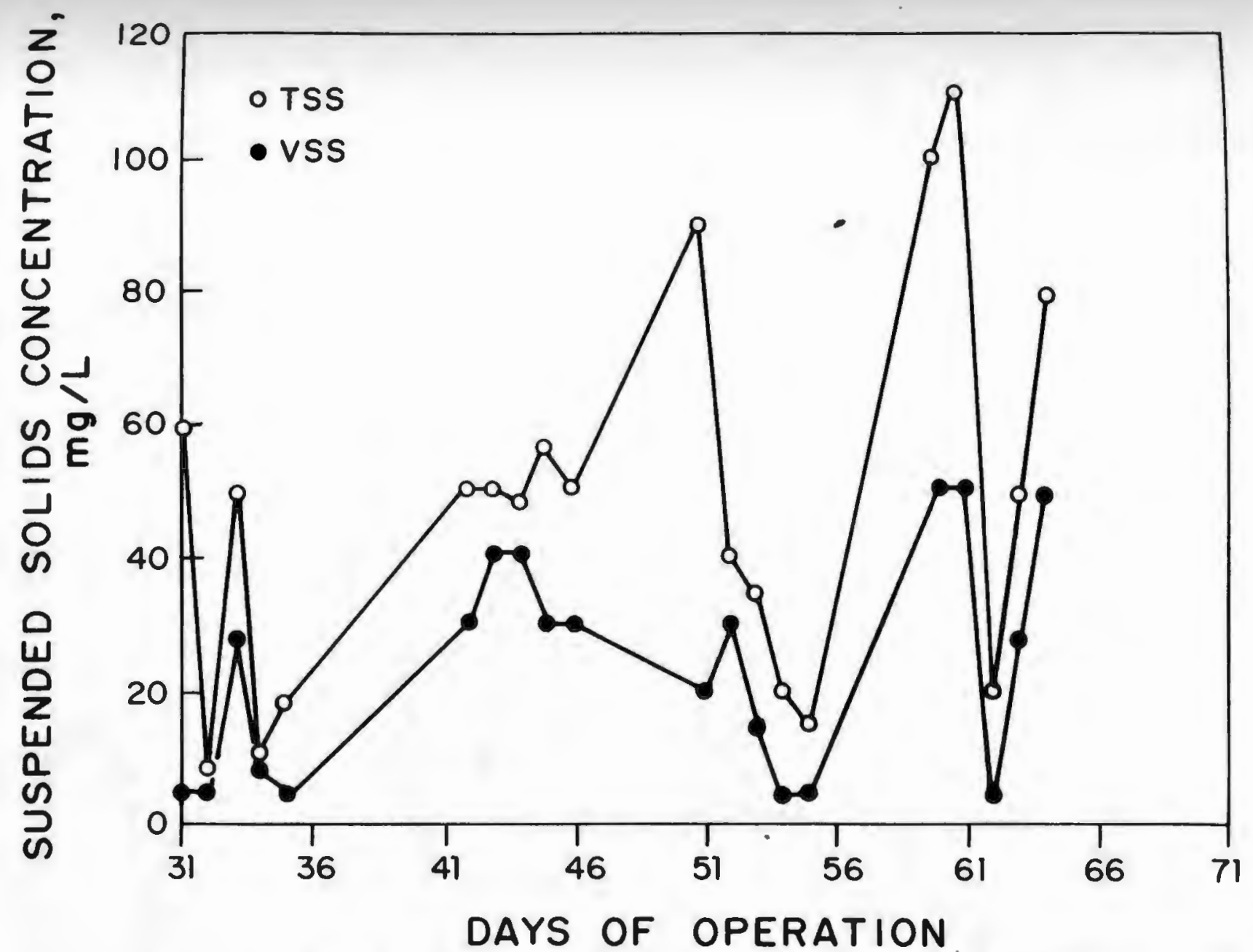

Figure 6.1.4 Clarifier Suspended Solids Effluent During Activated sludge Phase 


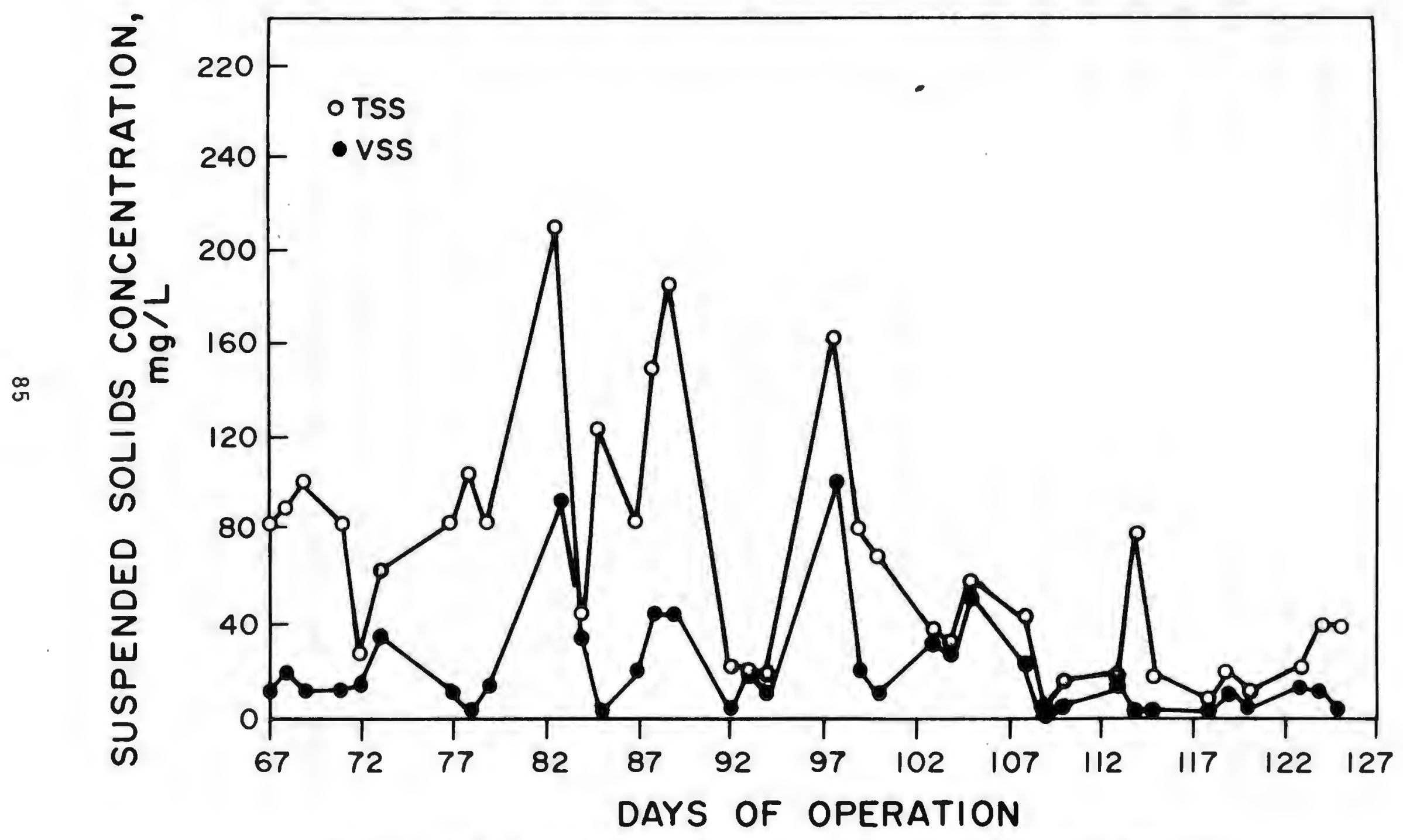
Figure 6.1 .5 Claifier suspended solids Effluent During
PAC/AS Phase 


\subsection{Biological Model}

To come up with a model to describe the biological growth in the AS under the conditions of complete mixing, a typical scheme (shown in Figure 6.2.1) was examined. The influent feed from a holding tank entered the aeration tank and mixed with the recycled sludge from the clarifier. The microorganisms were provided with refinery industry wastewater as a substrate source. The pH was kept in the range of 6.8 to 7.2 and the temperature was kept at $24^{\circ} \mathrm{C}$. The dissolved oxygen concentration was in the range of 5-6 mg/L and nutrients were added as needed. The hydraulic retention time (HRT) was kept at 4 hours; which established a MLSS level of 1500 to $2000 \mathrm{mg} / \mathrm{L}$ (77). Biological activity in the reactor tank reduced the $\mathrm{BOD}_{5}$ concentration, resulting in an increase in bacterial cell numbers (or MLVSS) in the reactor. The solids in the clarifier unit were concentrated in the bottom of the clarifier. A fraction of the solids were recycled to the reactor as a return sludge to keep a constant concentration of MLSS in the reactor. Another fraction was wasted from the system each day from the clarifier underflow to maintain a sludge age of $3,6,9$, and 12 days.

A mass balance for the biomass in the entire system can be written as: 


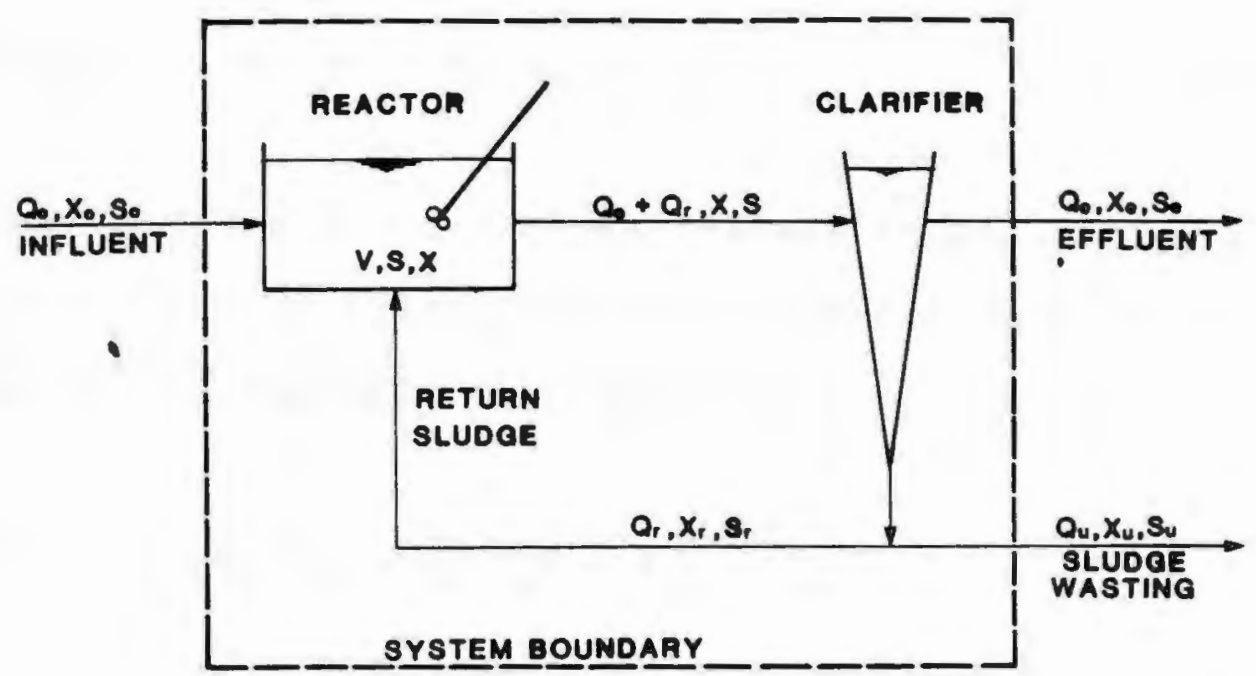

Figure 6.2.1 Complete Mix Activated Sludge Model 
Accumulation of biomass in the system

$$
\begin{aligned}
& \text { Inflow of } \\
& =\text { biomass to } \\
& \text { the system }
\end{aligned}
$$

outflow of

Net growth

- biomass from + of biomass the system the system

The equation for the biomass is:

$$
\frac{d x}{d t} v=Q_{0} x_{0}-\left(Q_{e} x_{e}+Q_{w} x_{w}\right)+v r_{g}^{\prime}
$$

Assuming that the biomass concentration in the influent is zero and that a steady-state condition $(d x / d t=0)$ is reached in the reactor, then Equation 6.2 .1 becomes

$$
0=-\frac{1}{v}\left(Q_{e} x_{e}+Q_{w} x_{w}\right)+r_{g}^{\prime}
$$

or

$$
\frac{1}{V}\left(Q_{e} x_{e}+Q_{w} x_{w}\right)=r_{g}^{\prime}
$$

$r_{g}^{\prime}$ is an expression defined by Metcalf (48):

$$
r_{g}^{\prime}=-r_{s u}-k_{d} X
$$

by definition, then the above equation becomes

$$
\frac{1}{v}\left(Q_{e} x_{e}+Q_{w} x_{w}\right)=-r_{s u}-k_{d} x
$$

Dividing both sides of Equation 6.2 .4 by $x$ yields

$$
\frac{1}{v x}\left(Q_{e} x_{e}+Q_{w} x_{w}\right)=-\frac{Y r_{s u}}{x}-k_{d}
$$

Since

$$
\frac{1}{\theta_{c}}=-\frac{Y r_{s u}}{X}-k_{d}
$$


By definition, then Equation 6.2 .5 becomes

$\frac{1}{\theta_{c}}=\frac{1}{\nabla} x\left(Q_{e} x_{e}+Q_{w} x_{w}\right)$

This equation can be rearranged to yield

$$
\theta_{c}=\frac{v x}{\left(Q_{e} x_{e}+Q_{w} x_{w}\right)}
$$

However, the biomass in the effluent is very small compared to the biomass at other points in the system. Therefore,

$$
\theta_{c}=\frac{v X}{Q_{w} X_{w}}
$$

where $\dot{\theta}_{c}$ is called the mean cell residence time or sludge age .

Another important parameter in the design and operation of the reactor is the efficiency, defined as:

$$
\text { Effy }=\frac{\left(S_{0}-S_{e}\right)}{S_{0}} \times 100 \%
$$




\subsection{Biokinetic Constants}

In a biological system where all environmental needs are provided the bacteria will increase in number. The growth rate can be expressed as:

$$
\frac{d x}{d t}=r_{g}=u x
$$

Metcalf (48) showed that there are relationships between substrate nutrients for the microorganisms to grow. In a continuous culture, however, the growth of microorganisms can be limited to show the limiting effect of nutrients on substrate. This growth can be described as follows:

$$
u=\frac{u_{m} s}{s+k_{s}}
$$

When the activated sludge was operated under steady conditions, the biological growth rate equaled the rate of biomass losses in the effluent and waste sludge. If $U$ is inserted as the symbol for specific substrate utilization, $-r_{s u} / x$, in Equation 6.2 .6 the equation becomes a

$$
\frac{1}{\theta_{c}}=Y U-k_{d}
$$

At steady state conditions, the substrate utilization rate, $r_{s u}$, and the specific substrate utilization rate, $U$, are constants and could be defined as:

$$
r_{s u}=-\frac{s_{0}-s_{e}}{\theta_{h}}
$$


Thus,

$$
u=-\frac{r_{s u}}{x}=\frac{s_{0}-s_{e}}{\theta_{h} x}
$$

Substituting $\frac{\left(S_{0}-S_{e}\right)}{\theta_{h} X}$ for $U$ in Equation 6.3 .3

yields

$$
\frac{1}{\theta_{c}}=Y \frac{\left(S_{0}-S_{e}\right)}{\theta_{h} X}-k_{d}
$$

plotting $\frac{{ }^{\prime}}{\theta_{c}}$ against $\frac{\left(S_{0}-S_{e}\right)}{\theta_{h} x}$ one obtains a straight line with slope $Y$ and intercept $k_{d}$.

The term $u_{m}$ in Equation 6.3.2 can be defined as:

$$
u_{m}=k Y
$$

If the value of $u$ from Equation 6.3 .1 is substituted in Equation 6.3.2, the resulting expression for the rate of growth is

$$
r_{g}=\frac{u_{m} s x}{k_{s}+s}
$$

Metcalf (48) showed that because of the quantity of new cells produced for a given substrate, the following relationships have been developed between the rate of substrate utilization and the rate of growth as follows:

$$
r_{g}=-Y r_{s u}
$$


The terms $r_{g}$ in Equation 6.3 .8 is substituted in Equation 6.3.9; the rate of substrate utilization can be defined as follows:

$$
r_{s u}=-\frac{u_{m}}{y} \frac{x s}{\left(k_{s}+s\right)}
$$

In Equation 6.3 .10 the term $u_{m} / Y$ is replaced by the term $k$, and $S$ equals to $S_{e}$; then

$$
r_{s u}=-\frac{k \times s_{e}}{\left(k_{s}+s_{e}\right)}
$$

Substituting :

$$
\begin{aligned}
& -\frac{\left(s_{0}-s_{e}\right)}{\theta_{h}} \text { for } r_{s u} \text { in Equation } 6.3 .11 \text { gives } \\
& \frac{s_{0}-s_{e}}{\theta_{h}}=\frac{k \times S_{e}}{k_{s}+s_{e}}
\end{aligned}
$$

Dividing both sides by $x$ yields

$$
\frac{s_{0}-s_{e}}{\theta_{h} X}=\frac{k s_{e}}{k_{s}+s_{e}}
$$

Taking the inverse of Equation 6.3 .13 gives

$$
\frac{\theta_{h} x}{s_{0}-s_{e}}=\frac{k_{s}}{k s_{e}}+\frac{s_{e}}{k s_{e}}
$$

or

$$
\frac{\theta_{h} x}{s_{0}-s_{e}}=\frac{k_{s}}{k} \quad \frac{1}{s_{e}}+\frac{1}{k}
$$

By plotting $\frac{\theta_{h} X}{S_{0}-S_{e}}$ vs. $\frac{1}{S_{e}}$ one obtains a straight line 
with slope $\frac{k_{s}}{k}$ and intercept $\frac{1}{k}$.

6. 4 Determination of Kinetic Coefficients.

The value of the kinetic coefficient $k$, the maximum rate of substrate utilization per unit mass of microorganisms (day -1 ); $K_{S}$, the half-velocity constant ( $m g / L$ of $\mathrm{BOD}_{5}$ or $\mathrm{COD}$ or TOC); $\mathrm{k}_{d}$, the endogenous decay coefficient (day-1); and Y, the maximum yield coeffiencient (day ${ }^{-1}$ ) were determined for both the AS experiment and the experiment in which PAC was added to the AS. The procedure was to operate the reactor at different MLVSS concentrations in the range of $1500-3000$ $\mathrm{mg} / \mathrm{L}$ at several sludge ages $(3,6,9$, and 12 days) under steady-state conditions. Temperature, pH, dissolved oxygen concentration and $\theta$ were held constant throughout the experiments. The average values of 1 ) flow rates (0), 2) influent $B O D_{5}, C O D$ and TOC as $S_{0}, 3$ ) effiuent $B O D_{5}, C O D$ and TOC and as $S_{e}$, and 4) the concentrations of the biomass in the reactor as $x$ were determined through frequent measurements. From the data obtained, the sludge age $\left(\theta_{c}\right)$ was calculated by Equation 6.2 .9 and $U$ values were obtained by Equation 6.3 .5 . By substituting these values into Equations 6.3 .6 , and 6.3 .14 the biokinetic constants were determined. 
6.5 Microscopic Analysis of Activated Sludge 6.5.1 Materials and Methods

A Zeiss photomicroscope was used at a magnification level of $160 x$ and a phase contrast of $40 x / 1.25$ to examine AS samples for the presence of microorganisms either attached to other cells or as free swimmers in the solution. Five samples (each about $2 \mathrm{ml}$ ) were collected directly from the reactor and placed in $5 \mathrm{ml}$ test tubes. It was important to fill each test tube less than halfway to allow adequate air space. Immediately after collection, the sample was analyzed, beginning with $160 x$ phase contrast microscopy, which requires only a small volume of sample (< $1 \mathrm{ml})$. Each sample was placed on a glass slide and covered with a thin glass cover; no special preparation such as staining was required. The sample was examined at a magnification of $160 x$ for the types, relative amounts, and growth of microorganisms in the AS. No attempt was made in this study to estimate the total number or the sizes of each microorganism.

6.6 Biogrowth on Powdered Activated Carbon (PAC)

The PAC surfaces are excellent sites for microorganisms to grow on. The PAC surfaces enrich the concentration of organic compounds as well as provide 
excellent places for microorganisms to be protected from fluid shear forces. As reported in previous studies, 130 , $41,80)$, biological growth on PAC improved the removal efficiency of organic compounds found in refinery industry wastewater. Thus, microorganisms in the reactor can oxidize certain organic compounds on the surfaces of PAC particles and this reduces the organic concentrations and the organic loading on the carbon. Formation of a biofilm on the carbon particles may affect the adsorption rate; therefore, the biomass may act as a barrier and, in the end, reduce the transport rate of dissolved organics to the carbon surface (81). Scanning electron microscopy (SEM) was used as a tool to examine the carbon particles and to observe the relationships between the PAC and the attached growth. Thus, one could observe the type of organisms and the attachment structures that the organisms could build on the carbon particles (82).

\subsubsection{Materials and Methods}

In this experiment, PAC type BL (Calgon Corporation) was used. (For more information, see Table 3.1.1). PAC was added to the reactor in a slurry form. Carbon particle samples were collected directly from the reactor under conditions of complete mixing. At the time of sample collection, the reactor had PAC concentrations of 50 and $120 \mathrm{mg} / \mathrm{L}$. No samples were collected for PAC 
particles at a reactor concentrations of $10 \mathrm{mg} / \mathrm{L}$, because the biogrowth mass on the PAC particles was not abundant. After collection, the carbon samples were removed and fixed, as described below.

The collected samples were fixed and prepared for scanning electron microscopy $(30,41,80)$. The PAC particles were immersed for two hours in $2 \mathrm{ml}$ of a 70:30 mixture of $2.5 \%$ glutaraldehyde and $\mathrm{pH} 7.3$ buffer solution. The carbon samples were then transferred into 0.1 M sodium phosphate buffer ( $\mathrm{PH} 7.3)$ for one hour. Excess buffer solution was removed from the PAC particle samples, but a small amount was left to cover the specimen; the sample was then kept in a refrigerator at $4^{\circ} \mathrm{C}$ until the next step, fixation. The carbon particle samples were resuspended in $2 \%$ osmium oxide $\left(\mathrm{OsO}_{4}\right)$ in $0.1 \mathrm{M}$ sodium phosphate buffer (PH 7.3) for 3 hours. Then the PAC particles were washed five time with ethanol $(50,70,80$, 90 and 100\%). Samples were dried in a 1:1 100\% ethanol amylacetate solution and stored for 24 hours in amy 1 ace tate.

A DCP - L critical point dryer was used to dry the fixed samples. Then the PAC particles were mounted on aluminum stubs and coated with gold to increase the conductivity of the biological materials. The PAC particle samples were examined in a scanning electron microscope at 20-25 KV with a resolution of $10 \mathrm{~nm}$. For 
control samples (virgin carbon), the fixation, dehydration and drying steps were eliminated; the carbon particle samples were glued to the stubs and then coated with gold (about $2 \mathrm{~nm}$ thick) before SEM. 


\section{RESULTS}

7.1 Description and Evaluation of Biokinetic Constants

Using the data from the reactor, plots were made to determine the biokinetic constants of the refinery industry wastewater.

The biokinetic constants were defined in terms of $B O D_{5}, C O D$ and $T O C$. Each constant was obtained for the first two experiments with AS alone at first and then with the addition of PAC to the AS. The linearization of the experimental data collected is presented in Figures A.2.1 - A.2.24 in Appendix 2. The data were scattered around the best-fit line. This scattering of the data is typical of this type of analysis. The lines were drawn using the least square method. The straight-line analysis yielded $k, K_{S}, k_{d}$ and $Y$ according to Equations 6.3 .6 and 6.3 .14 .

Table 7.1.1 presents the biokinetic constants in terms of $\mathrm{BOD}_{5}, \mathrm{COD}$ and $T O C$, which are considered to be the substrate concentration in the reactor. The MLVSS are used as a measure of microbial solids concentrations. The values of the biokinetic constants for the wastewater (Table 7.1.1) were different from typical values (Table 7.1.2). 
Table 7.1.1 Biokinetic Constants for the Modified Activated Sludge Pilot Plant

\begin{tabular}{|c|c|c|c|c|c|}
\hline Constant & Units & $\begin{array}{l}\text { PAC Con- } \\
\text { centrations } \\
(\mathrm{mg} / \mathrm{L})\end{array}$ & $\mathrm{BOD}_{5}$ & COD & TOC \\
\hline$k$ & $\mathrm{day}^{-1}$ & $\begin{array}{r}0 \\
10 \\
50 \\
120\end{array}$ & $\begin{array}{l}2 \\
2 \\
0.65 \\
0.82\end{array}$ & $\begin{array}{l}2.40 \\
2.50 \\
1.33 \\
1.80\end{array}$ & $\begin{array}{l}0.18 \\
1.0 \\
0.75 \\
0.64\end{array}$ \\
\hline$k_{s}$ & $\begin{array}{l}\mathrm{mg} / \mathrm{L} \quad \mathrm{BOD}_{5} \\
\text { or } \mathrm{COD}\end{array}$ & $\begin{array}{r}0 \\
10 \\
50 \\
120\end{array}$ & $\begin{array}{l}75 \\
13 \\
15 \\
33\end{array}$ & $\begin{array}{r}80 \\
40 \\
89 \\
4\end{array}$ & $\begin{array}{r}7.2 \\
24.0 \\
30.0 \\
16.0\end{array}$ \\
\hline$k_{d}$ & $\mathrm{day}^{-1}$ & $\begin{array}{r}0 \\
10 \\
50 \\
120\end{array}$ & $\begin{array}{l}0.42 \\
0.14 \\
0.22 \\
0.28\end{array}$ & $\begin{array}{l}0.46 \\
0.20 \\
0.46 \\
0.04\end{array}$ & $\begin{array}{l}0.59 \\
0.15 \\
0.32 \\
0.34\end{array}$ \\
\hline$Y$ & $\begin{array}{c}\mathrm{mg} \text { VSS per } \\
\mathrm{mg} \mathrm{BOD}_{5} \text { or } \\
\mathrm{COD}^{2}\end{array}$ & $\begin{array}{r}0 \\
10 \\
50 \\
120\end{array}$ & $\begin{array}{l}1.00 \\
1.00 \\
2.50 \\
1.2\end{array}$ & $\begin{array}{l}0.62 \\
0.33 \\
0.80 \\
0.60\end{array}$ & $\begin{array}{l}0.86 \\
0.83 \\
0.80 \\
1.00\end{array}$ \\
\hline
\end{tabular}


Table 7.1.2 Typical Values for Biokinetic Constants for the Activated Sludge at $20^{\circ} \mathrm{C}$ (Ref no. 48).

\begin{tabular}{llcl} 
Constant & Units & Range & $\begin{array}{c}\text { Typical } \\
\text { Value }\end{array}$ \\
\hline $\mathrm{k}$ & $\mathrm{day}^{-1}$ & $2-10$ & 5.0 \\
$\mathrm{~K}_{\mathrm{s}}$ & $\mathrm{mg} / \mathrm{L} \mathrm{BOD}$ & $25-100$ & 60 \\
$\mathrm{mg} / \mathrm{L} \mathrm{COD}$ & $15-70$ & 40 \\
$\mathrm{k}_{\mathrm{d}}$ & $\mathrm{day}^{-1}$ & $0.04-0.075$ & 0.06 \\
$\mathrm{Y}$ & $\mathrm{mg}$ VSS/mg BOD & $0.4-0.8$ & 0.6 \\
& $\mathrm{mg}$ VSS/mg COD & $0.25-0.4$ & 0.4 \\
\hline
\end{tabular}


The AS results for $k$ measurements falls outside the range. $K_{s}$ tend to fall within the range of 1 iterature and the values for $k_{d}$ and $Y$ are higher than typical values.

The high value of $Y$ suggests high rates of sludge production. As can be observed in Table 7.1.1, biokinetic constants can differ from typical values for two possible reasons; 1) the biokinetic constant values depend on the type of wastewater, and 2) the values of the biokinetic constants'depend entirely on the operating conditions of the reactor, such as temperature, sludge age and carbon dosages $(24)$.

PAC present in the reactor has an effect on the value of the biokinetic constants. The presence of PAC can reduce the concentration of the $A S$; therefore, the kinetic values calculated with PAC would be less than the typical literature values for AS without PAC additions. Also, the biomass activity which occurs in the PAC pores is controlled by the substrate mass transfer into the pores (60). 
7.2 Experiment 1: Activated Sludge Treatment Process

A series of experiments were carried out at sludge ages of $3,6,9$ and 12 days. Each experiment lasted at least 5 days under steady state conditions. The hydraulic retention time (HRT) was kept at 4 hours for the duration of the test program. Ammonium sulfate and potassium phosphate were added as nutrient sources ( $N$ and $P$ ).

Experiment 1 was conducted at a sludge age $\left(\theta_{C}\right)$ of 3 days. Table 7.2.1 summarizes the biological treatment experimental findings when the MLSS was about $2,198 \mathrm{mg} / \mathrm{L}$ and the MLVSS was about $1,300 \mathrm{mg} / \mathrm{L}$. Other parameters such as $\mathrm{NH}_{3}, \mathrm{NO}_{2}, \mathrm{NO}_{3}$ phosphate and $0 \mathrm{il} / \mathrm{grease}$ were determined. Biological parameters were al so determined for sludge ages of 6,9 , and 12 days, (Tables $7.2 .2-4$, respectively). These data show increases in the MLVSS and MLSS concentrations as the sludge age increases. This is due to 1) increases in the activity of the biomass in the reactor and 2) the fact that the amount of wasted sludge was less than at a 3-day sludge age. 
Table 7.2.1 Biological Treatment of Refinery Industry Wastewater by Activated Slydge, Sludge Age $\left(\theta_{c}\right)=3$ days (Al1 concentrations are in $\mathrm{mg} / \mathrm{L}$ )

\begin{tabular}{|c|c|c|c|c|c|c|c|c|c|c|c|c|c|c|c|c|c|}
\hline \multirow[b]{2}{*}{1986} & \multirow[b]{2}{*}{ No. } & \multicolumn{4}{|c|}{ Supended Solids } & \multicolumn{2}{|c|}{$\mathrm{NH}_{3}$} & \multicolumn{2}{|c|}{$\mathrm{NO}_{2}$} & \multicolumn{2}{|c|}{$\mathrm{NO}_{3}$} & \multicolumn{2}{|c|}{$\begin{array}{c}\text { Total } \\
\text { Phosphate }\end{array}$} & \multicolumn{2}{|c|}{$\begin{array}{l}\text { Ortho- } \\
\text { Phosphate }\end{array}$} & \multicolumn{2}{|c|}{ Oil and Grease } \\
\hline & & MVSS & MLss & vSS & TSS & Inft & Efft & Inft & Efft & Inft & Efft & Inft & Efft & Inft & Efft & Inft & Efft \\
\hline $8 / 31$ & 1 & 1,520 & 2,196 & 5 & 60 & 35 & 30 & 0.20 & 0.07 & 0.54 & 0.06 & 3.0 & 0.17 & 2.20 & 1.22 & 191 & 127 \\
\hline $9 / 1$ & 2 & 1,420 & 2,584 & 5 & 8 & 43 & 32 & 0.32 & 0.03 & 0.61 & 0.16 & 2.0 & 0.04 & 1.79 & 0.66 & 28 & 6 \\
\hline $9 / 2$ & 3 & 1,560 & 2,492 & 28 & 50 & 30 & 20 & 0.28 & 0.02 & 0.20 & 0.07 & 3.0 & 0.02 & 2.44 & 0.43 & 33 & 7 \\
\hline $9 / 3$ & 4 & $.1,380$ & 2,370 & 9 & 10 & 24 & 8 & 0.46 & 0.02 & 1.32 & 0.38 & 0.94 & 0.67 & 0.27 & 0.20 & 61 & 15 \\
\hline $9 / 4$ & 5 & 1,300 & 2,198 & 5 & 18 & 30 & 7 & 0.40 & 0.02 & 0.50 & 0.05 & 0.22 & 0.20 & 1.50 & 0.15 & 81 & 8 \\
\hline
\end{tabular}


Table 7.2.2 Biological Treatment of Refinery Industry Wastewater by Activated Sludge, Sludge Age $\left(\theta_{c}\right)=6$ days (All concentraions are in $\mathrm{mg} / \mathrm{L}$ ).

\begin{tabular}{|c|c|c|c|c|c|c|c|c|c|c|c|c|c|c|c|c|c|}
\hline \multirow[b]{2}{*}{1986} & \multirow[b]{2}{*}{ No. } & \multicolumn{4}{|c|}{ Supended Solids } & \multicolumn{2}{|c|}{$\mathrm{NH}_{3}$} & \multicolumn{2}{|c|}{$\mathrm{NO}_{2}$} & \multicolumn{2}{|c|}{$\mathrm{NO}_{3}$} & \multicolumn{2}{|c|}{$\begin{array}{c}\text { Total } \\
\text { Phosphate }\end{array}$} & \multicolumn{2}{|c|}{$\begin{array}{l}\text { Ortho- } \\
\text { Phosphate }\end{array}$} & \multicolumn{2}{|c|}{$0 i 1$ and trease } \\
\hline & & MVSS & MSS & vss & TSS & Inft & Efft & Inft & Efft & Inft & Efft & Inft & Efft & Inft & Efft & Inft & Efft \\
\hline $9 / 11$ & 6 & 1,020 & 1,918 & 30 & 50 & 15 & 3 & 0.90 & 0.13 & 0.7 & 0.46 & 3.46 & 0.58 & 1.88 & 0.27 & 52 & 30 \\
\hline $9 / 12$ & 7 & 1,620 & 2,640 & 40 & 50 & 20 & 8 & 0.40 & 0.10 & 0.11 & 0.20 & 3.76 & 0.40 & 1.32 & 0.32 & 54 & 46 \\
\hline $9 / 13$ & 8 & 1,120 & 2,250 & 40 & 48 & 23 & 10 & 0.50 & 0.16 & 0.32 & 0.08 & 3.11 & 0.04 & 0.10 & 0.01 & 68 & 61 \\
\hline $9 / 14$ & 9 & 1,480 & 2,674 & 30 & 56 & 32 & 21 & 0.60 & 0.14 & 1.49 & 0.65 & 3.25 & 0.62 & 0.46 & 0.38 & 65 & 28 \\
\hline $9 / 15$ & 10 & 1,596 & 2,840 & 30 & 50 & 32 & 17 & 0.70 & 0.10 & 3.18 & 0.04 & 3.07 & 0.72 & 0.16 & 0.08 & 116 & 71 \\
\hline
\end{tabular}


Tab7e 7.2.3 Biological Treatment of Pefinery Industry Wastewater by Activated Sludge, Sludge Age $\left(\theta_{C}\right)=9$ days (All concentrations are in $\mathrm{mg} / \mathrm{L}$ ).

\begin{tabular}{|c|c|c|c|c|c|c|c|c|c|c|c|c|c|c|c|c|c|}
\hline \multirow[b]{2}{*}{1986} & \multirow[b]{2}{*}{ No. } & \multicolumn{4}{|c|}{ Supended Solids } & \multicolumn{2}{|c|}{$\mathrm{NH}_{3}$} & \multicolumn{2}{|c|}{$\mathrm{NO}_{2}$} & \multicolumn{2}{|c|}{$\mathrm{NO}_{3}$} & \multicolumn{2}{|c|}{$\begin{array}{c}\text { Total } \\
\text { Phosphate }\end{array}$} & \multicolumn{2}{|c|}{$\begin{array}{l}\text { Ortho- } \\
\text { Phosphate }\end{array}$} & \multicolumn{2}{|c|}{ Oil and Grease } \\
\hline & & MVSS & MSS & vSS & TSS & Inft & Efft & Inft & Efft & Inft & Efft & Inft & Efft & Inft & Efft & Inft & Efft \\
\hline $9 / 20$ & 11 & 1,500 & 2,980 & 20 & 90 & 44 & 30 & 0.08 & 0.04 & 1.20 & 0.68 & 1.35 & 0.70 & 0.14 & 0.12 & 30 & 21 \\
\hline 9/21 & 12 & 1,760 & 3,000 & 30 & 40 & 40 & 33 & 0.18 & 0.04 & 0.16 & 0.02 & 4.62 & 0.76 & 2.64 & 1.98 & 50 & 19 \\
\hline 9/22 & 13 & 1,500 & 3,300 & 15 & 35 & 15 & 3 & 0.12 & 0.02 & 0.80 & 0.16 & 4.14 & 0.28 & 2.64 & 1.14 & 92 & 40 \\
\hline 9/23 & 14 & 1,540 & 3,460 & 5 & 20 & 20 & 1 & 0.16 & 0.02 & 0.40 & 0.03 & 3.16 & 0.01 & 1.18 & 1.51 & 15 & 3 \\
\hline $9 / 24$ & 15 & 1,640 & 2,220 & 5 & 15 & 10 & 1 & 0.20 & 0.14 & 1.36 & 0.72 & 5.30 & 0.48 & 3.60 & 1.80 & 62 & 27 \\
\hline
\end{tabular}


Table 7.2.4 Biological Treatment of Refinery Industry Wastewater by Activated Slüdge, Sludge Age $\left(\theta_{c}\right)=12$ days (All concentraions are in $\mathrm{mg} / \mathrm{L}$ ).

\begin{tabular}{|c|c|c|c|c|c|c|c|c|c|c|c|c|c|c|c|c|c|}
\hline \multirow[b]{2}{*}{1986} & \multirow[b]{2}{*}{ No. } & \multicolumn{4}{|c|}{ Supended Sol ids } & \multicolumn{2}{|c|}{$\mathrm{NH}_{3}$} & \multicolumn{2}{|c|}{$\mathrm{NO}_{2}$} & \multicolumn{2}{|c|}{$\mathrm{NO}_{3}$} & \multicolumn{2}{|c|}{$\begin{array}{c}\text { Total } \\
\text { Phosphate }\end{array}$} & \multicolumn{2}{|c|}{$\begin{array}{l}\text { Ortho- } \\
\text { Phosphate }\end{array}$} & \multicolumn{2}{|c|}{ oil and grease } \\
\hline & & Muss & MSS & vSS & TSS & Inft & Efft & Inft & Efft & Inft & Efft & Inft & Efft & Inft & Efft & Inft & Efft \\
\hline 9/29 & 16 & 1,580 & 1,800 & 50 & 100 & 13 & 1 & 0.46 & 0.20 & 1.12 & 0.60 & 3.14 & 0.07 & 1.50 & 0.52 & 15 & 2 \\
\hline 9/30 & 17 & 1,596 & 1,850 & 50 & 110 & 11 & 0 & 0.36 & 0.01 & 0.57 & 0.48 & 3.63 & 0.65 & 2.40 & 1.18 & 63 & 20 \\
\hline $10 / 1$ & 18 & 1,920 & 1,940 & 5 & 20 & 12 & 1 & 0.60 & 0.04 & 1.04 & 0.60 & 1.52 & 0.01 & 1.60 & 0.42 & 10 & 3 \\
\hline $10 / 2$ & 19 & 1,960 & 2,672 & 28 & 50 & 50 & 34 & 0.36 & 0.04 & 0.77 & 0.39 & 2.21 & 0.35 & 1.53 & 0.44 & 18 & 1 \\
\hline $10 / 3$ & 20 & 2,040 & 2,890 & 50 & 81 & 43 & 42 & 0.04 & 0.02 & 1.10 & 0.50 & 1.12 & 0.10 & 1.47 & 0.30 & 45 & 12 \\
\hline
\end{tabular}


Tables 7.2.5-8 show the calculated results of experiment 1. The $B O D_{5}$ concentration in the effluent was in the average of $24 \mathrm{mg} / \mathrm{L}$, giving a reduction in $B O D_{5}$ of about $80 \%$. Figure 7.2 .1 shows the variation in the influent and effluent $\mathrm{BOD}_{5}$ concentrations throughout the test period. In general, the reduction in $B O D_{5}$ was about $80 \%$. Even though the experiment was run at different sludge ages, the reduction in the $\mathrm{BOD}_{5}$ concentration was almost the, same. This demonstrated that typical biological treatment will remove approximately $80 \% \mathrm{BOD}_{5}$ for this waste. A greater reduction would be seen if the influent $\mathrm{BOD}_{5}$ concentration was consistent during the test period. The variation in the feed composition will affect the biomass activities to reduce $\mathrm{BOD}_{5}$ concentration. However if the feed composition was low, the percent of $\mathrm{BOO}_{5}$ removal would be high, and all substrate utilization would occur in the reactor. Another factor which can contribute to lower $\mathrm{BOD}_{5}$ removals is the oxygen demand exerted by high concentrations of organic pollutants.

Figure 7.2.2 shows the changes in the strength of TOC throughout the test period. The decline in TOC strength could be a result of concentration reduction in chemical compounds in the stored industrial wastewater. As can be seen from the results shown in Tables 7.2.5-8, biological treatment could achieve as high as $80 \%$ reduction with a TOC concentration in the effluent of 1 ess than $25 \mathrm{mg} / \mathrm{L}$. 
Table 7.2.5 Activated Sludge Performance in Experiment 1 Sludge Age $(\theta c)=3$ days

\begin{tabular}{|c|c|c|c|c|c|c|c|c|c|}
\hline \multirow[b]{2}{*}{$\begin{array}{l}\text { Run } \\
\text { No. }\end{array}$} & \multicolumn{3}{|c|}{$\mathrm{BOD}_{5}$} & \multicolumn{3}{|c|}{ COD } & \multicolumn{3}{|c|}{ TOC } \\
\hline & $\begin{array}{c}\operatorname{Inft} \\
(\mathrm{mg} / \mathrm{L})\end{array}$ & $\begin{array}{r}E f f t \\
(m g / L)\end{array}$ & $\begin{array}{l}\text { Effy } \\
(\%)\end{array}$ & $\begin{array}{c}\operatorname{Inft} \\
(\mathrm{mg} / \mathrm{L})\end{array}$ & $\begin{array}{c}\text { Efft } \\
(\mathrm{mg} / \mathrm{L})\end{array}$ & $\begin{array}{r}\text { Effy } \\
(\%)\end{array}$ & $\begin{array}{l}\operatorname{Inft} \\
(\mathrm{mg} / \mathrm{L})\end{array}$ & $\begin{array}{l}\text { Efft } \\
(\mathrm{mg} / \mathrm{L})\end{array}$ & $\begin{array}{r}\text { Effy } \\
(\%)\end{array}$ \\
\hline 1 & 160 & 88 & 45 & 356 & 90 & 75 & 47 & 15 & 68 \\
\hline 2 & 183 & 22 & 88 & 329 & 78 & 76 & 39 & 15 & 62 \\
\hline 3 & 150 & 27 & 82 & 522 & 100 & 80 & 50 & 18 & 64 \\
\hline 4 & 160 & 22 & 86 & 380 & 80 & 79 & 48 & 13 & 73 \\
\hline 5 & 147 & 21 & 86 & 313 & 52 & 83 & 41 & 14 & 66 \\
\hline
\end{tabular}

Table 7.2.6 Activated Sludge Performance in Experiment 1 Sludge Age $(\theta c)=$ 6 days

\begin{tabular}{|c|c|c|c|c|c|c|c|c|c|}
\hline \multirow[b]{2}{*}{$\begin{array}{l}\text { Run } \\
\text { No. }\end{array}$} & \multirow[b]{2}{*}{$\begin{array}{c}\text { Inft } \\
(\mathrm{mg} / \mathrm{L})\end{array}$} & \multicolumn{2}{|c|}{$\mathrm{BOD}_{5}$} & \multicolumn{3}{|c|}{ COD } & \multicolumn{3}{|c|}{ TOC } \\
\hline & & $\begin{array}{r}E f f t \\
(m g / L)\end{array}$ & $\begin{array}{l}\text { Effy } \\
(\%)\end{array}$ & $\begin{array}{c}\text { In ft } \\
(\mathrm{mg} / \mathrm{L})\end{array}$ & $\begin{array}{c}E f f t \\
(\mathrm{mg} / \mathrm{L})\end{array}$ & $\begin{array}{c}\text { Effy } \\
(\%)\end{array}$ & $\begin{array}{l}\text { In } \mathrm{ft} \\
(\mathrm{mg} / \mathrm{L})\end{array}$ & $\begin{array}{l}\text { Efft } \\
(\mathrm{mg} / \mathrm{L})\end{array}$ & $\begin{array}{r}\text { Effy } \\
(\%)\end{array}$ \\
\hline 6 & 200 & 25 & 88 & 353 & 81 & 77 & 38 & 16 & 58 \\
\hline 7 & 142 & 26 & 82 & 290 & 78 & 73 & 54 & 25 & 54 \\
\hline 8 & 144 & 20 & 86 & 386 & 70 & 82 & 53 & 21 & 60 \\
\hline 9 & 121 & 15 & 88 & 333 & 60 & 82 & 49 & 13 & 74 \\
\hline 10 & 126 & 10 & 92 & 288 & 67 & 79 & 56 & 25 & 55 \\
\hline
\end{tabular}


Table 7.2.7 Activated Sludge Performance in Experiment 1 Sludge Age $(\theta C)=9$ days

\begin{tabular}{|c|c|c|c|c|c|c|c|c|c|}
\hline \multirow[b]{2}{*}{$\begin{array}{l}\text { Run } \\
\text { No. }\end{array}$} & \multirow[b]{2}{*}{$\begin{array}{c}\text { Inft } \\
(\mathrm{mg} / \mathrm{L})\end{array}$} & \multicolumn{2}{|c|}{$\mathrm{BOD}_{5}$} & \multicolumn{3}{|c|}{ COD } & \multicolumn{3}{|c|}{ TOC } \\
\hline & & $\begin{array}{r}E f f t \\
(\mathrm{mg} / \mathrm{L})\end{array}$ & $\begin{array}{l}\text { Effy } \\
(\%)\end{array}$ & $\begin{array}{c}\text { Inft } \\
(\mathrm{mg} / \mathrm{L})\end{array}$ & $\begin{array}{c}E f f t \\
(\mathrm{mg} / \mathrm{L})\end{array}$ & $\begin{array}{r}\text { Effy } \\
(\%)\end{array}$ & $\begin{array}{l}\text { Inft } \\
(\mathrm{mg} / \mathrm{L})\end{array}$ & $\begin{array}{l}\text { Efft } \\
(\mathrm{mg} / \mathrm{L})\end{array}$ & $\begin{array}{r}\text { Effy } \\
(\%)\end{array}$ \\
\hline 11 & 82 & 11 & 87 & 292 & 58 & 80 & 45 & 12 & 73 \\
\hline 12 & 100 & 20 & 80 & 310 & 71 & 77 & 30 & 11 & 63 \\
\hline 13 & 135 & 16 & 88 & 354 & 79 & 78 & 31 & 11 & 65 \\
\hline 14 & 173 & 16 & 91 & 294 & 60 & 80 & 42 & 10 & 76 \\
\hline 15 & 151 & 15 & 90 & 300 & 67 & 78 & 62 & 15 & 76 \\
\hline
\end{tabular}

Table 7.2.8 Activated Sludge Performance in Experiment 1 Sludge Age $(\theta c)=12$ days

\begin{tabular}{|c|c|c|c|c|c|c|c|c|c|}
\hline \multirow[b]{2}{*}{$\begin{array}{l}\text { Run } \\
\text { No. }\end{array}$} & \multirow[b]{2}{*}{$\underset{\text { (mg/L) }}{\operatorname{Inft}}$} & \multicolumn{2}{|c|}{$\mathrm{BOD}_{5}$} & \multicolumn{3}{|c|}{ COD } & \multicolumn{3}{|c|}{ TOC } \\
\hline & & $\begin{array}{r}E f f t \\
(m g / L)\end{array}$ & $\begin{array}{l}\text { Effy } \\
(\%)\end{array}$ & $\begin{array}{c}\text { Inft } \\
(\mathrm{mg} / \mathrm{L})\end{array}$ & $\begin{array}{c}E f f t \\
(m g / L)\end{array}$ & $\begin{array}{c}\text { Effy } \\
(\%)\end{array}$ & $\begin{array}{l}\text { In ft } \\
\text { (mg/L) }\end{array}$ & $\begin{array}{l}\mathrm{Efft} \\
(\mathrm{mg} / \mathrm{L})\end{array}$ & $\begin{array}{r}\text { Effy } \\
(\%)\end{array}$ \\
\hline 16 & 203 & 19 & 90 & 360 & .50 & 89 & 40 & 9 & 78 \\
\hline 17 & 170 & 15 & 91 & 328 & 54 & 84 & 42 & 10 & 76 \\
\hline 18 & 139 & 15 & 89 & 353 & 48 & 86 & 53 & 12 & 77 \\
\hline 19 & 140 & 16 & 89 & 337 & 50 & 85 & 40 & 9 & 78 \\
\hline 20 & 148 & 10 & 93 & 372 & 48 & 87 & 40 & 10 & 83 \\
\hline
\end{tabular}




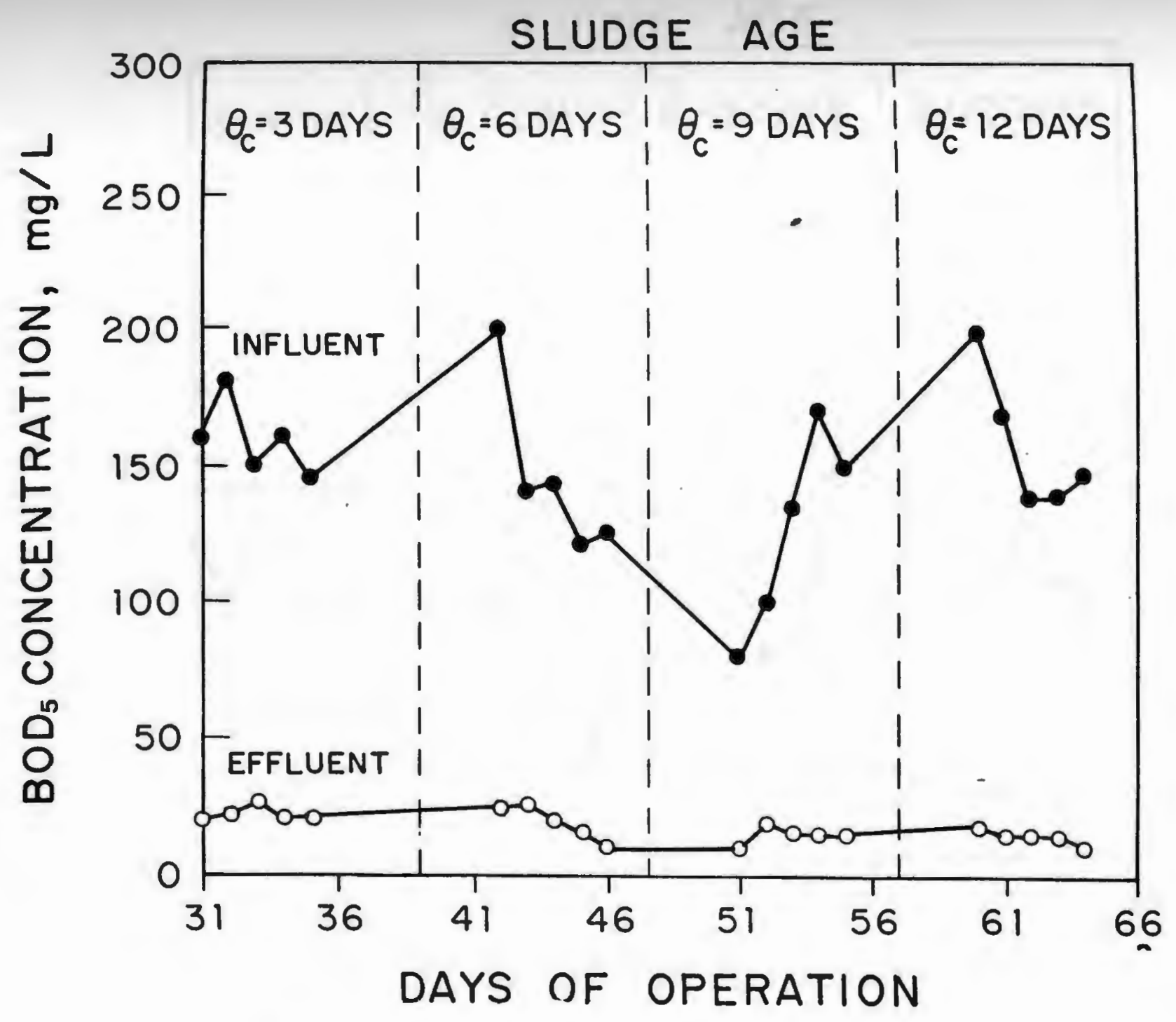

Figure 7.2.1 BOD $_{5}$ Removal by Activated sludge 
SLUDGE AGE

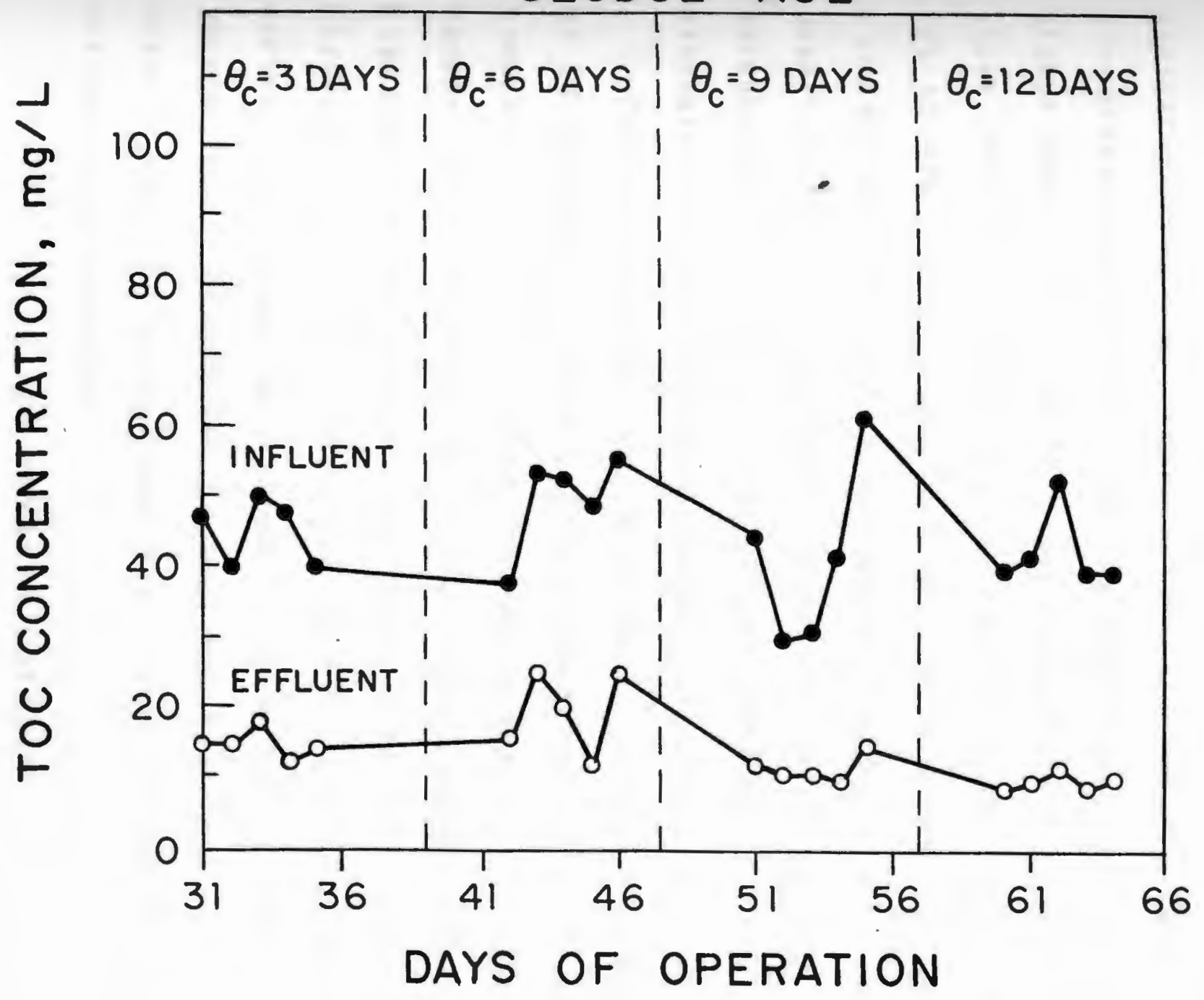

Figure 7.2.2 TOC Removal by Activated Sludge 
Figure 7.2 .3 illustrates the variation in the influent and effluent $\operatorname{COD}$ concentration throughout the activated sludge experiment. Tables 7.2.5-8 present COD concentrations through the AS experiments at various sludge ages $(3,6,9$ and 12 days $)$ respectively. The table shows that the reduction in COD concentration ranged from $70 \%$ to $89 \%$. With this level of reduction, the effluent concentration is still above $50 \mathrm{mg} / \mathrm{L}$ which is unsatisfactiory. The reason would be the changes in the strength of the feed as a result of combined chemical and biological oxidation of the stored wastewater.

Tables 7.2.9-12 show the priority pollutants removal by AS treatment. With a high concentration of organic compounds in the feed flow, the AS treatment was able to remove on the average for 2,4-dimethylphenol, fluorene, naphthalene and pyrene are $90 \%, 77 \%, 68 \%$ and $67 \%$, respectively. The reduction in the priority during various sludge ages were shown in Appendix 3. These data showed that the effluent quality remained almost steady even though the system was not being fed at constant effluent concentration.

Tables 7.2.13-16 present data on the priority pollutants removed by AS treatment at various sludge ages $(3,6,9$, and 12 days), respectively. These pollutants are benzene, chloroform, ethylbenzene, toluene, m-xylene and 


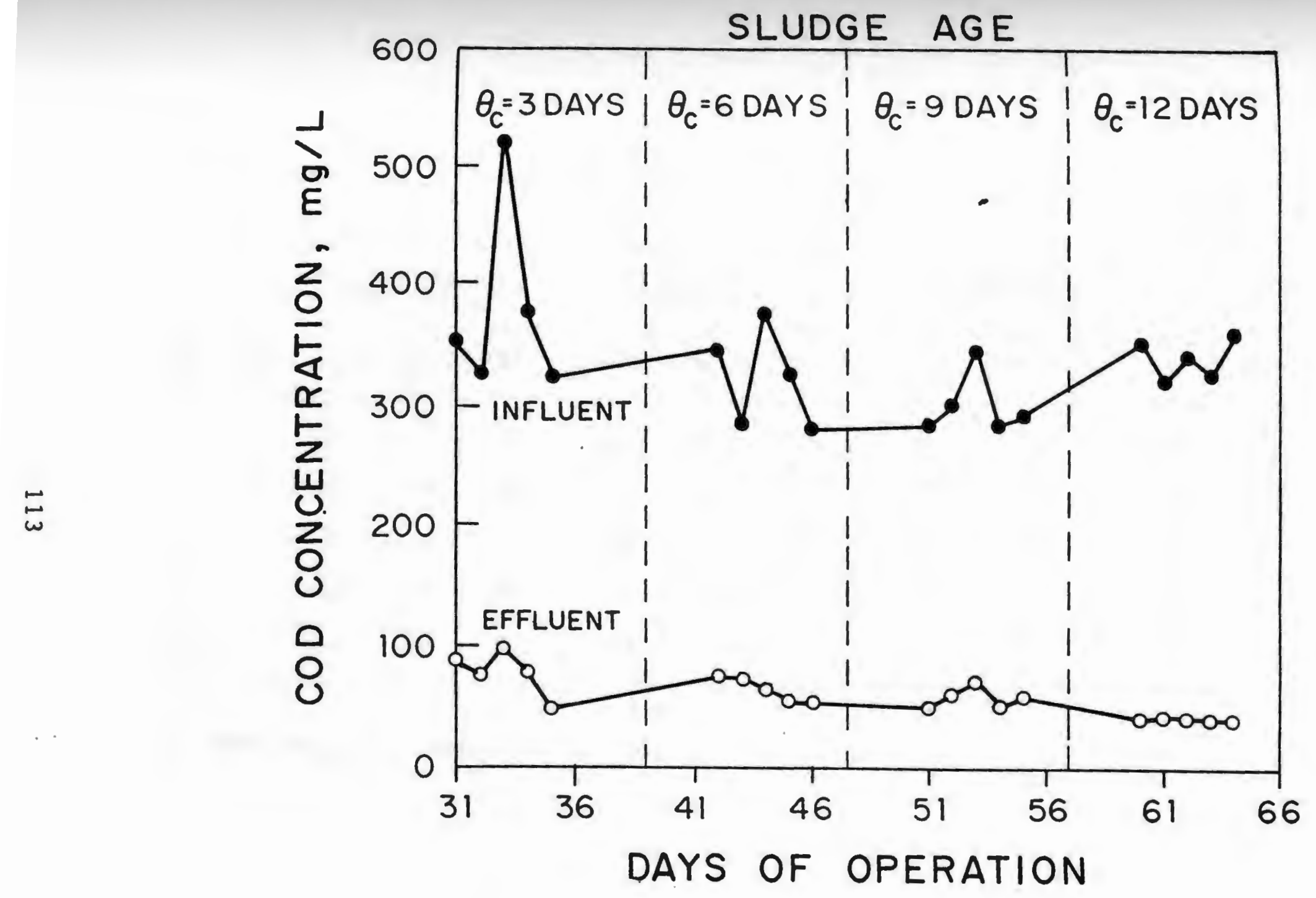

Figure 7.2.3 COD Removal by Activated Sludge 
Table 7.2.9 Priority Pollutants Removal by Activated Sludge, Sludge Age $(\theta c)=3$ days

\begin{tabular}{|c|c|c|c|c|c|c|c|c|c|c|c|c|c|}
\hline \multirow[b]{2}{*}{$\begin{array}{l}\text { Date } \\
1986\end{array}$} & \multicolumn{4}{|c|}{ 2,4-Dimethiphenol } & \multicolumn{2}{|c|}{ Fluorene } & \multirow[b]{2}{*}{$\begin{array}{l}\text { Effy } \\
(\%)\end{array}$} & \multicolumn{3}{|c|}{ Naphthalene } & \multicolumn{2}{|c|}{ Pyrene } & \multirow[b]{2}{*}{$\begin{array}{l}\text { Effy } \\
)^{(\%)}\end{array}$} \\
\hline & $\begin{array}{l}\text { Run } \\
\text { No. }\end{array}$ & $\begin{array}{l}\text { Inft } \\
\text { (ug/L) }\end{array}$ & $\begin{array}{l}\text { Efft } \\
\text { (ug/L) }\end{array}$ & $\begin{array}{l}\text { Effy } \\
(\%)\end{array}$ & $\begin{array}{l}\text { Inft } \\
(\mathrm{ug} / \mathrm{L})\end{array}$ & $\begin{array}{l}\text { Efft } \\
\text { (ug/L) }\end{array}$ & & $\begin{array}{l}\text { Inft } \\
\text { (ug/L) }\end{array}$ & $\begin{array}{l}\text { Efft } \\
(\text { ug/L) }\end{array}$ & $\begin{array}{l}\text { Effy } \\
(\%)\end{array}$ & $\begin{array}{l}\text { In } \mathrm{ft} \\
(\mathrm{ug} / \mathrm{L})\end{array}$ & $\begin{array}{l}\text { Efft } \\
(\text { ug/L) }\end{array}$ & \\
\hline $8 / 31$ & 1 & 570 & 27 & 95 & 139 & 30 & 78 & 33 & 19 & 42 & 27 & ND & $>63$ \\
\hline $9 / 7$ & 2 & 533 & 33 & 94 & 133 & 10 & 92 & 300 & 11 & 96 & 28 & ND & $>64$ \\
\hline $9 / 2$ & 3 & 100 & 33 & 67 & 20 & ND & $>50$ & 40 & 20 & 50 & 20 & ND & $>50$ \\
\hline $9 / 3$ & 4 & 260 & 27 & 90 & 40 & 10 & 75 & 40 & 9 & 78 & 24 & ND & $>58$ \\
\hline $9 / 4$ & 5 & 267 & 20 & 92 & 27 & 11 & 60 & 92 & 18 & 80 & 26 & ND & $>62$ \\
\hline
\end{tabular}

ND = None detectable, detectability $>10 \mathrm{ug} / \mathrm{L}$ 
Table 7.2.10 Priority Pollutants Removal by Activated Sludge, Slúdge Age $(\theta c)=6$ days

\begin{tabular}{|c|c|c|c|c|c|c|c|c|c|c|c|c|c|}
\hline \multirow[b]{2}{*}{$\begin{array}{l}\text { Date } \\
1986\end{array}$} & \multicolumn{4}{|c|}{ 2,4-Dimeth1phenol } & \multicolumn{3}{|c|}{ Fluorene } & \multicolumn{3}{|c|}{ Naph thalene } & \multicolumn{2}{|c|}{ Pyrene } & \multirow[b]{2}{*}{$\begin{array}{r}\text { Effy } \\
)(\%)\end{array}$} \\
\hline & $\begin{array}{l}\text { Run } \\
\text { No. }\end{array}$ & $\begin{array}{l}\text { Inft } \\
(\mathrm{ug} / \mathrm{L})\end{array}$ & $\begin{array}{l}\text { Efft } \\
(\mathrm{ug} / \mathrm{L})\end{array}$ & $\begin{array}{l}\text { Effy } \\
(\%)\end{array}$ & $\begin{array}{l}\text { Inft } \\
\text { (ug/L) }\end{array}$ & $\begin{array}{l}\text { Efft } \\
\text { (ug/L) }\end{array}$ & $\begin{array}{l}\text { Effy } \\
(\%)\end{array}$ & $\begin{array}{l}\text { Inft } \\
(\mathrm{ug} / \mathrm{L})\end{array}$ & $\begin{array}{l}\text { Efft } \\
\text { (ug/L) }\end{array}$ & $\begin{array}{l}\text { Effy } \\
(\%)\end{array}$ & $\begin{array}{l}\text { Inft } \\
(\mathrm{ug} / \mathrm{L})\end{array}$ & $\begin{array}{l}\text { Efft } \\
(\mathrm{ug} / \mathrm{L})\end{array}$ & \\
\hline $9 / 11$ & 6 & 1,887 & 300 & 84 & 67 & 10 & 85 & 300 & 10 & 97 & 30 & 10 & 67 \\
\hline $9 / 12$ & 7 & 333 & 27 & 92 & 27 & ND & $>63$ & 198 & ND & $>97$ & 27 & 11 & 60 \\
\hline $9 / 13$ & 8 & 334 & 73 & 78 & 53 & ND & $>81$ & 1,000 & 33 & 97 & 27 & 12 & 56 \\
\hline $9 / 14$ & 9 & 1,667 & 266 & 84 & 33 & 13 & 67 & 133 & 10 & 92 & 29 & 10 & 66 \\
\hline $9 / 75$ & 10 & 867 & 133 & 85 & 37 & 12 & 68 & 200 & 33 & 84 & 30 & 12 & 60 \\
\hline
\end{tabular}

ND = None detectable, detectability $>10 \mathrm{ug} / \mathrm{L}$ 
Table 7.2.10 Priority Pollutants Removal by Activated Sludge, Slüdge Age $(\theta c)=6$ days

\begin{tabular}{|c|c|c|c|c|c|c|c|c|c|c|c|c|c|}
\hline \multirow[b]{2}{*}{$\begin{array}{l}\text { Date } \\
1986\end{array}$} & \multicolumn{4}{|c|}{ 2,4-Dimethiphenol } & \multicolumn{3}{|c|}{ Fluorene } & \multicolumn{3}{|c|}{ Naphthal ene } & \multicolumn{2}{|c|}{ Pyrene } & \multirow[b]{2}{*}{$\begin{array}{l}\text { Effy } \\
)(\%)\end{array}$} \\
\hline & $\begin{array}{l}\text { Run } \\
\text { No. }\end{array}$ & $\begin{array}{l}\text { Inft } \\
(u g / L)\end{array}$ & $\begin{array}{l}\text { Efft } \\
(u g / L)\end{array}$ & $\begin{array}{l}\text { Effy } \\
(\%)\end{array}$ & $\begin{array}{l}\text { Inft } \\
\text { (ug/L) }\end{array}$ & $\begin{array}{l}\text { Efft } \\
\text { (ug/L) }\end{array}$ & $\begin{array}{l}\text { Effy } \\
(\%)\end{array}$ & $\begin{array}{l}\text { In ft } \\
(\mathrm{ug} / \mathrm{L})\end{array}$ & $\begin{array}{l}\text { Efft } \\
(\text { ug/L) }\end{array}$ & $\begin{array}{l}\text { Effy } \\
(\%)\end{array}$ & $\begin{array}{l}\text { Inft } \\
(\mathrm{ug} / \mathrm{L})\end{array}$ & $\begin{array}{l}\text { Efft } \\
(u g / L)\end{array}$ & \\
\hline $9 / 11$ & 6 & 1,887 & 300 & 84 & 67 & 10 & 85 & 300 & 10 & 97 & 30 & 10 & 67 \\
\hline $9 / 12$ & 7 & 333 & 27 & 92 & 27 & ND & $>63$ & 198 & ND & $>97$ & 27 & 11 & 60 \\
\hline $9 / 13$ & 8 & 334 & 73 & 78 & 53 & ND & $>81$ & 1,000 & 33 & 97 & 27 & 12 & 56 \\
\hline $9 / 14$ & 9 & 1,667 & 266 & 84 & 33 & 13 & 61 & 133 & 10 & 92 & 29 & 10 & 66 \\
\hline $9 / 15$ & 10 & 867 & 133 & 85 & 37 & 12 & 68 & 200 & 33 & 84 & 30 & 12 & 60 \\
\hline
\end{tabular}

ND = None detectable, detectability $>10 \mathrm{ug} / \mathrm{L}$ 
Table 7.2.11 Priority Pollutants Removal by Activated Sludge, Sludge Age $(\theta c)=9$ days

\begin{tabular}{|c|c|c|c|c|c|c|c|c|c|c|c|}
\hline & \multicolumn{3}{|c|}{ 2,4-Dimethlphenol } & \multicolumn{3}{|c|}{ Fluorene } & \multicolumn{3}{|c|}{ Naph thalene } & \multicolumn{2}{|c|}{ Pyrene } \\
\hline $\begin{array}{l}\text { Date } \\
1986\end{array}$ & $\begin{array}{l}\text { Run } \operatorname{Inft} \\
\text { No. }(\mathrm{ug} / \mathrm{L})\end{array}$ & $\begin{array}{l}\text { Efft } \\
\text { (ug/L) }\end{array}$ & $\begin{array}{l}\text { Effy } \\
(\%)\end{array}$ & $\begin{array}{l}\text { Inft } \\
(\mathrm{ug} / \mathrm{L})\end{array}$ & $\begin{array}{l}\text { Efft } \\
\text { (ug/L) }\end{array}$ & $\begin{array}{l}\text { Effy } \\
(\%)\end{array}$ & $\begin{array}{l}\text { Inft } \\
(\mathrm{ug} / \mathrm{L})\end{array}$ & $\begin{array}{l}\text { Efft } \\
\text { (ug/L) }\end{array}$ & $\begin{array}{l}\text { Effy } \\
(\%)\end{array}$ & $\begin{array}{l}\text { In } \mathrm{ft} \\
(\mathrm{ug} / \mathrm{L})\end{array}$ & $\begin{array}{l}\text { Efft Effy } \\
(\mathrm{ug} / \mathrm{L}) \quad(\%)\end{array}$ \\
\hline
\end{tabular}

\begin{tabular}{rrrrrrrrrrrrrr}
\hline $9 / 20$ & 11 & 1,140 & 73 & 94 & 35 & 17 & 51 & 147 & 20 & 86 & 13 & ND & $>30$ \\
$9 / 21$ & 12 & 440 & 20 & 95 & 133 & 24 & 82 & 280 & 21 & 93 & 32 & 13 & 60 \\
$9 / 22$ & 13 & 387 & 27 & 93 & 153 & 17 & 89 & 280 & 23 & 92 & 32 & 13 & 60 \\
$9 / 23$ & 14 & 1,000 & 33 & 97 & 80 & 13 & 84 & 200 & 23 & 89 & 13 & ND & $>20$ \\
$9 / 24$ & 15 & 1,090 & 146 & 87 & 167 & 23 & 86 & 1,200 & 127 & 89 & 12 & ND & $>17$
\end{tabular}

ND = None detectable, detectability $>10 \mathrm{ug} / \mathrm{L}$ 
Table 7.2.12 Priority Pollutants Removal by Activated Sludge, Sludge Age $(\theta c)=12$ days

\begin{tabular}{|c|c|c|c|c|c|c|c|c|c|c|c|c|c|}
\hline \multirow[b]{2}{*}{$\begin{array}{l}\text { Date } \\
1986\end{array}$} & \multicolumn{4}{|c|}{ 2,4-Dimethlphenol } & \multicolumn{3}{|c|}{ Fluorene } & \multicolumn{3}{|c|}{ Naphthalene } & \multicolumn{3}{|c|}{ Pyrene } \\
\hline & $\begin{array}{l}\text { Run } \\
\text { No. }\end{array}$ & $\begin{array}{l}\operatorname{Inft} \\
\text { (ug/L) }\end{array}$ & $\begin{array}{l}\text { Efft } \\
(\mathrm{ug} / \mathrm{L})\end{array}$ & $\begin{array}{l}\text { Effy } \\
(\%)\end{array}$ & $\begin{array}{l}\operatorname{Inft} \\
(\mathrm{ug} / \mathrm{L})\end{array}$ & $\begin{array}{l}\text { Efft } \\
\text { (ug/L) }\end{array}$ & $\begin{array}{l}\text { Effy } \\
(\%)\end{array}$ & $\begin{array}{l}\text { In } \mathrm{ft} \\
(\mathrm{ug} / \mathrm{L})\end{array}$ & $\begin{array}{l}\text { Efft } \\
\text { (ug/L) }\end{array}$ & $\begin{array}{l}\text { Effy } \\
(\%)\end{array}$ & $\begin{array}{l}\text { In } \mathrm{ft} \\
\text { (ug/L) }\end{array}$ & $\begin{array}{l}\text { Efft } \\
(\text { ug/L) }\end{array}$ & $\begin{array}{r}\text { Effy } \\
(\%)\end{array}$ \\
\hline $9 / 29$ & 16 & 547 & 25 & 95 & 174 & 40 & 77 & 933 & 33 & 96 & 41 & 14 & 66 \\
\hline $9 / 30$ & 17 & 404 & 27 & 93 & 207 & 40 & 81 & 1,533 & 27 & 98 & 27 & 12 & 56 \\
\hline $10 / 1$ & 18 & 217 & 17 & 92 & 247 & 41 & 83 & 1,867 & 33 & 98 & 27 & 15 & 44 \\
\hline $10 / 2$ & 19 & 492 & 24 & 94 & 400 & 23 & 94 & 1,867 & 27 & 99 & 110 & 13 & 88 \\
\hline $10 / 3$ & 20 & 613 & 33 & 95 & 320 & 40 & 88 & 2,268 & 43 & 98 & 100 & 14 & 80 \\
\hline
\end{tabular}


Table 7.2.13 Volatile Organics Removal by Activated Sludge Treatment, Sludge Age $(\theta c)=3$ days

\begin{tabular}{|c|c|c|c|c|c|c|c|c|c|c|c|c|c|c|c|c|c|c|c|c|}
\hline \multirow{3}{*}{$\begin{array}{l}\text { Date } \\
1986 \\
8 / 31\end{array}$} & \multirow{3}{*}{$\begin{array}{l}\begin{array}{l}\text { Run } \\
\text { No. }\end{array} \\
1\end{array}$} & \multicolumn{2}{|c|}{ Benzene } & \multirow[b]{2}{*}{$\begin{array}{l}\text { Effy } \\
(\%)\end{array}$} & \multicolumn{3}{|c|}{ Chloroform } & \multicolumn{3}{|c|}{ Ethylbenzene } & \multicolumn{3}{|c|}{ Tolvene } & \multicolumn{3}{|c|}{ m-xylene } & \multicolumn{4}{|c|}{ o-xylene } \\
\hline & & $\begin{array}{l}\text { Inft } \\
\text { (ug/L) }\end{array}$ & $\begin{array}{l}\text { Efft } \\
(\lg / L)\end{array}$ & & $\begin{array}{l}\text { Inft } \\
\text { (ug/L) }\end{array}$ & $\begin{array}{l}\text { Efft } \\
(u g / L)\end{array}$ & $\begin{array}{l}\text { Effy } \\
\text { (\%) }\end{array}$ & $\begin{array}{l}\text { Inft } \\
\text { (ug/L) }\end{array}$ & $\begin{array}{l}\text { Efft } \\
\text { (ug/L) }\end{array}$ & $\begin{array}{l}\text { Effy } \\
(\%)\end{array}$ & $\begin{array}{l}\text { Inft } \\
(\operatorname{Lg} / L)\end{array}$ & $\begin{array}{l}\text { Efft } \\
(\mathrm{ug} / \mathrm{L})\end{array}$ & $\begin{array}{l}\text { Effy } \\
(\%)\end{array}$ & $\begin{array}{l}\text { Inft } \\
\text { (ug/L) }\end{array}$ & $\begin{array}{l}\text { Efft } \\
\text { (ug/L) }\end{array}$ & $\begin{array}{l}\text { Effy } \\
(\%)\end{array}$ & & $\begin{array}{l}\mathrm{fft} \\
\mathrm{g} / \mathrm{L})(\end{array}$ & $\begin{array}{l}\text { Efft } \\
\text { (ug/L) }\end{array}$ & $\begin{array}{r}\text { Effy } \\
(\%)\end{array}$ \\
\hline & & 1,200 & ND & $>99$ & 900 & 30 & 97 & 125 & ND & $>92$ & 200 & ND & $>95$ & 530 & N & D & $>98$ & 720 & & D $>99$ \\
\hline $9 / 1$ & 2 & 330 & ND & $>97$ & 460 & 25 & 95 & 10 & ND & ND & 220 & ND & $>98$ & 640 & N & D & $>98$ & 580 & & ND $>98$ \\
\hline $9 / 2$ & 3 & 640 & ND & $>98$ & 730 & 60 & 92 & 80 & ND & $>88$ & 620 & N & $>98$ & 280 & N & D & $>96$ & 370 & & ND $>97$ \\
\hline $9 / 3$ & 4 & 980 & ND & $>99$ & 1,440 & 80 & 94 & 250 & ND & $>96$ & 1,000 & D & $>99$ & 400 & $\mathrm{~N}$ & D & $>98$ & 560 & & N $>98$ \\
\hline $9 / 4$ & 51 & 1,556 & 20 & 100 & 1,691 & 120 & 93 & 460 & ND & $>98$ & 1,767 & 65 & $>96$ & 700 & N & D & $>99$ & 960 & & ND $>99$ \\
\hline
\end{tabular}

$\mathrm{ND}=$ None detectable, detectability $>10 \mathrm{ug} / \mathrm{L}$ 
Table 7.2.14 Volatile Organics Removal by Activated Sludge Treatment, Sludge Age $(\theta c)=6$ days

\begin{tabular}{|c|c|c|c|c|c|c|c|c|c|c|c|c|c|c|c|c|c|c|c|}
\hline \multirow[b]{2}{*}{$\begin{array}{l}\text { Date } \\
1986\end{array}$} & \multicolumn{4}{|c|}{ Berzene } & \multicolumn{3}{|c|}{ Chloroform } & \multicolumn{2}{|c|}{ Ethylbenzene } & \multicolumn{4}{|c|}{ Toluene } & \multicolumn{2}{|c|}{ m-xylene } & & \multicolumn{2}{|c|}{ o-xylene } & \multirow[b]{2}{*}{$\begin{array}{l}\text { Effy } \\
\text { (\%) }\end{array}$} \\
\hline & $\begin{array}{l}\text { Ran } \\
\text { No. }\end{array}$ & $\begin{array}{l}\text { Inft } \\
\text { (ug/L) }\end{array}$ & $\begin{array}{l}\text { Efft } \\
\text { ( } \mathrm{Lg} / \mathrm{L})\end{array}$ & $\begin{array}{l}\text { Effy } \\
\text { (\%) }\end{array}$ & $\begin{array}{l}\text { Inft } \\
\text { (ug/L) }\end{array}$ & $\begin{array}{l}\text { Efft } \\
\text { (ug/L) }\end{array}$ & $\begin{array}{l}\text { Effy } \\
(\%)\end{array}$ & $\begin{array}{l}\text { Inft } \\
\text { ( } \mathrm{ug} / \mathrm{L})\end{array}$ & $\begin{array}{l}\text { Efft } \\
(\mathrm{ug} / \mathrm{L})\end{array}$ & $\begin{array}{l}\text { Effy } \\
(\%)\end{array}$ & $\begin{array}{l}\text { Inft } \\
\text { (ug/L) }\end{array}$ & $\begin{array}{l}\text { Efft } \\
(\mathrm{ug} / \mathrm{L})\end{array}$ & $\begin{array}{l}\text { Effy } \\
(\%)\end{array}$ & $\begin{array}{c}\text { Inft } \\
\text { (ug/L) }\end{array}$ & $\begin{array}{l}\text { Efft } \\
\text { (Lg/L) }\end{array}$ & $\begin{array}{l}\text { Effy } \\
(\%)\end{array}$ & $\begin{array}{c}\text { Inft } \\
(\lg / L)\end{array}$ & $\begin{array}{l}\text { Efft } \\
\text { ( } \mathrm{ug} / \mathrm{L})\end{array}$ & \\
\hline $9 / 11$ & & 1,761 & ND & $>99$ & 1,952 & ND & $>99$ & 210 & ND & $>95$ & 1,256 & ND & $>99$ & 600 & ND & $>98$ & 780 & ND & $>99$ \\
\hline $9 / 12$ & 7 & 120 & ND & $>92$ & 1,800 & ND & $>99$ & 100 & ND & $>90$ & 120 & NO & $>92$ & 300 & ND & $>97$ & 200 & ND & $>95$ \\
\hline $9 / 13$ & 8 & 960 & ND & $>99$ & 1,718 & 40 & 98 & 300 & ND & $>97$ & 910 & ND & $>99$ & 500 & ND & $>98$ & 610 & ND & $>98$ \\
\hline $9 / 14$ & 9 & 840 & ND & $>99$ & 1,624 & 180 & 89 & 300 & N & 297 & 870 & No & $>99$ & 500 & ND & $>98$ & 630 & ND & $>98$ \\
\hline $9 / 15$ & 101 & 1,130 & ND & $>99$ & 1,780 & 70 & 96 & 410 & DD & 298 & 1,240 & ND & $>99$ & 900 & ND & $>99$ & 1322 & ND & $>99$ \\
\hline
\end{tabular}

$\mathrm{ND}=$ None detectable, detectability $>10 \mathrm{ug} / \mathrm{L}$ 
Table 7.2.15 Volatile Organics Removal by Activated Sludge Treatment, Sludge Age $\left(\theta_{c}\right)=9$ days

\begin{tabular}{|c|c|c|c|c|c|c|c|c|c|c|c|c|c|c|c|c|c|c|c|}
\hline \multirow[b]{2}{*}{$\begin{array}{l}\text { Date } \\
1986\end{array}$} & \multirow[b]{2}{*}{$\begin{array}{l}\text { Run } \\
\text { No. }\end{array}$} & \multicolumn{3}{|c|}{ Benzene } & \multicolumn{3}{|c|}{ Chlorofom } & \multicolumn{2}{|c|}{ Ethylberzene } & \multirow[b]{2}{*}{$\begin{array}{l}\text { Effy } \\
(\%)\end{array}$} & \multicolumn{2}{|c|}{ Toluene } & \multirow[b]{2}{*}{$\begin{array}{l}\text { Effy } \\
(\%)\end{array}$} & \multicolumn{2}{|c|}{ m-xylene } & \multirow[b]{2}{*}{$\begin{array}{l}\text { Effy } \\
(\%)\end{array}$} & \multicolumn{2}{|c|}{ o-xylene } & \multirow[b]{2}{*}{$\begin{array}{c}\text { Effy. } \\
(\%)\end{array}$} \\
\hline & & $\begin{array}{l}\text { Inft } \\
(\mathrm{ug} / \mathrm{L})\end{array}$ & $\begin{array}{l}\text { Efft } \\
(\mathrm{ug} / \mathrm{L})\end{array}$ & $\begin{array}{l}\text { Effy } \\
(\%)\end{array}$ & $\begin{array}{l}\text { Inft } \\
(\lg / L)\end{array}$ & $\begin{array}{l}\text { Efft } \\
(\mathrm{ug} / \mathrm{L})\end{array}$ & $\begin{array}{l}\text { Effy } \\
(\%)\end{array}$ & $\begin{array}{l}\text { Inft } \\
\text { (ug/L) }\end{array}$ & $\begin{array}{l}\text { Efft } \\
(u g / L)\end{array}$ & & $\begin{array}{l}\text { Inft } \\
(\mathrm{Lg} / \mathrm{L})\end{array}$ & $\begin{array}{l}\text { Efft E } \\
(\mathrm{Lg} / \mathrm{L})\end{array}$ & & $\begin{array}{l}\text { Inft } \\
(u g / L)\end{array}$ & $\begin{array}{l}\text { Efft } \\
(u g / L)\end{array}$ & & $\begin{array}{c}\text { Inft } \\
(\mathrm{ug} / \mathrm{L})\end{array}$ & $\begin{array}{l}\text { Efft } \\
(\mathrm{ug} / \mathrm{L})\end{array}$ & \\
\hline $9 / 20$ & 11 & 620 & ND & $>98$ & 1,785 & 158 & 91 & 60 & ND & $>83$ & 460 & ND & $>98$ & 310 & M & $>97$ & 460 & ND & $>98$ \\
\hline $9 / 21$ & 12 & 890 & ND & $>99$ & 1,212 & 10 & 99 & 220 & $\mathrm{ND}$ & 295 & 640 & ND & $>98$ & 360 & N & $>97$ & 460 & $\mathbf{N}$ & $>98$ \\
\hline $9 / 22$ & 13 & 210 & ND & $>95$ & 1,744 & 80 & 95 & 60 & ND & $>83$ & 120 & $\mathbf{N D}$ & $>92$ & 100 & ND & $>90$ & 10 & $N$ & ND \\
\hline $9 / 23$ & 14 & 247 & ND & $>96$ & 2,072 & 66 & 97 & 900 & $\mathbf{N}$ & $>99$ & 233 & $\mathbf{N}$ & $>96$ & 1,097 & No & $>99$ & 1,475 & N & $>99$ \\
\hline $9 / 24$ & 15 & 709 & ND & $>99$ & 1,877 & ND & $>99$ & 640 & ND & $>98$ & 616 & ND & $>98$ & 760 & ND & $>99$ & 980 & ND & $>99$ \\
\hline
\end{tabular}

$\mathrm{ND}=$ None detectable, detectability $>10 \mathrm{ug} / \mathrm{L}$ 
Table 7.2.16 Volatile Organics Removal by Activated Sludge Treatment, Sludge Age $\left(\theta_{C}\right)=12$ days

\begin{tabular}{|c|c|c|c|c|c|c|c|c|c|c|c|c|c|c|c|c|c|c|c|}
\hline \multirow[b]{2}{*}{$\begin{array}{l}\text { Date } \\
1986\end{array}$} & \multirow[b]{2}{*}{$\begin{array}{l}\text { Run } \\
\text { No. }\end{array}$} & \multicolumn{3}{|c|}{ Benzene } & \multicolumn{3}{|c|}{ Chloroform } & \multicolumn{2}{|c|}{ Ethylberzene } & \multicolumn{4}{|c|}{ Toluene } & \multicolumn{2}{|c|}{ m-xylene } & \multirow[b]{2}{*}{$\begin{array}{l}\text { Effy } \\
(\%)\end{array}$} & \multicolumn{2}{|c|}{ o-xylene } & \multirow[b]{2}{*}{$\begin{array}{r}\text { Effy } \\
(\%)\end{array}$} \\
\hline & & $\begin{array}{l}\text { Inft } \\
\text { (ug/L) }\end{array}$ & $\begin{array}{l}\text { Efft } \\
(\mathrm{gg} / \mathrm{L})\end{array}$ & $\begin{array}{l}\text { Effy } \\
(\%)\end{array}$ & $\begin{array}{l}\text { Inft } \\
(u g / L)\end{array}$ & $\begin{array}{l}\text { Efft } \\
(\mathrm{g} / \mathrm{L})\end{array}$ & $\begin{array}{l}\text { Effy } \\
(\%)\end{array}$ & $\begin{array}{l}\text { Inft } \\
(\mathrm{Lg} / \mathrm{L})\end{array}$ & $\begin{array}{l}\text { Efft } \\
(\lg / L)\end{array}$ & $\begin{array}{l}\text { Effy } \\
(\%)\end{array}$ & $\begin{array}{l}\text { Inft } \\
(\mathrm{g} / \mathrm{L})\end{array}$ & $\begin{array}{l}\text { Efft } \\
(u g / L)\end{array}$ & $\begin{array}{l}\text { Effy } \\
(\%)\end{array}$ & $\begin{array}{l}\text { Inft } \\
(\mathrm{ug} / \mathrm{L})\end{array}$ & $\begin{array}{l}\text { Efft } \\
(\mathrm{Lg} / \mathrm{L})\end{array}$ & & $\begin{array}{l}\text { Inft } \\
(\mathrm{Lg} / \mathrm{L})\end{array}$ & $\begin{array}{l}\text { Efft } \\
(\mathrm{Lg} / \mathrm{L})\end{array}$ & \\
\hline $9 / 29$ & 16 & 2,219 & ND & $>99$ & 1,904 & 90 & 95 & 408 & ND & $>98$ & 1,550 & $\mathbf{N}$ & $>99$ & 750 & ND & $>99$ & 930 & ND & $>99$ \\
\hline $9 / 30$ & 17 & 1,976 & ND & $>99$ & $2,054 \quad 3$ & 300 & 85 & 500 & ND & $>98$ & 1,450 & N & $>99$ & 920 & ND & $>99$ & 1,080 & $\mathbf{N}$ & $>99$ \\
\hline $10 / 1$ & 18 & 1,620 & ND & $>99$ & 2,043 & $\infty$ & 96 & 680 & ND & $>99$ & 1,340 & ND & $>99$ & 1,337 & ND & $>99$ & 1,520 & N & $>99$ \\
\hline $10 / 2$ & 19 & 970 & ND & $>99$ & 1,834 & 10 & 99 & 820 & ND & $>99$ & 480 & $\mathbf{N}$ & $>98$ & 750 & ND & $>99$ & 1,040 & ND & $>99$ \\
\hline $10 / 3$ & 20 & 490 & ND & $>98$ & 1,637 & 40 & 98 & 220 & ND & $>95$ & 400 & ND & $>98$ & 340 & N & $>97$ & 440 & NO & $>98$ \\
\hline
\end{tabular}

$N D=$ None detectable, detectability $>10 \mathrm{ug} / \mathrm{L}$ 
o-xylene. These compounds found to be air stripped from the reactor by the air flow (Section 7.5). There were no increases in the percentage removals of the volatile due to the AS. 


\subsection{Experiment 2: Activated Sludge with Powdered Activated Carbon}

To enhance the AS process, PAC was added to the reactor tank in various concentrations over a period of 5 weeks. The PAC concentrations that were maintained in the AS reactor were 10,50 , and $120 \mathrm{mg} / \mathrm{L}$.

The additions of PAC into the reactor resulted in changes in the MLVSS concentration from those measured in the AS process without PAC (experiment 1). The MLVSS results are shown in Tables 7.3.1-12. All additions of PAC resulted in increases in the MLVSS from those measured for the AS without PAC. At a ${ }^{\theta_{C}}$ of 3 days, and PAC concentrations of $10 \mathrm{mg} / \mathrm{L}, 50 \mathrm{mg} / \mathrm{L}$, and $120 \mathrm{mg} / \mathrm{L}$ there was an initial increase in the MLVSS concentration up to a PAC concentration of $50 \mathrm{mg} / \mathrm{L}$ and a slight decrease at 120 $\mathrm{mg} / \mathrm{L}$. For all of the other $\theta_{c}$ values $(6,9$, and 12 days) and all PAC concentrations, the MLVSS at first increased over the AS values and then showed a decrease as the PAC concentrations increased.

The concentrations of selected nutrients (nitrogen and phosphorus) in the influent and effluent were measured three times per week and these values are presented in Tables 7.3.1-12. The influent concentrations of the nutrients were high enough to satisfy the biomass requirements as reported in reference (75).

oil and grease concentrations in the influent and 
Table 7.3.1 Activated Sludge and PAC Perfomances in Experiment 2 when $Q=3$ days and PAC $=10 \mathrm{mg} / \mathrm{L}$, All Concentrations are in $\mathrm{mg} / \mathrm{L}$.

\begin{tabular}{|c|c|c|c|c|c|c|c|c|c|c|c|c|c|c|c|c|c|}
\hline \multirow{2}{*}{\multicolumn{2}{|c|}{ Date Run }} & \multicolumn{4}{|c|}{ Suspended Sol ids } & \multirow{3}{*}{$\begin{array}{l}\mathrm{NH}_{3} \\
\text { Inft }\end{array}$} & \multirow[b]{3}{*}{ Efft } & \multirow{3}{*}{$\begin{array}{l}\mathrm{NO}_{2} \\
\text { Inft }\end{array}$} & \multirow[b]{3}{*}{ Efft } & \multicolumn{2}{|c|}{$\mathrm{NO}_{3}$} & \multicolumn{2}{|c|}{$\begin{array}{c}\text { Total } \\
\text { Phosphate }\end{array}$} & \multicolumn{2}{|c|}{$\begin{array}{c}\text { Ortho- } \\
\text { Phosphate }\end{array}$} & \multicolumn{2}{|c|}{$\begin{array}{c}0 i 1 \\
\text { and Grease } \\
\end{array}$} \\
\hline & & Peact & & Efflue & & & & & & & & & & & & & \\
\hline 1986 & No. & MVSS & MSS & VSS & TSS & & & & & Inft & Efft & Inft & Efft & Inft & Efft & Inft & Efft \\
\hline $10 / 16$ & 21 & 1,500 & 2,100 & 11 & 85 & 54 & 43 & 0.06 & 0.01 & 1.52 & 0.28 & 0.25 & 0.06 & 0.14 & 0.04 & 29 & 9 \\
\hline $10 / 17$ & 22 & 1,600 & 2,700 & 20 & 90 & 30 & 24 & 0.04 & 0.03 & 0.78 & 0.20 & 0.42 & 0.18 & 0.22 & 0.18 & 29 & 10 \\
\hline $10 / 18$ & 23 & 1,740 & 2,032 & 11 & 100 & 51 & 41 & 0.02 & 0.01 & 1.04 & 1.02 & 0.42 & 0.06 & 0.16 & 0.14 & 29 & 10 \\
\hline
\end{tabular}


Table 7.3.2 Activated Sludge and PAC Perfonances in Experiment 2 when $q_{c}=6$ days and PAC $=10 \mathrm{mg} / \mathrm{L}$, All Concentrations are in $\mathrm{mg} / \mathrm{L}$.

\begin{tabular}{|c|c|c|c|c|c|c|c|c|c|c|c|c|c|c|c|c|c|}
\hline \multirow{2}{*}{\multicolumn{2}{|c|}{ Date Run }} & \multicolumn{4}{|c|}{ Suspended Sol ids } & \multirow{3}{*}{$\begin{array}{l}\mathrm{NH}_{3} \\
\text { Inft }\end{array}$} & \multirow[b]{3}{*}{ Efft } & \multirow{3}{*}{$\begin{array}{l}\mathrm{NO}_{2} \\
\text { Inft }\end{array}$} & \multirow[b]{3}{*}{ Efft } & \multicolumn{2}{|c|}{$\mathrm{NO}_{3}$} & \multicolumn{2}{|c|}{$\begin{array}{c}\text { Total } \\
\text { Phosphate }\end{array}$} & \multicolumn{2}{|c|}{$\begin{array}{c}\text { Ortho- } \\
\text { Phosphate }\end{array}$} & \multicolumn{2}{|c|}{$\begin{array}{c}\text { Oil } \\
\text { and Grease }\end{array}$} \\
\hline & & Reacto & & :fflue & & & & & & & & & & & & & \\
\hline 1986 & No. & MVVSS & MSS & vSS & TSS & & & & & Inft & Efft & Inft & Efft & Inft & Efft & Inft & Efft \\
\hline $10 / 20$ & 24 & 2,220 & 3,000 & 12 & 86 & 37 & 30 & 0.08 & 0.01 & 0.48 & 0.06 & 0.14 & 0.07 & 0.12 & 0.06 & 62 & 40 \\
\hline $10 / 21$ & 25 & 2,920 & 3,374 & 15 & 30 & 51 & 44 & 0.10 & 0.03 & 0.07 & 0.01 & 0.30 & 0.01 & 0.28 & 0.09 & 115 & 14 \\
\hline $10 / 22$ & 26 & 2,880 & 3,696 & 35 & 64 & 60 & 30 & 0.07 & 0.04 & 0.36 & 0.12 & 1.0 & 0.03 & 0.31 & 0.12 & 86 & 4 \\
\hline
\end{tabular}


Table 7.3.3 Activated Sludge and PAC Performances in Experiment 2 when $\theta_{c}=9$ days and PAC $=10 \mathrm{mg} / \mathrm{L}$, All concentrations are in $\mathrm{mg} / \mathrm{L}$.

\begin{tabular}{|c|c|c|c|c|c|c|c|c|c|c|c|c|c|c|c|c|c|}
\hline \multirow{2}{*}{\multicolumn{2}{|c|}{ Date Run }} & \multicolumn{4}{|c|}{ Suspended Sol ids } & \multirow[t]{2}{*}{$\underline{\mathrm{NH}_{3}}$} & \multirow[b]{3}{*}{ Efft } & \multicolumn{2}{|c|}{$\mathrm{NO}_{2}$} & \multicolumn{2}{|c|}{$\mathrm{NO}_{3}$} & \multicolumn{2}{|c|}{$\begin{array}{c}\text { Total } \\
\text { Phosphate }\end{array}$} & \multicolumn{2}{|c|}{$\begin{array}{c}\text { Ortho- } \\
\text { Phosphate }\end{array}$} & \multicolumn{2}{|c|}{$\begin{array}{c}\text { Oil } \\
\text { and Grease }\end{array}$} \\
\hline & & React & tor & Efflue & & & & & & & & & & & & & \\
\hline 1986 & No. & MVSS & MSS & vSS & TSS & Inft & & Inft & Efft & Inft & Efft & Inft & Efft & Inft & Efft & Inft & Efft \\
\hline $10 / 26$ & 27 & 3,060 & 3,200 & 11 & 85 & 70 & 50 & 0.11 & 0.03 & 1.94 & 1.90 & 1.0 & 0.02 & 0.24 & 0.08 & 47 & 19 \\
\hline $10 / 27$ & 28 & 3,750 & 3,780 & 5 & 105 & 64 & 50 & 0.16 & 0.02 & 2.0 & 1.20 & 0.60 & 0.16 & 0.29 & 0.19 & 43 & 9 \\
\hline $10 / 28$ & 29 & 3,020 & 3,270 & 15 & 85 & 33 & 23 & 0.13 & 0.02 & 2.17 & 2.04 & 0.28 & 0.14 & 0.14 & 0.10 & 55 & 28 \\
\hline
\end{tabular}


Table 7.3.4 Activated Sludge and PAC performances in Experiment 2 when $\varepsilon_{c}=12$ days and $P A C=10 \mathrm{mg} / \mathrm{L}$, All Concentrations are in $\mathrm{mg} / \mathrm{L}$.

\begin{tabular}{|c|c|c|c|c|c|c|c|c|c|c|c|c|c|c|c|c|c|}
\hline \multirow{2}{*}{\multicolumn{2}{|c|}{ Date Pun }} & \multicolumn{4}{|c|}{ Suspended Sol ids } & \multirow[t]{2}{*}{$\mathrm{NH}_{3}$} & \multirow[b]{3}{*}{ Efft } & \multirow{3}{*}{$\begin{array}{c}\mathrm{NO}_{2} \\
\text { Inft }\end{array}$} & \multirow[b]{3}{*}{ Efft } & \multicolumn{2}{|c|}{$\mathrm{NO}_{3}$} & \multicolumn{2}{|c|}{$\begin{array}{c}\text { Total } \\
\text { Phosphate }\end{array}$} & \multicolumn{2}{|c|}{$\begin{array}{c}\text { Ortho- } \\
\text { Phosphate }\end{array}$} & \multicolumn{2}{|c|}{$\begin{array}{c}\text { Oil } \\
\text { and Grease }\end{array}$} \\
\hline & & React & & fffluen & & & & & & & & & & & & & \\
\hline 1986 & No. & MLVSS & MSS & vSS & TSS & Inft & & & & Inft & Efft & Inft & Efft & Inft & Efft & Inft & Efft \\
\hline $11 / 1$ & 30 & 3,022 & 3,540 & 91 & 210 & 22 & 16 & 0.02 & 0.01 & 2.92 & 0.61 & 1.40 & 0.16 & 0.14 & 0.10 & 55 & 28 \\
\hline $11 / 2$ & 31 & 2,922 & 3,620 & 35 & 44 & 17 & 13 & 0.05 & 0.01 & 2.0 & 0.40 & 0.38 & 0.07 & 0.24 & 0.22 & 102 & 99 \\
\hline $11 / 3$ & 32 & 2,400 & 3,326 & 5 & 125 & 21 & 17 & 0.04 & 0.02 & 0.73 & 0.52 & 0.34 & 0.28 & 0.20 & 0.18 & 35 & 11 \\
\hline
\end{tabular}


Table 7.3.5 Activated Sludge and PAC Performances in Experiment 2 when $\ell_{C}=3$ days and $P A C=50 \mathrm{mg} / \mathrm{L}$, All Concentrations are in $\mathrm{mg} / \mathrm{L}$.

\begin{tabular}{|c|c|c|c|c|c|c|c|c|c|c|c|c|c|c|c|c|c|}
\hline \multirow{3}{*}{$\begin{array}{l}\text { Date } \\
1986\end{array}$} & \multirow[b]{2}{*}{ an } & \multicolumn{4}{|c|}{ suspended solids } & \multirow{3}{*}{$\begin{array}{l}\mathrm{NH}_{3} \\
\text { Inft }\end{array}$} & \multirow[b]{3}{*}{ Efft } & \multirow{3}{*}{$\begin{array}{r}\mathrm{NO}_{2} \\
\text { Inft }\end{array}$} & \multirow[b]{3}{*}{ Efft } & \multicolumn{2}{|c|}{$\mathrm{NO}_{3}$} & \multicolumn{2}{|c|}{$\begin{array}{c}\text { Total } \\
\text { Phosphate }\end{array}$} & \multicolumn{2}{|c|}{$\begin{array}{c}\text { Ortho- } \\
\text { Phosphate }\end{array}$} & \multicolumn{2}{|c|}{$\begin{array}{c}0 i 1 \\
\text { and Grease } \\
\end{array}$} \\
\hline & & Reacto & & fflue & & & & & & & & & & & & & \\
\hline & No. & MLVSS & MLSS & vSS & TSS & & & & & Inft & Efft & Inft & Efft & Inft & Efft & Inft & Efft \\
\hline $11 / 5$ & 33 & 2,880 & 2,920 & 20 & 85 & 26 & 22 & 0.72 & 0.52 & 4.16 & 2.56 & 1.78 & 0.40 & 0.09 & 0.05 & 86 & 37 \\
\hline $11 / 6$ & 34 & 2,520 & 2,660 & 47 & 150 & 28 & 20 & 0.18 & 0.12 & 2.24 & 1.04 & 1.26 & 0.12 & 0.20 & 0.09 & 43 & 32 \\
\hline $11 / 7$ & 35 & 2,334 & 2,800 & 45 & 185 & 24 & 19 & 1.0 & 0.11 & 1.68 & 1.28 & 0.22 & 0.02 & 0.18 & 0.10 & 140 & 44 \\
\hline
\end{tabular}


Table 7.3.6 Activated Sludge and PAC Performance in Experiment 2 when $q_{t}=6$ days and PAC $=50 \mathrm{mg} / \mathrm{L}$, All Concentrations are in $\mathrm{mg} / \mathrm{L}$.

\begin{tabular}{|c|c|c|c|c|c|c|c|c|c|c|c|c|c|c|c|c|c|}
\hline \multirow[b]{2}{*}{ Date Rur } & & \multicolumn{4}{|c|}{ Suspended Sol ids } & \multirow[t]{2}{*}{$\mathrm{NH}_{3}$} & \multirow[b]{3}{*}{ Efft } & \multirow{3}{*}{$\begin{array}{l}\mathrm{NO}_{2} \\
\text { Inft }\end{array}$} & \multirow[b]{3}{*}{ Efft } & \multicolumn{2}{|c|}{$\mathrm{NO}_{3}$} & \multicolumn{2}{|c|}{$\begin{array}{c}\text { Total } \\
\text { Phosphate }\end{array}$} & \multicolumn{2}{|c|}{$\begin{array}{c}\text { ortho- } \\
\text { Phosphate }\end{array}$} & \multicolumn{2}{|c|}{$\begin{array}{c}\text { 0il } \\
\text { and Grease }\end{array}$} \\
\hline & & React & & Efflue & & & & & & & & & & & & & \\
\hline 1986 & No. & Mvss & MSS & VSS & TSS & Inft & & & & Inft & Efft & Inft & Efft & Inft & Efft & Inft & Efft \\
\hline $11 / 10$ & 362 & 2,440 & 2,920 & 5 & 25 & 26 & 22 & 1.0 & 0.24 & 1.92 & 0.16 & 1.20 & 0.10 & 0.20 & 0.16 & 61 & 25 \\
\hline 11/11 & 372 & 2,140 & 3,168 & 20 & 21 & 29 & 22 & 0.40 & 0.34 & 1.60 & 0.80 & 1.25 & 0.17 & 0.30 & 0.23 & 91 & 49 \\
\hline $11 / 12$ & 38 & 2,240 & 3,380 & 10 & 22 & 26 & 24 & 0.60 & 0.44 & 1.92 & 1.60 & 1.60 & 0.12 & 0.24 & 0.10 & 21 & 16 \\
\hline
\end{tabular}


Table 7.3.7 Activated Sludge and PAC Perfomances in Experiment 2 when $\theta_{c}=9$ days and PAC $=50 \mathrm{mg} / \mathrm{L}$, All concentrations are in $\mathrm{mg} / \mathrm{L}$.

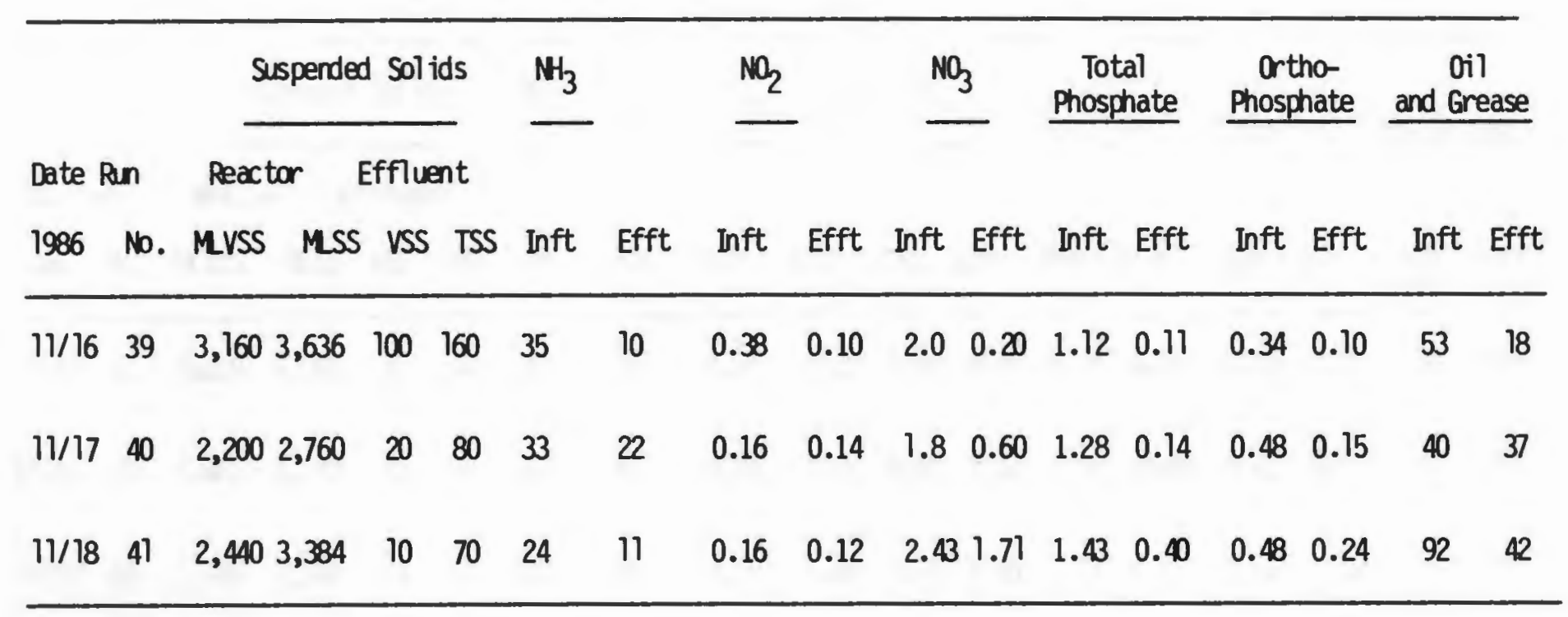


Table 7.3.8 Activated Sludge and PAC Perfomance in Experiment 2 when $\theta_{t}=12$ days and PAC $=50 \mathrm{mg} / \mathrm{L}$, All concentrations are in $\mathrm{mg} / \mathrm{L}$.

\begin{tabular}{|c|c|c|c|c|c|c|c|c|c|c|c|c|c|c|c|c|c|}
\hline \multirow{2}{*}{\multicolumn{2}{|c|}{ Date Ran }} & \multicolumn{4}{|c|}{ Suspended Sol ids } & \multirow{3}{*}{$\begin{array}{l}\mathrm{NH}_{3} \\
\text { Inft }\end{array}$} & \multirow[b]{3}{*}{ Efft } & \multirow{3}{*}{$\begin{array}{l}\mathrm{NO}_{2} \\
\text { Inft }\end{array}$} & \multirow[b]{3}{*}{ Efft } & \multicolumn{2}{|c|}{$\mathrm{NO}_{3}$} & \multicolumn{2}{|c|}{$\begin{array}{c}\text { Total } \\
\text { Phosphate }\end{array}$} & \multicolumn{2}{|c|}{$\begin{array}{c}\text { Ortho- } \\
\text { Phosphate }\end{array}$} & \multicolumn{2}{|c|}{$\begin{array}{c}\text { oil } \\
\text { and Grease } \\
\end{array}$} \\
\hline & & React & tor & fflue & & & & & & & & & & & & & \\
\hline 1986 & No. & MLSS & MSS & vSS & TSS & & & & & Inft & Efft & Inft & Efft & Inft & Efft & Inft & Efft \\
\hline $11 / 21$ & 42 & 3,020 & 3,568 & 35 & 40 & 29 & 18 & 2.15 & 1.52 & 2.24 & 2.00 & 1.26 & 0.18 & 0.20 & 0.10 & 92 & 40 \\
\hline $11 / 21$ & 43 & 2,480 & 3,274 & 30 & 36 & 30 & 20 & 3.10 & 1.41 & 2.08 & 1.44 & 1.14 & 0.08 & 0.62 & 0.10 & 45 & 19 \\
\hline $111 / 23$ & 44 & 2,140 & 3,676 & 59 & 60 & 102 & 83 & 2.10 & 1.66 & 2.64 & 2.48 & 1.44 & 0.83 & 0.62 & 0.15 & 14 & 11 \\
\hline
\end{tabular}


Table 7.3.9 Activated Sludge and PAC Performances in Exper ment 2 when $\theta_{C}=3$ days and PAC $=120 \mathrm{mg} / \mathrm{L}$, All Concentrations are in $\mathrm{mg} / \mathrm{L}$.

\begin{tabular}{|c|c|c|c|c|c|c|c|c|c|c|c|c|c|c|c|c|c|}
\hline \multirow{2}{*}{\multicolumn{2}{|c|}{ Date Run }} & \multicolumn{4}{|c|}{ Suspended Sol ids } & \multirow{3}{*}{$\begin{array}{l}\mathrm{NH}_{3} \\
\text { Inft }\end{array}$} & \multirow[b]{3}{*}{ Efft } & \multirow{3}{*}{$\begin{array}{l}\mathrm{NO}_{2} \\
\text { Inft }\end{array}$} & \multirow[b]{3}{*}{ Efft } & \multicolumn{2}{|c|}{$\mathrm{NO}_{3}$} & \multicolumn{2}{|c|}{$\begin{array}{c}\text { Total } \\
\text { Phosphate }\end{array}$} & \multicolumn{2}{|c|}{$\begin{array}{c}\text { Ortho- } \\
\text { Phosphate }\end{array}$} & \multicolumn{2}{|c|}{$\begin{array}{l}\quad 0 i 1 \\
\text { and Grease } \\
\end{array}$} \\
\hline & & React & & fflue & & & & & & & & & & & & & \\
\hline 1986 & No. & MLVSS & MSS & vSS & TSS & & & & & Inft & Efft & Inft & Efft & Inft & Efft & Inft & Efft \\
\hline $11 / 26$ & 45 & 2,080 & $2, \sqrt{54}$ & 24 & 45 & 77 & 70 & 1.28 & 0.18 & 2.62 & 2.06 & 1.32 & 0.20 & 0.77 & 0.08 & 28 & 20 \\
\hline $11 / 27$ & 46 & 2,380 & 2,620 & 3 & 5 & 74 & 62 & 1.04 & 0.11 & 1.68 & 0.36 & 1.42 & 0.40 & 0.96 & 0.16 & 58 & 13 \\
\hline $11 / 28$ & 47 & 2,280 & 3,788 & 5 & 18 & 57 & 39 & 1.84 & 0.08 & 3.76 & 1.40 & 1.35 & 0.34 & 0.85 & 0.15 & 27 & 21 \\
\hline
\end{tabular}



Table 7.3.10 Activated Sludge and PAC Performances in Experiment 2 when $\theta_{\tau}=6$ days and $P A C=120 \mathrm{mg} / \mathrm{L}$,
All Concentrations are in $\mathrm{mg} / \mathrm{L}$.

\begin{tabular}{|c|c|c|c|c|c|c|c|c|c|c|c|c|c|c|c|c|c|}
\hline \multirow{2}{*}{\multicolumn{2}{|c|}{ Date Ran }} & \multicolumn{4}{|c|}{ Suspended Sol ids } & \multirow[t]{2}{*}{$\underline{\mathrm{NH}_{3}}$} & \multirow[b]{3}{*}{ Efft } & \multirow{3}{*}{$\begin{array}{l}\mathrm{NO}_{2} \\
\text { Inft }\end{array}$} & \multirow[b]{3}{*}{ Efft } & \multicolumn{2}{|c|}{$\mathrm{NO}_{3}$} & \multicolumn{2}{|c|}{$\begin{array}{c}\text { Total } \\
\text { Phosphate }\end{array}$} & \multicolumn{2}{|c|}{$\begin{array}{c}\text { Ortho- } \\
\text { Phosphate }\end{array}$} & \multicolumn{2}{|c|}{$\begin{array}{c}\text { Oil } \\
\text { and Grease } \\
\end{array}$} \\
\hline & & Reac & & Efflue & & & & & & & & & & & & & \\
\hline 1986 & No. & MVSS & MLSS & VSS & TSS & Inft & & & & Inft & Efft & Inft & Efft & Inft & Efft & Inft & Efft \\
\hline $12 / 7$ & 48 & 2,280 & 2,700 & 15 & 20 & 54 & 30 & 1.60 & 0.80 & 2.72 & 1.80 & 2.54 & 0.48 & 1.80 & 0.10 & 27 & 21 \\
\hline $12 / 3$ & 49 & 2,100 & 2,400 & 5 & 80 & 31 & 20 & 0.52 & 0.13 & 3.4 & 0.75 & 2.58 & 0.56 & 1.0 & 0.18 & 23 & 8 \\
\hline $12 / 4$ & 50 & 2,200 & 2,450 & 5 & 20 & 31 & 20 & 2.40 & 0.07 & 2.96 & 1.00 & 2.66 & 0.58 & 0.94 & 0.08 & 31 & 14 \\
\hline
\end{tabular}


Table 7.3.11 Activated Sludge and PAC Perfomances in Experiment 2 when $q_{c}=9$ days and $P A C=120 \mathrm{mg} / \mathrm{L}$, All Concentrations are in $\mathrm{mg} / \mathrm{L}$.

\begin{tabular}{|c|c|c|c|c|c|c|c|c|c|c|c|c|c|c|c|c|c|}
\hline \multirow{2}{*}{\multicolumn{2}{|c|}{ Date Run }} & \multicolumn{4}{|c|}{ Suspended Sol ids } & \multirow{3}{*}{$\begin{array}{l}\mathrm{NH}_{3} \\
- \\
\text { Inft }\end{array}$} & \multirow[b]{3}{*}{ Efft } & \multirow{3}{*}{$\begin{array}{l}\mathrm{NO}_{2} \\
\text { Inft }\end{array}$} & \multirow[b]{3}{*}{ Efft } & \multicolumn{2}{|c|}{$\mathrm{NO}_{3}$} & \multicolumn{2}{|c|}{$\begin{array}{c}\text { Total } \\
\text { Phosphate }\end{array}$} & \multicolumn{2}{|c|}{$\begin{array}{c}\text { Ortho- } \\
\text { Phosphate }\end{array}$} & \multicolumn{2}{|c|}{$\begin{array}{c}0 \mathrm{il} \\
\text { and Grease } \\
\end{array}$} \\
\hline & & Peact & & Efflue & & & & & & & & & & & & & \\
\hline 1986 & No. & Muss & MSS & vSS & TSS & & & & & Inft & Efft & Inft & Efft & Inft & Efft & Inft & Efft \\
\hline $12 / 7$ & 51 & 1,800 & 2,350 & 5 & 10 & 34 & 16 & 0.80 & 0.22 & 3.52 & 2.16 & 2.40 & 0.56 & 1.40 & 0.15 & 25 & 17 \\
\hline $12 / 8$ & 52 & 1,894 & 2,400 & 12 & 20 & 25 & 14 & 0.12 & 0.10 & 2.40 & 1.20 & 1.5 & 0.64 & 0.92 & 0.06 & 17 & 12 \\
\hline $12 / 9$ & 53 & 2,200 & 2,648 & 5 & 15 & 24 & 11 & 0.32 & 0.08 & 2.24 & 0.92 & 1.48 & 0.44 & 0.24 & 0.10 & 15 & 10 \\
\hline
\end{tabular}


Table 7.3.12 Activated Sludge and PAC Perfomances in Experiment 2 when $\theta_{c}=12$ days and $P A C=120 \mathrm{mg} / \mathrm{L}$, All concentrations are in $\mathrm{mg} / \mathrm{L}$.

\begin{tabular}{|c|c|c|c|c|c|c|c|c|c|c|c|c|c|c|c|c|c|}
\hline \multirow{2}{*}{\multicolumn{2}{|c|}{ Date Run }} & \multicolumn{4}{|c|}{ Suspended Sol ids } & \multirow[t]{2}{*}{$\underline{\mathrm{NH}_{3}}$} & \multirow[b]{3}{*}{ Efft } & \multirow{3}{*}{$\begin{array}{l}\frac{\mathrm{NO}_{2}}{\text { Inft }} \\
-\end{array}$} & \multirow[b]{3}{*}{ Efft } & \multicolumn{2}{|c|}{$\mathrm{NO}_{3}$} & \multicolumn{2}{|c|}{$\begin{array}{c}\text { Total } \\
\text { Phosphate }\end{array}$} & \multicolumn{2}{|c|}{$\begin{array}{c}\text { Ortho- } \\
\text { Phosphate }\end{array}$} & \multicolumn{2}{|c|}{$\begin{array}{c}0 i 1 \\
\text { and Grease }\end{array}$} \\
\hline & & Peact & & Effluen & & & & & & & & & & & & & \\
\hline 1986 & No. & Muss & MSS & VSS & TSS & Inft & & & & Inft & Efft & Inft & Efft & Inft & Efft & Inft & Efft \\
\hline $12 / 12$ & 54 & 2,090 & 2,400 & 15 & 28 & 21 & 8 & 0.12 & 0.08 & 3.44 & 1.66 & 1.58 & 0.44 & 1.25 & 0.06 & 21 & 15 \\
\hline $12 / 13$ & 55 & 2,100 & 2,500 & 11 & 40 & 24 & 7 & 0.12 & 0.09 & 3.76 & 2.08 & 2.25 & 0.90 & 0.91 & 0.06 & 21 & 10 \\
\hline $12 / 15$ & 56 & 2,694 & 2,950 & 5 & 40 & 26 & 11 & 0.34 & 0.26 & 4.80 & 3.04 & 2.79 & 0.35 & 0.91 & 0.07 & 27 & 26 \\
\hline
\end{tabular}


effluent were also measured 3 times each week and are reported in Tables 7.3.1-12. The influent 0 il and grease concentrations were below the levels found to be toxic $(100 \mathrm{mg} / \mathrm{L})$ by other researchers (75).

$B O D_{5}$ removals were enhanced by $P A C$ additions. The PAC concentration present in the AS reactor did not appear to effect the percentage removals of $B O D_{5}$. A concentration of $10 \mathrm{mg} / \mathrm{L}$ of $P A C$ enhanced $B O D_{5}$ removals within the AS reactors about as well as a PAC concentration of 50 or $120 \mathrm{mg} / \mathrm{L}$. With the exception of a PAC concentration of $10 \mathrm{mg} / \mathrm{L}$ which showed a sight improvement in $\mathrm{BOD}_{5}$ removals as ${ }^{\theta_{C}}$ increased, there was no significant increase in the removal percentages as $\theta_{C}$ was increased to 12 days. This data is presented in Tables 7.3.13-24. The influent and effluent concentrations versus day of operation are plotted in Figures 7.3.1-7.3.3. The effluent percentage removals versus $\theta_{c}$ are plotted in Figure 7.3 .4 .

COD removals were improved, compared to AS, by the additions of all concentrations of PAC. With the exception of $\theta_{c}$ equal to 3 days, the highest percentage removals were at a PAC concentration of $10 \mathrm{mg} / \mathrm{L}$. For all $\theta_{c}$ values, the lowest percentage removals of COD occurred at a PAC concentration of $50 \mathrm{mg} / \mathrm{L}$. As $\theta_{C}$ increased, the percentage removals of COD increased, with the exception of a PAC concentration of $120 \mathrm{mg} / \mathrm{L}$, in which case there 
Table 7.3.13 $\mathrm{BOD}_{5}, \mathrm{COD}$, and TOC Removals in Experiment 2 when $\theta_{C}=3$ days and $P A C=10 \mathrm{mg} / \mathrm{L}$

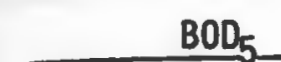

$\mathrm{BOD}_{5}$

$\longrightarrow$

-

Run Inft Efft Effy Inft Efft Effy Inft Efft Effy

No. $\quad(\mathrm{mg} / \mathrm{L})(\mathrm{mg} / \mathrm{L})(\%) \quad(\mathrm{mg} / \mathrm{L})(\mathrm{mg} / \mathrm{L}) \quad(\%) \quad(\mathrm{mg} / \mathrm{L})(\mathrm{mg} / \mathrm{L})(\%)$

$\begin{array}{llllllllll}21 & 213 & 35 & 84 & 510 & 70 & 86 & 168 & 24 & 86 \\ 22 & 214 & 28 & 87 & 480 & 74 & 85 & 160 & 20 & 88 \\ 23 & 242 & 27 & 89 & 504 & 72 & 86 & 182 & 28 & 85\end{array}$

TOC
Table 7.3.14 $\mathrm{BOD}_{5}, \mathrm{COD}$ and TOC Removals in Experiment 2 when $\theta_{C}=6$ days and $P A C=10 \mathrm{mg} / \mathrm{L}$

\begin{tabular}{|c|c|c|c|c|c|c|c|c|c|}
\hline \multirow[b]{2}{*}{$\begin{array}{l}\text { Run } \\
\text { No. }\end{array}$} & \multicolumn{3}{|c|}{$\mathrm{BOD}_{5}$} & \multicolumn{3}{|c|}{$C O D$} & \multicolumn{3}{|c|}{ TOC } \\
\hline & $\begin{array}{l}\text { Inft } \\
(\mathrm{mg} / \mathrm{L})\end{array}$ & $\begin{array}{l}\text { Efft } \\
(\mathrm{mg} / \mathrm{L})\end{array}$ & $\begin{array}{r}\text { Effy } \\
(\%)\end{array}$ & $\begin{array}{l}\text { Inft } \\
(\mathrm{mg} / \mathrm{L})\end{array}$ & $\begin{array}{l}\text { Efft } \\
(\mathrm{mg} / \mathrm{L})\end{array}$ & $\begin{array}{r}\text { Effy } \\
(\%)\end{array}$ & $\begin{array}{l}\text { Inft } \\
(\mathrm{mg} / \mathrm{L})\end{array}$ & $\begin{array}{l}\text { Efft } \\
(\mathrm{mg} / \mathrm{L})\end{array}$ & $\begin{array}{r}\text { Effy } \\
(\%)\end{array}$ \\
\hline 24 & 321 & 26 & 92 & 564 & 31 & 95 & 245 & 19 & 92 \\
\hline 25 & 332 & 30 & 91 & 550 & 32 & 94 & 200 & 13 & 94 \\
\hline 26 & 348 & 28 & 92 & 530 & 27 & 95 & 221 & 25 & 89 \\
\hline
\end{tabular}


Table 7.3.15 $\mathrm{BOD}_{5}, \mathrm{COD}$ and TOC Removals in Experiment 2 when $\theta_{C}=9$ days and $P A C=10 \mathrm{mg} / \mathrm{L}$

$\mathrm{BOO}_{5}$

$\operatorname{COD}$

TOC

Run Inft Efft Effy Inft Efft Effy Inft Efft Effy No. $(\mathrm{mg} / \mathrm{L})(\mathrm{mg} / \mathrm{L})(\%)(\mathrm{mg} / \mathrm{L})(\mathrm{mg} / \mathrm{L})(\%) \quad(\mathrm{mg} / \mathrm{L})(\mathrm{mg} / \mathrm{L})(\%)$

\begin{tabular}{llllllllll}
\hline 27 & 350 & 22 & 94 & 550 & 30 & 95 & 170 & 16 & 91 \\
28 & 340 & 20 & 94 & 548 & 26 & 95 & 180 & 17 & 91 \\
29 & 345 & 24 & 93 & 552 & 20 & 96 & 184 & 18 & 90 \\
\hline
\end{tabular}

Table 7.3.16 $\mathrm{BOD}_{5}, \mathrm{COD}$ and TOC Removals in Experiment 2 when $\theta_{C}=12$ days and $P A C=10 \mathrm{mg} / \mathrm{L}$

\begin{tabular}{|c|c|c|c|c|c|c|c|c|c|}
\hline \multirow[b]{2}{*}{$\begin{array}{l}\text { Run } \\
\text { No. }\end{array}$} & \multicolumn{3}{|c|}{$\mathrm{BOO}_{5}$} & \multicolumn{3}{|c|}{ COD } & \multicolumn{3}{|c|}{ TOC } \\
\hline & $\begin{array}{l}\text { Inft } \\
(\mathrm{mg} / \mathrm{L})\end{array}$ & $\begin{array}{l}\text { Efft } \\
(\mathrm{mg} / \mathrm{L})\end{array}$ & $\begin{array}{r}\text { Effy } \\
(\%)\end{array}$ & $\begin{array}{l}\text { Inft } \\
(\mathrm{mg} / \mathrm{L})\end{array}$ & $\begin{array}{l}\text { Efft } \\
(\mathrm{mg} / \mathrm{L})\end{array}$ & $\begin{array}{r}\text { Effy } \\
(\%)\end{array}$ & $\begin{array}{l}\text { Inft } \\
(\mathrm{mg} / \mathrm{L})\end{array}$ & $\begin{array}{l}\text { Efft } \\
(\mathrm{mg} / \mathrm{L})\end{array}$ & $\begin{array}{r}\text { Effy } \\
(\%)\end{array}$ \\
\hline 30 & 320 & 21 & 93 & 478 & 20 & 96 & 151 & 17 & 89 \\
\hline 31 & 300 & 18 & 94 & 420 & 15 & 96 & 144 & 14 & 90 \\
\hline 32 & 344 & 24 & 93 & 488 & 25 & 95 & 158 & 14 & 91 \\
\hline
\end{tabular}


Table 7.3.17 $\mathrm{BOD}_{5}, \mathrm{COD}$ and TOC Removals in Experiment 2 when $\theta_{C}=3$ days and $P A C=50 \mathrm{mg} / \mathrm{L}$

$\frac{\mathrm{BOD}_{5}}{\mathrm{COD}} \frac{\mathrm{TOC}}{\mathrm{C}}$

Run Inft Efft Effy Inft Efft Effy Inft Efft Effy

No. $(\mathrm{mg} / \mathrm{L})(\mathrm{mg} / \mathrm{L})(\%) \quad(\mathrm{mg} / \mathrm{L})(\mathrm{mg} / \mathrm{L})(\%) \quad(\mathrm{mg} / \mathrm{L})(\mathrm{mg} / \mathrm{L})(\%)$

$\begin{array}{llllllllll}33 & 305 & 29 & 90 & 976 & 210 & 79 & 847 & 36 & 96 \\ 34 & 304 & 29 & 90 & 416 & 100 & 76 & 135 & 28 & 79 \\ 35 & 302 & 22 & 93 & 776 & 200 & 74 & 119 & 29 & 76\end{array}$

Table 7.3.18 $\mathrm{BOD}_{5}, \mathrm{COD}$ and TOC Removals in Experiment 2 when $\theta_{C}^{5}=6$ days and $P A C=50 \mathrm{mg} / \mathrm{L}$

\begin{tabular}{|c|c|c|c|c|c|c|c|c|c|}
\hline \multirow[b]{2}{*}{$\begin{array}{l}\text { Run } \\
\text { No. }\end{array}$} & \multicolumn{3}{|c|}{$\mathrm{BOD}_{5}$} & \multicolumn{3}{|c|}{$C O D$} & \multicolumn{3}{|c|}{ TOC } \\
\hline & $\begin{array}{l}\text { Inft } \\
(\mathrm{mg} / \mathrm{L})\end{array}$ & $\begin{array}{l}\text { Efft } \\
(\mathrm{mg} / \mathrm{L})\end{array}$ & $\begin{array}{r}\text { Effy } \\
(\%)\end{array}$ & $\begin{array}{l}\text { Inft } \\
(\mathrm{mg} / \mathrm{L})\end{array}$ & $\begin{array}{l}\text { Efft } \\
(\mathrm{mg} / \mathrm{L})\end{array}$ & $\begin{array}{r}\text { Effy } \\
(\%)\end{array}$ & $\begin{array}{l}\operatorname{Inft} \\
(\mathrm{mg} / \mathrm{L})\end{array}$ & $\begin{array}{l}\text { Efft } \\
(\mathrm{mg} / \mathrm{L})\end{array}$ & $\begin{array}{r}\text { Effy } \\
(\%)\end{array}$ \\
\hline 36 & 320 & 29 & 87 & 796 & 192 & 76 & 554 & 45 & 83 \\
\hline 37 & 213 & 25 & 88 & 516 & 160 & 69 & 123 & 27 & 83 \\
\hline 38 & 248 & 10 & 96 & 488 & 100 & 80 & 127 & 18 & 86 \\
\hline
\end{tabular}


Table 7.3.19 $\mathrm{BOD}_{5}, \mathrm{COD}$ and TOC Removals in Experiment 2 when $\theta_{C}=9$ days and $P A C=50 \mathrm{mg} / \mathrm{L}$

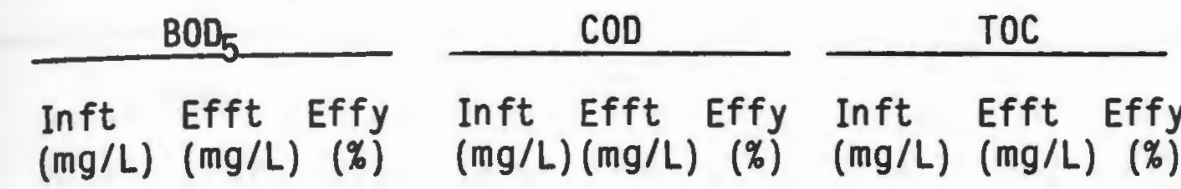

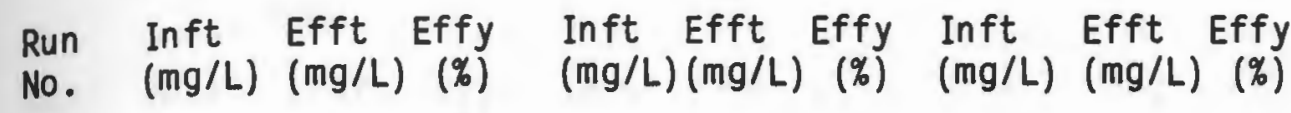

$\begin{array}{llllllllll}39 & 245 & 21 & 91 & 560 & 132 & 76 & 213 & 19 & 91\end{array}$

$\begin{array}{llllllllll}40 & 255 & 22 & 91 & 420 & 68 & 84 & 232 & 21 & 90\end{array}$

$\begin{array}{llllllllll}41 & 257 & 22 & 92 & 776 & 116 & 85 & 232 & 20 & 91\end{array}$

Table 7.3.20 $\mathrm{BOD}_{5}, \mathrm{COD}$ and TOC Removals in Experiment 2 when $\theta_{c}=12$ days and $P A C=50 \mathrm{mg} / \mathrm{L}$

\begin{tabular}{|c|c|c|c|c|c|c|c|c|c|}
\hline \multirow[b]{2}{*}{$\begin{array}{l}\text { Run } \\
\text { No. }\end{array}$} & \multicolumn{3}{|c|}{$\mathrm{BOO}_{5}$} & \multicolumn{3}{|c|}{ COD } & \multicolumn{3}{|c|}{ TOC } \\
\hline & $\begin{array}{l}\operatorname{Inft} \\
(\mathrm{mg} / \mathrm{L})\end{array}$ & $\begin{array}{l}\text { Efft } \\
(\mathrm{mg} / \mathrm{L})\end{array}$ & $\begin{array}{r}\text { Effy } \\
(\%)\end{array}$ & $\begin{array}{l}\text { Inft } \\
(\mathrm{mg} / \mathrm{L})\end{array}$ & $\begin{array}{l}\text { Efft } \\
(\mathrm{mg} / \mathrm{L})\end{array}$ & $\begin{array}{r}\text { Effy } \\
(\%)\end{array}$ & $\begin{array}{l}\text { Inft } \\
(\mathrm{mg} / \mathrm{L})\end{array}$ & $\begin{array}{l}\text { Efft } \\
(\mathrm{mg} / \mathrm{L})\end{array}$ & $\begin{array}{r}\text { Effy } \\
(\%)\end{array}$ \\
\hline 42 & 205 & 21 & 90 & 496 & 128 & 74 & 203 & 16 & 92 \\
\hline 43 & 278 & 20 & 93 & 404 & 56 & 86 & 214 & 15 & 93 \\
\hline 44 & 235 & 19 & 92 & 804 & 120 & 85 & 225 & 18 & 92 \\
\hline
\end{tabular}


Table 7.3.21 $\mathrm{BOD}_{5}, \mathrm{COD}$ and TOC Removals in Experiment 2 when $\theta_{C}=3$ days and $P A C=120 \mathrm{mg} / \mathrm{L}$

Run Inft Efft Effy Inft Efft Effy Inft Efft Effy

No. $(\mathrm{mg} / \mathrm{L})(\mathrm{mg} / \mathrm{L})(\%) \quad(\mathrm{mg} / \mathrm{L})(\mathrm{mg} / \mathrm{L})(\%)(\mathrm{mg} / \mathrm{L})(\mathrm{mg} / \mathrm{L})(\%)$

\begin{tabular}{llllllllll}
\hline 45 & 292 & 26 & 91 & 360 & 30 & 92 & 191 & 13 & 93 \\
46 & 255 & 30 & 88 & 540 & 50 & 91 & 205 & 17 & 92 \\
47 & 300 & 28 & 91 & 624 & 70 & 89 & 260 & 20 & 92
\end{tabular}

Table 7.3.22 $\mathrm{BOD}_{5}, \mathrm{COD}$ and TOC REmovals in Experiment 2 when $\theta_{c}=6$ days and $P A C=120 \mathrm{mg} / \mathrm{L}$

\begin{tabular}{|c|c|c|c|c|c|c|c|c|c|}
\hline \multirow[b]{2}{*}{$\begin{array}{l}\text { Run } \\
\text { No. }\end{array}$} & \multicolumn{3}{|c|}{$\mathrm{BOD}_{5}$} & \multicolumn{3}{|c|}{$\mathrm{COD}$} & \multicolumn{3}{|c|}{ TOC } \\
\hline & $\begin{array}{l}\text { Inft } \\
(\mathrm{mg} / \mathrm{L})\end{array}$ & $\begin{array}{l}\text { Efft } \\
(\mathrm{mg} / \mathrm{L})\end{array}$ & $\begin{array}{r}\text { Effy } \\
(\%)\end{array}$ & $\begin{array}{l}\text { Inft } \\
(\mathrm{mg} / \mathrm{L})\end{array}$ & $\begin{array}{l}\text { Efft } \\
(\mathrm{mg} / \mathrm{L})\end{array}$ & $\begin{array}{r}\text { Effy } \\
(\%)\end{array}$ & $\begin{array}{l}\text { Inft } \\
\text { (mg/L) }\end{array}$ & $\begin{array}{l}\text { Efft } \\
(\mathrm{mg} / \mathrm{L})\end{array}$ & $\begin{array}{l}\text { Effy } \\
(\%)\end{array}$ \\
\hline 48 & 295 & 30 & 90 & 360 & 35 & 90 & 188 & 17 & 91 \\
\hline 49 & 249 & 24 & 90 & 356 & 25 & 93 & 184 & 13 & 93 \\
\hline 50 & 222 & 21 & 91 & 515 & 60 & 88 & 188 & 15 & 92 \\
\hline
\end{tabular}


Table 7.3.23 $\mathrm{BOD}_{5}, \mathrm{COD}$ and TOC Removals in Experiment 2 when $\theta_{C} \stackrel{5}{=}$ days and $\mathrm{PAC}=120 \mathrm{mg} / \mathrm{L}$

\begin{tabular}{|c|c|c|c|c|c|c|c|c|c|}
\hline \multirow[b]{2}{*}{$\begin{array}{l}\text { Run } \\
\text { No. }\end{array}$} & \multicolumn{3}{|c|}{$\mathrm{BOD}_{5}$} & \multicolumn{3}{|c|}{ COD } & \multicolumn{3}{|c|}{ TOC } \\
\hline & $\begin{array}{l}\text { Inft } \\
(\mathrm{mg} / \mathrm{L})\end{array}$ & $\begin{array}{l}\mathrm{Efft} \\
(\mathrm{mg} / \mathrm{L})\end{array}$ & $\begin{array}{r}\text { Effy } \\
(\%)\end{array}$ & $\begin{array}{l}\text { Inft } \\
(\mathrm{mg} / \mathrm{L})\end{array}$ & $\begin{array}{l}\text { Efft } \\
(\mathrm{mg} / \mathrm{L})\end{array}$ & $\begin{array}{r}\text { Effy } \\
(\%)\end{array}$ & $\begin{array}{l}\operatorname{Inft} \\
(\mathrm{mg} / \mathrm{L})\end{array}$ & $\begin{array}{l}\text { Efft } \\
(\mathrm{mg} / \mathrm{L})\end{array}$ & $\begin{array}{r}\text { Effy } \\
(\%)\end{array}$ \\
\hline 57 & 216 & 18 & 92 & 283 & 35 & 88 & 193 & 14 & 93 \\
\hline 52 & 24 & 15 & 93 & 440 & 42 & 90 & 174 & 13 & 93 \\
\hline 53 & 214 & 27 & 88 & 388 & 37 & 90 & 103 & 9 & 91 \\
\hline
\end{tabular}

Table 7.3.24 $\mathrm{BOD}_{5}, \mathrm{COD}$ and TOC Removals in Experiment 2 when $\theta_{C}=12$ days and $P A C=120 \mathrm{mg} / \mathrm{L}$

\begin{tabular}{|c|c|c|c|c|c|c|c|c|c|}
\hline \multirow[b]{2}{*}{$\begin{array}{l}\text { Run } \\
\text { No. }\end{array}$} & \multicolumn{3}{|c|}{$\mathrm{BOD}_{5}$} & \multicolumn{3}{|c|}{$\mathrm{COD}$} & \multicolumn{3}{|c|}{ TOC } \\
\hline & $\begin{array}{l}\text { In ft } \\
(\mathrm{mg} / \mathrm{L})\end{array}$ & $\begin{array}{l}\mathrm{Efft} \\
(\mathrm{mg} / \mathrm{L})\end{array}$ & $\begin{array}{r}\text { Effy } \\
(\%)\end{array}$ & $\begin{array}{l}\operatorname{Inft} \\
(\mathrm{mg} / \mathrm{L})\end{array}$ & $\begin{array}{l}\text { Efft } \\
)(m g / L)\end{array}$ & $\begin{array}{r}\text { Effy } \\
(\%)\end{array}$ & $\begin{array}{l}\text { Inft } \\
(\mathrm{mg} / \mathrm{L})\end{array}$ & $\begin{array}{l}\text { Efft } \\
(\mathrm{mg} / \mathrm{L})\end{array}$ & $\begin{array}{l}\text { Effy } \\
(\%)\end{array}$ \\
\hline 54 & 200 & 18 & 91 & 348 & 33 & 91 & 157 & 9 & 94 \\
\hline 55 & 195 & 16 & 92 & 380 & 32 & 92 & 159 & 11 & 93 \\
\hline 56 & 205 & 20 & 90 & 352 & 34 & 90 & 158 & 10 & 94 \\
\hline
\end{tabular}




\section{SLUDGE AGE}

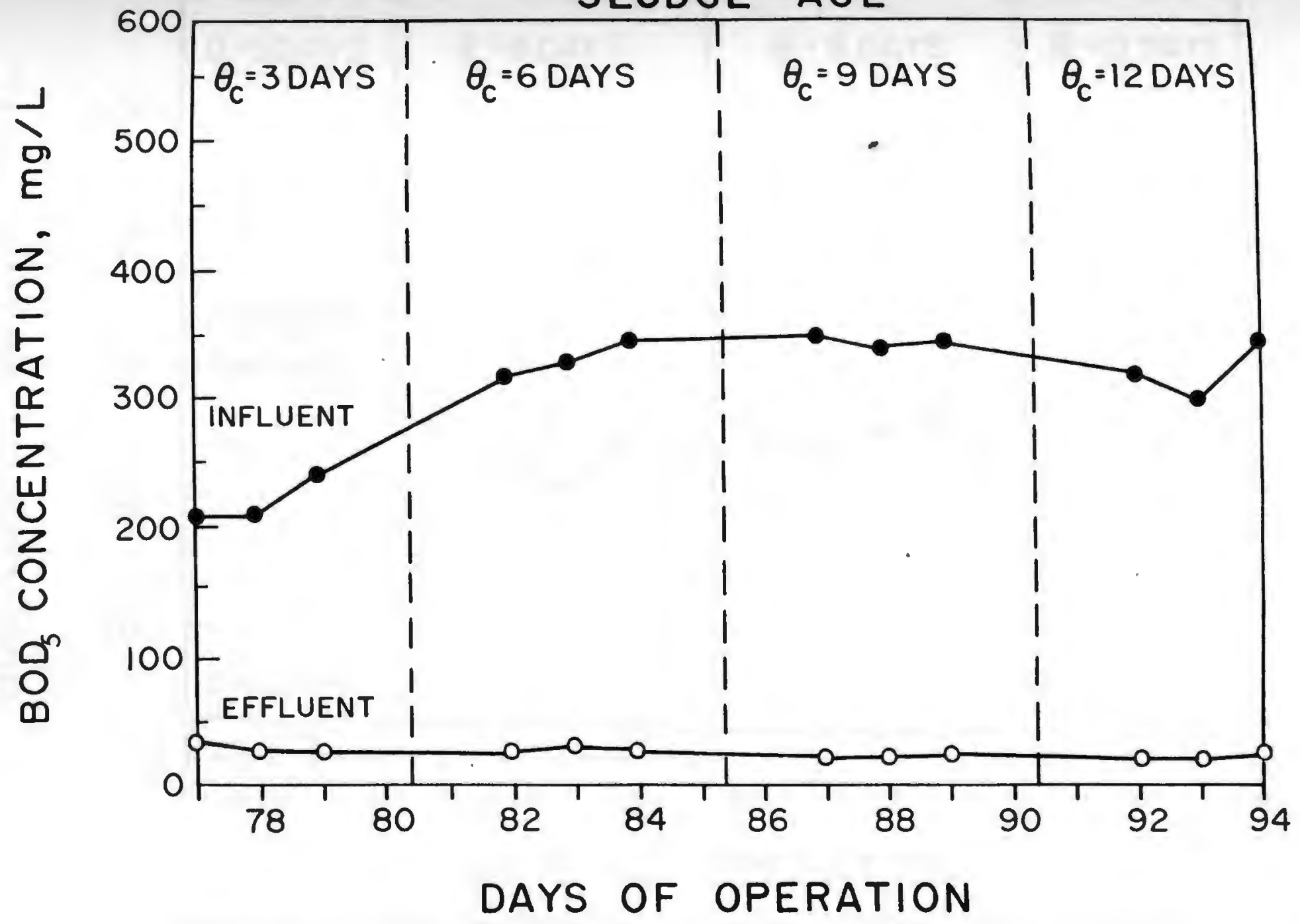

Figure 7.3 .1 BOD Removal by Activated Sludge and Powdered Activated Carbon $P A C=10 \mathrm{mg} / \mathrm{L}$ 


\section{SLUDGE AGE}

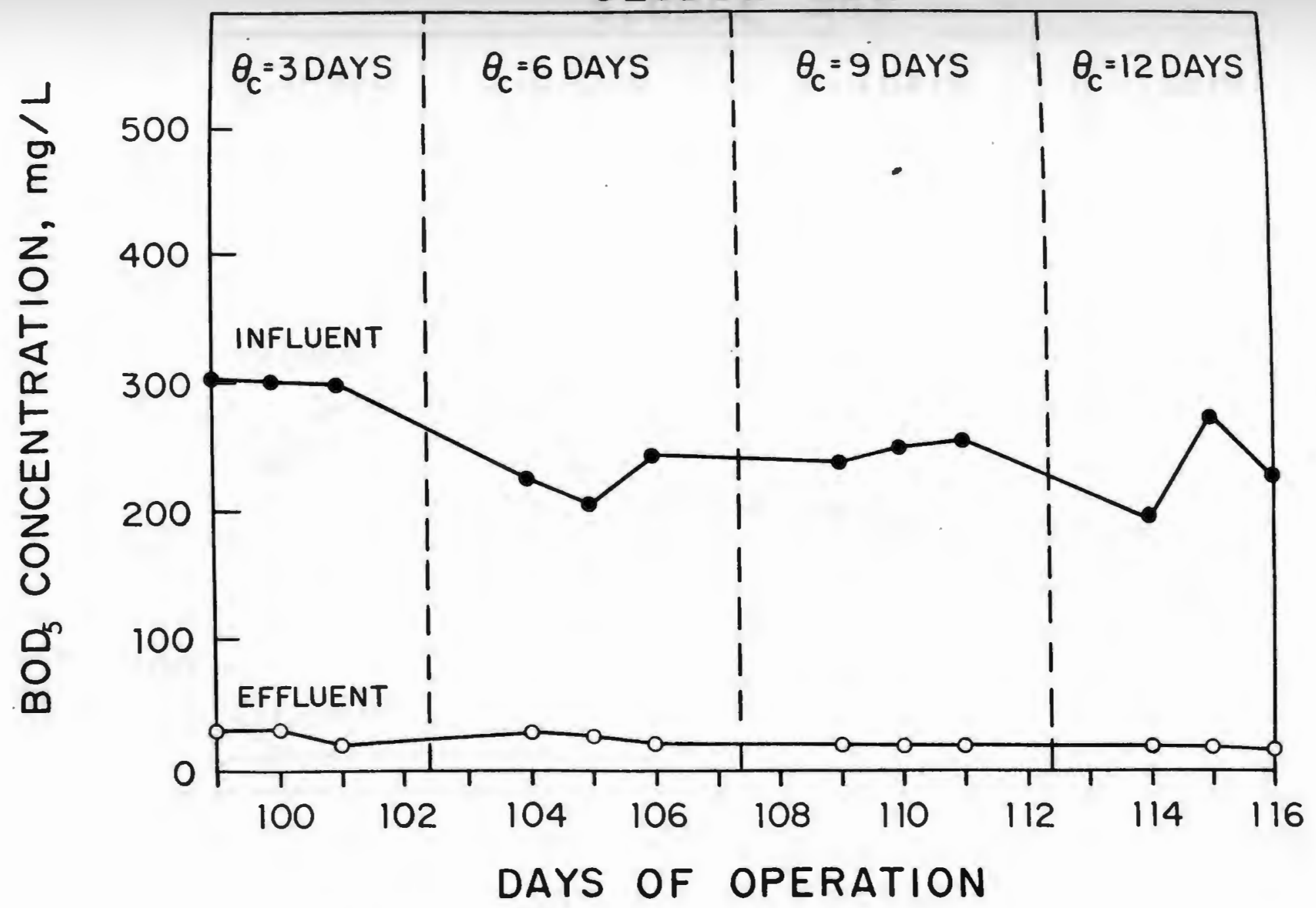

Figure 7.3.2 BOD $_{5}$ Removal by Activated sludge and Powdered Activated Carbon $\mathrm{PAC}=50 \mathrm{mg} / \mathrm{L}$ 


\section{SLUDGE AGE}

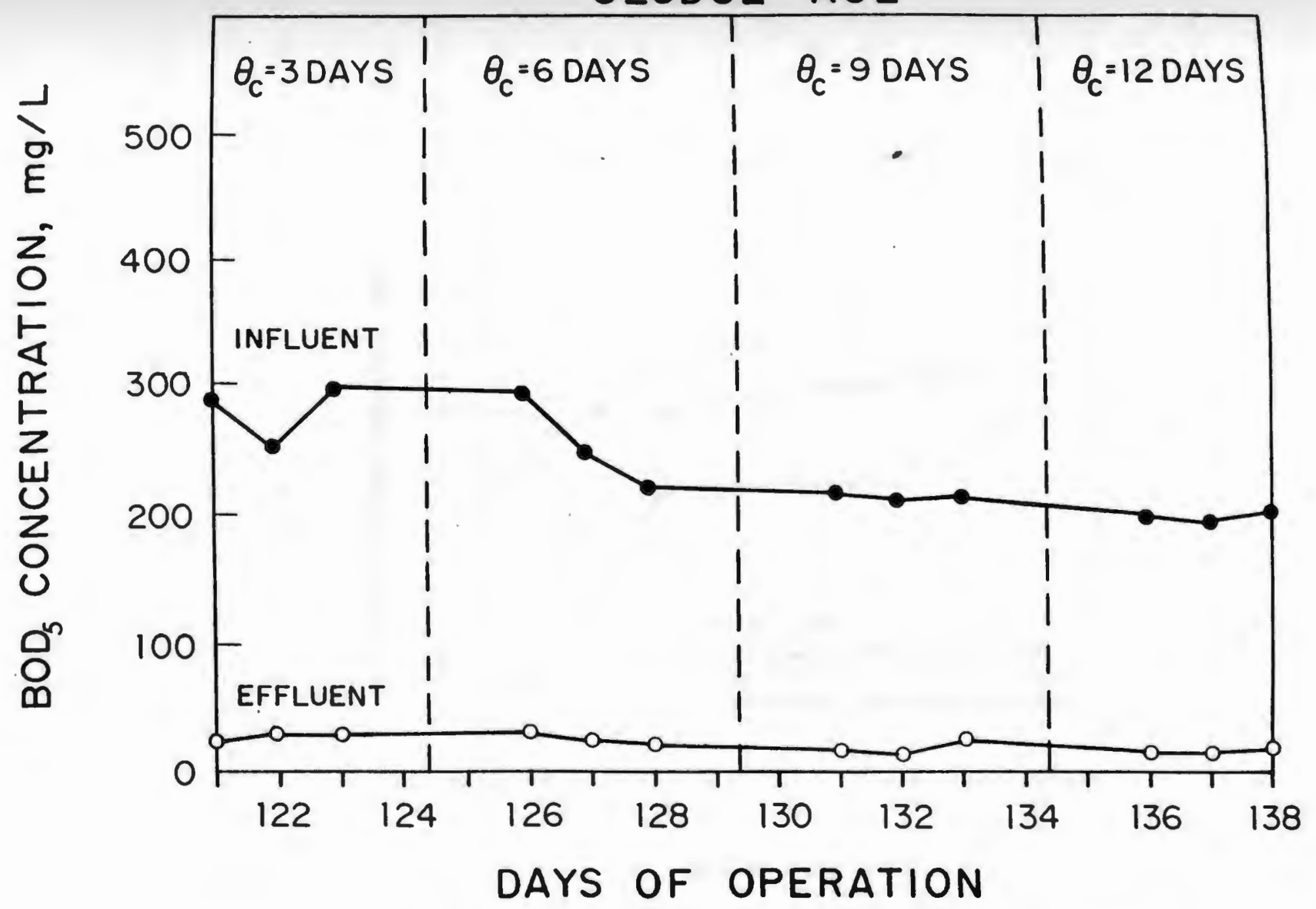

Figure 7.3.3 BOp Removal by Activated Sludge and Powdered Activated Carbon $P A C=120 \mathrm{mg} / \mathrm{L}$ 


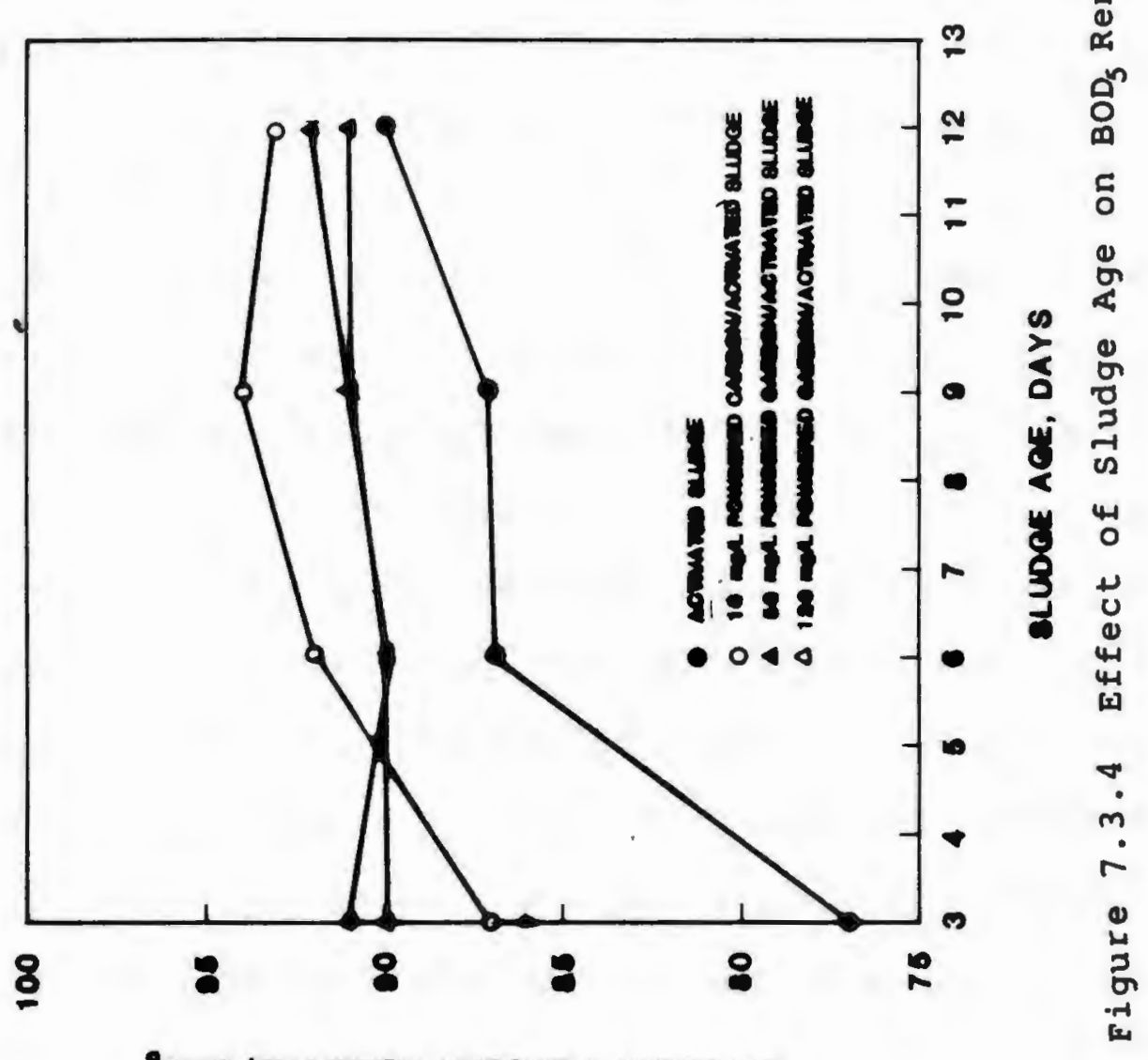

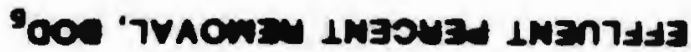


was essentially no change in the percentage removals as ${ }_{C}$ was increased. As can be seen that no change observed in the COD percent removal as $\theta_{C}$ increased from 6 days to 12 days, at a PAC concentration of $10 \mathrm{mg} / \mathrm{L}$. These data are presented in Tables 7.3.13-24. The influent and effluent concentrations versus day of operation are plotted in Figures 7.3.5-7 and $C O D$ percentage removals versus $\theta_{C}$ are plotted in Figure 7.3.8.

TOC percentage removals were increased, in comparison 'to AS, by the additions of all concentrations of PAC. The highest TOC percentage removals occurred at a PAC concentration of $120 \mathrm{mg} / \mathrm{L}$ for all $\theta_{C}$ values. In general, TOC percentage removals increased with an increase in $\theta_{C}$ for all PAC concentrations with the exception of a PAC concentration of $10 \mathrm{mg} / \mathrm{L}$. These data are presented in Tables 7.3.13-24, influent and effluent TOC concentrations versus days of operation are plotted in Figures 7.3.9-11, and effluent percentage removals versus $\theta_{C}$ are plotted in Figure 7.3.12.

Removals of priority organic pollutants $(2,4$ dimethylphenol, fluorene, naphthalene and pyrene) were investigated for various PAC reactor concentrations and sludge ages. Data for this experiment are presented in Tables 7.3.25-36 and plotted in Figures A.4.1-12.

The additions of PAC to the AS reactor resulted in a slight enhancement of 2,4 dimethylphenol removals at the 
SLUDGE AGE

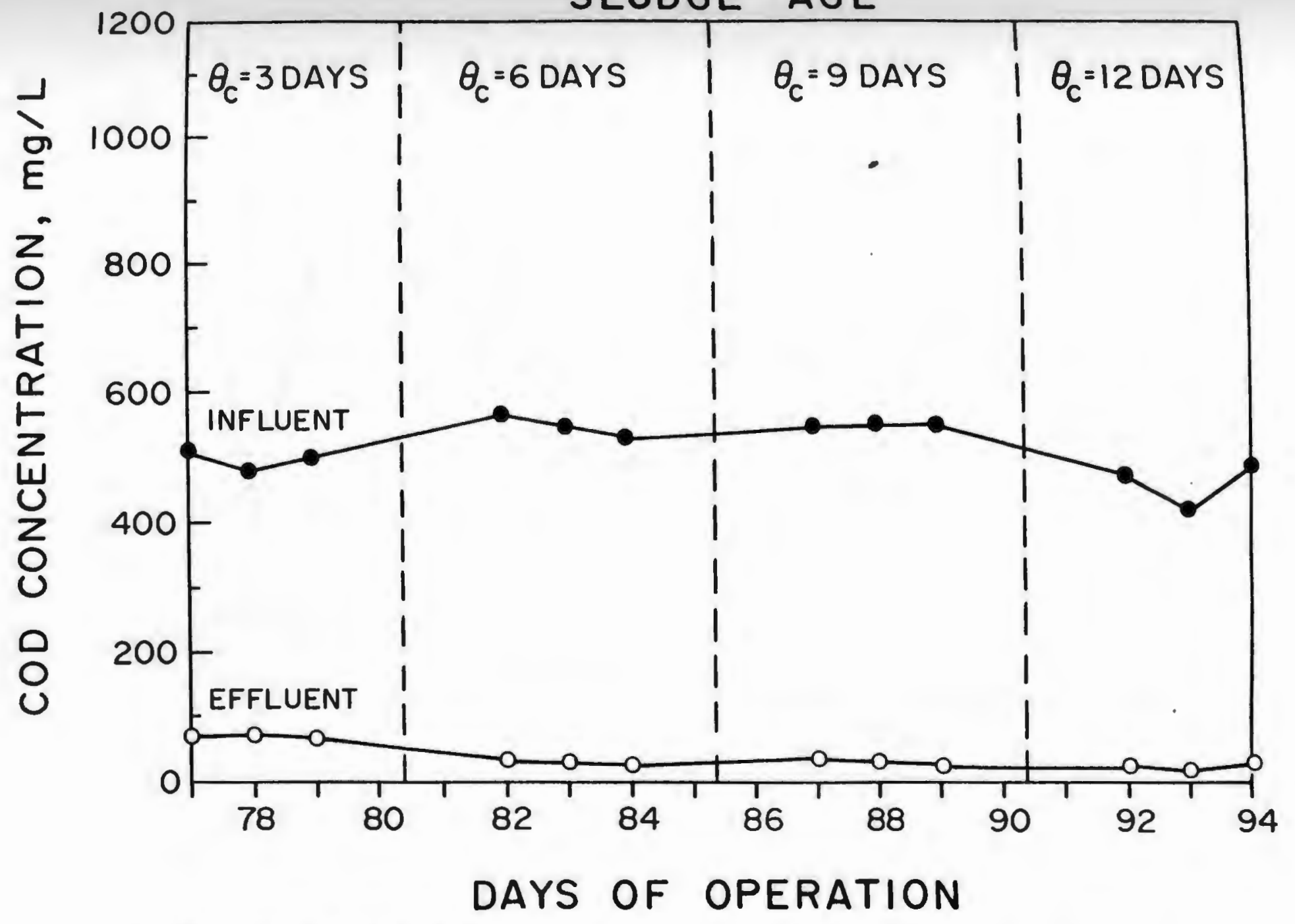

Figure 7.3 .5 COD Removal by Activated Sludge and Powdered Activated Carbon $P A C=10 \mathrm{mg} / \mathrm{L}$ 


\section{SLUDGE AGE}

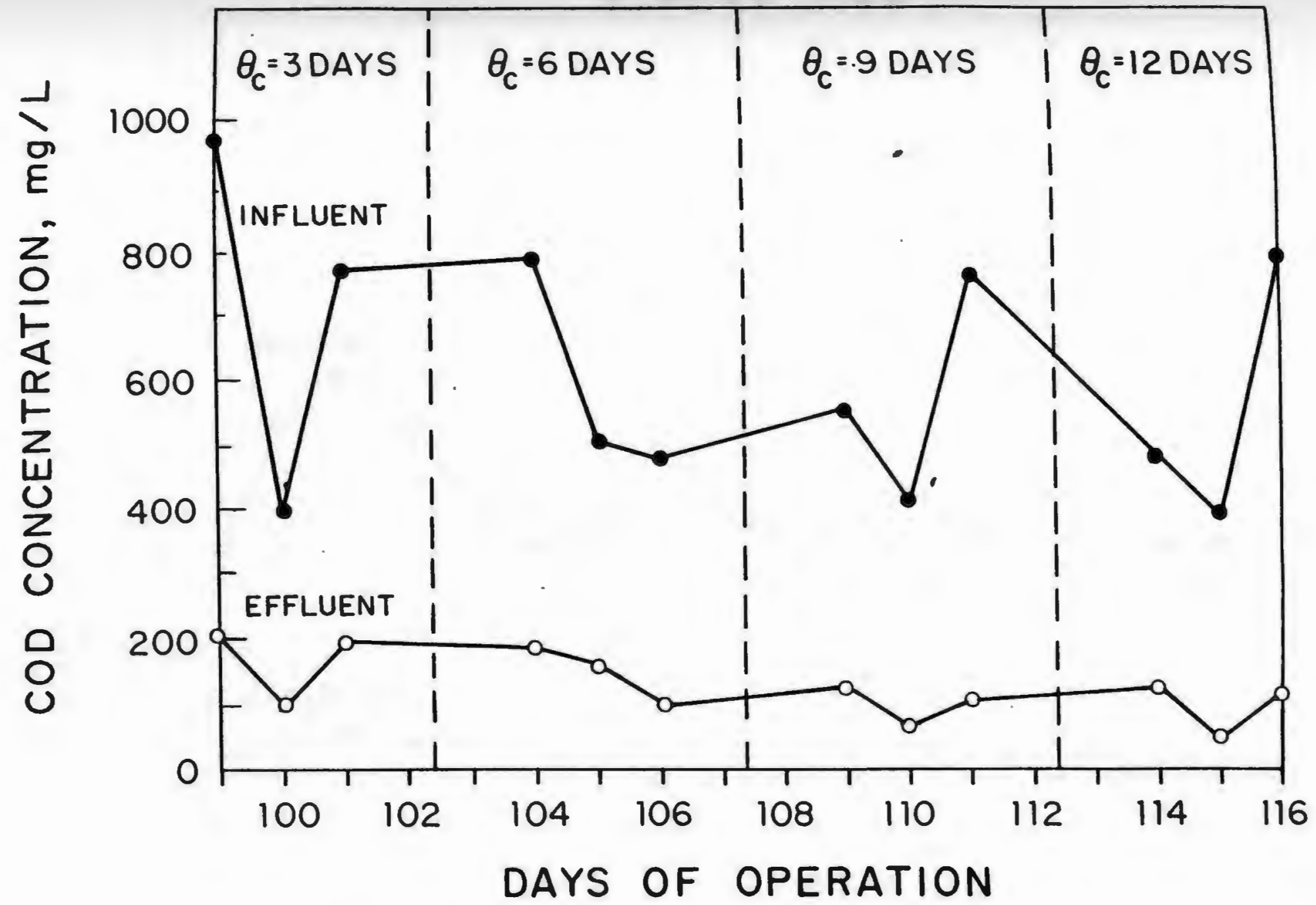

Figure 7.3 .6 COD Removal by Activated Sludge and Powdered
Activated Carbon $P A C=50 \mathrm{mg} / \mathrm{L}$ 
SLUDGE AGE

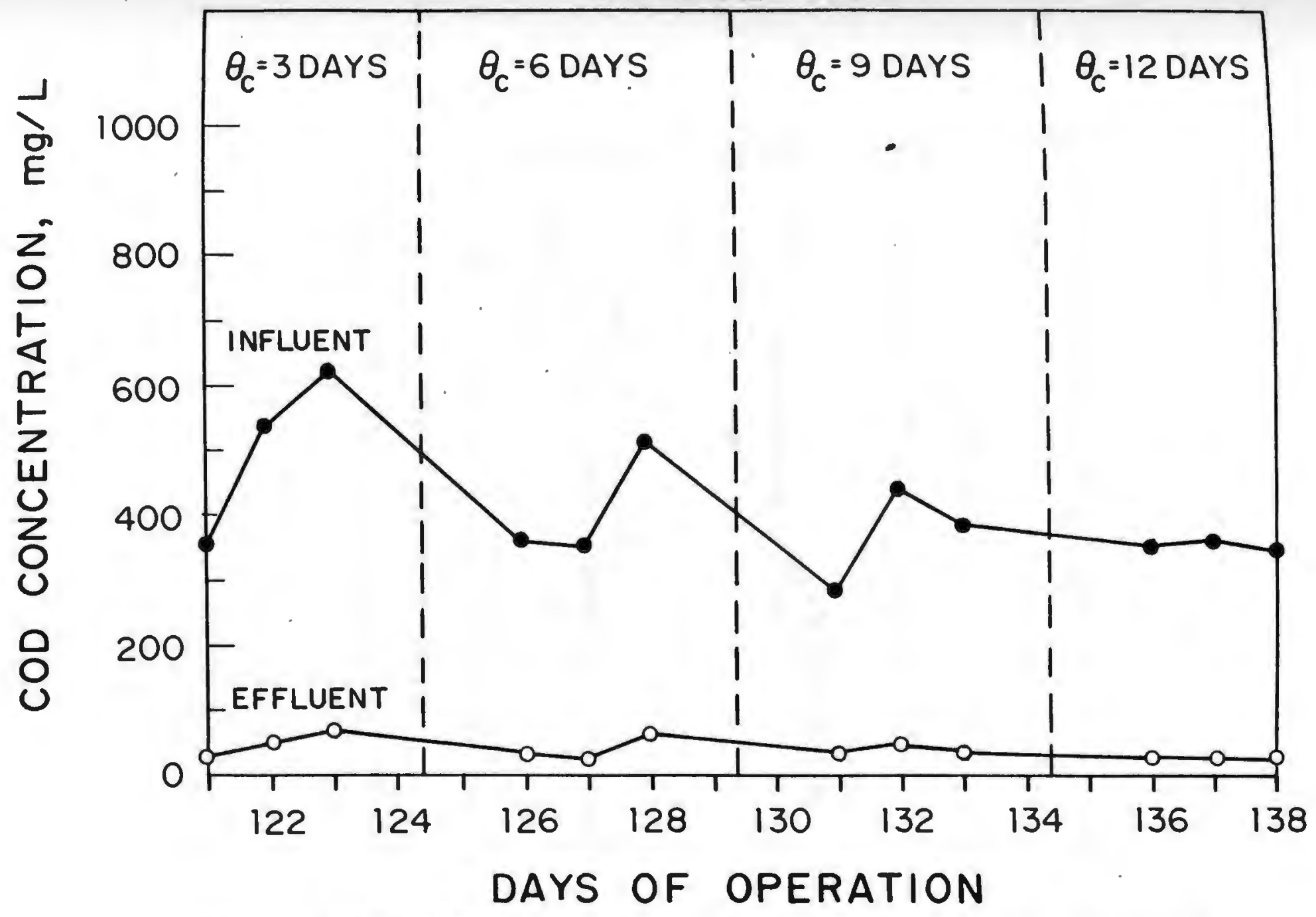

Figure 7.3 .7 COD Removal by Activated sludge and Powdered Activated Carbon $P A C=120 \mathrm{mg} / \mathrm{L}$ 


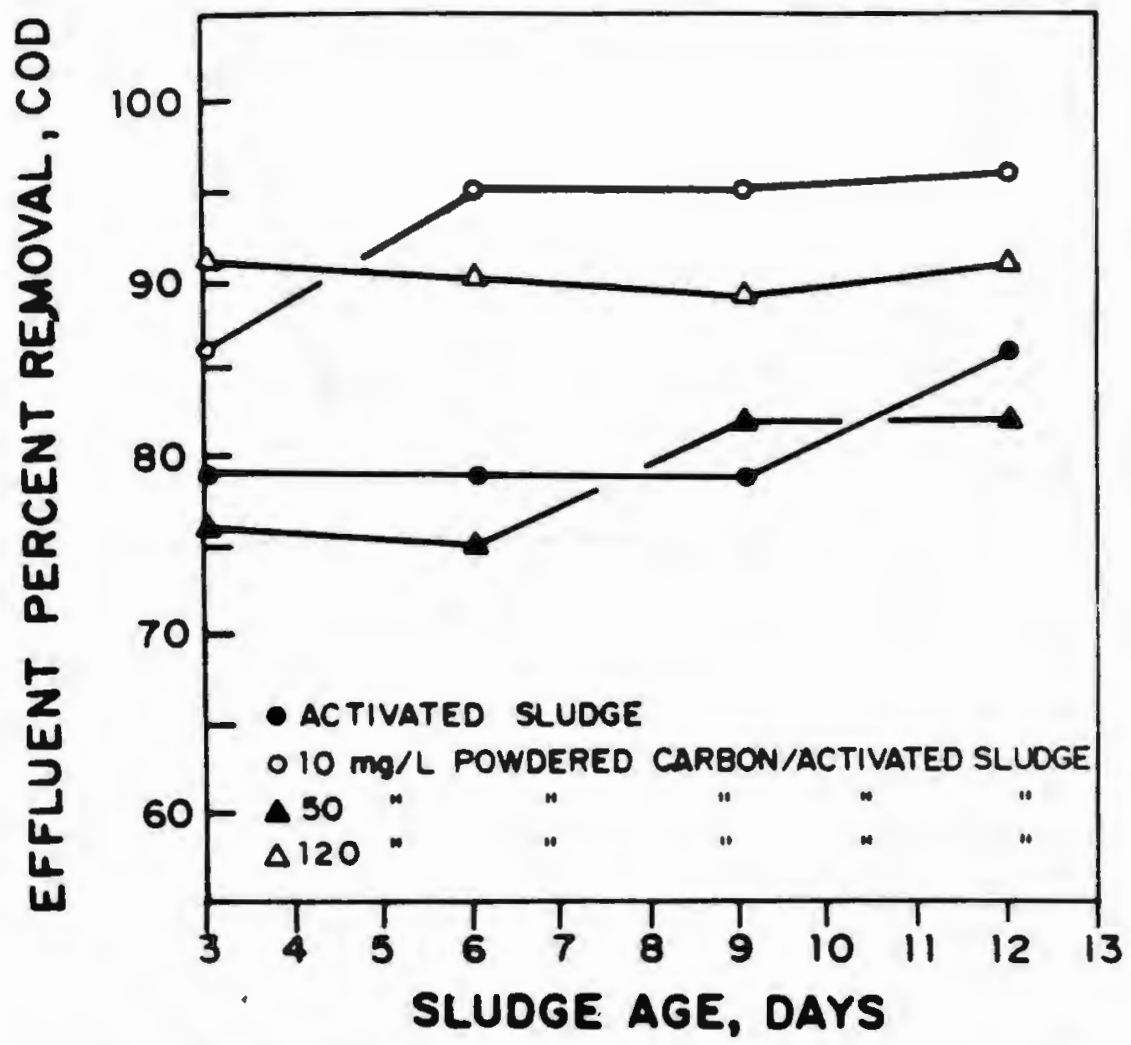

Figure 7.3.8 Effect of sludge Age on COD Removal 


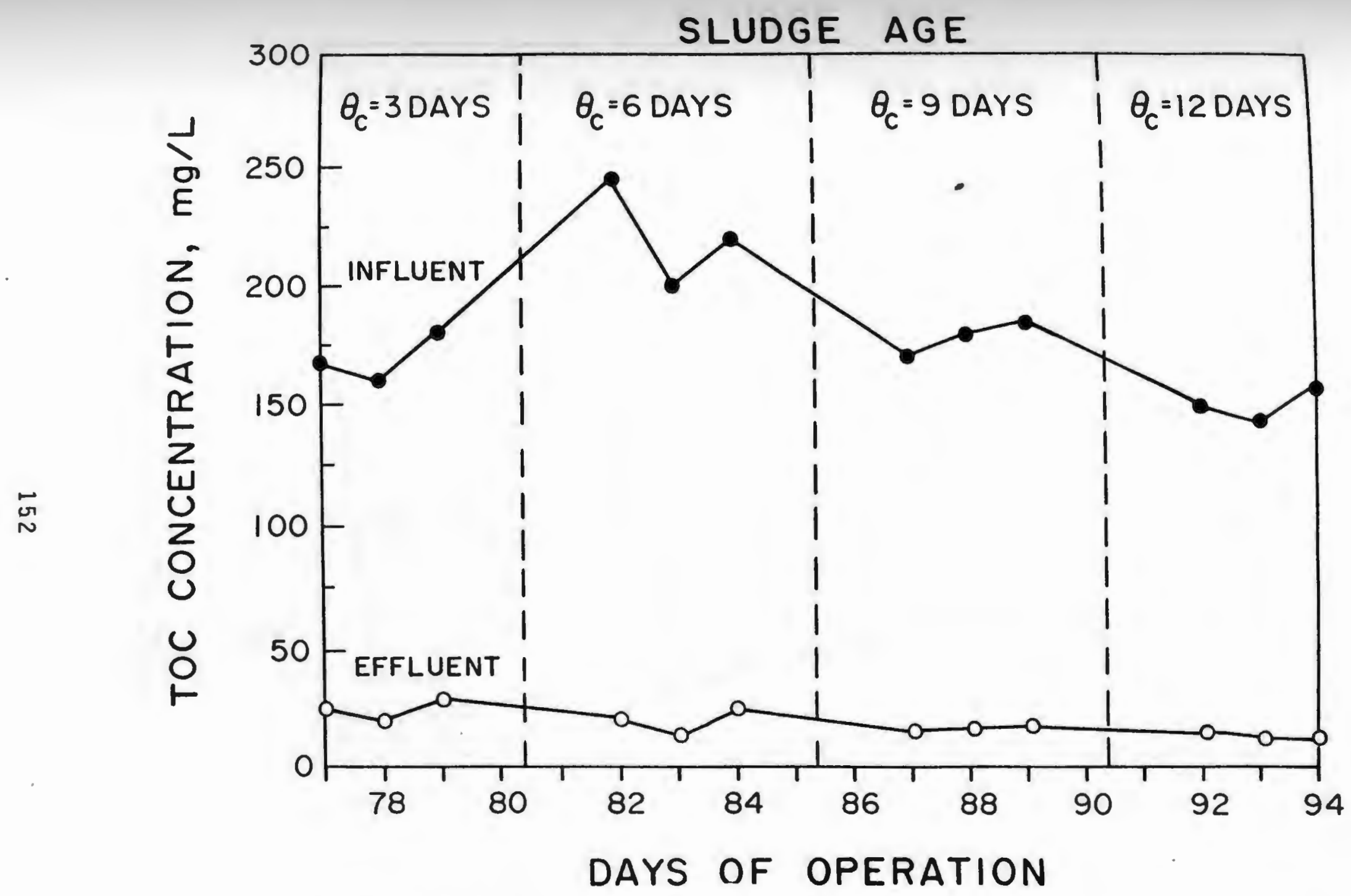

Figure 7.3.9 TOC Removal by Activated Sludge and Powdered Activated Carbon $\mathrm{PAC}=10 \mathrm{mg} / \mathrm{L}$ 


\section{SLUDGE AGE}

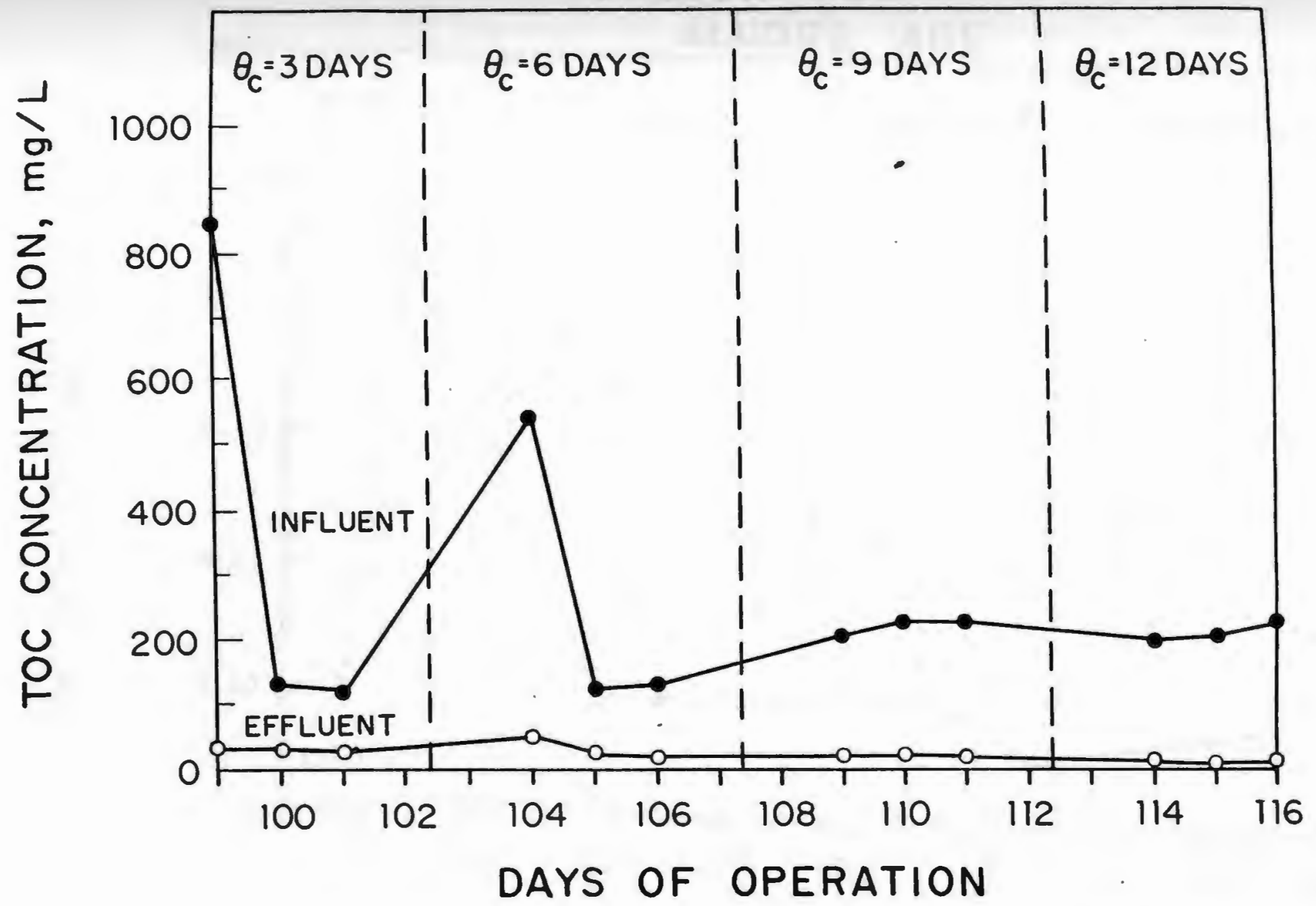

Figure 7.3.10 TOC Removal by Activated Sludge and Powdered Activated Carbon $P A C=50 \mathrm{mg} / \mathrm{L}$ 


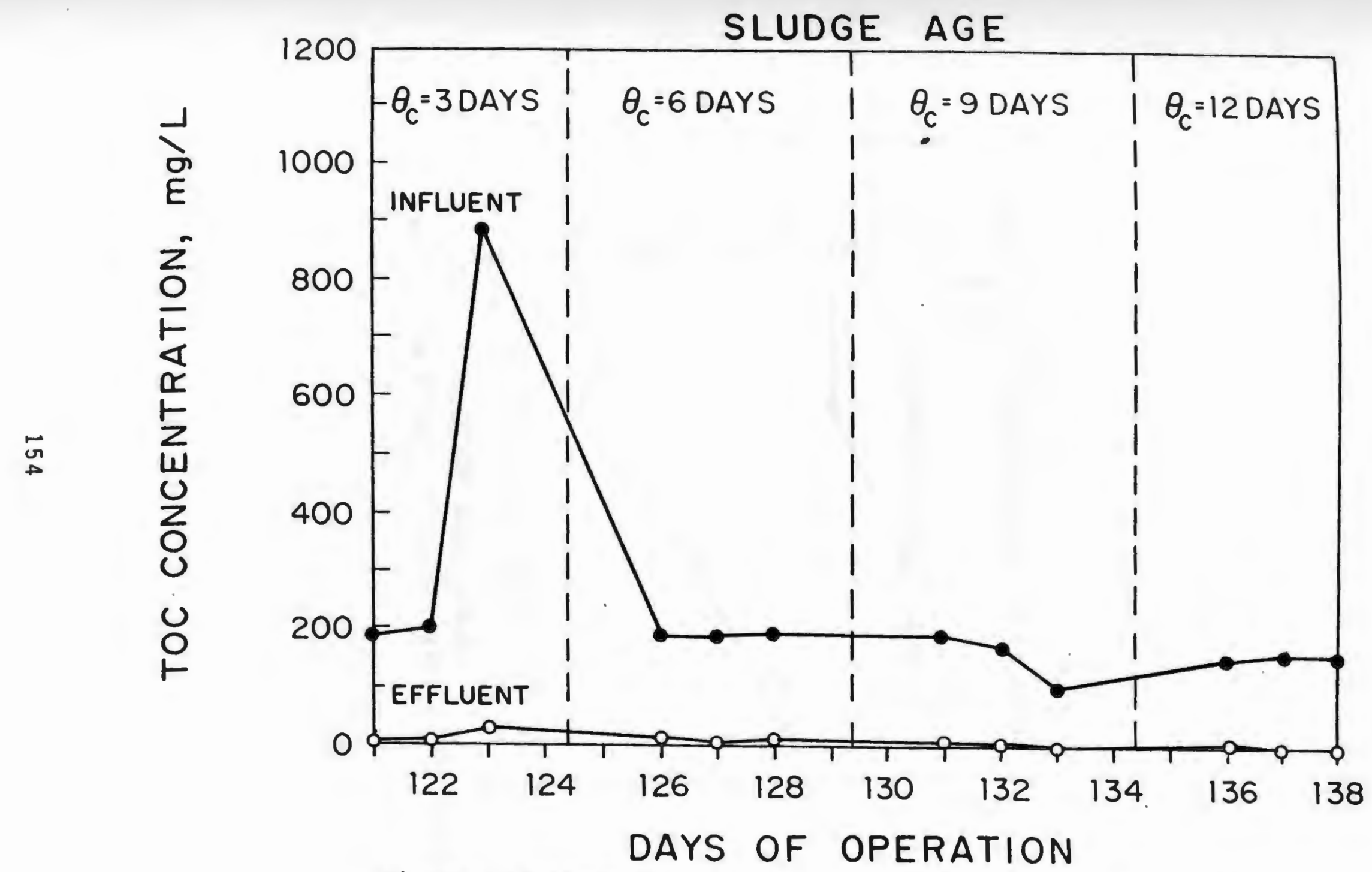
Figure 7.3.11 TOC Removal by Activated sludge and Powdered
Activated Carbon PAC $=120 \mathrm{mg} / \mathrm{L}$ 


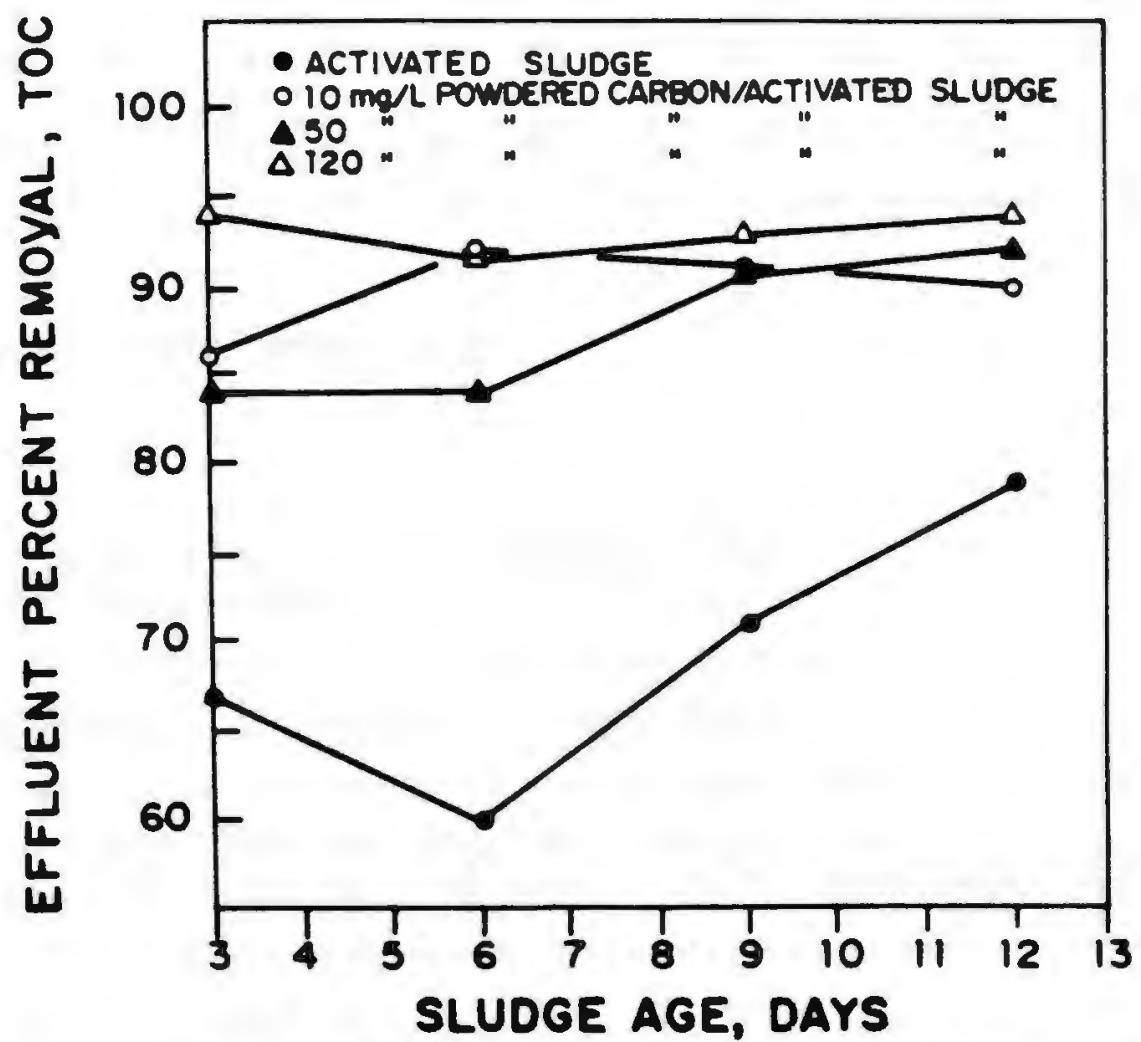

Figure 7.3.12 Effect of Sludge Age on TOC Removal 
Table 7.3.25 Priority Pollutants Ramoval, Experiment 2 when $\theta_{c}=3$ days and $P A C=10 \mathrm{mg} / \mathrm{L}$

\section{2,4-Dimethylphenol Fluorene Naphthalene Pyrene}

Run Inft Efft Effy Inft Efft Effy Inft Efft Effy Inft Efft Effy No. $(\lg / L)(\lg / L)(\%)(\lg / L)(\lg / L)(\%)(\lg / L)(\lg / L)(\%)(\lg / L)(\lg / L)(\%)$

\begin{tabular}{lllllllllllll}
\hline 21 & 87 & 27 & 69 & 33 & 16 & 52 & 107 & 27 & 75 & 27 & 20 & 26 \\
22 & 133 & 10 & 92 & 23 & 17 & 26 & 240 & 27 & 92 & $\mathrm{ND}$ & $\mathrm{NO}$ & $\mathrm{ND}$ \\
23 & 933 & 33 & 96 & 105 & 13 & 88 & 467 & 27 & 94 & 87 & 12 & 86 \\
\hline
\end{tabular}

$\mathrm{ND}=$ None detectable, detectability $>10 \mathrm{ug} / \mathrm{L}$

Table 7.3.26 Priority Pollutants Ranoval, Experiment 2 when $\theta_{C}=6$ days and $P A C=10 \mathrm{mg} / \mathrm{L}$

\section{2,4-Dimethylphenol Fluorene Naphthalene Pyrene}

Ran Inft Efft Effy Inft Efft Effy Inft Efft Effy Inft Efft Effy No. $(\lg / L)(\lg / L)(\%)(\lg / L)(\lg / L)(\%)(\lg / L)(\lg / L)(\%)(\lg / L)(\lg / L) \quad(\%)$

\begin{tabular}{lrlllllllllll}
\hline 24 & 560 & 166 & 70 & 280 & 32 & 86 & 947 & 33 & 97 & 27 & 20 & 26 \\
25 & 2,112 & 113 & 50 & 145 & 10 & 93 & 933 & 28 & 98 & 39 & 13 & 6 \\
26 & 2,848 & 140 & 50 & 93 & 39 & 58 & 733 & 19 & 84 & 30 & 26 & 13
\end{tabular}


Table 7.3.27 Priority Pollutants Removal, Experiment 2 when $\theta_{c}=9$ days and $P A C=10 \mathrm{mg} / \mathrm{L}$

2,4-Dimethylphenol Fluorene Naphthalene Pyrene

Ran Inft Efft Effy Inft Efft Effy Inft Efft Effy Inft Efft Effy

No. $(\lg / \mathrm{L})(\mathrm{Lg} / \mathrm{L})(\%)(\mathrm{Lg} / \mathrm{L})(\mathrm{Lg} / \mathrm{L})(\%)(\mathrm{Lg} / \mathrm{L})(\mathrm{Lg} / \mathrm{L})(\%)(\mathrm{Lg} / \mathrm{L})(\mathrm{Lg} / \mathrm{L})(\%)$

$\begin{array}{lllllllllllll}27 & 1,974 & 112 & 94 & 300 & 37 & 88 & 1,500 & 27 & 98 & 105 & 17 & 84\end{array}$

$\begin{array}{lllllllllllll}28 & 1,840 & 33 & 98 & 493 & 130 & 74 & 1,000 & 67 & 93 & 260 & 27 & 90\end{array}$

$\begin{array}{lllllllllllll}29 & 168 & 13 & 92 & 200 & 13 & 35 & 93 & 27 & 71 & 32 & 20 & 38\end{array}$

Table 7.3.28 Priority Pollutants Removal, Experiment 2 when $\theta_{c}=12$ days and $P A C=10 \mathrm{mg} / \mathrm{L}$

\section{2,4-Dimethylphenol Fluorene Naphtalene Pyrene}

Run Inft Efft Effy Inft Efft Effy Inft Efft Effy Inft Efft Effy

No. $(\lg / 1)(\lg / \mathrm{L})(\%)(\lg / 1)(\lg / \mathrm{L})(\%)(\lg / 1)(\lg / 1)(\%)(\lg / 1)(\lg / 1)(\%)$

\begin{tabular}{rrrrrrrrrrrrr}
\hline 30 & 3,867 & 27 & 99 & 233 & 27 & 88 & 733 & 66 & 91 & 28 & 20 & 29 \\
31 & 2,113 & 40 & 98 & 140 & 32 & 77 & 867 & 87 & 90 & 27 & 19 & 30 \\
32 & 1,700 & 33 & 98 & 207 & 40 & 81 & 1,200 & 47 & 96 & 27 & 20 & 26 \\
\hline
\end{tabular}


Table 7.3.29 Priority Pollutants Removal, Experiment when $\theta_{c}=3$ days and $\mathrm{PAC}=50 \mathrm{mg} / \mathrm{L}$

\section{2,4-Dimethylphenol Fluorene Naphthalene Pyrene}

Ran Inft Efft Effy Inft Efft Effy Inft Efft Effy Inft Efft Effy No. $(\lg / L)(\lg / L)(\%)(\lg / L)(\lg / L)(\%)(\lg / L)(\lg / L)(\%)(\lg / L)(\lg / L)(\%)$

$\begin{array}{lllllllllllll}33 & 9,933 & 140 & 99 & 279 & 57 & 80 & 7,600 & 493 & 94 & 47 & 20 & 57\end{array}$

$\begin{array}{lllllllllllll}34 & 1,500 & 32 & 98 & 167 & 35 & 79 & 1,200 & 33 & 97 & 27 & 10 & 63\end{array}$

$\begin{array}{lllllllllllll}35 & 5,333 & 80 & 99 & 128 & 10 & 92 & 853 & 40 & 5 & \text { ND } & \text { ND } & \text { ND }\end{array}$

$N=$ None detectable, detectability $>10 \mathrm{ug} / \mathrm{L}$

Table 7.3.30 Priority Pollutants Renoval, Experiment 2 when $\theta_{c}=6$ days and $\mathrm{PAC}=50 \mathrm{mg} / \mathrm{L}$

\section{2,4-Dimethylphenol Fluorene $\underline{\text { Naphthalene }}$}

Run Inft Efft Effy Inft Efft Effy Inft Efft Effy Inft Efft Effy

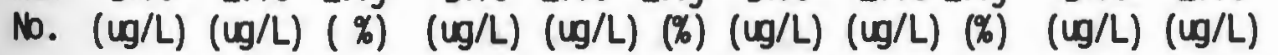

$\begin{array}{rrrrrrrrrrrrr}36 & 4,772 & 30 & 99 & 33 & \text { ND } & >70 & 1,172 & 53 & 95 & 41 & \text { ND } & >76 \\ 37 & 9,065 & 20 & 99 & 48 & \text { ND } & >79 & 40 & 13 & 68 & \text { ND } & \text { ND } & \text { N } \\ 38 & 8,720 & 12 & 99 & 147 & 57 & 61 & 1,000 & 227 & 77 & 27 & \text { ND } & >63\end{array}$

$N D=$ None detectable, detectability $>10 \mathrm{ug} / \mathrm{L}$ 
Table 7.3.31 Priority Pollutants Removal, Experiment 2 when $\theta_{c}=9$ days and $P A C=50 \mathrm{mg} / \mathrm{L}$

\section{2,4-Dimethylphenol Fluorene Naphthalene Pyrene}

Ran Inft Efft Effy Inft Efft Effy Inft Efft Effy Inft Efft Effy No. $(\lg / L)(u g / L)(\%)(u g / L)(\lg / L)(\%)(u g / L)(\operatorname{Lg} / L)(\%)(\lg / L)(\operatorname{Lg} / L)(\%)$

$\begin{array}{lllllllllllll}39 & 7,553 & 433 & 94 & 33 & \text { ND } & >70 & 733 & 203 & 72 & 31 & 15 & 52\end{array}$

$\begin{array}{lllllllllllll}40 & 3,000 & 253 & 92 & 47 & \text { ND } & >79 & 279 & \text { ND } & >96 & 22 & \text { ND } & >55\end{array}$

$\begin{array}{lllllllllllll}41 & 6,660 & 33 & 99 & 533 & \text { ND } & 98 & 733 & 158 & 78 & 27 & \text { ND } & >63\end{array}$

Table 7.3.32 Priority Pollutants Removal, Experiment 2 when $\theta_{C}=12$ days and $P A C=50 \mathrm{mg} / \mathrm{L}$

2,4-Dimethylphenol Fluorene Naphthalene Pyrene

Run Inft Efft Effy Inft Efft Effy Inft Efft Effy Inft Efft Effy

No. $(\operatorname{Lg} / L)(\lg / L)(\%)(\operatorname{Lg} / L)(\lg / L)(\%)(\lg / L)(\operatorname{Lg} / L)(\%)(\lg / L)(\lg / L)(\%)$

$\begin{array}{lllllllllllll}42 & 7,847 & 12 & 99 & 140 & 40 & 71 & 580 & 27 & 5 & 16 & 10 & 38\end{array}$

$\begin{array}{lllllllllllll}43 & 2,845 & 23 & 99 & 251 & 13 & 95 & 373 & 15 & 96 & 17 & 14 & 18\end{array}$

$\begin{array}{lllllllllllll}44 & 746 & 92 & 88 & 297 & 20 & 93 & 26 & 13 & 55 & 39 & 15 & 62\end{array}$ 
Table 7.3.33 Priority Pollutants Penoval, Experiment 2 when $\theta_{c}=3$ days and $P A C=120 \mathrm{mg} / \mathrm{L}$

\section{2,4-Dimethylphenol Fluorene Naphthalene Pyrene}

Ran Inft Efft Effy Inft Efft Effy Inft Efft Effy Inft Efft Effy

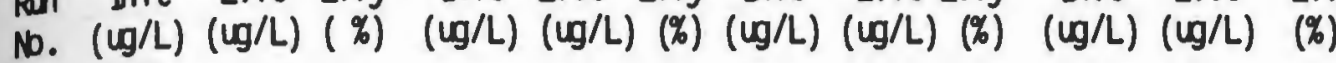

$\begin{array}{lllllllllllll}45 & 7,553 & 10 & 99 & 167 & \text { ND } & >94 & 533 & 17 & 97 & 10 & \text { ND } & -\end{array}$

$\begin{array}{lllllllllllll}46 & 7,293 & 13 & 99 & 207 & 13 & 94 & 920 & 53 & 94 & 20 & \text { ND } & >50\end{array}$

$\begin{array}{lllllllllllll}47 & 2,093 & 27 & 99 & 340 & \text { ND } & >97 & 4,667 & 27 & 99 & 40 & 12 & 70\end{array}$

$N D=$ None detectable, detectability $>10 \mathrm{ug} / \mathrm{L}$

Table 7.3.34 Priority Pollutants Renoval, Experiment 2 when $\theta_{c}=6$ days and $P A C=120 \mathrm{mg} / \mathrm{L}$

\section{2,4-Dimethylphenol Fluorene Naphthalene Pyrene}

Ran Inft Efft Effy Inft Efft Effy Inft Efft Effy Inft Efft Effy

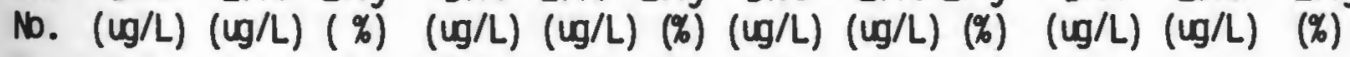

$\begin{array}{llllllllllllll}48 & 3,300 & 160 & 97 & 113 & \text { ND } & >91 & 933 & \text { ND } & >99 & 10 & \text { ND } & -\end{array}$

$\begin{array}{lllllllllllll}49 & 6,747 & 387 & 94 & 167 & 10 & 94 & 733 & \text { ND } & >99 & 13 & \text { ND } & >23\end{array}$

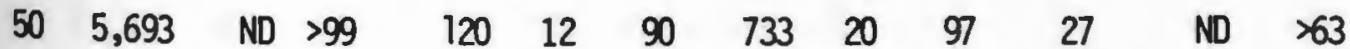

ND = None detectable, detectability $>10 \mathrm{ug} / \mathrm{L}$ 
Table 7.3.35 Priority Pollutants Renoval, Experiment 2 when $\theta_{c}=9$ days and $P A C=120 \mathrm{mg} / \mathrm{L}$

\section{2,4-Dimethylphenol Fluorene Naphthalene Pyrene}

Run Inft Efft Effy Inft Efft Effy Inft Efft Effy Inft Efft Effy

No. $(\lg / L)(\lg / L)(\%)(\lg / L)(\lg / L)(\%)(\lg / L)(\lg / L)(\%)(\lg / L)(\lg / L)(\%)$

$\begin{array}{lllllllllllll}51 & 6,473 & 17 & 99 & 153 & \text { ND } & >93 & 733 & 47 & 94 & 17 & \text { ND } & >44\end{array}$

$\begin{array}{lllllllllllll}52 & 4,187 & 17 & 99 & 73 & N D & >86 & 293 & 16 & 95 & 87 & N & >77\end{array}$

$\begin{array}{lllllllllllll}53 & 3,953 & 33^{\circ} & 99 & 207 & 13 & 94 & 257 & 13 & 95 & 13 & \text { ND } & >23\end{array}$

$N D=$ None detectable, detectability $>10 \mathrm{ug} / \mathrm{L}$

Table 7.3.36 Priority Pollutants Removal, Experiment 2 when $\theta_{c}=12$ days and $P A C=120 \mathrm{mg} / \mathrm{L}$

\section{2,4-Dimethylphenol \\ Fluorene \\ Naphthalene \\ Pyrene}

Run Inft Efft Effy Inft Efft Effy Inft Efft Effy Inft Efft Effy

Nb. $(\lg / L)(\lg / L)(\%)(\lg / L)(\lg / L)(\%)(\lg / L)(\lg / L)(\%)(\lg / L)(\lg / L)$

(\%)

$\begin{array}{lllllllllllll}54 & 6,613 & 327 & 95 & 133 & 20 & 85 & 293 & 17 & 94 & 27 & \text { ND } & >63\end{array}$

$\begin{array}{lllllllllllll}55 & 5,200 & 33 & 99 & 67 & 17 & 75 & 200 & \text { ND } & >95 & 27 & 12 & 56\end{array}$

$\begin{array}{lllllllllllll}56 & 11,367 & 667 & 94 & 47 & \text { ND } & >79 & 2,467 & 127 & 95 & 33 & 11 & 67\end{array}$

$N D=$ None detectable, detectability $>10 \mathrm{ug} / \mathrm{L}$ 
50 and $120 \mathrm{mg} / \mathrm{L}$ PAC concentrations at all sludge ages over the removals obtained from the AS alone. There appeared to be no advantages in terms of 2,4 dimethylphenol removals to maintaining a long $\theta_{c}$ with the exception of a PAC concentration of $10 \mathrm{mg} / \mathrm{L}$.

Fluorene percentage removals could only be increased over that resulting from AS alone by a PAC concentration of $120 \mathrm{mg} / \mathrm{L}$ in the AS reactor. There appeared to be no trend which could be observed of percentage removals of fluorene versus $\theta_{C}$.

As was the case for fluorene, the percentage removals of naphthalene only showed an enhancement over the AS removals at a PAC concentration of $120 \mathrm{mg} / \mathrm{L}$. Changes in $\theta_{c}$ did not appear to improve the percentage removals of napthalene.

No percentage removal trends in terms of PAC concentrations and $\theta_{c}$ values could be observed for pyrene.

The results of the study on the removals of the volatile compounds (benzene, chloroform, ethylbenzene, toluene, $m-x y l e n e$ and $0-x y l e n e)$ are presented in Tables 7.3.37-48. Since these compounds were studied in section 7.5 and found to be air stripped from the reactor by the air flow, there were no increases expected and no increases observed in the percentage removals of the volatile compounds due to the addition of PAC to the AS reactor. 
Table 7.3.37 Volatile arganics Removal, Experiment 2 when $\theta_{C}=3$ days, $P A C=10 \mathrm{mg} / \mathrm{L}$

\begin{tabular}{|c|c|c|c|c|c|c|c|c|c|c|c|c|c|c|c|c|c|}
\hline \multirow[b]{2}{*}{$\begin{array}{l}\text { Run } \\
\text { Nb. }\end{array}$} & \multirow[b]{2}{*}{$\begin{array}{c}\text { Inft } \\
(u g / L)\end{array}$} & Berzene & \multicolumn{3}{|c|}{ Chloroform } & \multicolumn{3}{|c|}{ Ethylberzene } & \multicolumn{3}{|c|}{ Toluene } & \multicolumn{3}{|c|}{ M-xylene } & \multicolumn{3}{|c|}{ Q-xylene } \\
\hline & & $\begin{array}{l}\text { Efft Et } \\
(u g / L)\end{array}$ & $\begin{array}{l}\text { Effy Inft } \\
(\%)(u g / L)\end{array}$ & $\begin{array}{l}\text { Efft } \\
\text { (ug/L) }\end{array}$ & $\begin{array}{l}\text { Effy } \\
(\%)\end{array}$ & $\begin{array}{l}\text { Inft } \\
\text { (ug/L) }\end{array}$ & $\begin{array}{l}\text { Efft } \\
\text { (ug/L) }\end{array}$ & $\begin{array}{r}\text { Effy } \\
(\%)\end{array}$ & $\begin{array}{l}\text { Inft } \\
\text { (ug/L) }\end{array}$ & $\begin{array}{c}\text { Efft } \\
\text { (ug/L) }\end{array}$ & $\begin{array}{l}\text { Effy } \\
\text { (\%) }\end{array}$ & $\begin{array}{l}\text { Inft } \\
\text { (ug/L) }\end{array}$ & $\begin{array}{c}\text { Efft } \\
\text { (ug/L) }\end{array}$ & $\begin{array}{l}\text { Effy } \\
(\%)\end{array}$ & $\begin{array}{l}\text { Inft } \\
\text { (ug/L) }\end{array}$ & $\begin{array}{l}\text { Efft } \\
\text { (ug/L) }\end{array}$ & $\begin{array}{l}\text { Effy } \\
(\%)\end{array}$ \\
\hline 21 & 4,367 & ND $>$ & $>992,692$ & 500 & 81 & 1,333 & ND & $>99$ & 2,983 & N & $>99$ & 1483 & ND & $>99$ & 3,498 & ND & $>99$ \\
\hline 22 & 3,300 & 20 & 992,503 & $2 \pi$ & 89 & 630 & 30 & 95 & 2,183 & 18 & 99 & 940 & ND & $>99$ & 490 & ND & $>98$ \\
\hline 23 & 3,065 & ND & $>992,439$ & 512 & 80 & 1,040 & ND & $>99$ & 4,080 & ND & $>99$ & 1,251 & NO & $>99$ & 2,750 & ND & $>99$ \\
\hline
\end{tabular}

$\mathrm{ND}=$ None detectable, detectability $>10 \mathrm{ug} / \mathrm{L}$ 
Table 7.3.38 Volatile arganics Removal, Experiment 2 when $\theta_{C}=6$ days, $P A C=10 \mathrm{mg} / \mathrm{L}$

\begin{tabular}{|c|c|c|c|c|c|c|c|c|c|c|c|c|c|c|c|c|}
\hline \multirow[b]{2}{*}{$\begin{array}{l}\text { Rin } \\
\text { No. }\end{array}$} & \multirow[b]{2}{*}{$\begin{array}{r}\text { Inft } \\
(u g / L)\end{array}$} & Benzene & \multicolumn{2}{|c|}{ Chlorofonn } & \multicolumn{3}{|c|}{ Ethylbenzene } & \multicolumn{3}{|c|}{ Toluene } & \multicolumn{3}{|c|}{ M-Xylene } & \multicolumn{3}{|c|}{ O-xylene } \\
\hline & & $\begin{array}{l}\text { Efft Effy Inft } \\
(u g / L) \quad(\%)(u g / L)\end{array}$ & $\begin{array}{l}\text { Efft } \\
(\mathrm{ug} / \mathrm{L})\end{array}$ & $\begin{array}{l}\text { Effy } \\
(\%)\end{array}$ & $\begin{array}{c}\text { Inft } \\
(\mathrm{ug} / L)\end{array}$ & $\begin{array}{l}\text { Efft } \\
(u g / L)\end{array}$ & $\begin{array}{l}\text { Effy } \\
\text { (\%) } 1\end{array}$ & $\begin{array}{l}\text { Inft } \\
(\mathrm{ug} / \mathrm{L})\end{array}$ & $\begin{array}{c}E f f t \\
(u g / L)\end{array}$ & $\begin{array}{l}\text { Effy } \\
(\%)\end{array}$ & $\begin{array}{c}\text { Inft } \\
(\mathrm{ug} / \mathrm{L})\end{array}$ & $\begin{array}{l}\text { Efft } \\
(u g / L)\end{array}$ & $\begin{array}{l}\text { Effy } \\
(\%)\end{array}$ & $\begin{array}{l}\text { Inft } \\
(\mathrm{ug} / \mathrm{L})\end{array}$ & $\begin{array}{l}\text { Efft } \\
(\mathrm{ug} / \mathrm{L})\end{array}$ & Effy \\
\hline 24 & 4,379 & ND >99 2,593 & 90 & 97 & 1,125 & ND & $>99$ & 2,883 & $3 \mathrm{ND}$ & 100 & 3,274 & ND & 100 & 4,442 & ND & $>99$ \\
\hline 25 & 4,216 & N D >99 2,445 & 325 & 87 & 1,578 & $\mathbf{N D}$ & $>99$ & 3,950 & $0 \quad N$ & 100 & 2,863 & ND & 100 & 5,081 & ND & $>99$ \\
\hline 26 & 3,941 & $N$ D $>992,596$ & 325 & 87 & 1,656 & ND & $>99$ & 3,067 & 7 ND & 100 & 700 & ND & 100 & 1,899 & ND: & $>99$ \\
\hline
\end{tabular}

$\mathbf{N}=$ None detectable, detectability $>10 \mathrm{ug} / \mathrm{L}$ 
Table 7.3.39 Volatile organics Renoval, Experiment 2, when $\theta_{c}=9$ days, PAC $=10 \mathrm{mg} / \mathrm{L}$

\begin{tabular}{|c|c|c|c|c|c|c|c|c|c|c|c|c|c|c|c|c|c|}
\hline \multirow[b]{2}{*}{$\begin{array}{l}\text { Ren } \\
\text { No. }\end{array}$} & \multirow[b]{2}{*}{$\begin{array}{c}\text { Inft } \\
(\mathrm{ug} / L)\end{array}$} & Benzene & \multicolumn{3}{|c|}{ Chloroform } & \multicolumn{3}{|c|}{ Ethylbenzene } & \multicolumn{3}{|c|}{ Toluene } & \multicolumn{3}{|c|}{ M-xylene } & \multicolumn{3}{|c|}{ 0-xylene } \\
\hline & & $\begin{array}{l}\text { Efft } \\
(\mathrm{ug} / \mathrm{L})\end{array}$ & $\begin{array}{l}\text { Effy Inft } \\
(\%)(\mathrm{ug} / \mathrm{L})\end{array}$ & $\begin{array}{c}\text { Efft } \\
(u g / L)\end{array}$ & $\begin{array}{l}\text { Effy } \\
(\%)\end{array}$ & $\begin{array}{c}\text { Inft } \\
(\mathrm{ug} / \mathrm{L})\end{array}$ & $\begin{array}{c}\text { Efft } \\
(u g / L)\end{array}$ & $\begin{array}{r}\text { Effy } \\
(\%)\end{array}$ & $\begin{array}{c}\text { Inft } \\
(\mathrm{ug} / \mathrm{L})\end{array}$ & $\begin{array}{c}\text { Efft } \\
(u g / L)\end{array}$ & $\begin{array}{l}\text { Effy } \\
(\%)\end{array}$ & $\begin{array}{l}\text { Inft } \\
(\mathrm{ug} / \mathrm{L})\end{array}$ & $\begin{array}{c}\text { Efft } \\
(\mathrm{ug} / \mathrm{L})\end{array}$ & $\begin{array}{l}\text { Effy } \\
\text { (\%) }\end{array}$ & $\begin{array}{l}\text { Inft } \\
(\mathrm{ug} / L)\end{array}$ & $\begin{array}{l}\mathrm{Efft} \\
(\mathrm{ug} / \mathrm{L})\end{array}$ & $\begin{array}{l}\text { Effy } \\
(\%)\end{array}$ \\
\hline 27 & 2,430 & ND $>$ & $>992,145$ & 130 & 94 & 1,027 & ND & $>99$ & 1,600 & ND & $>99$ & 660 & ND & $>98$ & 960 & ND & $>99$ \\
\hline 28 & 1,600 & ND & $>991,442$ & 20 & 99 & 938 & ND & $>99$ & 1,500 & N & $>99$ & 630 & ND & $>98$ & 700 & ND & $>99$ \\
\hline 29 & 2,011 & ND $>$ & $>991,929$ & 240 & 88 & 190 & ND & $>95$ & 1,142 & ND & $>99$ & 560 & ND & $>98$ & 1,130 & ND & $>99$ \\
\hline
\end{tabular}

$\mathrm{ND}=$ None detectable, detectability $>10 \mathrm{ug} / \mathrm{L}$ 
Table 7.3.40 Volatile Organics Removal, Experiment 2, when $\theta_{C}=12$ days, $P A C=10 \mathrm{mg} / \mathrm{L}$

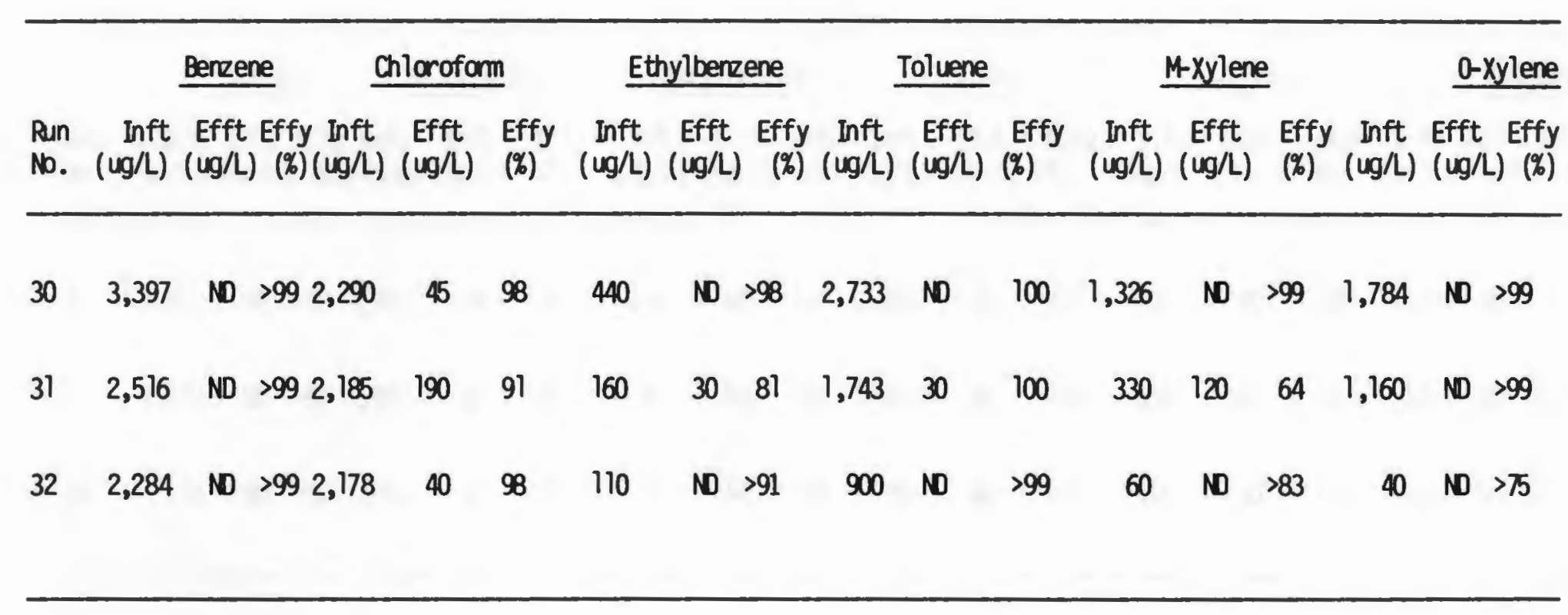

ND $=$ None detectable, detectability $>10 \mathrm{ug} / \mathrm{L}$ 
Table 7.3.41 Volatile Organics Removal, Experiment 2, when $\theta_{C}=3$ days, $P A C=50 \mathrm{mg} / \mathrm{L}$

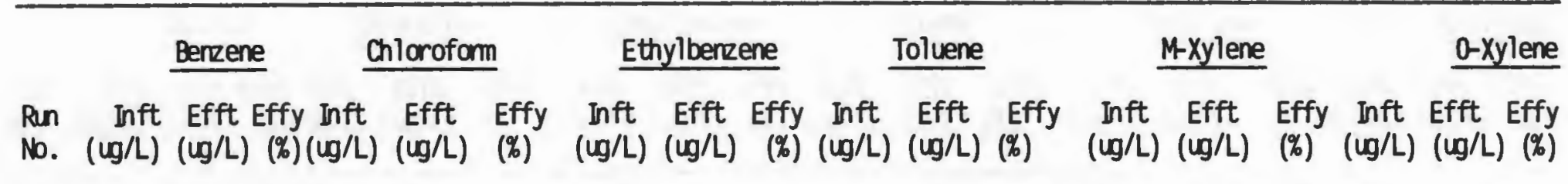

\begin{tabular}{|c|c|c|c|c|c|c|c|c|c|c|c|c|c|c|c|c|c|c|}
\hline \multirow{3}{*}{$\vec{a}$} & 33 & 3,487 & ND & $>991,950$ & 18 & 99 & 392 & ND & $>97$ & 2,283 & ND & $>99$ & 500 & ND & $>98$ & 1,020 & ND & $>99$ \\
\hline & 34 & 2,919 & ND & $>991,995$ & ND & 99 & 200 & ND & $>95$ & 1,967 & ND & $>99$ & 850 & $\mathrm{MD}$ & $>99$ & 1,470 & ND & $>99$ \\
\hline & 35 & 910 & ND & $>991,796$ & 10 & 99 & 10 & ND & ND & 380 & ND & $>97$ & 418 & ND & $>98$ & 280 & $\mathrm{ND}$ & $>96$ \\
\hline
\end{tabular}

ND = None detectable, detectability $>10 \mathrm{ug} / \mathrm{L}$ 
Table 7.3.42 Volatile Organics Ramoval, Experiment 2 when $\theta_{C}=6$ days, $\mathrm{PAC}=50 \mathrm{mg} / \mathrm{L}$

\begin{tabular}{|c|c|c|c|c|c|c|c|c|c|c|c|c|c|c|c|c|c|}
\hline \multirow[b]{2}{*}{$\begin{array}{l}\text { Run } \\
\mathrm{Nb} \text {. }\end{array}$} & \multirow[b]{2}{*}{$\begin{array}{c}\text { Inft } \\
(\mathrm{ug} / \mathrm{L})\end{array}$} & Benzene & \multicolumn{3}{|c|}{ Chloroform } & \multicolumn{3}{|c|}{ Ethylberzene } & \multicolumn{3}{|c|}{ Toluene } & \multicolumn{3}{|c|}{ M-Xylene } & \multicolumn{3}{|c|}{ O-xylene } \\
\hline & & $\begin{array}{l}\text { Efft } \\
\text { (ug/L) }\end{array}$ & $\begin{array}{l}\text { Effy Inft } \\
\text { (\%) (ug/L) }^{2}\end{array}$ & $\begin{array}{c}\text { Efft } \\
\text { (ug/L) }\end{array}$ & $\begin{array}{l}\text { Effy } \\
\text { (\%) }\end{array}$ & $\begin{array}{c}\text { Inft } \\
\text { (ug/L) }\end{array}$ & $\begin{array}{c}\text { Efft } \\
\text { (ug/L) }\end{array}$ & $\begin{array}{r}\text { Effy } \\
(\%)\end{array}$ & $\begin{array}{c}\text { Inft } \\
\text { (ug/L) }\end{array}$ & $\begin{array}{c}\text { Efft } \\
\text { (ug/L) }\end{array}$ & $\begin{array}{l}\text { Effy } \\
\text { (\%) }\end{array}$ & $\begin{array}{l}\text { Inft } \\
(u g / L)\end{array}$ & $\begin{array}{c}\text { Efft } \\
\text { (ug/L) }\end{array}$ & $\begin{array}{l}\text { Effy } \\
\text { (\%) }\end{array}$ & $\begin{array}{l}\text { Inft } \\
\text { (ug/L) }\end{array}$ & $\begin{array}{l}\text { Efft } \\
\text { (ug/L) }\end{array}$ & $\begin{array}{l}\text { Effy } \\
(\%)\end{array}$ \\
\hline 36 & 2,708 & $N$ & $>992,106$ & 22 & 99 & 378 & ND & 297 & 1,600 & ND & $>99$ & 413 & $\mathbf{N}$ & $>98$ & 800 & $\mathbf{N D}$ & $>99$ \\
\hline 37 & 2,805 & ND & $>992,085$ & 80 & 96 & 660 & ND & $>98$ & 1,917 & ND & $>99$ & 700 & ND & $>991$ & 1,200 & ND & $>99$ \\
\hline 38 & 3,065 & ND & $>992,132$ & 21 & 99 & 690 & ND & $>99$ & 2,283 & N & $>99$ & 1,233 & $N$ & $>992$ & 2,171 & ND & $>99$ \\
\hline
\end{tabular}

ND = None detectable, detectability >10 ug/L 
Table 7.3.43 Volatile Organics Removal, Experiment 2, when $\theta_{C}=9$ days, PAC $=50 \mathrm{mg} / \mathrm{L}$

\begin{tabular}{|c|c|c|c|c|c|c|c|c|c|c|c|c|c|c|c|c|c|}
\hline \multirow[b]{2}{*}{$\begin{array}{l}\text { Aun } \\
\text { No. }\end{array}$} & \multirow[b]{2}{*}{$\begin{array}{r}\text { Inft } \\
(\mathrm{ug} / \mathrm{L})\end{array}$} & Benzene & \multicolumn{3}{|c|}{ Chlorofom } & \multicolumn{3}{|c|}{ Ethylberzene } & \multicolumn{2}{|r|}{ Toluene } & \multicolumn{4}{|c|}{ M-Xylene } & \multicolumn{3}{|c|}{$\underline{0-x y l e}$} \\
\hline & & $\begin{array}{l}\text { Efft } \\
\text { (ug/L) }\end{array}$ & $\begin{array}{l}\text { Effy Inft } \\
\text { (\%) (ug/L) }\end{array}$ & $\begin{array}{c}\text { Efft } \\
(\mathrm{ug} / \mathrm{L})\end{array}$ & $\begin{array}{l}\text { Effy } \\
(\%)\end{array}$ & $\underset{(\lg / L)}{\operatorname{lnft}}$ & $\begin{array}{c}\text { Efft } \\
(\mathrm{Lg} / \mathrm{L})\end{array}$ & $\begin{array}{r}\text { Effy } \\
(\%)\end{array}$ & $\begin{array}{l}\text { Inft } \\
(\mathrm{Lg} / \mathrm{L})\end{array}$ & $\begin{array}{c}\text { Efft } \\
(\mathrm{ug} / \mathrm{L})\end{array}$ & $\begin{array}{l}\text { Effy } \\
(\%)\end{array}$ & $\begin{array}{c}\operatorname{lnft} \\
(\lg / L)\end{array}$ & $\begin{array}{l}\text { Efft } \\
\text { (ug/L) }\end{array}$ & $\begin{array}{l}\text { Effy } \\
(\%)\end{array}$ & $\begin{array}{l}\operatorname{Inft} \\
(\mathrm{Lg} / \mathrm{L})\end{array}$ & $\begin{array}{l}\text { Efft } \\
(\mathrm{ug} / \mathrm{L}\end{array}$ & $\begin{array}{l}\text { Eff }) \\
\text { L) }(\%)\end{array}$ \\
\hline 39 & 2,530 & ND & $>992,043$ & 20 & 99 & 100 & ND & $>90$ & 1,998 & ND & $>99$ & 340 & ND & $>97$ & 100 & N & $>90$ \\
\hline 40 & 2,592 & ND & $>992,025$ & 130 & 93 & 560 & ND & $>98$ & 1,850 & 10 & 99 & 800 & ND & $>99$ & 870 & ND & $>99$ \\
\hline 41 & 2,661 & ND & $>992,092$ & 20 & 99 & 330 & ND & $>97$ & 2,050 & ND & $>99$ & 1,217 & ND & $>992$ & 2,013 & $N$ & $>99$ \\
\hline
\end{tabular}

$\mathrm{ND}=$ None detectable, detectability $>10 \mathrm{ug} / \mathrm{L}$ 
Table 7.3.44 Volatile Organics Removal, Experiment 2, when $\theta_{C}=12$ days, PAC $=50 \mathrm{mg} / \mathrm{L}$

Benzene chloroform Ethylbenzene toluene M-Xylene $\quad \underline{0-x y l e n e}$

Ran Inft Efft Effy Inft Efft Effy Inft Efft Effy Inft Efft Effy Inft Efft Effy Inft Efft Effy

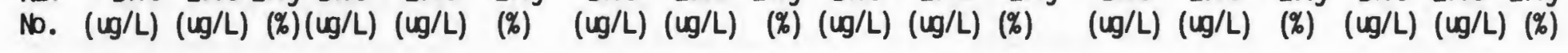

$\begin{array}{rrrllllllllllllllllllll}42 & 1,411 & 20 & 99 & 1,800 & 10 & 99 & 470 & N D & >98 & 740 & N D & >99 & 719 & N D & >99 & 140 & N D & >93 \\ 43 & 144 & N D & >93 & 1,912 & 20 & 99 & 178 & N D & >94 & 920 & N D & >99 & 500 & N D & >98 & 1,040 & N D & >99\end{array}$

$N D=$ None detectable, detectability $>10 \mathrm{ug} / \mathrm{L}$ 
Table 7.3.45 Volatile organics Removal, Experiment 2 when $\theta_{C}=3$ days, $P A C=120 \mathrm{mg} / \mathrm{L}$

\begin{tabular}{|c|c|c|c|c|c|c|c|c|c|c|c|c|c|c|c|c|c|}
\hline \multirow[b]{2}{*}{$\begin{array}{l}\text { Pun } \\
\text { No. }\end{array}$} & \multirow[b]{2}{*}{$\begin{array}{c}\text { Inft } \\
\text { (ug/L) }\end{array}$} & \multicolumn{2}{|c|}{ Benzene } & \multicolumn{2}{|c|}{ Chioroform } & \multicolumn{3}{|c|}{ Ethylbenzene } & \multicolumn{3}{|c|}{ Toluene } & \multicolumn{3}{|c|}{ M-Xylene } & \multicolumn{3}{|c|}{$\underline{0-x y l e n e}$} \\
\hline & & $\begin{array}{l}\mathrm{Efft} \\
\text { (ug/L) }\end{array}$ & $\begin{array}{l}\text { Effy Inft } \\
\text { (\%)(ug/L) }\end{array}$ & $\begin{array}{c}\text { Efft } \\
\text { (ug/L) }\end{array}$ & $\begin{array}{l}\text { Effy } \\
\text { (\%) }\end{array}$ & $\begin{array}{c}\text { Inft } \\
\text { (ug/L) }\end{array}$ & $\begin{array}{c}\text { Efft } \\
\text { (ug/L) }\end{array}$ & $\begin{array}{r}\text { Effy } \\
(\%)\end{array}$ & $\begin{array}{l}\text { Inft } \\
\text { (ug/L) }\end{array}$ & $\begin{array}{c}\text { Efft } \\
\text { (ug/L) }\end{array}$ & $\begin{array}{l}\text { Effy } \\
(\%)\end{array}$ & $\begin{array}{c}\text { Inft } \\
(\text { ug/L) }\end{array}$ & $\begin{array}{l}\text { Efft } \\
\text { (ug/L) }\end{array}$ & $\begin{array}{l}\text { Effy } \\
(\%)\end{array}$ & $\begin{array}{l}\text { Inft } \\
(\mathrm{ug} / \mathrm{L})\end{array}$ & $\begin{array}{l}\text { Efft } \\
\text { (ug/L) }\end{array}$ & $\begin{array}{r}\text { Effy } \\
(\%)\end{array}$ \\
\hline 45 & 1,719 & ND & $>992,145$ & ND & $>99$ & 200 & ND & $>95$ & 1,383 & ND & $>99$ & 648 & ND & $>98$ & 1,240 & ND & $>99$ \\
\hline 46 & 1,190 & ND & $>991,968$ & ND & $>99$ & 300 & ND & $>97$ & 1,020 & ND & $>99$ & 480 & ND & $>98$ & 848 & N & $>99$ \\
\hline 47 & 2,741 & ND & $>992,426$ & 30 & 99 & 300 & ND & 297 & 1,600 & ND & $>99$ & 620 & ND & $>98$ & 890 & ND & $>99$ \\
\hline
\end{tabular}

$N D=$ None detectable, detectability $>10 \mathrm{ug} / \mathrm{L}$ 
Table 7.3.46 Volatile Organics Removal, Experiment 2, when $\theta_{c}=6$ days, PAC $=120 \mathrm{mg} / \mathrm{L}$

\begin{tabular}{|c|c|c|c|c|c|c|c|c|c|c|c|c|c|c|c|c|c|}
\hline \multirow[b]{2}{*}{$\begin{array}{l}\text { Run } \\
\text { No. }\end{array}$} & \multirow[b]{2}{*}{$\begin{array}{c}\text { Inft } \\
(\mathrm{ug} / \mathrm{L})\end{array}$} & Benzene & \multicolumn{3}{|c|}{ Chlorofom } & \multicolumn{3}{|c|}{ Ethylbenzene } & \multicolumn{3}{|c|}{ Toluene } & \multicolumn{3}{|c|}{ M-xylene } & \multicolumn{3}{|c|}{ 0-xylene } \\
\hline & & $\begin{array}{l}\text { Efft } \\
(\omega g / L)\end{array}$ & $\begin{array}{l}\text { Effy Inft } \\
(\%)(\mathrm{g} / \mathrm{L})\end{array}$ & $\begin{array}{c}\text { Efft } \\
(\mathrm{ug} / \mathrm{L})\end{array}$ & $\begin{array}{l}\text { Effy } \\
(\%)\end{array}$ & $\begin{array}{l}\text { Inft } \\
(\mathrm{ug} / \mathrm{L})\end{array}$ & $\begin{array}{l}\text { Efft } \\
(\mathrm{ug} / \mathrm{L})\end{array}$ & $\begin{array}{r}\text { Effy } \\
(\%)\end{array}$ & $\begin{array}{l}\text { Inft } \\
(\mathrm{gg} / \mathrm{L})\end{array}$ & $\begin{array}{l}\text { Efft } \\
(\mathrm{Lg} / \mathrm{L})\end{array}$ & $\begin{array}{l}\text { Effy } \\
\text { (\%) }\end{array}$ & $\begin{array}{c}\text { Inft } \\
(u g / L)\end{array}$ & $\begin{array}{l}\text { Efft } \\
(\mathrm{ug} / \mathrm{L})\end{array}$ & $\begin{array}{l}\text { Effy } \\
(\%)\end{array}$ & $\begin{array}{l}\text { Inft } \\
(\lg / L)\end{array}$ & $\begin{array}{l}\text { Efft } \\
(\mathrm{Lg} / \mathrm{L})\end{array}$ & $\begin{array}{l}\text { Effy } \\
(\%)\end{array}$ \\
\hline 48 & 960 & ND & $>992,069$ & ND & $>99$ & 120 & ND & $>92$ & 270 & ND & $>96$ & 40 & ND & $>75$ & 110 & ND & $>96$ \\
\hline 49 & 1,816 & ND & $>992,229$ & 10 & 99 & 122 & ND & $>92$ & 970 & N & $>99$ & 410 & ND & $>98$ & 550 & ND & $>98$ \\
\hline 50 & 2,430 & ND & $>992,345$ & 38 & 98 & 140 & ND & $>931$ & 1,360 & ND & $>99$ & 750 & ND & $>99$ & 850 & M & $>99$ \\
\hline
\end{tabular}

$N D=$ None detectable, detectability $>10 \mathrm{ug} / \mathrm{L}$ 
Table 7.3.47 Volatile organics Removal, Experiment 2, when $\theta_{C}=9$ days, $P A C=120 \mathrm{mg} / \mathrm{L}$

\begin{tabular}{|c|c|c|c|c|c|c|c|c|c|c|c|c|c|c|c|c|c|}
\hline \multirow[b]{2}{*}{$\begin{array}{l}\text { Run } \\
\text { No. }\end{array}$} & \multirow[b]{2}{*}{$\begin{array}{r}\text { Inft } \\
(\operatorname{Lg} / L)\end{array}$} & Berzene & \multicolumn{3}{|c|}{ Chloroform } & \multicolumn{3}{|c|}{ Ethyibenzene } & \multicolumn{2}{|r|}{ Toluene } & \multicolumn{4}{|c|}{ M-Xylene } & \multirow[b]{2}{*}{$\begin{array}{l}\text { Inft } \\
(\lg / L)\end{array}$} & \multicolumn{2}{|c|}{ 0-xylene } \\
\hline & & $\begin{array}{l}\text { Efft } \\
(\mathrm{ug} / \mathrm{L})\end{array}$ & $\begin{array}{l}\text { Effy Inft } \\
(\%)(\mathrm{ug} / \mathrm{L})\end{array}$ & $\begin{array}{c}\text { Efft } \\
(\mathrm{ug} / \mathrm{L})\end{array}$ & $\begin{array}{l}\text { Effy } \\
(\%)\end{array}$ & $\begin{array}{l}\text { Inft } \\
(\operatorname{ug} / L)\end{array}$ & $\begin{array}{l}\text { Efft } \\
(\mathrm{ug} / L)\end{array}$ & $\begin{array}{r}\text { Effy } \\
(\%)\end{array}$ & $\begin{array}{c}\text { Inft } \\
\text { (ug/L) }\end{array}$ & $\begin{array}{c}\text { Efft } \\
(u g / L)\end{array}$ & $\begin{array}{l}\text { Effy } \\
(\%)\end{array}$ & $\begin{array}{l}\text { Inft } \\
(\mathrm{ug} / \mathrm{L})\end{array}$ & $\begin{array}{l}\text { Efft } \\
(u g / L)\end{array}$ & $\begin{array}{l}\text { Effy } \\
(\%)\end{array}$ & & $\begin{array}{l}\text { Efft } \\
(u g / L)\end{array}$ & $\begin{array}{l}\text { Effy } \\
(\%)\end{array}$ \\
\hline 51 & 1,573 & ND & $>992,45$ & 78 & 97 & 482 & ND & $>98$ & 740 & ND & $>99$ & 500 & N & $>98$ & 220 & ND & $>95$ \\
\hline 52 & 810 & ND: & $>991,926$ & ND & $>99$ & 20 & ND & $>50$ & 280 & N & $>96$ & 260 & $N$ & $>96$ & 410 & NO & $>98$ \\
\hline 53 & 810 & ND & $>99 \quad 1,924$ & ND & $>99$ & 50 & ND & 280 & 383 & ND & $>97$ & 190 & ND & $>95$ & 240 & N & $>96$ \\
\hline
\end{tabular}

$\mathrm{ND}=$ None detectable, detectability $>10 \mathrm{ug} / \mathrm{L}$ 
Table 7.3.48 Volatile Organics Removal, Experiment 2, when $\theta_{C}=12$ days, $P A C=120 \mathrm{mg} / \mathrm{L}$

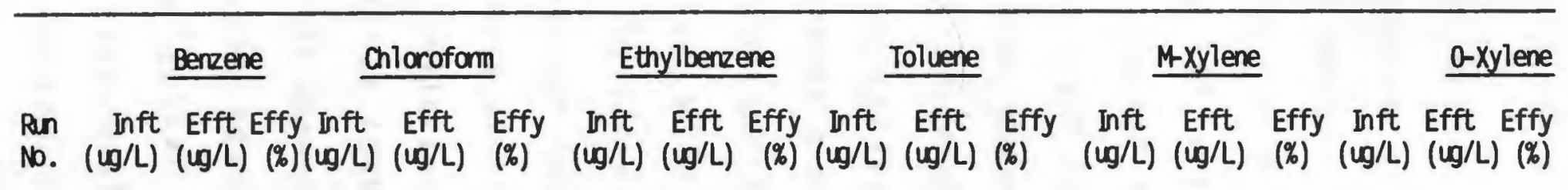

$\stackrel{乛}{Ð}$

$\begin{array}{llllllllllllllllllllll}54 & 1,020 & N D & >99 & 2,180 & 60 & 97 & 50 & 10 & 80 & 383 & N D & >97 & 325 & N D & >97 & 520 & N D & >98 \\ 55 & 940 & N D & >99 & 2,253 & 10 & 99 & 30 & N D & >67 & 385 & N D & >97 & 220 & N D & >95 & 280 & N D & >96 \\ 56 & 2,238 & N D & >99 & 2,283 & 60 & 97 & 300 & N D & >97 & 1,417 & N D & >97 & 1,040 & N D & >99 & 1,658 & N D & >99\end{array}$

$\mathrm{ND}=$ None detectable, detectability $>10 \mathrm{ug} / \mathrm{L}$ 
7.4 Evaluation of Biological Growth in Experiments 1 and 2

\subsubsection{Light Microscopic Analysis}

one important method for determining the viability of and any visible changes in the AS microbial population is an examination by use of a light microscope. Throughout the duration of this study, daily samples of the AS biomass were collected from the reactor and immediately viewed under the light microscope.

Chronological observations of the AS biomass were used by several researchers to document the acclimation period that is typically required for industrial biological treatment processes. Reitano (54) in a study to measure the potential of the AS process to treat a refinery waste, utilized a periodic microscopic examination of the biomass to determine the length of the acclimation phase for the bacteria.

The AS biomass utilized in each of of the experiments was originally collected from the South kingstown Waste Treatment Facility (SKWTF) prior to the start of this study. An initial observation of this biomass immediately after collection revealed a diverse population of microorganisms typical of those found in a domestic AS including bacteria, rotifers, algae, fungi and ciliates.

The As biomass collected from the SKWTF was transferred into the pilot-scale reactor and fed with the 
industrial refinery wastewater. After 24 hours of operation there was a decrease in the AS biomas population density from an initial MLVSS concentration in the range of $1,800 \mathrm{mg} / \mathrm{L}$ to approximately $250 \mathrm{mg} / \mathrm{L}$ MLVSS. An examination under the light microscope after 24 hours of operation revealed a high percentage of protozoa followed by ciliates and bacteria.

A photomicrograph of the AS sample which was examined on day 2 of operation is shown in figure 7.4.1.1. This photomicrdgraph represents a typical microorganism population consisting primarily of protozoa. themselves, protozoa consume bacteria and suspended organic matter and thus do not directly metabolize the dissolved organic fraction.

After two weeks of operation the MLVSS showed a slight increase from 1,520 to $1,596 \mathrm{mg} / \mathrm{L}$. During this operational time the biomass was in a period of acclimation with an apparant mass balance between the dying microorganisms and the acclimated organisms. Not only was there a slight change in the total mass of microorganisms, but there was also a rearrangement in the types of microorganisms. A decrease in the number of protozoa and a corresponding increase in both the number of ciliates and the bacteria in the AS sludge was noted. Examples of the typical microorganisms present after two weeks of operation are shown in Figures 7.4 .1 .2 through 


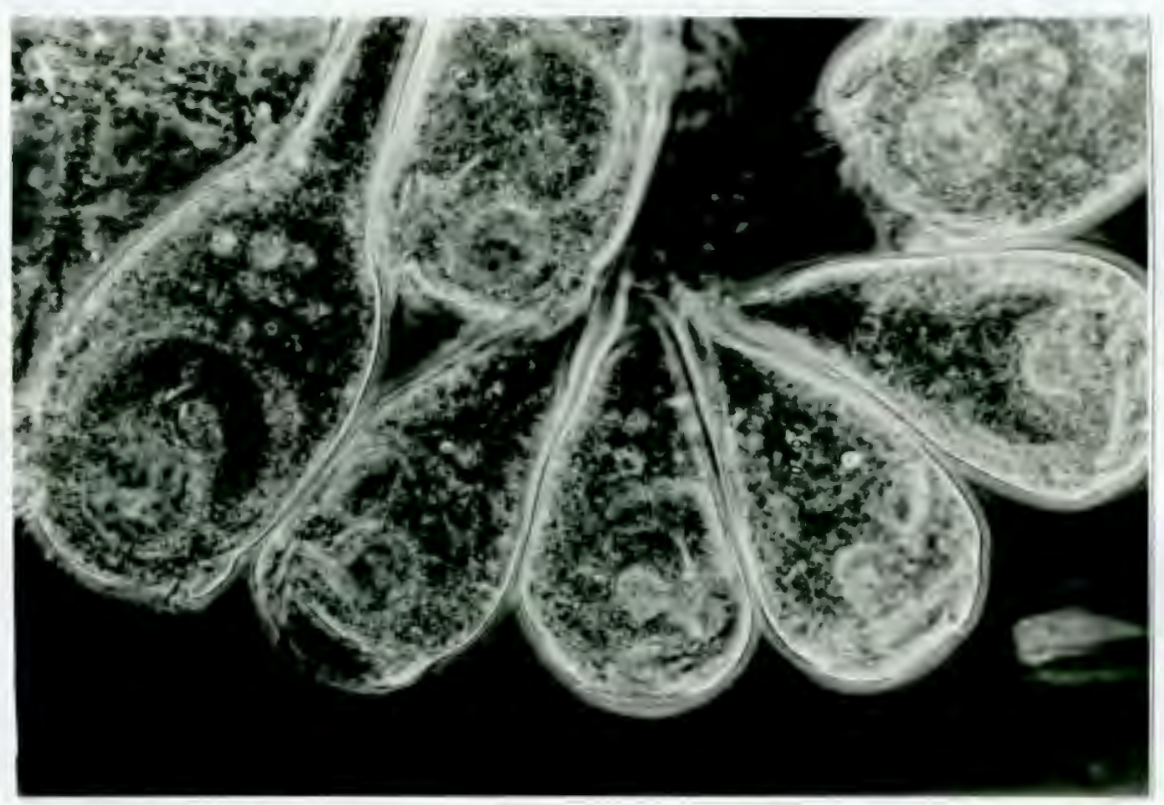

Figure 7.4.1.1 Photomicrograph of protozoa in a raw aerated wastewater $(160 x)$ 


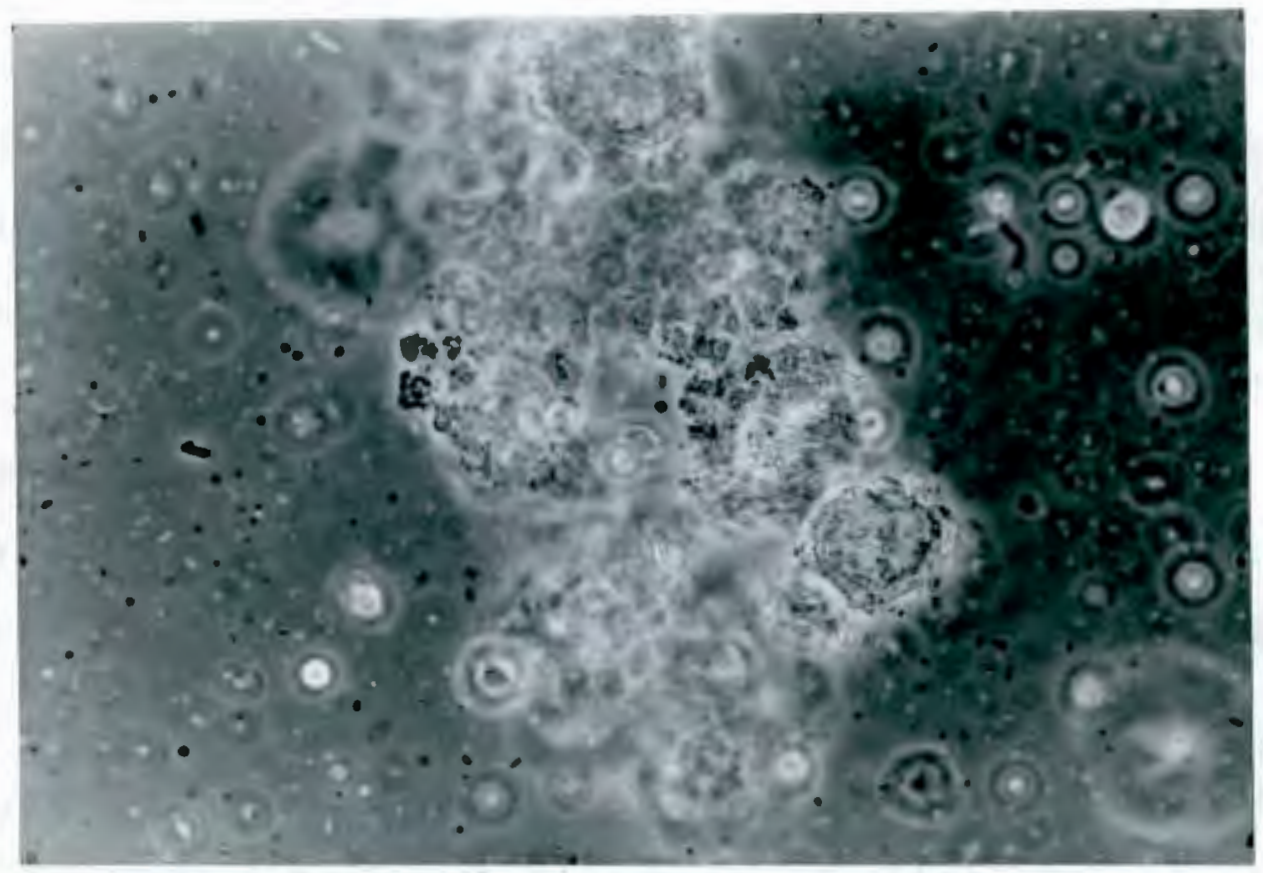

Figure 7.4.1.2 Photomicrograph of filamentous floc (bacteria) in the activated sludge $(160 x)$ 
7.4.1.5. The relative increase in the numbers of bacteria is a positive sign that acclimation of the system was occurring.

Rotifers started to appear after the third week of operation. The reappearance and increase of the rotifers was an additional indication of the acclimation of the AS to the industrial refinery wastewater. The MLVSS concentration also showed an increase from $1,580 \mathrm{mg} / \mathrm{L}$ to $2,040 \mathrm{mg} / \mathrm{L}$ in the period between week 2 and week 3 . A photomicrograph of a rotifer in the activated sludge is shown in Figure 7.4.1.6.

Acclimation of the AS biomass was reached approximately at the end of the fourth week. This was confirmed by both a relative increase in the bacteria, as well as a leveling off in the MLVSS concentration. Since the bacteria are the species responsible for the metabolism and removal of the dissolved organics, a biomass with a high relative concentration of bacteria is necessary for dissolved organics removal. A photomicrograph of the dispersed bacteria observed at the end of the fourth week is shown in Figure 7.4.1.7.

A summary of the changes in the population of the microorganisms is illustrated in Figure 7.4.1.8. The microorganism population in the AS did not change substantially after the acclimation period which occurred approximately 31 days from the start-up of the AS reactor. 


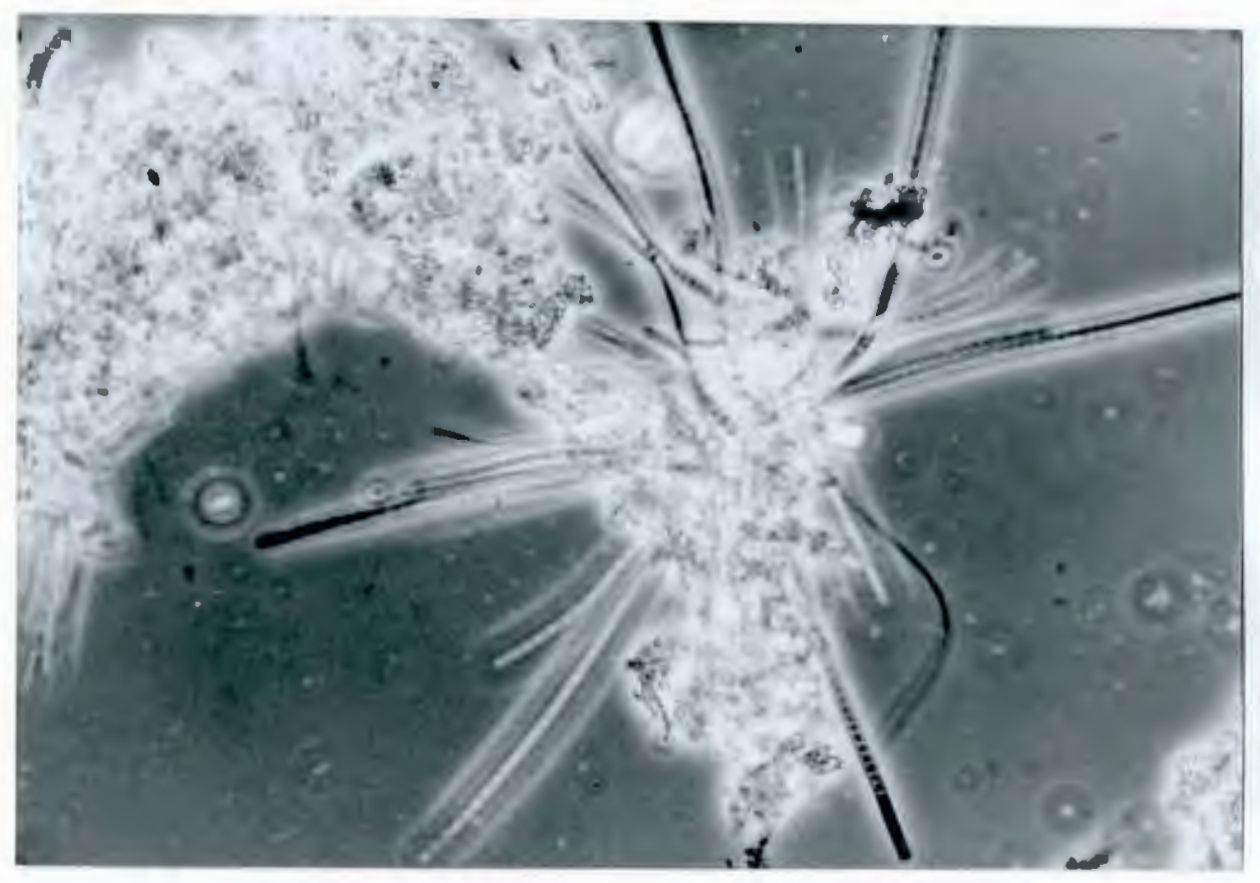
Figure 7.4.1.3 Photomicrograph of filamentous microorganisms (bacteria) in the activated siudge $(160 \mathrm{X})$




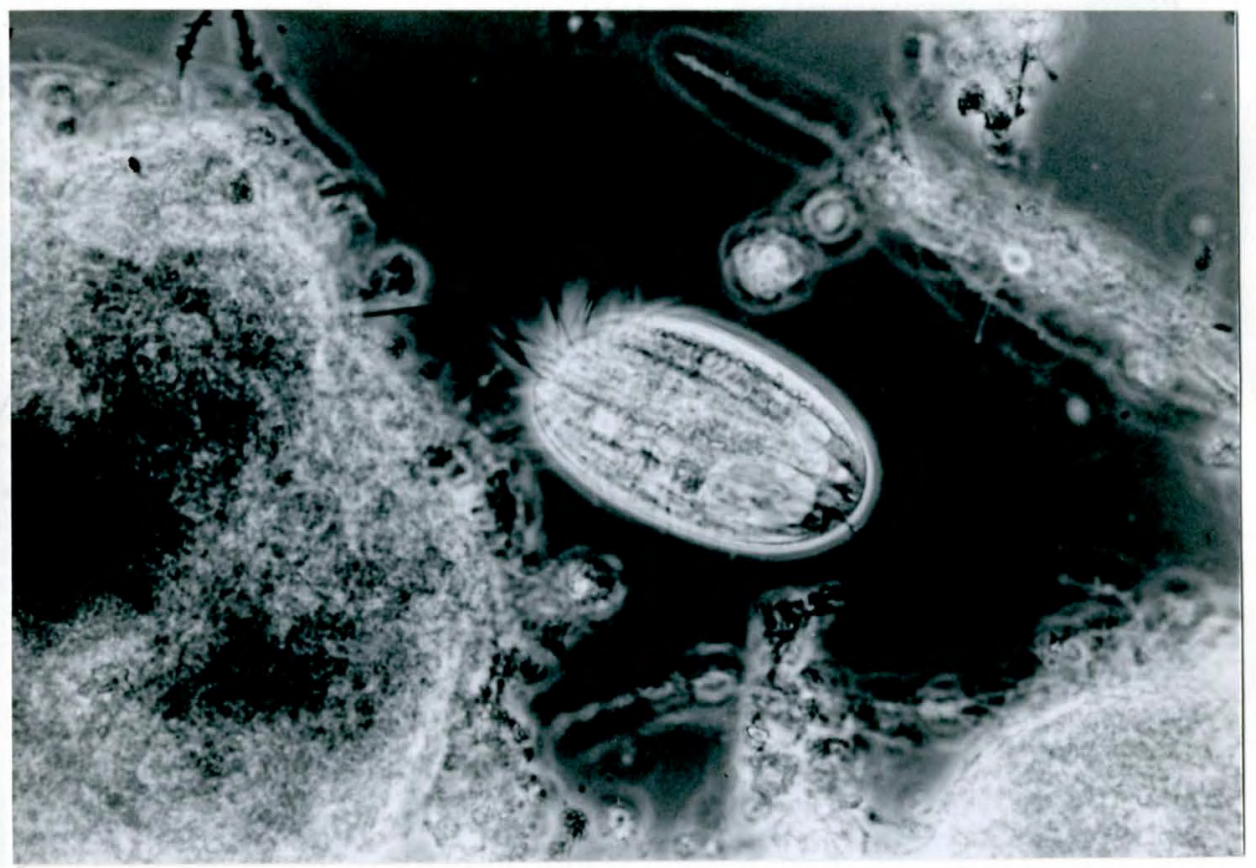

Figure 7.4.1.4 Photomicrograph of a ciliate microorganism in the activated sludge $(160 x)$ 


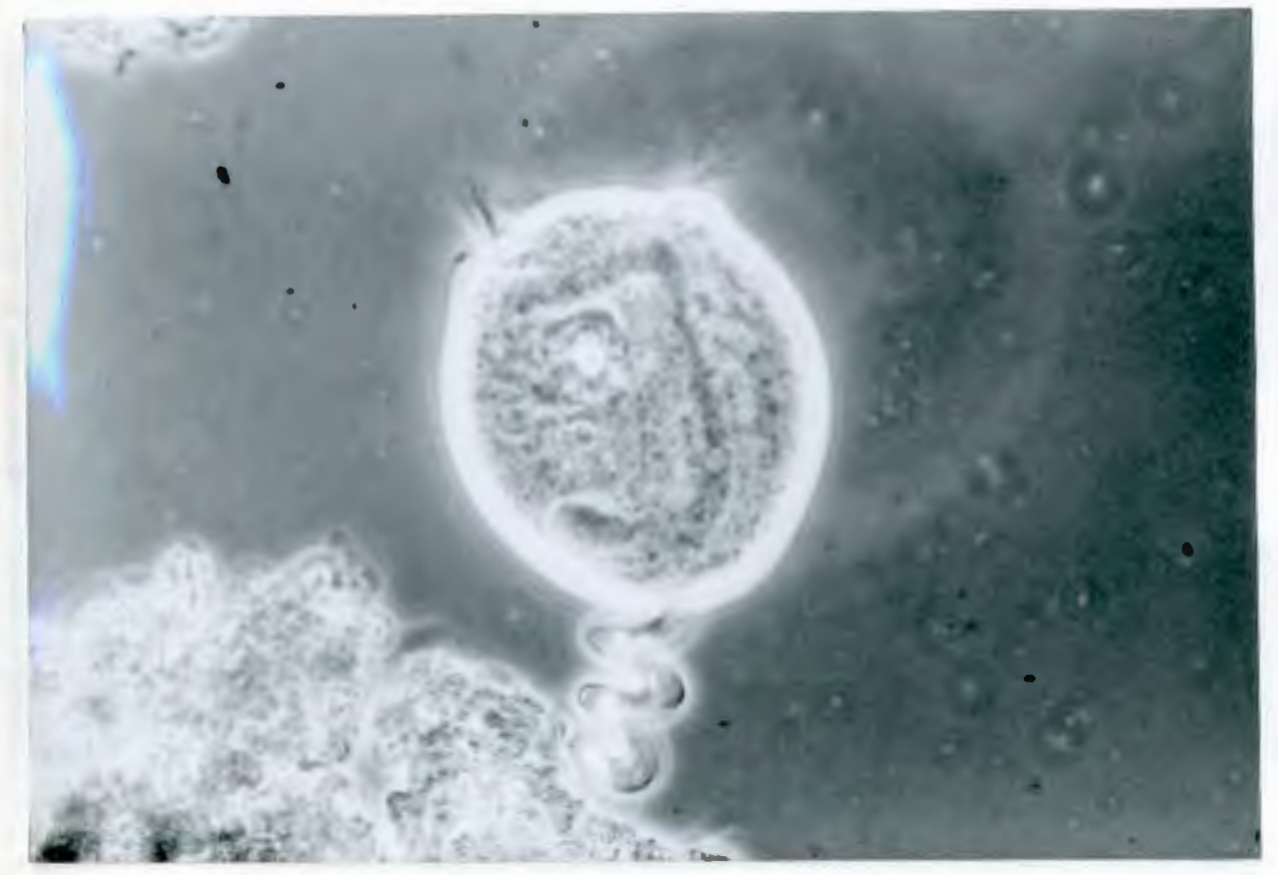

Figure 7.4.1.5 Photomicrograph of a ciliate in the activated sludge (160x) 


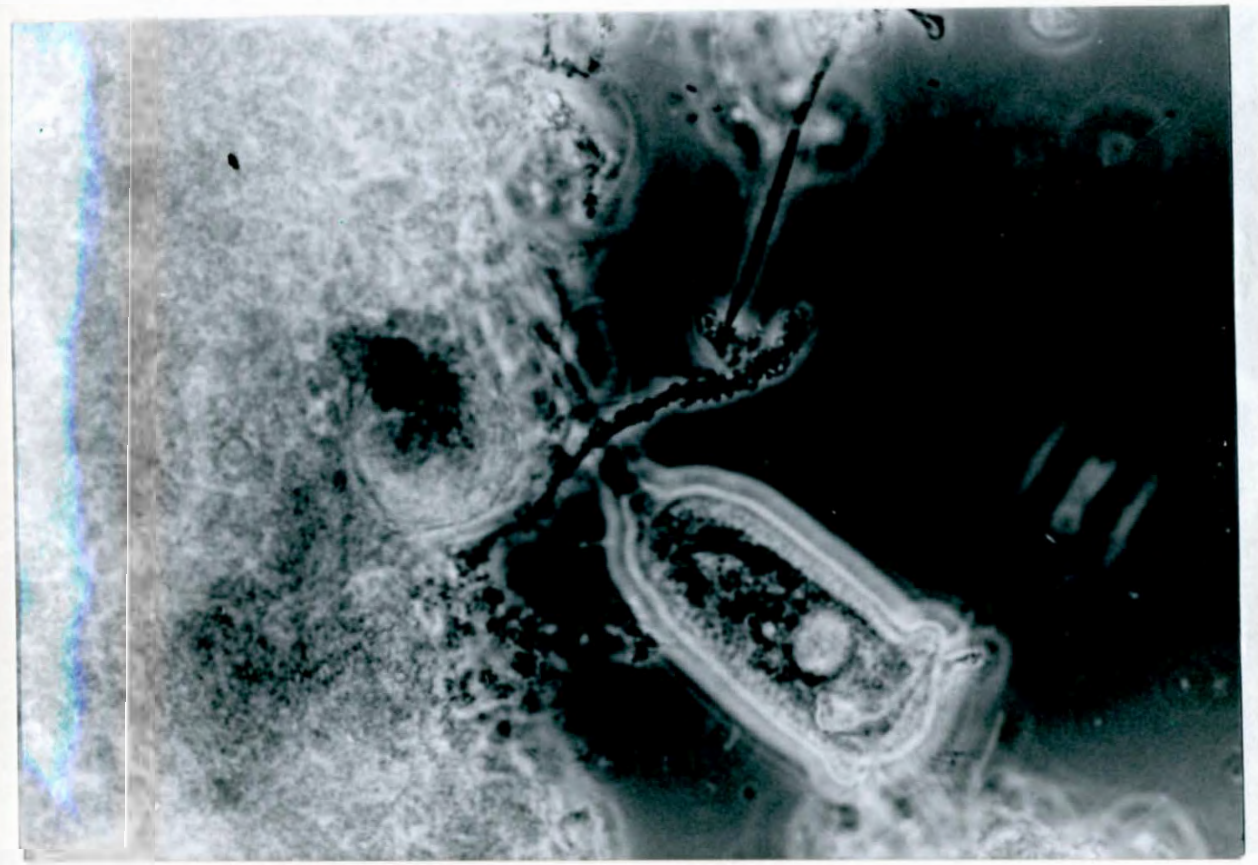

Figure 7.4.1.6 Photomicrograph of a rotifier in the activated sludge (160X) 


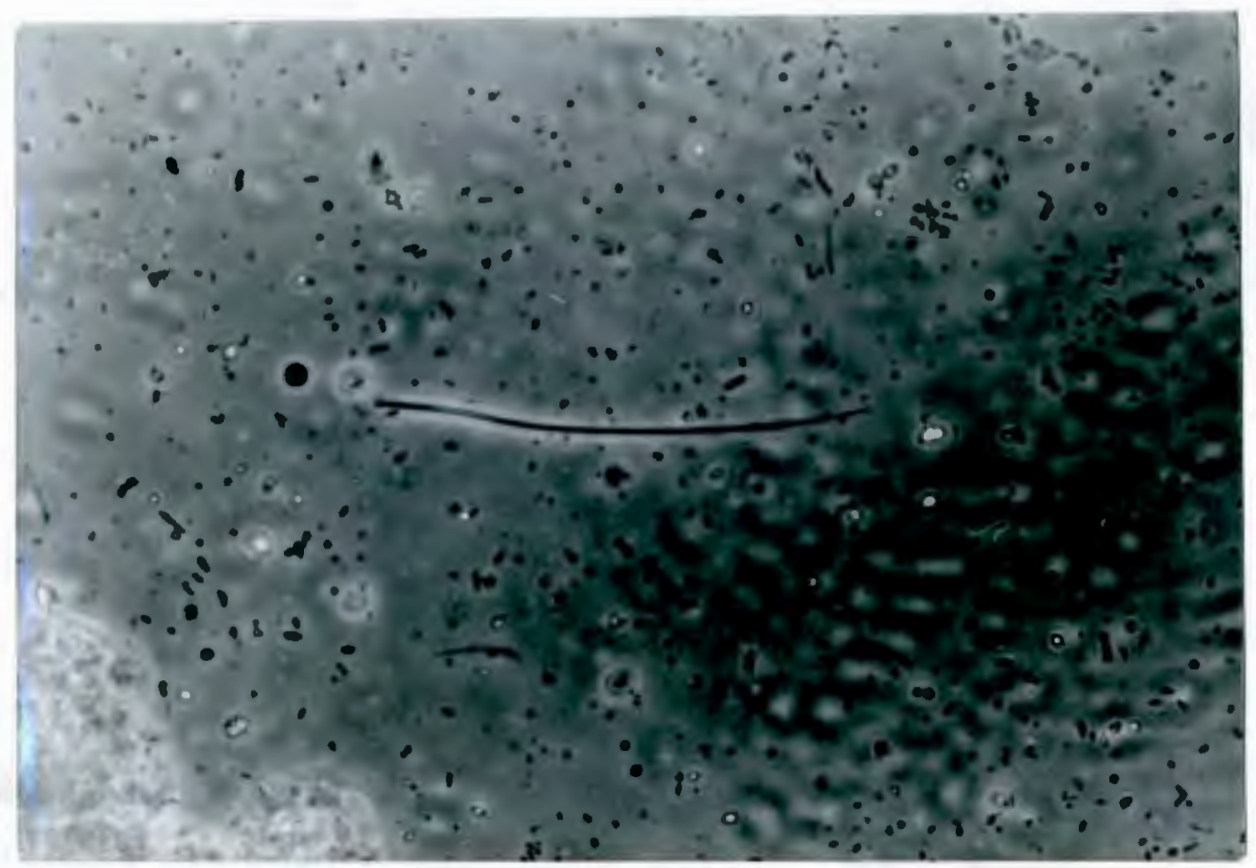

Figure 7.4.1.7 Photomicrograph of dispersed bacteria in the activated sludge $(160 x)$ 


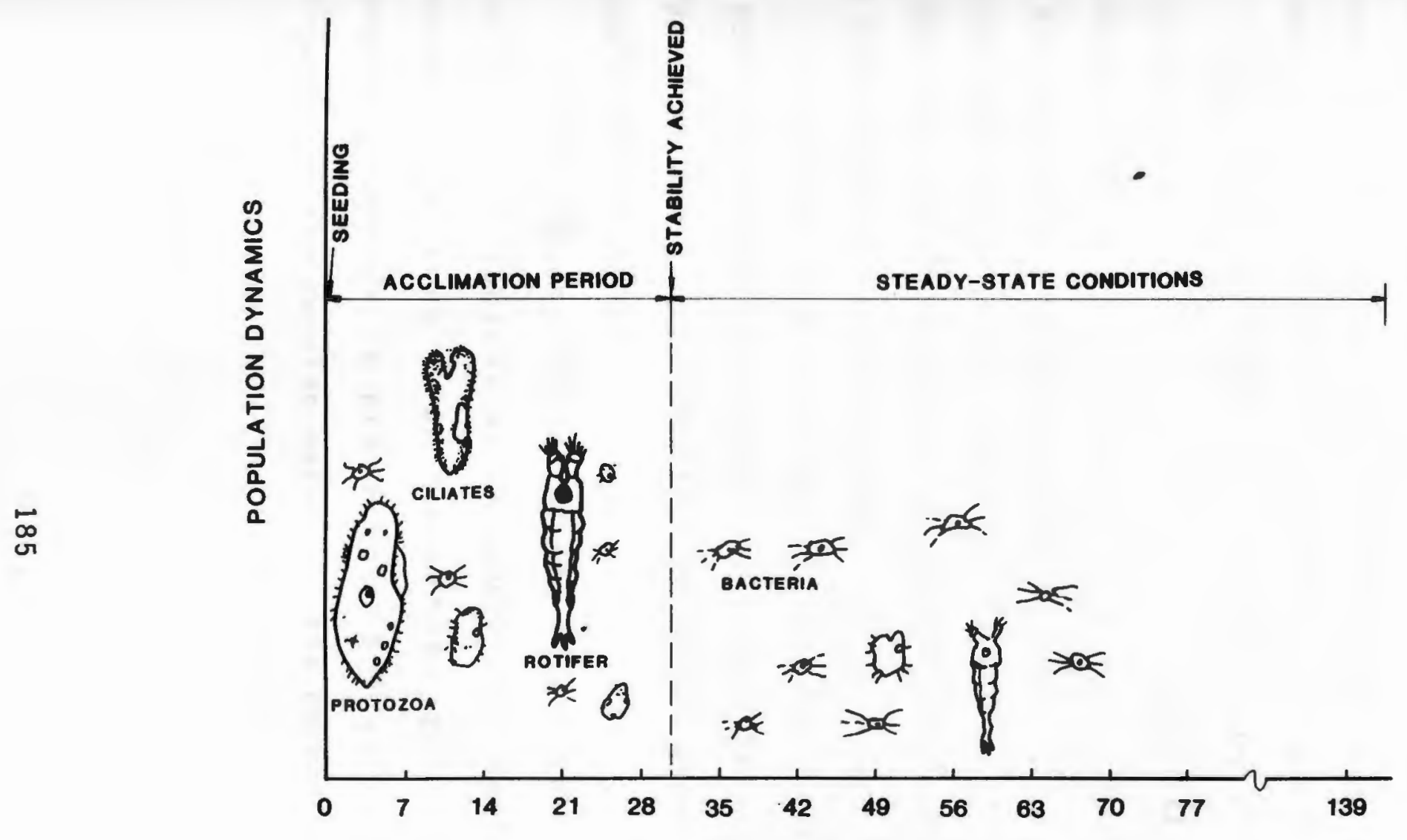

DAYS FROM STARTUP

Figure 7.4.1.8 Changing Microorganism Population in the
Aeration Tank 
7.4.2 Scanning Electron Microscopic Analysis When PAC has been added to the AS, an additional dissolved organic removal mechanism, adsorption, occurs in conjunction with biological oxidation. Not only does the PAC adsorb dissolved organics, but the high surface area of the carbon is an ideal site for fixed film bacteria to adhere to.

Microscopic analysis using a light microscope is sufficient for observing the relative population dynamics which occur within the AS. However, to observe the interactions between bacteria and PAC, very high magnifications, on the order of $25,000 x$, are necessary. These magnifications are only possible through the use of a scanning electron microscope.

A series of PAC/AS samples were collected such that bacterial growth on the PAC could be observed at various operation times. Increases in bacterial growth on the PAC could then be noted.

A SEM photomicrograph of the virgin carbon was taken to provide a control which would show carbon surfaces which were free from bacterial growth. Such a photomicrograph is presented in Figure 7.4.2.1 and illustrates the angular nature of the carbon surface. 


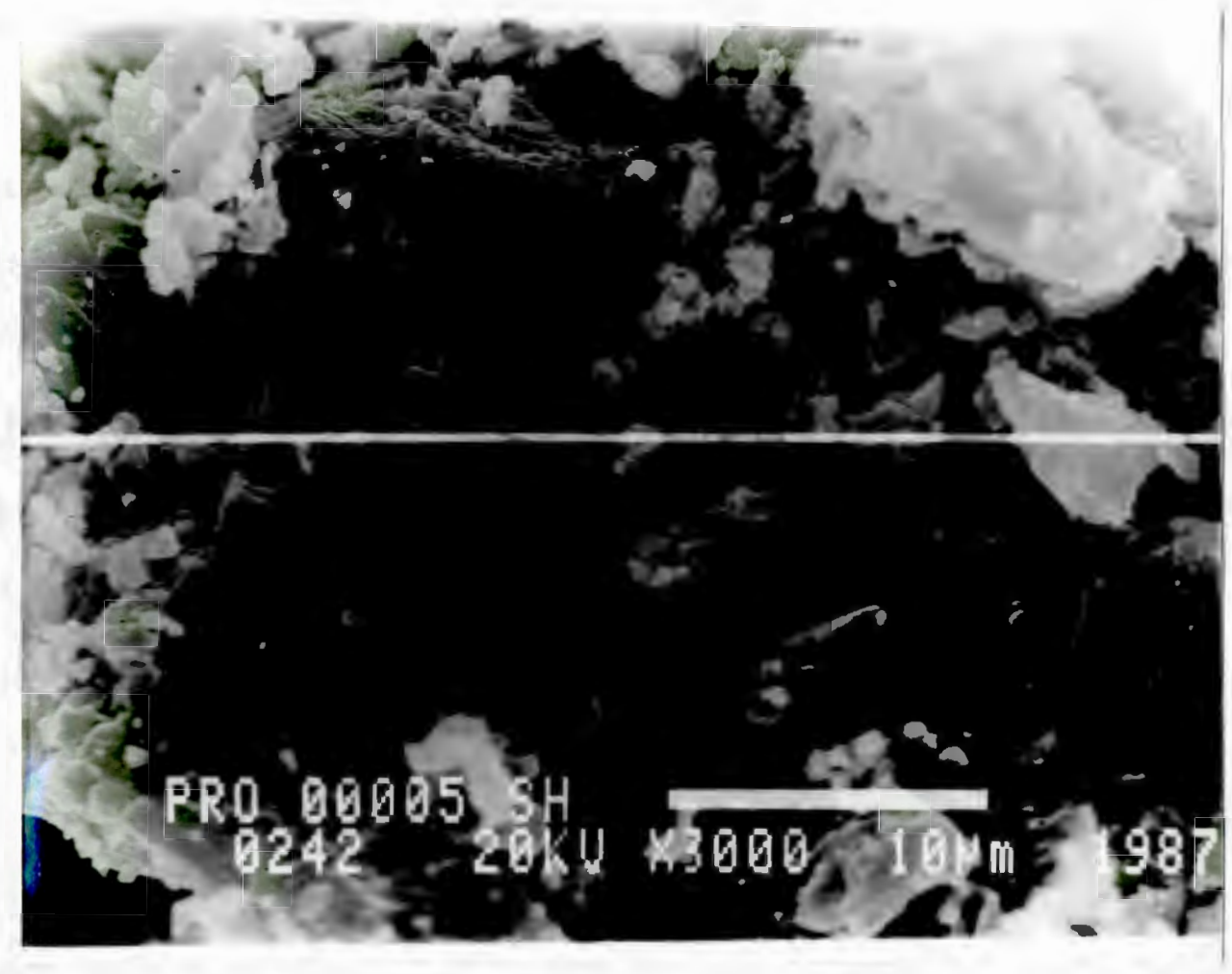

Figure 7.4.2.1 Scanning electron micrograph of the surface of virgin PAC particles without biological growth 
The first SEM observation of a sample of the PAC that was in contact with the AS was taken after 44 days of operation. At the time the PAC/AS sample was collected, the PAC concentration in the AS reactor was equal to 120 $\mathrm{mg} / \mathrm{L}$ and $\theta_{c}$ was equal to 3 days. Two photomicrographs were taken of the same PAC/AS sample using magnifications of 3,000 and $5,000 \mathrm{x}$. At a magnification of $3,000 \mathrm{x}$ (Figure 7.4.2.2) a variety of microorganisms are shown to be attached to the surfaces of the PAC. Also visible in this photomicrograph are PAC surfaces which are free of microorganisms. At the higher magnification of $5,000 \times$ (Figure 7.4.2.3) several rod shaped bacteria are shown which are attached to the PAC surfaces.

After a period of 56 days of operation another sample was withdrawn from the AS reactor and examined under the SEM. The operating conditions within the AS reactor when this sample was withdrawn were the same as the preceding sample except for a $\theta_{c}$ equal to 12 days. An overall photomicrograph of the PAC/AS at a magnification of 3,000 $X$ is reproduced in Figure 7.4.2.4. The PAC within this photomicrograph is completely covered with a layer of rodshaped bacteria. When the magnification was increased to $25,000 \times$ (Figure 7.4 .2 .5 ) the attachment of the individual rod-shaped bacteria to the PAC surface could be seen. It appears from this photomicrograph that not all of the PAC surface is covered with bacteria, which means that some of 


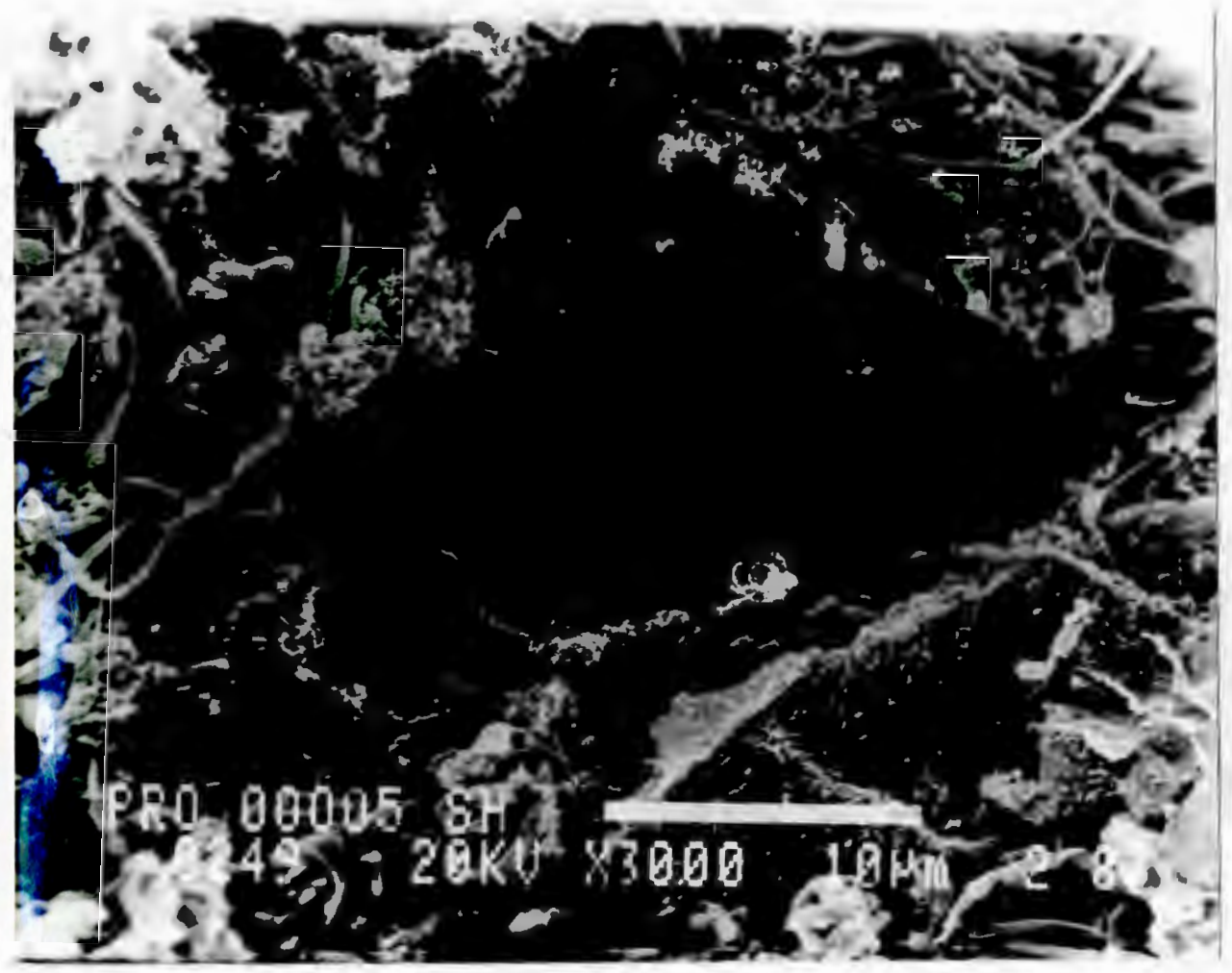

Figure 7.4.2.2 SCanning electron micrograph of PAC particles exposed to refinery industry wastewater for 44 days (rod-shaped bacteria were attached, PAC dosage $120 \mathrm{mg} / 1$, sludge age 3 days). 


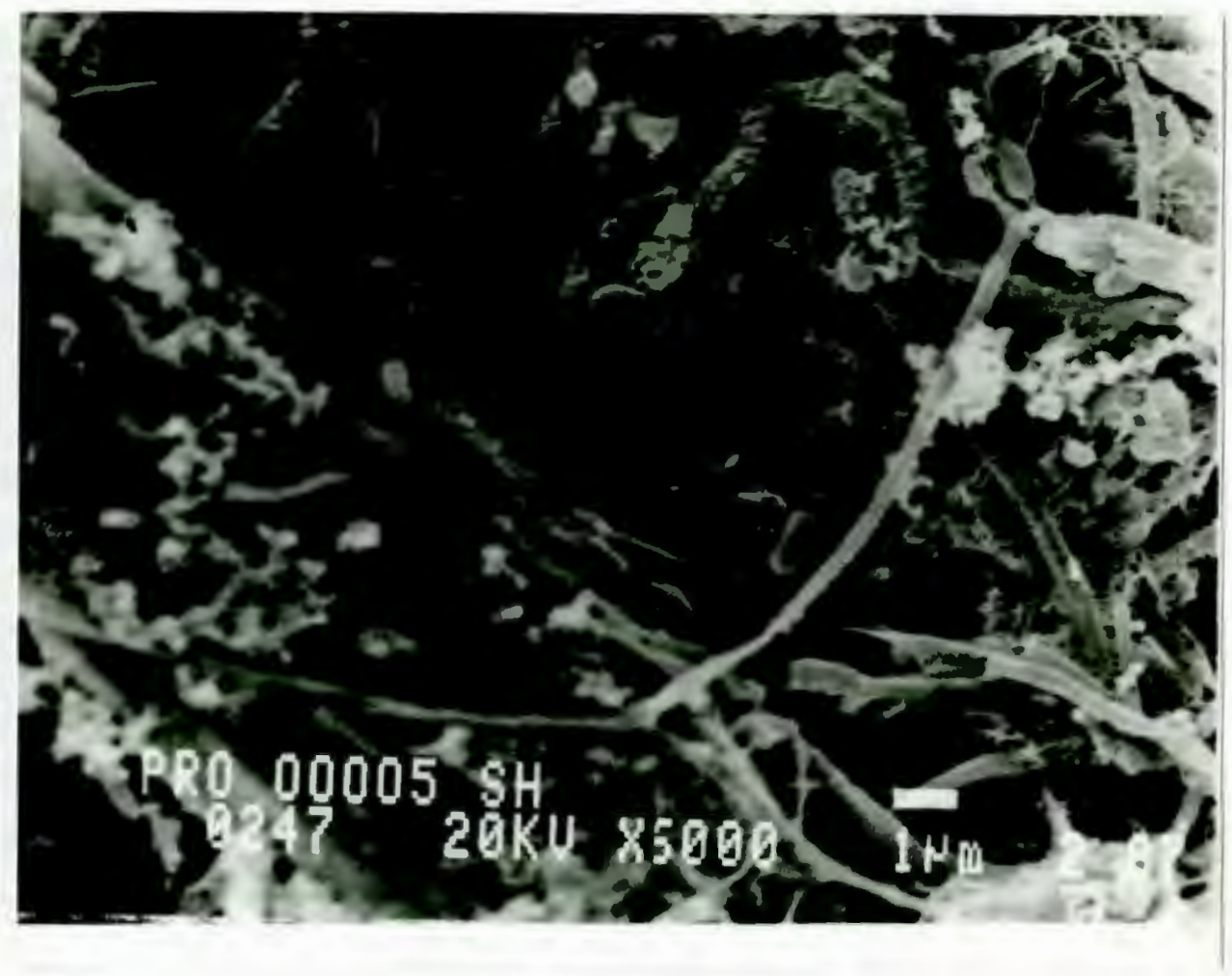

Figure 7.4.2.3 Scanning electron micrograph of PAC particles exposed to refinery industry wastewater for 44 days (rod-shaped bacteria are present in the wastewater, PAC dosage $120 \mathrm{mg} / 1$; sludge age 3 days). 


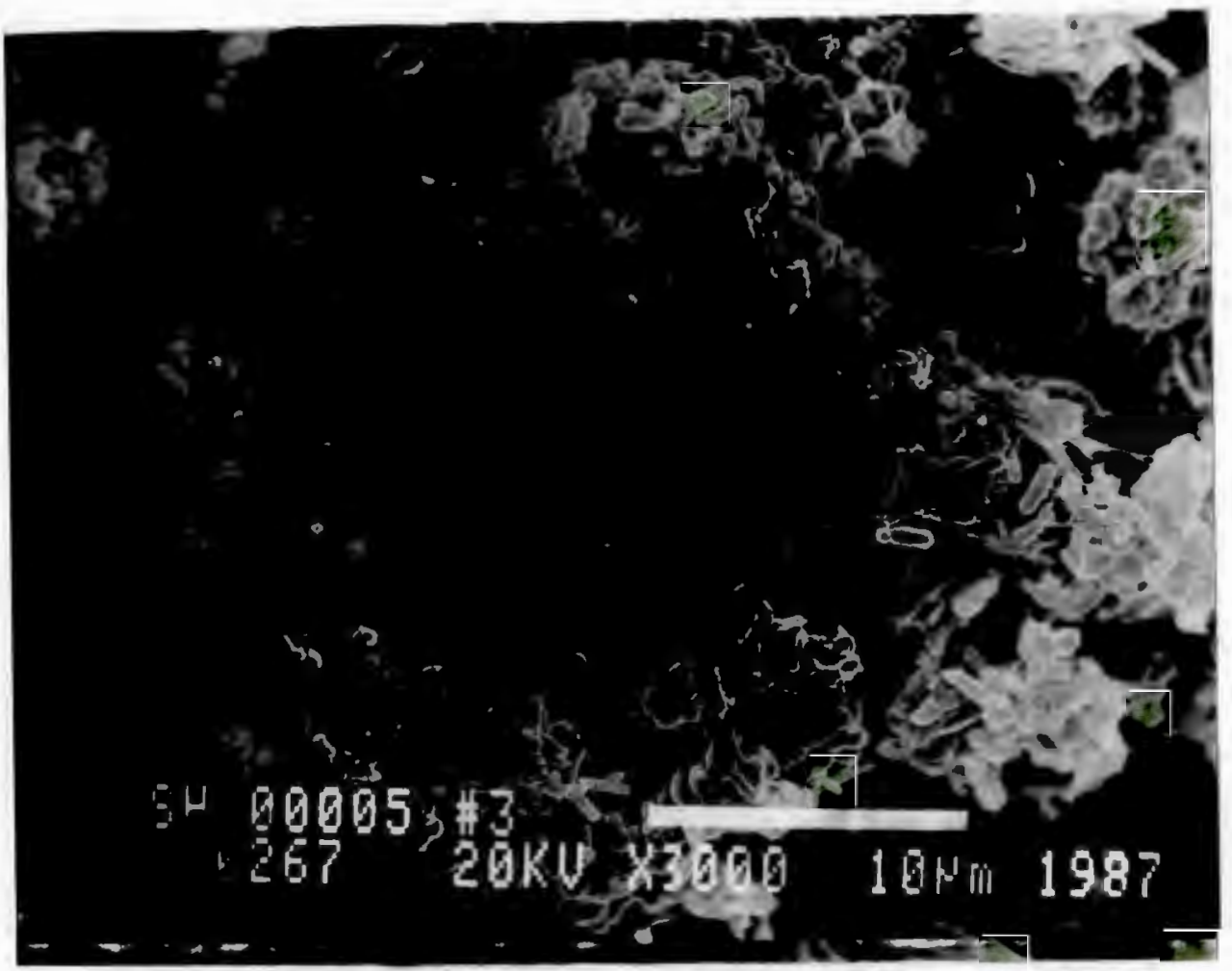

Figure 7.4.2.4 Scanning electron micrograph of PAC particles exposed to refinery industry wastewater for 56 days in a complete mixed reactor, (rod-shaped bacteria are growing on the PAC particles, PAC dosage $120 \mathrm{mg} / 1$; sludge age 12 days). 


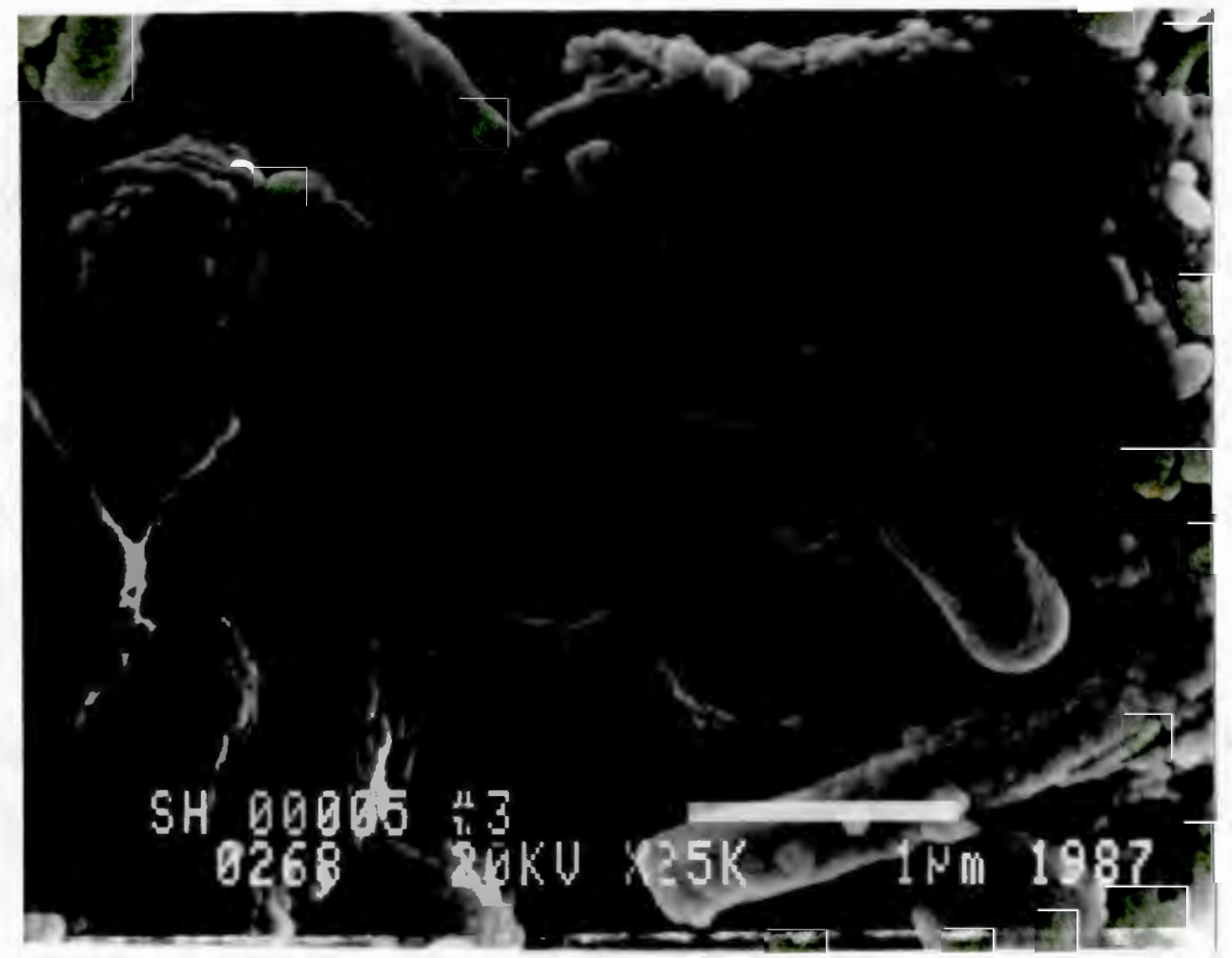

Figure 7.4.2.5 Scanning electron micrograph of PAC particles exposed to refinery industry wastewater for 56 days in complete mixed reactor, with $120 \mathrm{mg} / \mathrm{L}$ of carbon, (rodshaped bacteria are growing on PAC particles). 
the PAC surfaces were available for adsorption.

7.5 Experiment 3: Air Stripping Process

Within the conventional AS treatment process several dissolved organic removal mechanisms operate. The two major removal mechanisms are biological oxidation and air stripping. Air stripping can occur as dissolved organics are transferred from the liquid phase to the vapor phase during the aeration process. Experiment 3 was conducted in order to measure the potential air stripping of the following six compounds: benzene, chloroform, ethylbenzene, toluene, m-xylene and $0-x y l e n e$. Each of these compounds is categorized as a volatile organic compound by the US EPA.

Three separate air flow rates were studied: 300 , 400 , and $500 \mathrm{~m} 1 / \mathrm{min} / \mathrm{L}$. Each of these flow rates corresponded to the typical pilot plant air flow rates that were utilized during this study to maintain the dissolved oxygen concentration within the optimal range of 5 to $6 \mathrm{mg} / \mathrm{L}$.

A wide range of concentrations for each of the six organic compounds was studied: benzene 360-1,903 ug/L, chloroform 1,673-2,383 ug/L, ethylbenzene 20-340 ug/L, toluene 100-1,433 ug/L, m-xylene 40-740 ug/L, and $0-x y l e n e$ 65-670 ug/L. The results of these experiments are 
presented in Tables 7.5.1 to 7.5.3. With the exception of the concentration of the chloroform effluent at a flow rate of $400 \mathrm{ml} / \mathrm{min} / \mathrm{L}$ of $50 \mathrm{ug} / \mathrm{L}$, all other effluent concentrations were below $10 \mathrm{ug} / \mathrm{L}$ which was the detection limit for each of the volatile organics.

The air stripping results that were reported above are similar to a study by kincannon et al. (40) in which they observed that for an influent which consisted of a mixed industrial wastewater the volatile compounds which have Henry's Law Constants larger than $10^{3}$ atom-m $3 / m o l e$ are stripped from the AS reactor. Henry's Law Constants for benzene is $5.5 \times 10^{3}$ atom- $\mathrm{m}^{3} / \mathrm{mole}$, whereas the other volatile compounds have constants in the range of $10^{-3}$

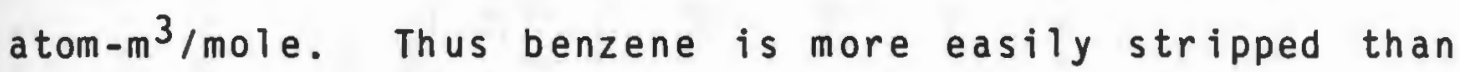
the other volatile compounds that were studied.

7.6 Experiment 4: PAC Without ACtivated Sludge

The purpose of experiment 4 was to quantify the removals of each of the compounds previously studied, with the exception of $\mathrm{BOO}_{5}$, which would result only from adsorption by the PAC present in the reactor. In order to accomplish this, the pilot plant was operated exactly as it was for the previous experiments except for the elimination of the biomass in the reactor. The PAC concentration in the reactor was maintained at $10 \mathrm{mg} / \mathrm{L}, 50$ 
Table 7.5.1 Percent Stripping of Volatile Compounds in Nonbiological System, Experiment 3, air flow rate $=300 \mathrm{ml} / \mathrm{min} / \mathrm{L}$.

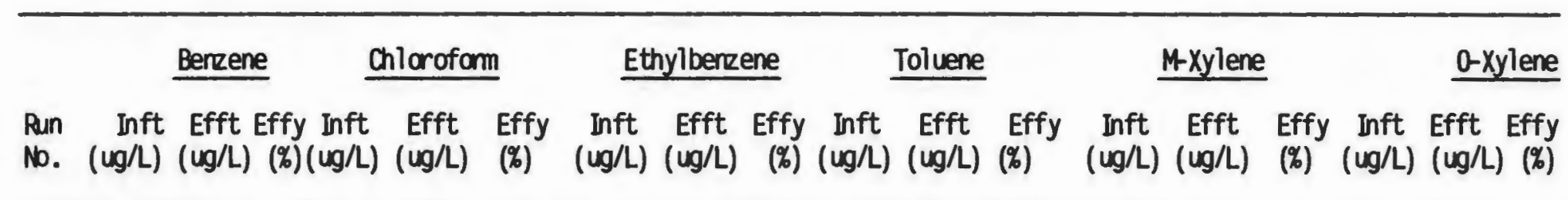

\begin{tabular}{|c|c|c|c|c|c|c|c|c|c|c|c|c|c|c|c|c|c|}
\hline 57 & 1,800 & ND & $>992,383$ & ND & $>99$ & 318 & ND & $>97$ & 1,350 & $N$ & $>99$ & 440 & N & $>98$ & 584 & ND & $>98$ \\
\hline 58 & 1,806 & ND & $>992,339$ & ND & $>99$ & 330 & ND & $>97$ & 1,383 & ND & $>99$ & 360 & ND & $>97$ & 270 & ND & $>96$ \\
\hline 59 & 1,903 & ND & 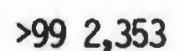 & ND & $>99$ & 318 & ND & $>97$ & 1,400 & ND & $>99$ & 460 & ND & $>98$ & 670 & ND & $>99$ \\
\hline
\end{tabular}

$N D=$ None detectable, detectability $>10 \mathrm{ug} / \mathrm{L}$ 
Table 7.5.2 Percent Stripping of Volatile Compounds in Norbiological System, Experiment 3, air flow rate $=400 \mathrm{ml} / \mathrm{min} / \mathrm{L}$.

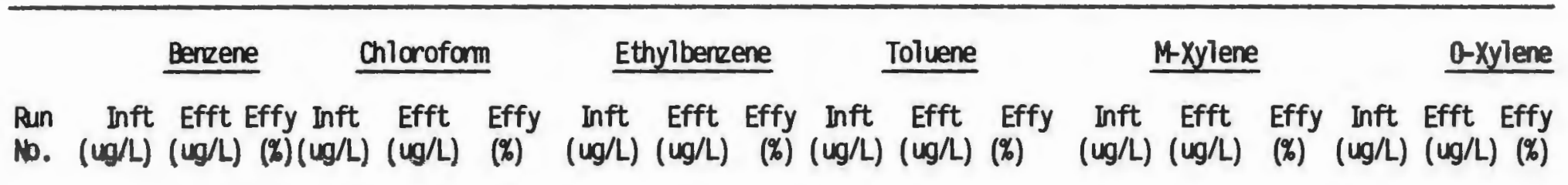

占

\begin{tabular}{|c|c|c|c|c|c|c|c|c|c|c|c|c|c|c|c|c|c|}
\hline 60 & 1,790 & N & $>992,295$ & ND & 299 & 340 & ND & $>97$ & 1,433 & N & $>99$ & 530 & ND & $>98$ & 390 & ND & $>97$ \\
\hline 61 & 1,774 & ND & $>992,299$ & ND & $>99$ & 340 & D & $>97$ & 1,383 & ND & 297 & 700 & D & $>97$ & 740 & ND & $>97$ \\
\hline & 10 & ND & $>99 \quad 2,341$ & 50 & 98 & 20 & ND & $>50$ & 100 & ND & $>90$ & 70 & ND & $>86$ & 80 & N & 8 \\
\hline
\end{tabular}

$N D=$ None detectable, detectability $>10 \mathrm{ug} / \mathrm{L}$ 
Table 7.5.3 Percent Stripping of Vol atile Compounds in Nonbiological System, Experiment 3, when air flow rate $500 \mathrm{ml} / \mathrm{min} / \mathrm{L}$.

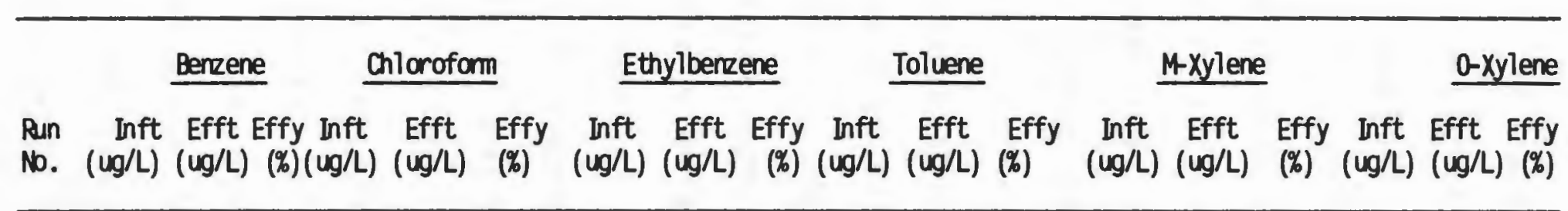

\begin{tabular}{|c|c|c|c|c|c|c|c|c|c|c|c|c|c|c|c|c|}
\hline 63 & 340 & N & $>97 \quad 1,784$ & N & $>99$ & 180 & ND & $>94$ & 160 & ND & $>94$ & 60 & ND & $>83$ & 80 & ND \\
\hline 64 & 360 & ND & $>97 \quad 1,673$ & ND & $>99$ & ND & ND & ND & 182 & ND & $>95$ & 90 & $N$ & $>89$ & 150 & ND \\
\hline 65 & 360 & $\mathbf{N}$ & $>97 \quad 1,781$ & $\mathrm{ND}$ & $>99$ & 20 & ND & $>50$ & 200 & ND & $>95$ & 40 & $N$ & $>75$ & 65 & ND \\
\hline
\end{tabular}

ND $=$ None detectable, detectability $>10 \mathrm{ug} / \mathrm{L}$ 
$\mathrm{mg} / \mathrm{L}$ and $120 \mathrm{mg} / \mathrm{L}$ during each individual phase of the investigation. At each PAC concentration, the influent and effluent concentrations of all previously studied compounds were measured.

As the concentration of the PAC in the reactor was increased from $10 \mathrm{mg} / \mathrm{L}$ to $50 \mathrm{mg} / \mathrm{L}$ and finally to $120 \mathrm{mg} / \mathrm{L}$ the COD removals increased from approximately $56 \%$ up to a maximum of $83 \%$ (Tables $7.6 .1-3$ and Figure 7.6.1). However, when these COD removals are compared to the removals which resulted from the combination of $A S$ and PAC, which averaged about $87 \%$ and were similar at all PAC dosages, it could be noted that from a PAC concentration of $10 \mathrm{mg} / \mathrm{L}$ up to a PAC concentration of $120 \mathrm{mg} / \mathrm{L}$ the percentage removal improvement was constant.

TOC removals were measured and the results are presented in tabular form in Tables 7.6.1-3 and in graphical form in Figure 7.6.2. The curve which depicts the influence of various dosages of PAC on the TOC removals showed a dependence on the PAC reactor concentration as the TOC removals increased from $43 \%$ at a PAC concentration of $10 \mathrm{mg} / \mathrm{L}$ up to $76 \%$ for a PAC concentration of $120 \mathrm{mg} / \mathrm{L}$. A similar but less pronounced trend was evident for the PAC/AS system in that removals increased from $82 \%$ with no additions of PAC up to $90 \%$ at the highest PAC reactor concentration. 
Table 7.6.1 COD and TOC Removal Efficiencies in Experiment 4, When $P A C=10 \mathrm{mg} / \mathrm{L}$.

\begin{tabular}{lcrrrrrr}
$\begin{array}{l}\text { Date } \\
1986\end{array}$ & $\begin{array}{c}\text { Day } \\
\text { No. }\end{array}$ & $\begin{array}{c}\text { Inft } \\
(\mathrm{mg} / \mathrm{L})\end{array}$ & $\begin{array}{c}\text { COD } \\
\text { Efft } \\
(\mathrm{mg} / \mathrm{L})\end{array}$ & $\begin{array}{l}\text { Effy } \\
(\%)\end{array}$ & $\begin{array}{r}\text { Inft } \\
(\mathrm{mg} / \mathrm{L})\end{array}$ & $\begin{array}{r}\text { TOC } \\
\text { Efft } \\
(\mathrm{mg} / \mathrm{L})\end{array}$ & $\begin{array}{l}\text { Effy } \\
(\%)\end{array}$ \\
\hline $12 / 20$ & 66 & 419 & 134 & 68 & 25 & 13 & 48 \\
$12 / 21$ & 67 & 1,000 & 518 & 48 & 336 & 157 & 53 \\
$12 / 22$ & 68 & 549 & 257 & 53 & 33 & 33 & 28
\end{tabular}

Table 7.6.2 COD and TOC Removal Efficiencies in Experiment 4, When $P A C=50 \mathrm{mg} / \mathrm{L}$.

\begin{tabular}{lccccccc}
$\begin{array}{l}\text { Date } \\
1986\end{array}$ & $\begin{array}{c}\text { Day } \\
\text { No. }\end{array}$ & $\begin{array}{c}\text { Inft } \\
(\mathrm{mg} / \mathrm{L})\end{array}$ & $\begin{array}{c}\text { COD } \\
\text { Efft } \\
(\mathrm{mg} / \mathrm{L})\end{array}$ & $\begin{array}{l}\text { Effy } \\
(\%)\end{array}$ & $\begin{array}{c}\text { Inft } \\
(\mathrm{mg} / \mathrm{L})\end{array}$ & $\begin{array}{c}\text { TOC } \\
\text { Efft } \\
(\mathrm{mg} / \mathrm{L})\end{array}$ & $\begin{array}{c}\text { Effy } \\
(\%)\end{array}$ \\
\hline $12 / 23$ & 69 & 584 & 104 & 82 & 56 & 14 & 75 \\
$12 / 24$ & 70 & 588 & 100 & 83 & 39 & 12 & 69 \\
$12 / 25$ & 71 & 592 & 77 & 87 & 48 & 15 & 69
\end{tabular}

Table 7.6.3 COD and TOC Removal Efficiencies in Experiment 4, When $P A C=120 \mathrm{mg} / \mathrm{L}$.

\begin{tabular}{llrrrrrr}
$\begin{array}{l}\text { Date } \\
1986\end{array}$ & $\begin{array}{c}\text { Day } \\
\text { No. }\end{array}$ & $\begin{array}{c}\text { Inft } \\
(\mathrm{mg} / \mathrm{L})\end{array}$ & $\begin{array}{c}\text { COD } \\
\text { Efft } \\
(\mathrm{mg} / \mathrm{L})\end{array}$ & $\begin{array}{l}\text { Effy } \\
(\%)\end{array}$ & $\begin{array}{r}\text { TOC } \\
\text { Inft } \\
(\mathrm{mg} / \mathrm{L})\end{array}$ & $\begin{array}{r}\text { Efft } \\
(\mathrm{mg} / \mathrm{L})\end{array}$ & $\begin{array}{c}\text { Effy } \\
(\%)\end{array}$ \\
\hline $12 / 26$ & 72 & 552 & 100 & 82 & 37 & 9 & 76 \\
$12 / 27$ & 73 & 552 & 104 & 81 & 28 & 17 & 40 \\
$12 / 28$ & 74 & 524 & 80 & 85 & 25 & 22 & 12 \\
\hline
\end{tabular}




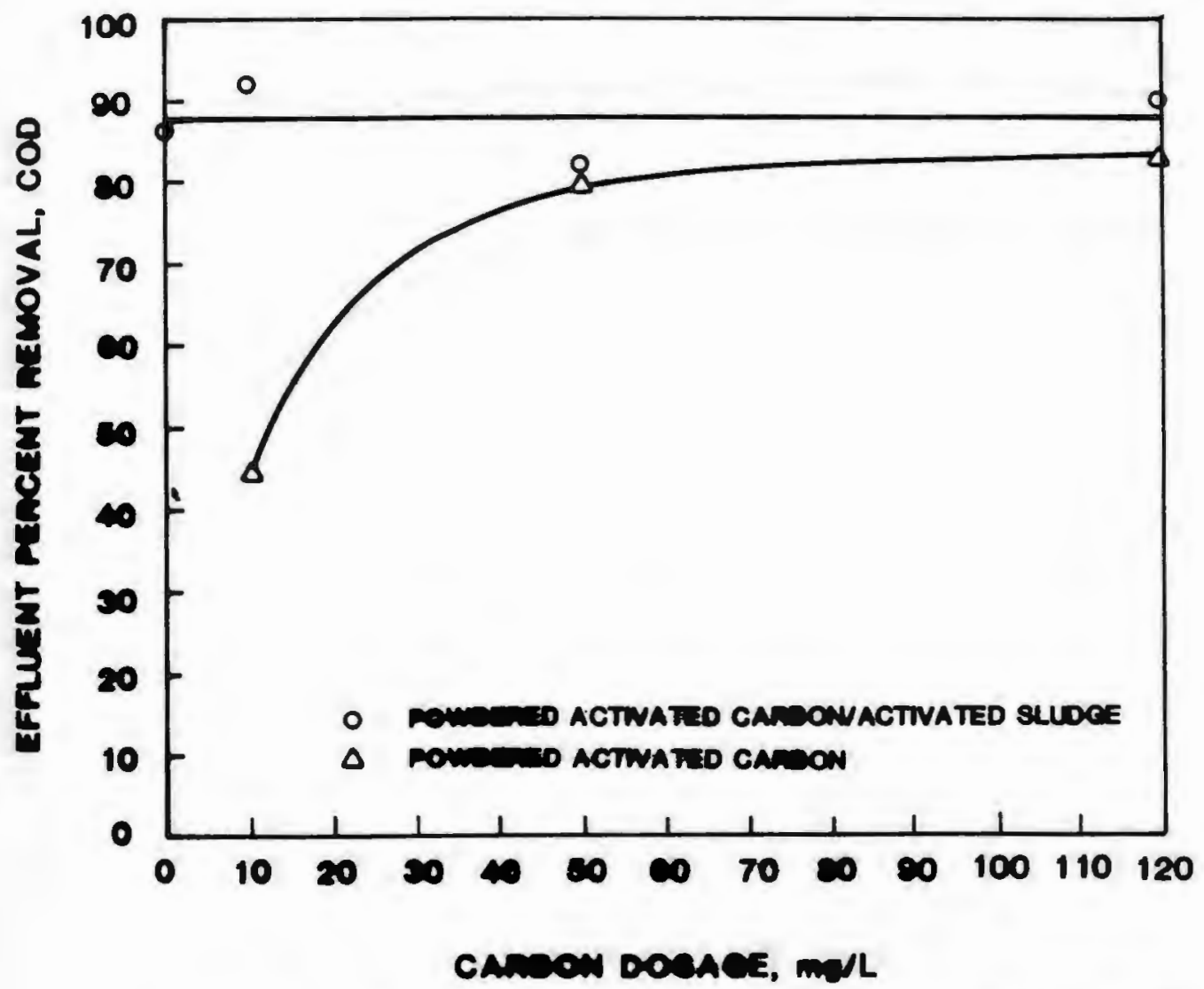

Figure 7.6.1 A Comparison of COD Removal by PAC and PAC/AS 


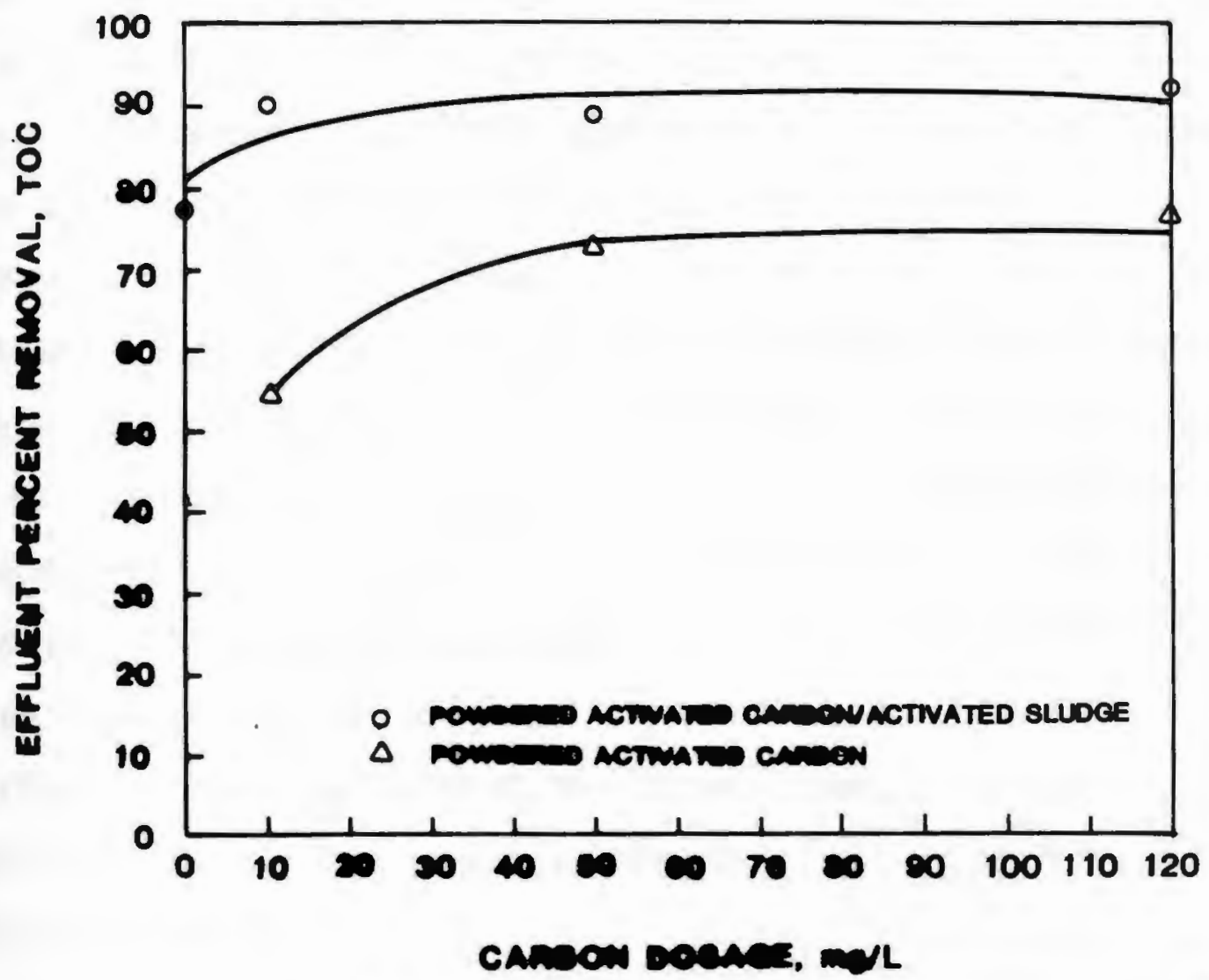

Figure 7.6.2 A Comparison of TOC Removal by PAC and PAC/AS 
Removal of the remaining priority organic pollutants (2,4 dimethylphenol, fluorene, napthalene and pyrene) by adsorption was studied and the results are presented in Tables 7.6.4-6 and Figures 7.6.3-6. The influent concentrations of 2,4 dimethylphenol, fluorene, naphthalene and pyrene ranged from $1,040-9,707 \mathrm{ug} / \mathrm{L}, 80-533 \mathrm{ug} / \mathrm{L}, 100-$ $4,093 \mathrm{ug} / \mathrm{L}$, and 13-113 ug/L, respectively. Due to the extreme variability of the influent organic concentration there did not appear to be a correlation between the PAC concentration in the reactor and the effluent concentration. The compound 2,4 dimethylphenol effluent concentration appeared to be relatively insensitive to wide swings in the influent concentration, whereas the effluent concentrations of the other compounds appeared to somewhat track the highest variations in the influent concentrations.

The adsorption of the priority organic compounds that were previously studied was investigated. The percentage removals of each of the volatile compounds (benzene, chloroform, ethylbenzene, toluene, m-xylene and o-xylene) during this experiment ranged from a 10 of $67 \%$ for ethyibenzene to greater than $90 \%$ for each of the other compounds (Tables 7.6.7-9). This was due to the fact that the volatile compounds are easily air stripped under the operating conditions which exist in the reactor as shown in section 7.5 . 
Table 7.6.4 Priority Organic Pollutants' Removal Efficiencies in Experiment 4, when PAC $=10 \mathrm{mg} / \mathrm{L}$.

\begin{tabular}{|c|c|c|c|c|c|c|c|c|c|c|c|c|c|}
\hline $\begin{array}{l}\text { Date } \\
1986\end{array}$ & $\begin{array}{l}\text { Day } \\
\text { No. }\end{array}$ & 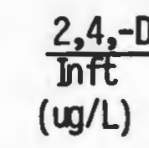 & $\begin{array}{c}\text { imethylp } \\
\text { Efft } \\
(\omega g / L)\end{array}$ & $\frac{\text { Enol }}{\text { Effy }}$ & $\underset{(\mathrm{Inft} / \mathrm{L})}{\mathrm{I}}$ & $\begin{array}{c}\text { Fluorene } \\
\text { Efft } \\
(u g / L)\end{array}$ & $\begin{array}{l}\text { Effy } \\
(\%)\end{array}$ & $\begin{array}{l}\operatorname{Inft}_{(\mathrm{g} / \mathrm{L})}^{\mathrm{Na}} \\
\end{array}$ & $\begin{array}{l}\text { phthalen } \\
\text { Efft } \\
(\lg / \mathrm{L})\end{array}$ & $\begin{array}{l}\text { Effy } \\
(\%)\end{array}$ & $\begin{array}{l}\text { Inft } \\
(\mathrm{Lg} / \mathrm{L})\end{array}$ & $\begin{array}{l}\frac{\text { Pyrene }}{\text { Efft }} \\
(\mathrm{g} / \mathrm{L})\end{array}$ & $\begin{array}{r}\text { Effy } \\
(\%)\end{array}$ \\
\hline $\begin{array}{l}12 / 20 \\
12 / 21 \\
12 / 22\end{array}$ & $\begin{array}{l}66 \\
67 \\
68\end{array}$ & $\begin{array}{l}1,806 \\
9,707 \\
1,040\end{array}$ & $\begin{array}{r}93 \\
180 \\
47\end{array}$ & $\begin{array}{l}95 \\
98 \\
95\end{array}$ & $\begin{array}{r}100 \\
80 \\
533\end{array}$ & $\begin{array}{l}\mathrm{ND} \\
20 \\
13\end{array}$ & $\begin{array}{r}>90 \\
75 \\
98\end{array}$ & $\begin{array}{l}1,200 \\
4,093 \\
1,867\end{array}$ & $\begin{array}{r}70 \\
373 \\
233\end{array}$ & $\begin{array}{l}94 \\
91 \\
88\end{array}$ & $\begin{array}{r}\text { MD } \\
\text { ND } \\
113\end{array}$ & $\begin{array}{l}\mathrm{ND} \\
\mathrm{ND} \\
20\end{array}$ & $\begin{array}{l}\text { ND } \\
\text { ND } \\
82\end{array}$ \\
\hline
\end{tabular}

$\mathrm{ND}=$ None detectable, detectability $>10 \mathrm{ug} / \mathrm{L}$

Table 7.6.5 Priority Organic Pollutants' Removal Efficiencies in Experiment 4, when PAC $=50 \mathrm{mg} / \mathrm{L}$.

\begin{tabular}{|c|c|c|c|c|c|c|c|c|c|c|c|c|c|}
\hline \multirow{2}{*}{$\begin{array}{l}\text { Date } \\
1986\end{array}$} & \multirow{2}{*}{$\begin{array}{l}\text { Day } \\
\text { No. }\end{array}$} & \multicolumn{3}{|c|}{ 2,4,-Dimethylphenol } & \multicolumn{3}{|c|}{ Fluorene } & \multicolumn{3}{|c|}{ Naphthalene } & \multicolumn{3}{|c|}{ Pyrene } \\
\hline & & $\begin{array}{l}\text { Inft } \\
(\mathrm{ug} / \mathrm{L})\end{array}$ & $\begin{array}{l}\text { Efft } \\
(\mathrm{Lg} / \mathrm{L})\end{array}$ & $\begin{array}{l}\text { Effy } \\
(\%)\end{array}$ & $\begin{array}{c}\text { Inft } \\
(\mathrm{ug} / \mathrm{L})\end{array}$ & $\begin{array}{c}\text { Efft } \\
(\mathrm{ug} / \mathrm{L})\end{array}$ & $\begin{array}{l}\text { Effy } \\
(\%)\end{array}$ & $\begin{array}{l}\text { Inft } \\
(\mathrm{Lg} / \mathrm{L})\end{array}$ & $\begin{array}{l}\text { Efft } \\
(\mathrm{ug} / \mathrm{L})\end{array}$ & $\begin{array}{r}\text { Effy } \\
(\%)\end{array}$ & $\begin{array}{l}\text { Inft } \\
\text { (ug/L) }\end{array}$ & $\begin{array}{l}\text { Efft } \\
(u g / L)\end{array}$ & $\begin{array}{r}\text { Effy } \\
\text { (\%) }\end{array}$ \\
\hline $12 / 23$ & 69 & 4,924 & 253 & 95 & 111 & 3 & 97 & 1,267 & 25 & 98 & 13 & ND & $>23$ \\
\hline $12 / 24$ & 70 & 4,920 & 153 & 97 & 187 & 13 & 93 & 533 & 87 & 84 & ND & ND & $\overline{N D}$ \\
\hline $12 / 25$ & 71 & 4,506 & 33 & 99 & 220 & 49 & 78 & 573 & 120 & 77 & ND & ND & ND \\
\hline
\end{tabular}

ND $=$ None detectable, detectability $>10 \mathrm{ug} / \mathrm{L}$ 
Table 7.6.6 Priority Organic Pollutants' Removal Efficiencies in Experiment 4, when PAC $=120 \mathrm{mg} / \mathrm{L}$.

\begin{tabular}{|c|c|c|c|c|c|c|c|c|c|c|c|c|c|}
\hline \multirow{2}{*}{$\begin{array}{l}\text { Date } \\
1986\end{array}$} & \multirow{2}{*}{$\begin{array}{l}\text { Day } \\
\text { No. }\end{array}$} & \multicolumn{3}{|c|}{ 2,4,-Dimethylphenol } & \multicolumn{3}{|c|}{ Fluorene } & \multicolumn{3}{|c|}{ Naphthalene } & \multicolumn{3}{|c|}{ Pyrene } \\
\hline & & $\begin{array}{c}\text { Inft } \\
(\mathrm{g} / \mathrm{L})\end{array}$ & $\begin{array}{c}\text { Efft } \\
\text { (ug/L) }\end{array}$ & $\begin{array}{l}\text { Effy } \\
(\%)\end{array}$ & $\begin{array}{l}\text { Inft } \\
(\mathrm{ug} / \mathrm{L})\end{array}$ & $\begin{array}{c}\text { Efft } \\
\text { (ug/L) }\end{array}$ & $\begin{array}{l}\text { Effy } \\
\text { (\%) }\end{array}$ & $\begin{array}{l}\text { Inft } \\
(\mathrm{ug} / \mathrm{L})\end{array}$ & $\begin{array}{l}\text { Efft } \\
(\mathrm{ug} / \mathrm{L})\end{array}$ & $\begin{array}{l}\text { Effy } \\
(\%)\end{array}$ & $\begin{array}{l}\text { Inft } \\
\text { (ug/L) }\end{array}$ & $\begin{array}{l}\text { Efft } \\
(\mathrm{ug} / \mathrm{L})\end{array}$ & $\begin{array}{r}\text { Effy } \\
\text { (\%) }\end{array}$ \\
\hline $12 / 26$ & 72 & 7,440 & 13 & 99 & 187 & ND & $>95$ & 600 & 23 & 96 & $\mathbf{N D}$ & ND & ND \\
\hline $12 / 27$ & 73 & 4,936 & 15 & 99 & 132 & ND & $>92$ & 933 & 8 & 99 & ND & ND & ND \\
\hline $12 / 28$ & 74 & 4,930 & 27 & 99 & 107 & ND & $>91$ & 100 & 24 & 98 & ND & ND & ND \\
\hline
\end{tabular}

ND = None detectable, detectability $>10 \mathrm{ug} / \mathrm{L}$

Table 7.6.7 Volatile Compounds Ranoval Efficiencies in Experiment 4, when PAC $=10 \mathrm{mg} / \mathrm{L}$.

\begin{tabular}{|c|c|c|c|c|c|c|c|c|c|c|c|c|c|c|c|c|c|c|}
\hline \multirow[b]{2}{*}{$\begin{array}{l}\text { Date } \\
1986\end{array}$} & \multirow[b]{2}{*}{$\begin{array}{l}\text { Run } \\
\text { No. }\end{array}$} & \multirow{2}{*}{$\underset{(\operatorname{Inf} / L)}{\operatorname{Int}}$} & Berzene & \multicolumn{3}{|c|}{ Chlorofom } & \multicolumn{3}{|c|}{ Ethylberzene } & \multicolumn{3}{|c|}{ Toluene } & \multicolumn{3}{|c|}{ M-Xylene } & \multicolumn{3}{|c|}{ O-xylene } \\
\hline & & & $\begin{array}{l}\text { Efft E } \\
(u g / L)\end{array}$ & $\begin{array}{l}\text { Effy Inft } \\
(\%)(u g / L)\end{array}$ & $\begin{array}{l}\text { Efft } \\
(\mathrm{ug} / \mathrm{L})\end{array}$ & $\begin{array}{l}\text { Effy } \\
(\%)\end{array}$ & $\begin{array}{l}\text { Inft } \\
(\mathrm{ug} / L)\end{array}$ & $\begin{array}{c}\text { Efft } \\
(u g / L)\end{array}$ & $\begin{array}{r}\text { Effy } \\
(\%)\end{array}$ & $\begin{array}{l}\text { Inft } \\
\text { (ug/L) }\end{array}$ & $\begin{array}{c}\text { Efft } \\
\text { (ug/L) }\end{array}$ & $\begin{array}{l}\text { Effy } \\
(\%)\end{array}$ & $\begin{array}{l}\text { Inft } \\
(\mathrm{ug} / \mathrm{L})\end{array}$ & $\begin{array}{c}\text { Efft } \\
(u g / L)\end{array}$ & $\begin{array}{l}\text { Effy } \\
(\%)\end{array}$ & $\begin{array}{l}\text { Inft } \\
(\mathrm{ug} / \mathrm{L})\end{array}$ & $\begin{array}{l}\mathrm{Efft} \\
(\mathrm{ug} / \mathrm{L})\end{array}$ & $\begin{array}{l}\text { Effy } \\
\text { (\%) }\end{array}$ \\
\hline $\begin{array}{l}12 / 20 \\
12 / 21 \\
12 / 22\end{array}$ & $\begin{array}{l}66 \\
67 \\
68\end{array}$ & $\begin{array}{l}1,320 \\
1,383 \\
2,092\end{array}$ & $\begin{array}{l}\text { ND } \\
N D \\
\text { ND }\end{array}$ & $\begin{array}{l}>992,190 \\
>992,239 \\
>99 \\
2,468\end{array}$ & $\begin{array}{l}\text { ND } \\
\text { ND } \\
90\end{array}$ & $\begin{array}{r}>99 \\
>99 \\
96\end{array}$ & $\begin{array}{r}50 \\
60 \\
560\end{array}$ & $\begin{array}{l}\text { ND } \\
N D \\
N D\end{array}$ & $\begin{array}{l}>80 \\
>83 \\
>98\end{array}$ & $\begin{array}{r}700 \\
640 \\
3,067\end{array}$ & $\begin{array}{l}N D \\
N D \\
N D\end{array}$ & $\begin{array}{l}>99 \\
>98 \\
>99\end{array}$ & $\begin{array}{r}120 \\
180 \\
1,076\end{array}$ & $\begin{array}{l}N D \\
N D \\
N D\end{array}$ & $\begin{array}{l}>92 \\
>94 \\
>99\end{array}$ & $\begin{array}{l}240 \\
240 \\
800\end{array}$ & $\begin{array}{l}N D \\
N D \\
N D\end{array}$ & $\begin{array}{l}>96 \\
>96 \\
>99\end{array}$ \\
\hline
\end{tabular}

ND $=$ None detectable, detectability $>10 \mathrm{ug} / \mathrm{L}$ 


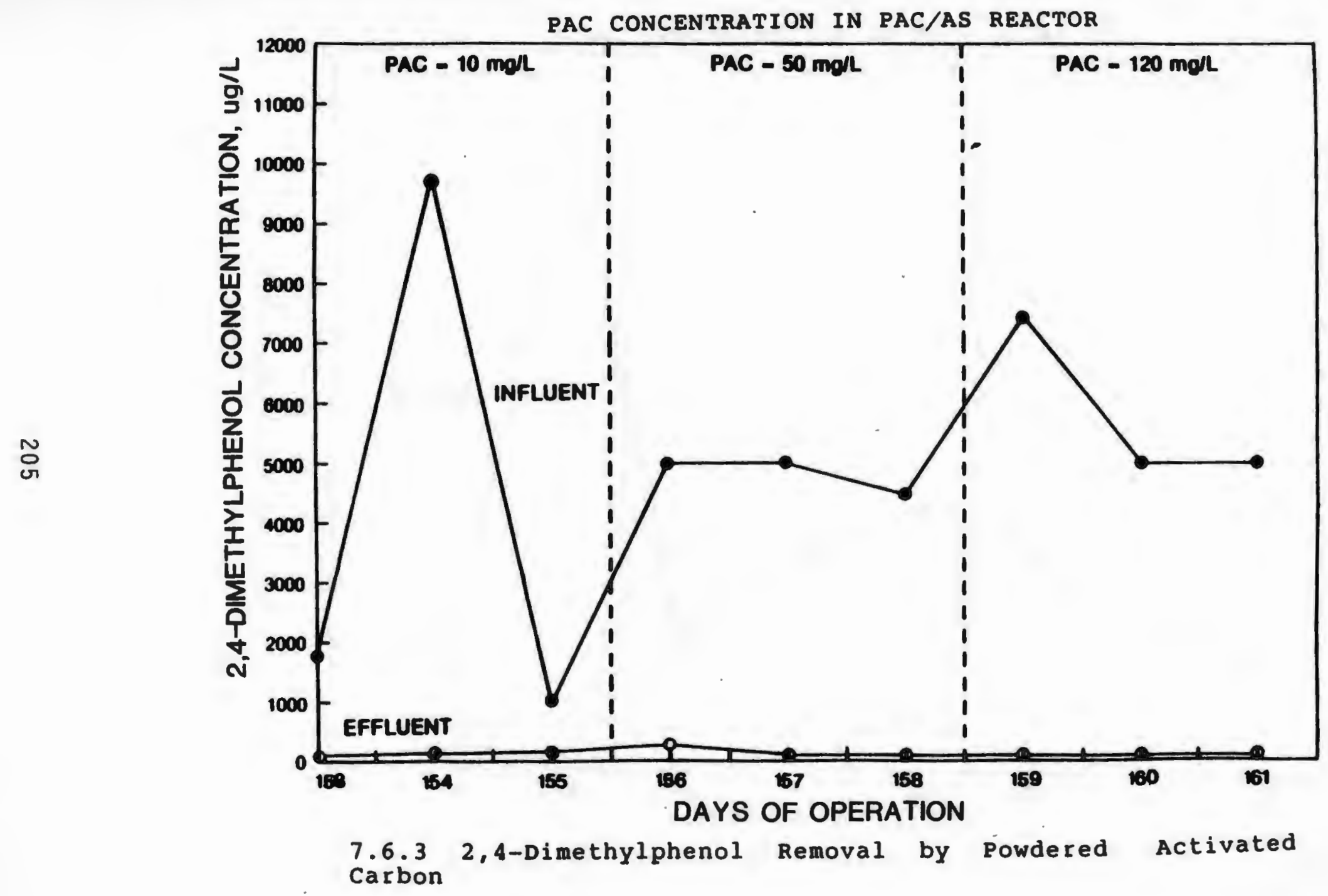




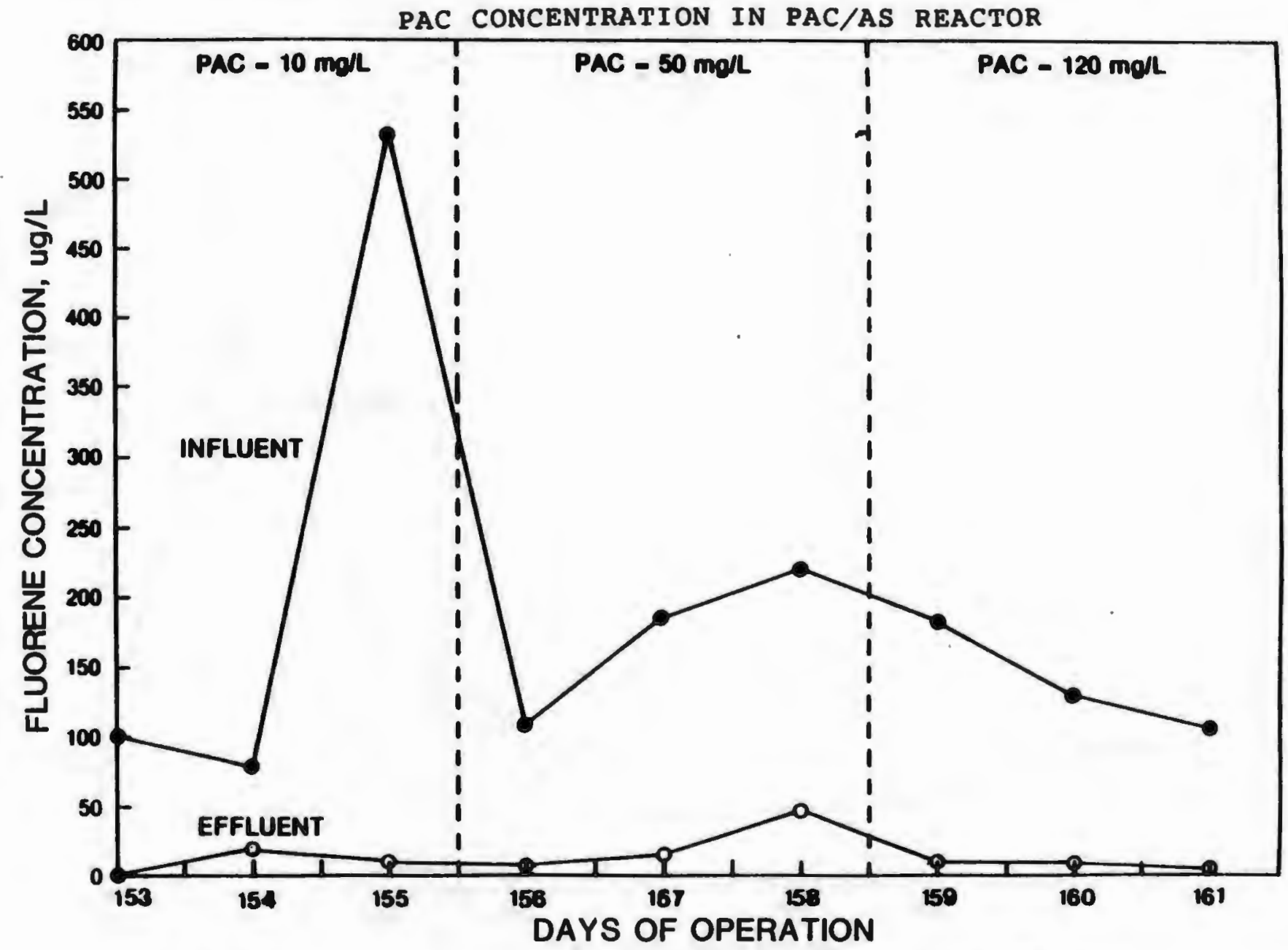

7.6.4 Fluorene Removal by Powdered Activated Carbon 


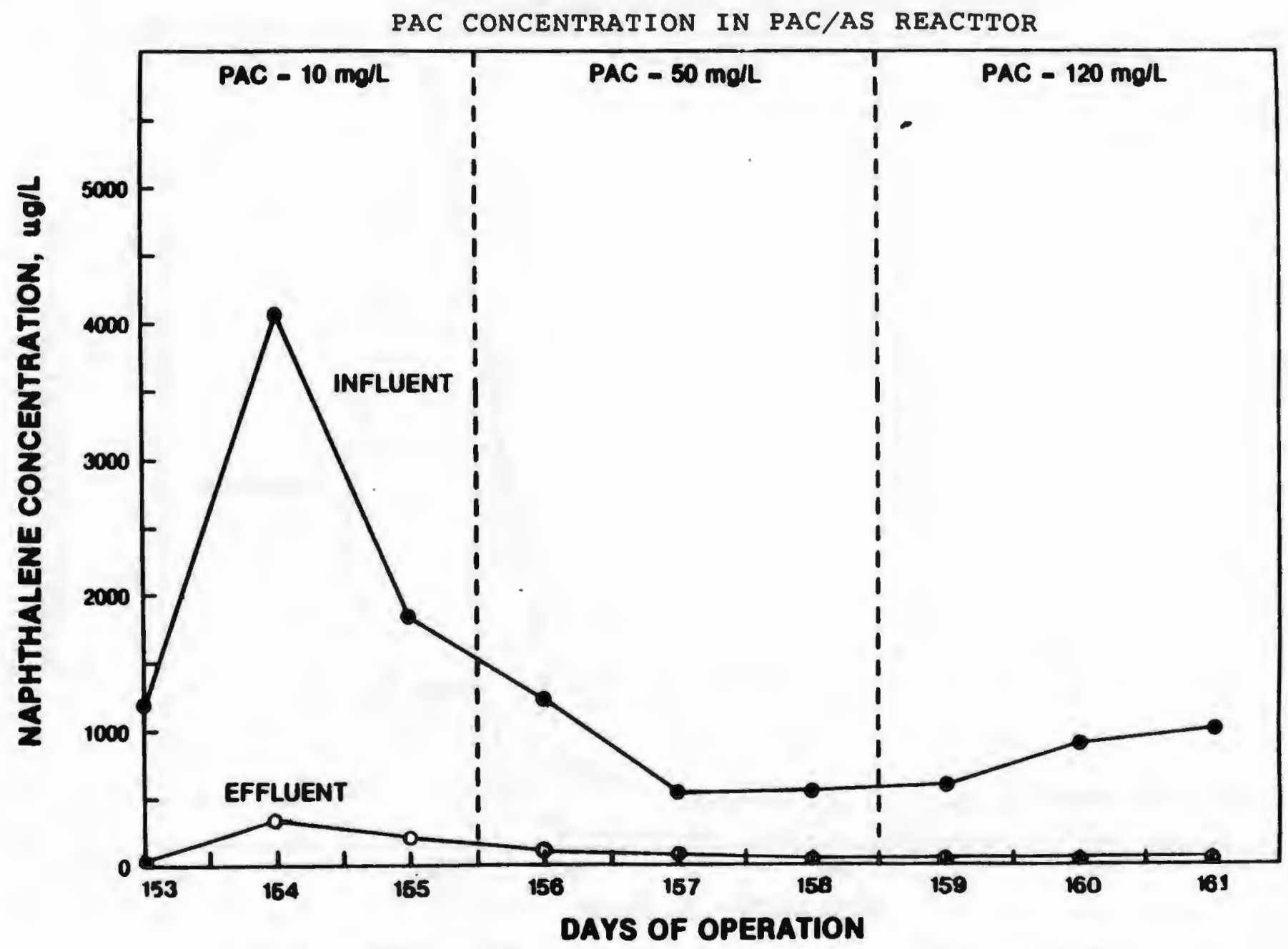

7.6.5 Naphthalene Removal by Powdered Activated Carbon 


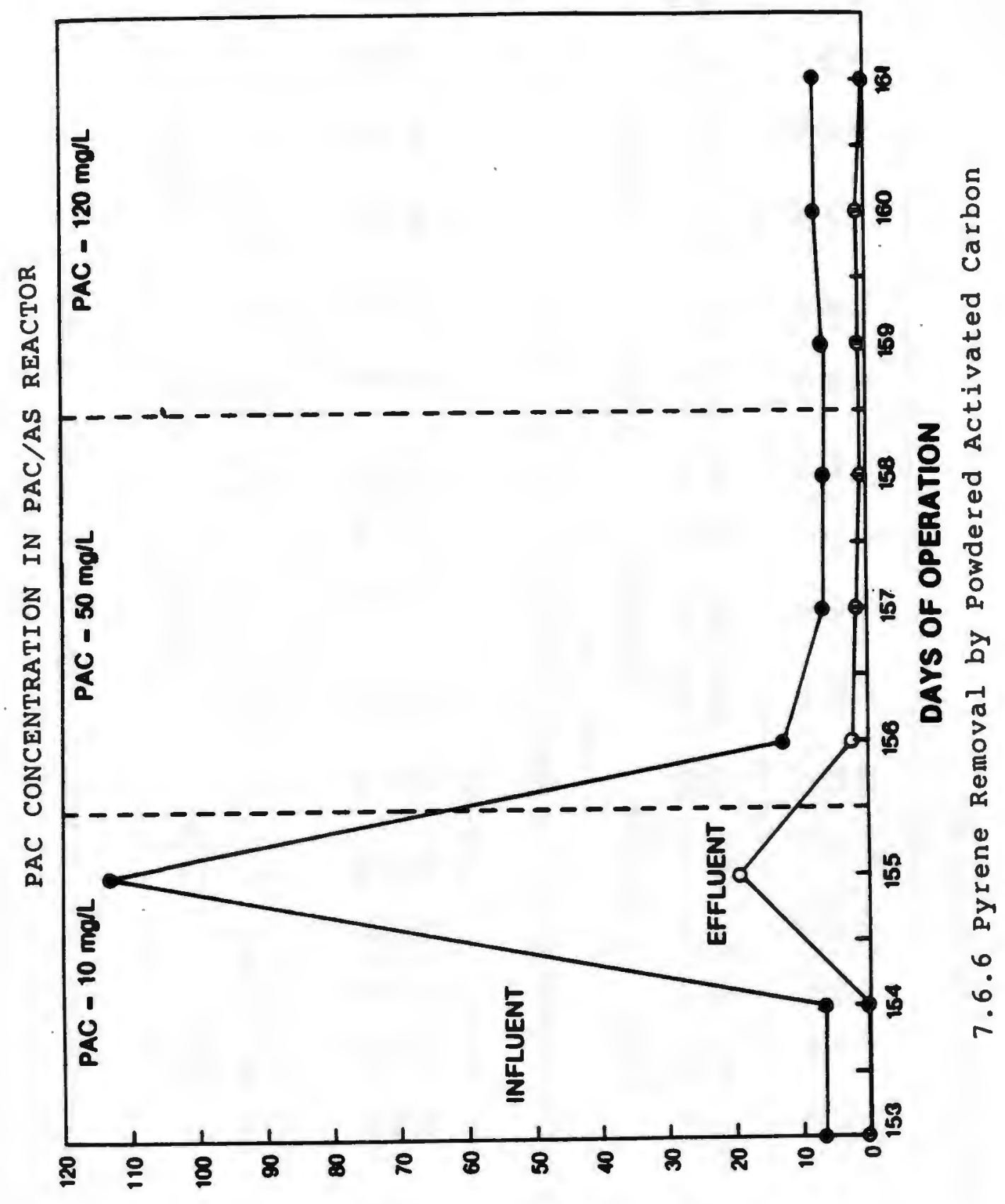

7/6n 'NOILY\&N3JNOS כNaYAd 
Table 7.6.8 Volatile Compounds Removal Efficiencies in Experiment 4, when PAC $=50 \mathrm{mg} / \mathrm{L}$.

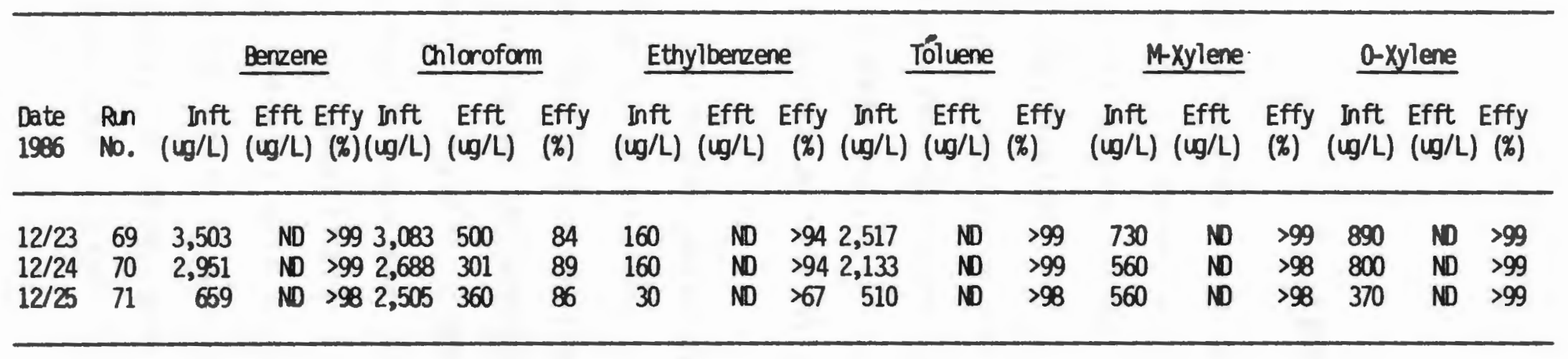

Table 7.6.9 Volatile Compounds Renoval Efficiencies in Experiment 4, when $P A C=120 \mathrm{mg} / \mathrm{L}$.

Benzene Chlorofom Ethylberzene Toluene M-xylene O-xylene

Date Rin Inft Efft Effy Inft Efft Effy Inft Efft Effy Inft Efft Effy Inft Efft Effy Inft Efft Effy

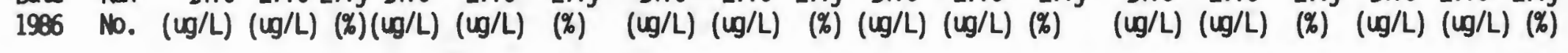

\begin{tabular}{|c|c|c|c|c|c|c|c|c|c|c|c|c|c|c|c|c|c|c|}
\hline $\begin{array}{l}12 / 26 \\
12 / 27 \\
12 / 28\end{array}$ & $\begin{array}{l}72 \\
73 \\
74\end{array}$ & $\begin{array}{l}2,735 \\
2,279 \\
1,638\end{array}$ & $\begin{array}{l}\text { ND } \\
\text { ND } \\
\text { ND }\end{array}$ & $\begin{array}{l}>992,679 \\
>992,597 \\
>99 \\
2,544\end{array}$ & $\begin{array}{r}570 \\
80 \\
224\end{array}$ & $\begin{array}{l}100 \\
100 \\
100\end{array}$ & $\begin{array}{r}190 \\
30 \\
30\end{array}$ & $\begin{array}{l}\text { D } \\
N D \\
N D\end{array}$ & $\begin{array}{l}>95 \\
>67 \\
>67\end{array}$ & $\begin{array}{l}2,000 \\
1,660 \\
1,133\end{array}$ & $\begin{array}{l}N D \\
N D \\
N D\end{array}$ & $\begin{array}{l}>99 \\
>99 \\
>99\end{array}$ & $\begin{array}{r}1,183 \\
865 \\
643\end{array}$ & $\begin{array}{l}N D \\
N D \\
N D\end{array}$ & $\begin{array}{l}>99 \\
>99 \\
>98\end{array}$ & $\begin{array}{r}1,663 \\
1,440 \\
650\end{array}$ & $\begin{array}{l}M \\
N D \\
N D\end{array}$ & $\begin{array}{l}>99 \\
>99 \\
>98\end{array}$ \\
\hline
\end{tabular}

$\mathrm{ND}=$ None detectable, detectability $>10 \mathrm{ug} / \mathrm{L}$ 


\section{CONCLUSIONS}

1. Activated sludge biomass that has been collected from a municipal wastewater treatment facility can be acclimated in a period of 31 days to treat a refinery industrial wastewater.

2. Various stages in the activated sludge biomass acclimation period could be identified by a periodic microscopic examination of the microorganism population.

3. PAC provided a favorable site for the attachment of bacteria.

4. The conventional pollutants $\left(B O D_{5}, C O D\right.$ and $\left.T O C\right)$ which are present in a refinery industrial wastewater can be removed by the activated sludge process and this removal can be enhanced by PAC additions to the AS reactor.

5. Priority organic compounds $(2,4$ dimethylphenol, fluorene, naphthalene and pyrene) were removed by the AS process, PAC additions to the AS reactor improved percentage removals with the exception of pyrene.

6. Volatile organic compounds (benzene, chloroform, ethylbenzene, toluene, $m-x y l e n e$ and $0-x y l e n e)$ were air stripped from the reactor. 


\section{RECOMMENDATIONS}

1. Since concentrations of $0 i 1$ and grease greater than were investigated in this study could be present in a refinery industrial influent especially during API separator upset periods, the effects of these high oil and grease levels on the activity of the biomass should be investigatèd.

2. An investigation should be conducted on the effects of maintaining a DO concentration in the AS reactor in the range of $2 \mathrm{mg} / \mathrm{L}$.

3. It is possible that if a PAC/AS scheme were to be constructed in kuwait to treat the wastewaters from the SIA petrochemical complex, a significant fraction of the total flow would consist of sanitary wastewater. Possible effects of the additions of the sanitary wastewaters should be investigated. 


\section{REFERENCES}

1. Adams, Alan D., "Powdered Carbon: Is it Really That Good?," Water Waste Eng., Vo1. 121, No. B, March 1974, pp. B8-B11.

2. Adams, $A 1$ an D., "Improving Activated Sludge Treatment with Powdered Activated Carbon-Textiles," Presented at the 6th Mid-Atlantic Industrial Waste Conference, University of Delaware, November 15, 1973, pp. 269-283.

3. Alkhatib, Eid A., " Pilot Plant Study For the Treatment of Shuaiba Industrial Area Wastewater In Kuwait," Master Thesis, State University of New York at Buffalo, 1982.

4. "Aquatic Fate Process Data for Organic Priority Pollutants, "Final Report, EPA 440/4-81-014 Environmental Protection Agency.

5. Bellar, T.A., and Lichtenberg, J.J., "Determining Volatile Organics at Microgram per Liter by Gas Chromatography." J AWWA. Vol. 66, December 1974. pp. 739-744.

6. Benefield, Larry D., Judkins, Joseph J., and Weand, Barron L., Process Chemistry For Water and Wastewater Treatment, Prentice-HalT Inc., Englewood CTiffs, New Jersey, T982.

7. Bruvold, William H., "Obtaining Public Support for Reuse Water," Journal AWWA Vol. 77, July, 1985, pp. 72-83.

8. Chao, YU M., and Shieh, Wen K., "PAC-ACtivated Sludge Treatment of Coke-Plant Wastewater," 40th Annual Purdue Industrial Waste Conference, Purdue University, May 14-15, 1985.

9. Chapman, Peter M., Romberg, G. Patrick, and Vigers, Gary A., "Design of Monitoring Studies for Priority Poilutants," Journal WPCF, Vol. 54, No. 1, March 1982, pp. 292-297.

10. Corneille, Richard, "Master Planning a Water Reuse System," Journal WPCF, Vol. 57, No. 3 March 1985, pp. 207-212.

11. Corsmit, C.W.," Paying for Reuse Water," Journal AWWA, Vol. 77, July 1985, pp. 78-83.

12. Crook, James, "Water Reuse in California," Journal AWWA, Vol. 77 July 1985, pp. 60-71. 
13. Culp, Russell L., Wesner, George M., and Culp Gordon L., Handbook of Advanced Wastewater Treatment, Van Nostrand Reinhold Company, New York, 1978.

14. DeBoer, Jon, "Water Reuse: The Second Time Around," Journal AWWA, Vol. 77, July 1985, page 51.

15. DeJohn, Paschal B., and Adams, Al an D., "Treatment of $0 i 1$ Refinery Wastewater with Granular and Powdered Activated Carbon," Proceeding of 30th Industrial Waste Conference, Ann Arbor Sci., Ann Arbor, Michigan, 1975, pp. 216-231.

16. DeWalle, Foppe B., and Chian, Edward S., "Biological Regeneration of Powdered Activated Carbon Added to Activated Sludge Units," Water Research Vol. 11, 1977, pp. 439-446.

17. Engelbrecht, R.S., Gaudy, A.F., and Cederstrand, J.M., "Diffused Air Stripping of Volatile Waste Components of Petro-Chemical Wastes," Journal WPCF, Vol. 33, No. 2, February, 1961, pp. 127-135.

18. Environmental Protection Agency, "Federal Register," Vol. 45, No. 231 , November 28, 1980.

19. Federal Register, "Method 601-Purgeable Halocarbons," Vol. 49, No. 209, Friday, October 26, 1984, pp. 29-39.

20. Federal Register, "Method 602-Purgeable Aromatics," Vol . 49, No. 209 Friday, October 26, 1984, pp. 40-48.

21. Ferguson, John F., Deay, George F., Merri11, M. Steve, and Benedict, Arthur H., "Powdered Activated Carbon Biological Treatment: Low Detention Time Process." Proceeding of the 31 th Industrial Waste Conference, Purdue University, Ann Arbor Sci, Ann Arbor, Michigan, 1976, pp. 468-478.

22. Flynn, Brian P., Robertaccio, Francis L. and Barry, Louis T., "Truth or Consequence: Biological Fouling and Other Considerations in the Pondered Activated Carbon-Activated Sludge System," Proceeding of 31 th Purdue Waste Conference, Purdue University, Ann Arbor Science, Ann Arbor Michigan, 1976, pp. 855-862.

23. Flynn, Brian P., "A Model for the Powdered Activated CarbonActivated Sludge Treatment system," Proceeding of 30th Industrial Waste Conference, Ann Arbor Science, Ann Arbor, Michigan, 1975, pp. 233-252. 
24. Flynn, Brian P., and Stadnik, John G., "Start-up of the Powdered Activated Carbon-Activated Sludge Treatment System," Journal WPCF Vol. 51, No. 2 February, 1979, pp. 358-368.

25. Frohlich, Gerhard et al., "Performance of a Biophysical Treatment Process on a High Strength Industrial Waste," 31 st Annual Purdue Industrial Waste Conference, May, 1976.

26. Gallagher, John R., and Mayer, Gale G., "Process Performance of Pilot-Scale Activated Siudge Treatment of Pretreated Coal Gasification Wastewater," 40th Annual Purdue Industrial Waste Conference, Purdue University, May 14-15, 1985.

27. Garcia-Orozco, Jorge H., Fuentes, Hector R., and Eckenfelder, W. Wesley, "Modeling and Performanced of the Activated Sludge-Powdered Activated Carbon Process in the Presentce of 4,6 - Dinitro-o-cresol." Journal WPCF, Vol. 58, No. 4, April, 1986, pp. 320-325.

28. Gaudy, A.F., and Englebrecht, R.S., "The Stripping of volatile Compounds," Proceedings of the Fifteenth Industrial Waste Conference, Extention Series No. 106, Purdue University, May 3, 4, and 5, 1960, pp. 224-234.

29. Gaudy, A.F., Turner, B.G. and Pusztaszeri S., "Biological Treatment of Volatile Waste Components." Journal WPCF, Vol. 35, No. 1, January 1963, pp. 75-93.

30. Ghannoum, M., Thomson, M., Bowman, W., and Al-Khalil S., "Mode of Action of the Antimicrobical Compound 5-Bromo 5 nitro - 1,3 dioxane (Bronidox)," Folia Microbiologica, Vol $31,1986, \mathrm{pp} .19-31$.

31. Goff, James D., and Busch Paul L., "Reclaiming Desert Lands through Water Reuse," Journal AWWA Vol. 77, July 1985, pp. 84-87.

32. Grabowski, Theodore M., and Vogt, Kenneth L., "A Cooperative Effort Between Publicly Owned Treatment Works and Industrial Users Concerning Industrial Wastewater Management," Sun Refining and Marketing Company, Marcus Hook, Pa., 1986.

33. Hammer, Mark J., Water and Wastewater Technology, Second Edition, John Wi ey \& Sons, New York, 1986.

34. Heath, Harry W., "The PACT Process to Treat 40 MGD of Industrial Wastewater-Updated," E.I. du Pont de Nemours \& Company, Deepwater, NJ, 1986. 
35. Heath, Harry W., "Full-Scale Demonstration of Industrial Wastewater Treatment Utilizing Du Pont's PACT Process, " EPA - 600/52-81-159, Environmental Protection Agency, Dec. 1981.

36. Heath, Harry W., "Update on the PACT Process", E.I. du Pont de Nemours \& Company, Inc., Deepwater, New Jersey, 1986.

37. Janeczek, Joseph, and Lamb, James C., "Treatability of a Gasification Wastewater Using the Powdered Activated Carbon/Activated Sludge Process," Proceedings of 37 th Industrial Purdue Waste Conference, Purdue University, Ann Arbor Sci., Ann Arbor, Michigan, 1983, pp. 397-505.

38. Keith, Larry H., and Teilliard, William A., "Priority Pollutants I - A Perspective View," Environmental Science and Technology Vol. 13, No. 4, April 1979, pp. 416-423.

39. Kincannon, Don F., Stover, Enons L. and Chung, Yu-Ping, "Biological Treatment of Organic Compounds Found in Industrial Aquaeous Effluent, "Presented at American Chemical Society, National Meeting, Atlanta Ga., March 29,- April 3, 1981.

40. Kincannon, Don F., Stover, Enos L., Nichols, Virgil, and Medley, David, "Removal Mechanisms for Toxic Priority Pollutants," Journal WPCF, Vol 55, No. 2, February 1983, pp. 157-163.

41. Lafrance, P., and Villessot M., "Bacterial Growth on Granular Activated Carbon, An Examinattion by Scanning Electron Microscopy." Water Resources, Vo. 17, No. 10, 1983, pp. 1467-1470.

42. Lauer, William C., Rogers, Stephen E. and Ray, Jean M., "The Current Status of Denver's Potable Water Reuse Project," Journal AWWA, Vol. 77, July 1984, pp. 52-59.

43. Leipzig, N.A., and Hockenbury, M.R., "Powdered Activated Carbon/Activated Sludge Treatment of Chemical Production Wastewaters," Proceedings of the 34th Industrial Waste Conference, Purdue University, Ann Arbor Sci., Ann Arbor, Michigan, 1979, pp. 195-205.

44. Lovett, D.A., Travers, S.M., and Davey, K.R., "Activated Sludge Treatment of Abattoir Wastewater - I, "Water Resources, Vol 18, No. 4, 1984, pp. 429-434.

45. Mahmud, Zahib, and Thanh, Nguyen Cong, "Biological Treatment of Refinery Wastes," Proceedings of the 33rd Industrial Waste Conference, Purdue University, Ann Arbor Sci, Michigan, 1979, pp. 515-526. 
46. MCClue, A.F., "Industrial Wastewater Recovery and Reuse," Journal AWWA, Vol. 66, April 1976, pp. 240-253.

47. Mckay, G., Bino, M.J., and Althamemi, A.R., "The Adsorption of Various Pollutants from Aqueous Solutions on to Activated Carbon, "Water Resources, Vol 19, No. 4, 1985, pp. 491-495.

48. Metcalf and Eddy, Wastewater Engineering Treatment Disposal Reuse, McGraw-HiTT Book Company, New York 1979.

49. Nellor, Margaret H., Baird, Rodger B., and Smyth, John R., "Heal th Effects of Indirect Potable Water Reuse, " Journal AWWA, Vol. 77, July 1985, pp. 88-96.

50. Nyer, Evan K.," Groundwater Treatment Technology," Van Nostrand Reinhold Company, New York, 1986.

51. Osantowski, R., Dempsey, Clyde R., and Kenneth, A. Dostal, "Enhanced COD Removal from Pharmaceutical Wastwater Using Powdered Activated Carbon Addition to the Activated Sludge System," 40th Annual Purdue Industrial Waste Conference, Purdue University, May 14-16, 1985.

52. Perrich, Jerry R., "Activated Carbon Adsorption for Wastewater Treatment." CRC Press, Florida 1981.

53. "Powdered Carbon: Right Combination at Right Time." Reactor Journal, No. 57, A Zimpro, Inc. publication, June 1986, pp. 5-6.

54. Reitano, A.J., "Start-up and Operation of a Refinery Activated Sludge Plant," Proceeding of the 36 th Industrial Waste Conference, Purdue University, Ann Arbor, Sci, Michigan, 1982, pp. 310-319.

55. Shannon, J. Dan, Derrington Bob, and Varma, Ashok, "Multipurpose Wastewater Reuse." Journal WPCF, Vol. 58, No. 11, November 1986, pp. 1039-1049.

56. Shaul, Glen M., Dempsey, Clyde R., and Dostal, Kenneth A., "Removal of AZO Dyes by Activated Sludge Process," 40th Annual Purdue Industrial Waste Conference, May 14-16, 1985.

57. Schroeder, Edward D., Water and Wastewater Treatment, McGraw-Hill, New York, 1977.

58. Shuaiba Area Authority," Assessment of Industrial Wastewater Pollution at Shuaiba Industrial Area," SAA, Kuwait, 1983. 
59. Shuaiba Area Authority," Directory of Information and Regulations," Shuaiba, State of Kuwait, 1980.

60. Specchia, V., and Gianetto, A., "Powdered Activated Carbon In An Activated Sludge Treatment Plant," Water Resources Vol. 18, No. 2 1984, pp. 133-137.

61. "Standard Methods for the Examination of Water and Wastewater WPCF, Sixteenth Edition, 1985 .

62. Stensel, H.D., Shell, Gerald L., and Don, Newton, "Biological and Carbon Adsorption Treatment of a Refinery Wastewater," Industrial Waste Conference Purdue Un. Proceedings, Volume 28, Purdue University, Indiana, 1973.

63. Stenstrom, Michael K., and Grieves, Col in G., "Enhancement of $0 i 1$ Refinery Activated Sludge By Addition of Powdered Activated Carbon," Proceeding of the 32nd Industrial Waste 'Conference, Purdue University, Lafayette, Indiana 1977.

64. Stover, Enos L., and Kincannon, Don F., "Biological Treatability of Specific Organic Compounds found in Chemical Industry Wastewaters," Journal of WPCF, Vol ume 55, No. 1, January 1983, pp. 97-109.

65. Tabak, Henery, H., Quave, Stephen A., Mashni, Charles I., and Barth, Edwin F., "Biodegradability Studies with Organic Priority Pollutant Compounds." Journal WPCF, Vol. 53, No. 10, October 1981, pp. 1503 - 1518.

66. Tabak, Henery H., Quave, Stephen A., Mashni, Charles I., Barth, Edwin F., "Biodegradability Studies for Predicting the Environmentatl Fate of Organic Priority Pollutants," Presented at 94 th Annual Association of Official Analytical Chemists (AOAC) Meeting, Arlington, Virginia, October 20-23, 1980.

67. Thiem, Leon, Al-Muzaini, Saleh, and Alkhatib, E., "Ultimate Treatment of SIA Wastewaters for Reuse," Progress Report, February 1986.

68. Thomas, Q.V., Stork, J.R. and Lammert, S.L., "The Chromatographic and GC/MS Analysis of Organic Priority Pollutants in Water, "Journal of chromatographic science, Vol. 18, November, 1980, pp. 583 - 593.

69. Travers, S.M., and Lovett, D.A., "Activated Sludge Treatment of Abattoir Wastewater - II," Water Resource, Vol. 18, No. 4, 1984, pp. 435-439. 
70. Unger, Michael T., and Claff, Roger E., "Evaluation of Percent Removal Variability for Priority Pollutants in DOTWS, " 40th Purdue Industrial Waste Conference, Purdue University, Indiana, May 14-18, 1985.

71. United States Environmental Protection Agency," Carbon Adsorption Isotherms for Toxic Organics," EPA - 600/8-80023, Cincinnati, Ohio, April 1980.

72. U.S. Environmental Protection Agency," Base/Neutrals and Acids Me thods 625," US Environmental Monitoring and Support 1 aboratory, Cincinnati, Ohio, July 1982.

73. Vuuren, L.R.J., Clayton, A.J. and Post, D.C., "Current Status of Water Reclamation at Windhoek, "Journal WPCF, Vol. 52, No. 4, April 1980, pp. 661-671.

74. Wallace, Richard N., and Burns, Don E., "Factors Affecting Powdered Carbon Treatment of a Municipal Wastewater," Journal WPCF, Vol. 48, No. 3 March 1976, pp. 511-519.

75. "Wastewater Treatment Plant Design", Water Pollution Control Federation, Second Printing, Washington, D.C. 1982.

76. Water Pollution Control Federation, "Water Reuse, Manual of Practice SM-3 Systems Management," Washington D.C., 1983.

77. Water Pollution Control Federation," Wastewater Treatment Pl ant Design," WPCF, Washington, D.C., 1982.

78. Water Pollution Control Federation, "Industrial Wastewater Control Program For Municipal Agencies," WPCF, Washington D.C., 1982 .

79. Weber, Walter J., Corfis, Nora H., and Jones, Bruce E., "Removal of Priority Pollutants in Integrated Activated Sludge-Activated Carbon Treatment Systems," Journal WPCF, Vol. 55, No. 4, April 1983, pp. 369-376.

80. Weber, Walter J., Pirbazari, Massoud, and Melson, Gail L., "Biological Growth on Activated Carbon: An Investigation by Scanning Electron Microscopy," American Chemical Society, Vol. 12, No. 7, July 1978, pp. 817-819.

81. Weber, Walter J., "Potential Mechanisms for Removal of Humic Acids From Water By Activated Carbon," Ann Arbor Science, Michigan, 1980, pp. 317-336.

82. Wells, 0liver C., Scanning Electron Microscopy, McGrawHill Book Co., New York, 1974. 
83. Zimpro Inc., "Biomass Determination - Nitric Acid Digestion Method," Zimpro Inc., Wisconsin, 1985. 
APPENDICES 


\section{Appendix 1}

A List of Priority Pollutants 
Priority Pollutant Compounds

Compound Name

Mole Wt

1. *acenaphthene

154

*acrolein

*acrylonitrile

53

4. *benzene

*carbon tetrachloride (tetrachloromethane)

154

* Chlorinated benzenes (other than dichlorobenzenes)

7. chtorobenzene

8. $\quad 1,2,4-\operatorname{trichl}$ orobenzene

9. hexachiorobenzene

*chlorinated ethanes (including 1,2-dichloroethane, $1,1,-$ thrichloroethane and hexachloroethane)

10. 1,2-dichloroe thane

11. 1,1,1-trichloroethane

12. hexachloroethane

13. 1,1-dichlorethane

14. 1,1,2-trichloroethane

15. 1,1,2,2-te trachloroe thane

16. chloroethane

*Chloroalkyl ethers (chloromethyl, chloroethy 1

17. bix(chloromethy 1$)$ ether

18. bix (2-chloroethyl) ether

19. 2-chloroethyl vinyl ether (mixed)

* chlorinated naphthalene

20. 2-chloronaphthalene

* chlorinated phenols (other than those listed elsewhere; includes trichlorophenols and chlorinated cresols)

21. 2,4,6-trichlorophenol

22. parachlorometa cresol

23. *chlor of orm (trichloromethane)

24. *2-chlorophenol

* Specific compounds and chemical classes as 1 isted in original Consent Decree 
*dishlorobenzenes

25. 1,2-dichtorobenzene 147

26. 1,3-dichlorobenzene 147

27. 1,4-dichlorobenzene 147

*Dichlorobenzidine

28. 3,3-dichtorobenzidine

*Dichloroethylenes $(1,1-$ dichloroethylene

and $1,2-d i c h$ loroethylene)

1,1 -dichloroethylene

30. $1,2-$ trans-dichloroethylene

163

*Dichloropropane and dichloropropene

32. 1,2-dichloropropane

33. 1,2-dichloropropylene (1,3-dichloropropene)

113

34. *2,4-dimethylphenol

*Dinitrotoluene

35. 2,4-dinitrotoluene

36. 2,6, dinitrotoluene

182

37. * $1,2-d i p h e n y l$ hydrazine

184

38. *ethylbenzene

106

39. *Fluoranthene

* Haloethers (other than those listed elsewhere)

40. 4-Chtorophenyl phenyl ether

41. 4-bromopheny1 pheny 1 ther

42. bis (2-chloroisopropyl) ether

43. bis (2-chloroethoxy)methane

* Halomethanes (other than those listed elsewhere)

44. Methylene chToride (dichloromethane)

45. methy chloride ( $\mathrm{chl}$ loromethane

46. methybromide (bromomethane)

47. brom of orm (tribromomethane)

48. dichlorobromome thane

164

49. trichlor of luorome thane

139

50. dichlorodiflorome thane

121

51. chlorodibromomethane

208

52. *hexachlorobutadene

53. *hexachlorocyclopentadiene

54. * isophorone

55. *naphthalene

56. *nitrobenzene

* Specific compounds and chemical classes as listed in original Consent Decree 
* Nitrophenols (including 2,4-dinitrophenol and dinitrocre sol)

57. 2-nitrophenol

58. 4-nitrophenol

139

59. *2,4-dinitrophenol

60. 4,6-dinitro-0-cresol

184

198

* Nitrosamines

61. N-nitrosodimethyl amine

62. N-nitrosodiphenylamine

198

63. N-nitrosodi-n-propylamine 130

64. *pentachlorophenol 266

65. * phenol

*Phthal ate esters

66. bis (2-ethylhexy ) phthalate

67. butyl benzyl phthalate

68. di-n-butyl phthalate

69. Di-n-octyl phthalate

70. diethyl phthalate

71. dimethyl phthalate

* polynuclear aromatic hydrocarbons

72. benzo(a)anthracene (1,2-benzathracene)

73. benzo(a) pyrene (3,4-benzopyrene)

74. 3,4-benz of luor an thene

75. benzo(k) fluoranthene $(11,120$ benzof 1 uoranthene)

76. chrysene

77. acenaphthylene

78. anthracene

79. benzo(ghi)perylene (1,12-benzoperylene)

80. fluorene

81. phenanthrene

82. dibenzo $(a, h)$ anthracene $(1,2,5,6$-dibenzanthracene)

83. ideno ( $1,2,3-c d)$ pyrene $(2,3-0$-phenyl enepyrene)

84. pyrene

85. * tetrrachloroethylene

86. *toluene

87. *trichloroethylene

88. *vinyl chloride (chloroethylene)

* Specific compoiunds and chemical classes as listed in original Consent Decree 
Pesticides and Metabolities

89. *aldrin

90. *dieldrin

91. *chlordane (technical mixture \& metabolities)

*DDt and methabolities

92. 4,4-DOT

93. 4,4-DDE ( $P, P-D D X)$

94. 4,4-DDD ( $P, P-T D E)$

95. $\frac{\text { *endosulfan and metabolities }}{\text { a-endosulfan-Alpha }}$

96. b-endosulfan-Beta

97. endosulfan sulfate

*endrin and metabolities

98. endri

99. endrin aldehyde

*heptachlor and metabolities

100. heptachlor

101. heptachlor epoxide

*hexachlorocyclohexane (al insomers)

102. a-BHC-ATpha

103. b-BHC-Beta

104. $r-B H C$ ( 1 indane)-Gamma

105. g-BHC-Delta * polychlorinated biphenyls (PCBS)

106. PCB-1242 (Archlor 1242)

107. PCB-1254 (Arochlor 1254)

108. PCB-1221 (Arochlor 1221)

109. PCB-1232 (Arochlor 1232)

110. PCB-1248 (Arochlor 1248)

111. PCB-;260 (Arochlor 1260)

112. PCVB-1016 (Arochlor 1016)

113. * Toxaphene

114. *Antimony

115. *Arsenic

116. *Asbestos

117. *Beryllium

118. *Cadmium

119. *Cadmi um

120. *Copper

(Total)

(Total)

(Fibrous)

(Total)

(Total)

(Total)

(Total

* Specific compounds and chemical classes as listed in original Consent Decree 
121. * Cyanide

122. * Le ad

123. * Mercury

124. *Nickel

125. * Se 1 en ium

126. * Silver

127. * Thallium

128 . * Zinc
(Total)

(Total)

(Total)

(Total)

(Total)

(Total)
(Total)

129. *2,3,7,8 - tetrachlorodibenzo-p-dioxin (TCDD)

* Specific compounds and chemical classes as listed in original Consent Decree 
$+$

Experiment 1: Figures for Bio-Kinetic Constants

Appendix 2 


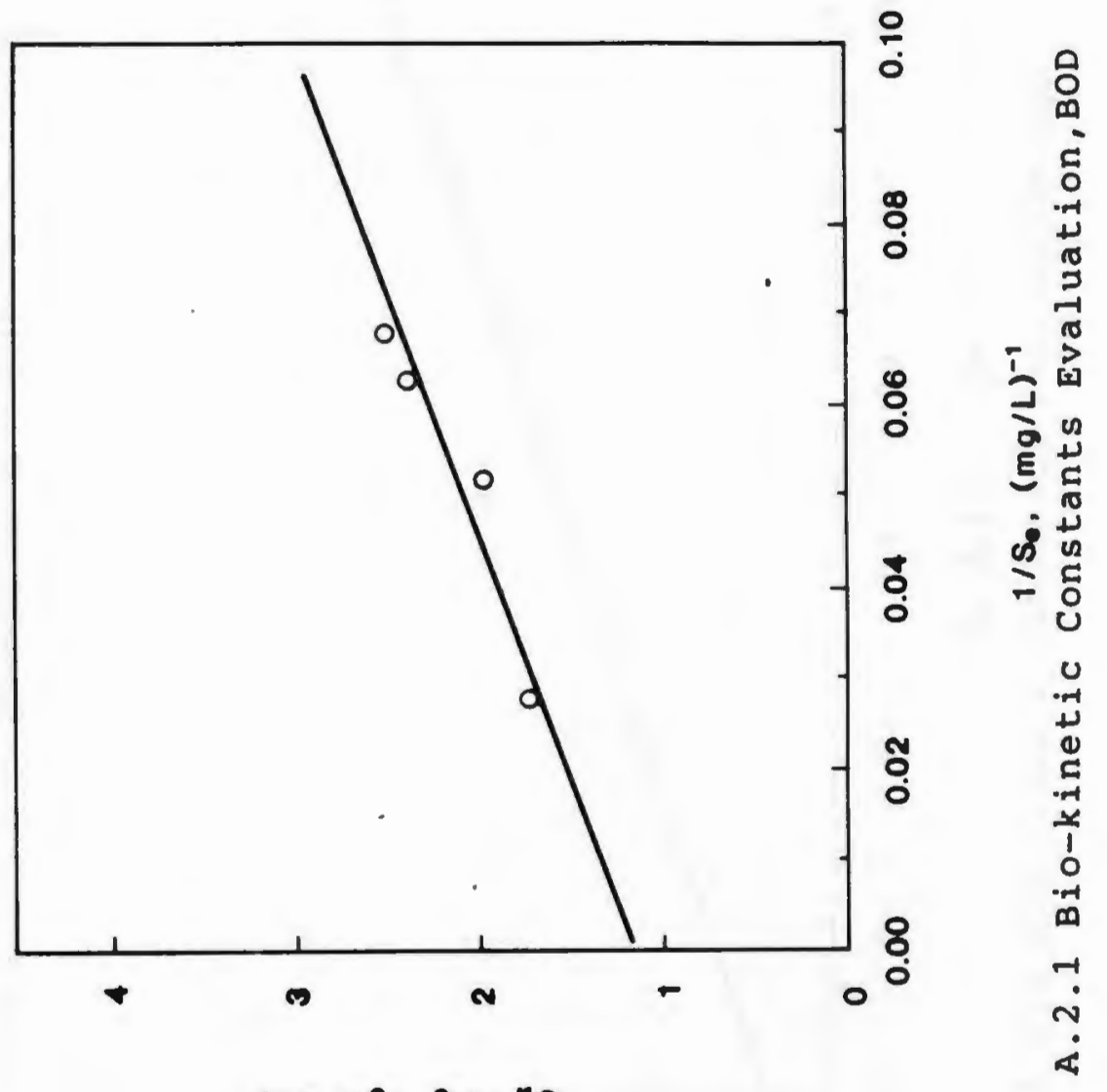

$\operatorname{Nep}(B-s) / \varphi_{\theta}$ 


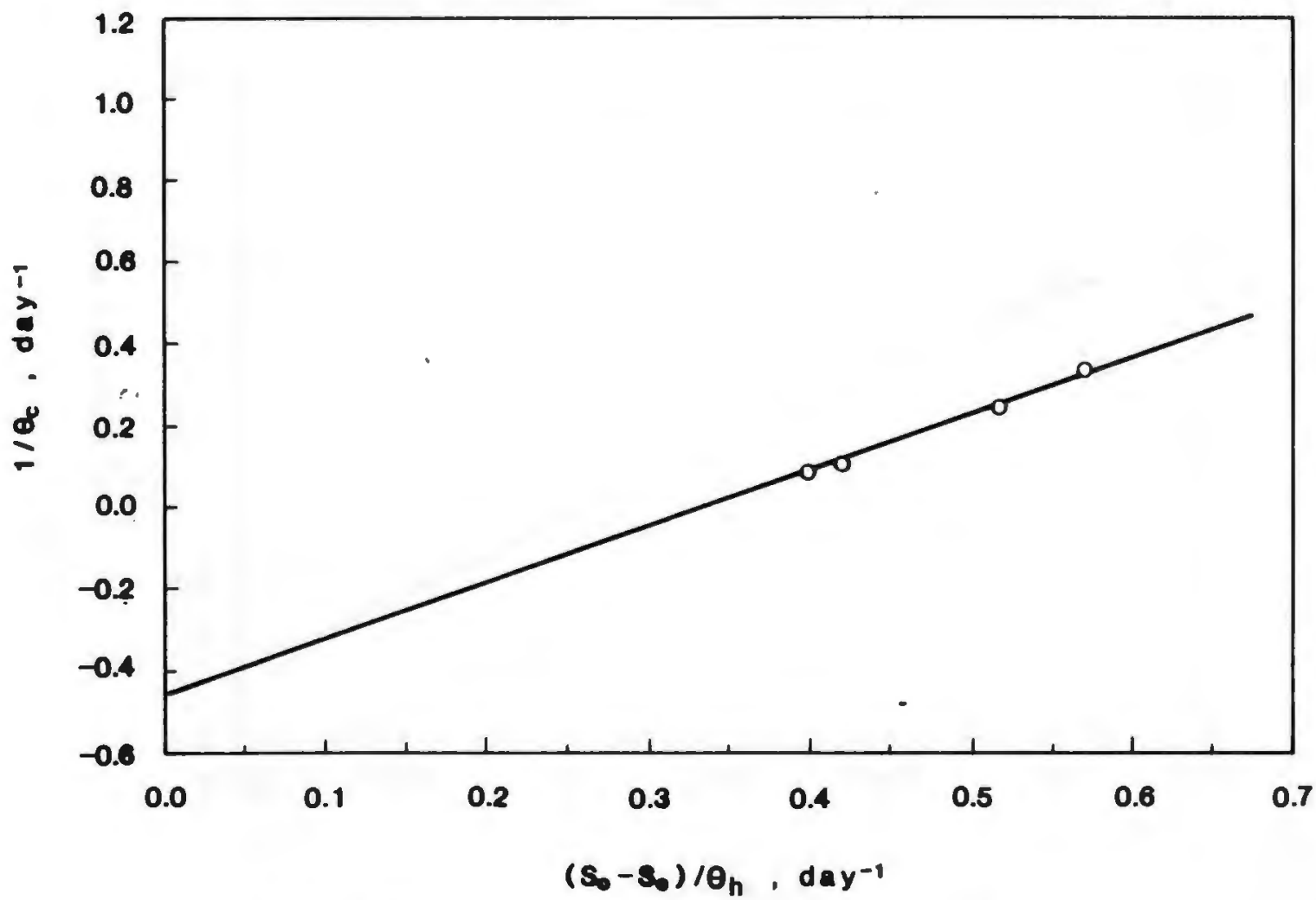

A.2. 2 Bio-kinetic Constants Evaluation, BOD 


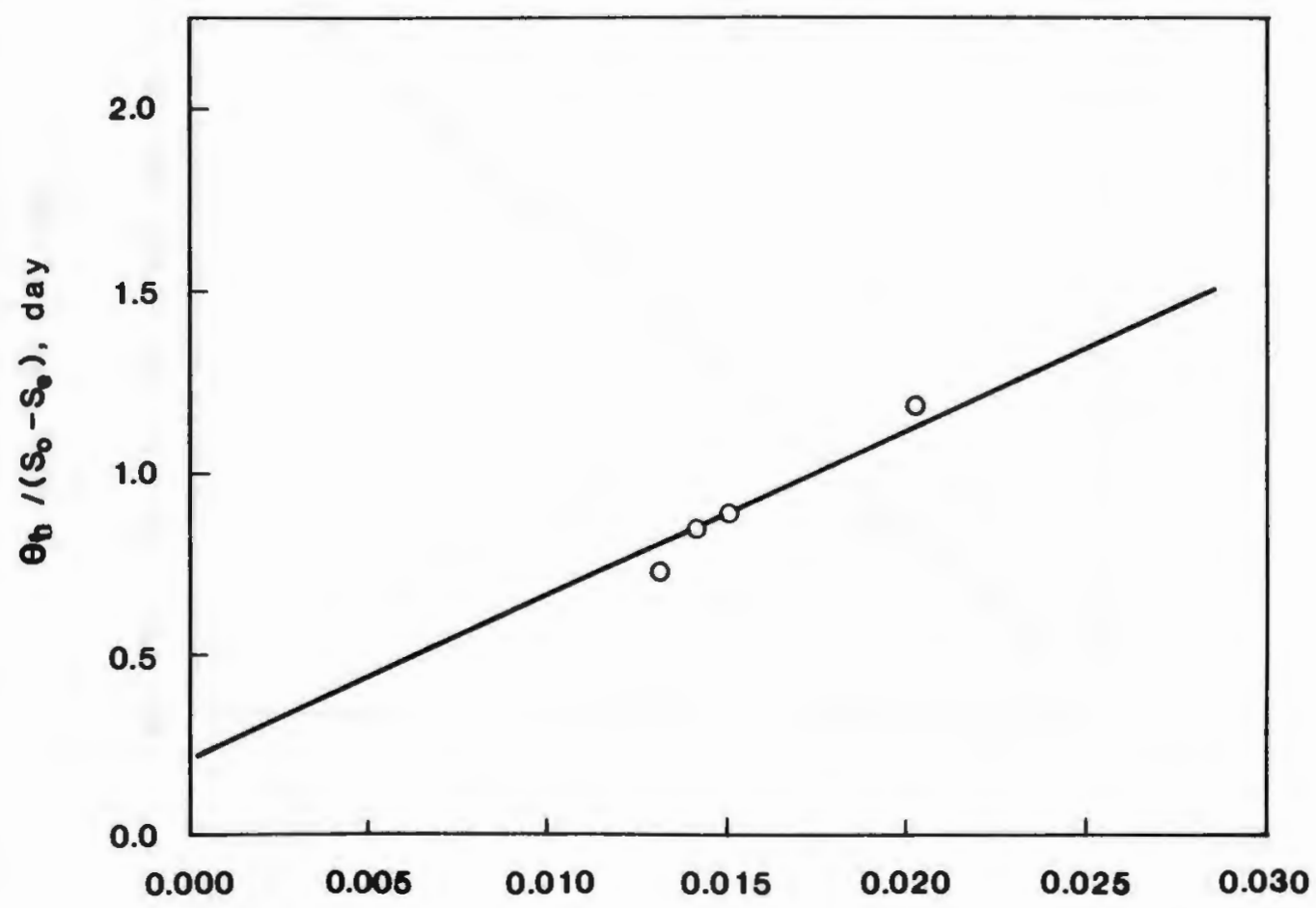

A. 2.3 Bio-kinetic Constants Evaluation, COD 


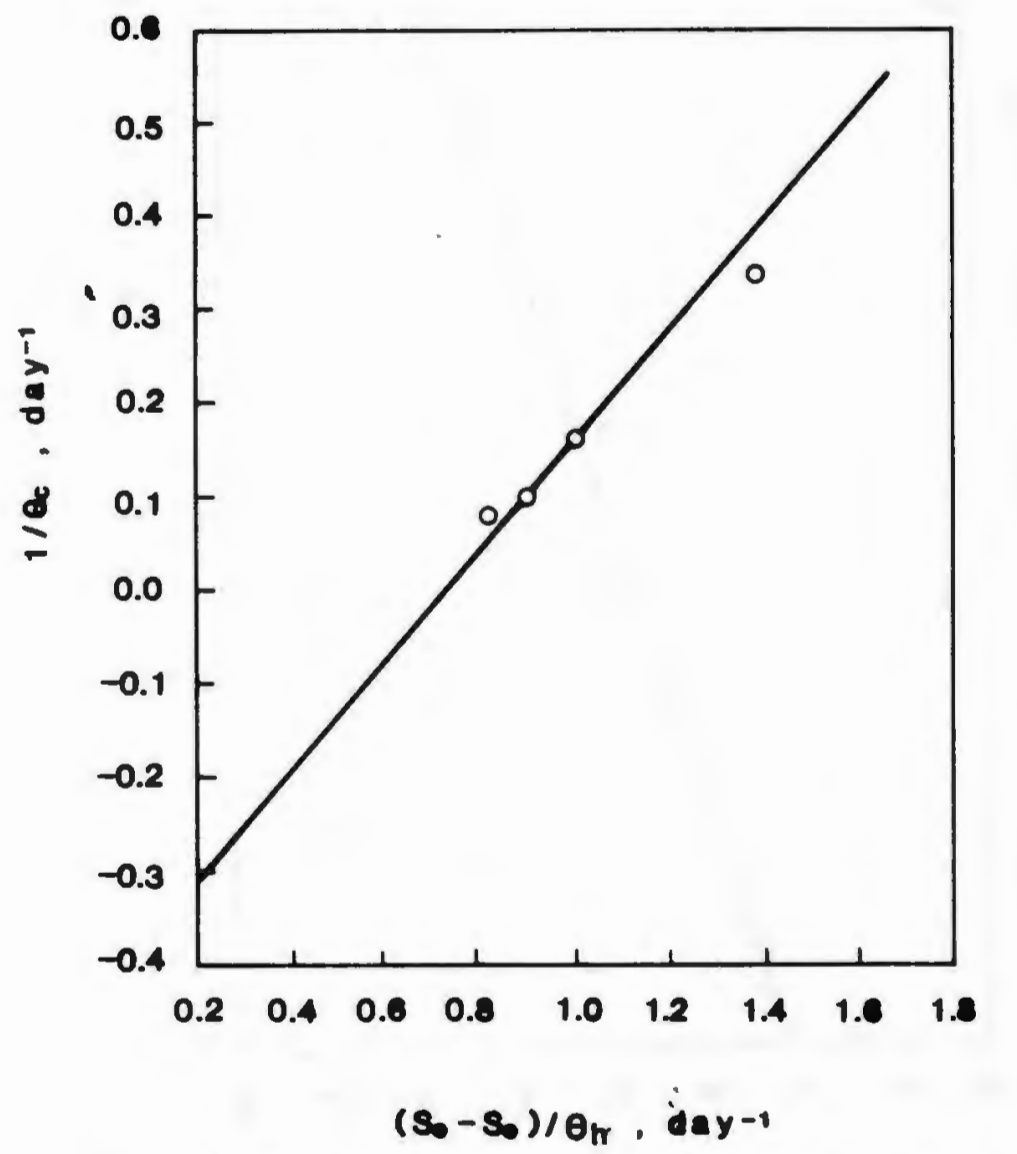

A.2.4 Bio-kinetic Constants Evaluation, COD 


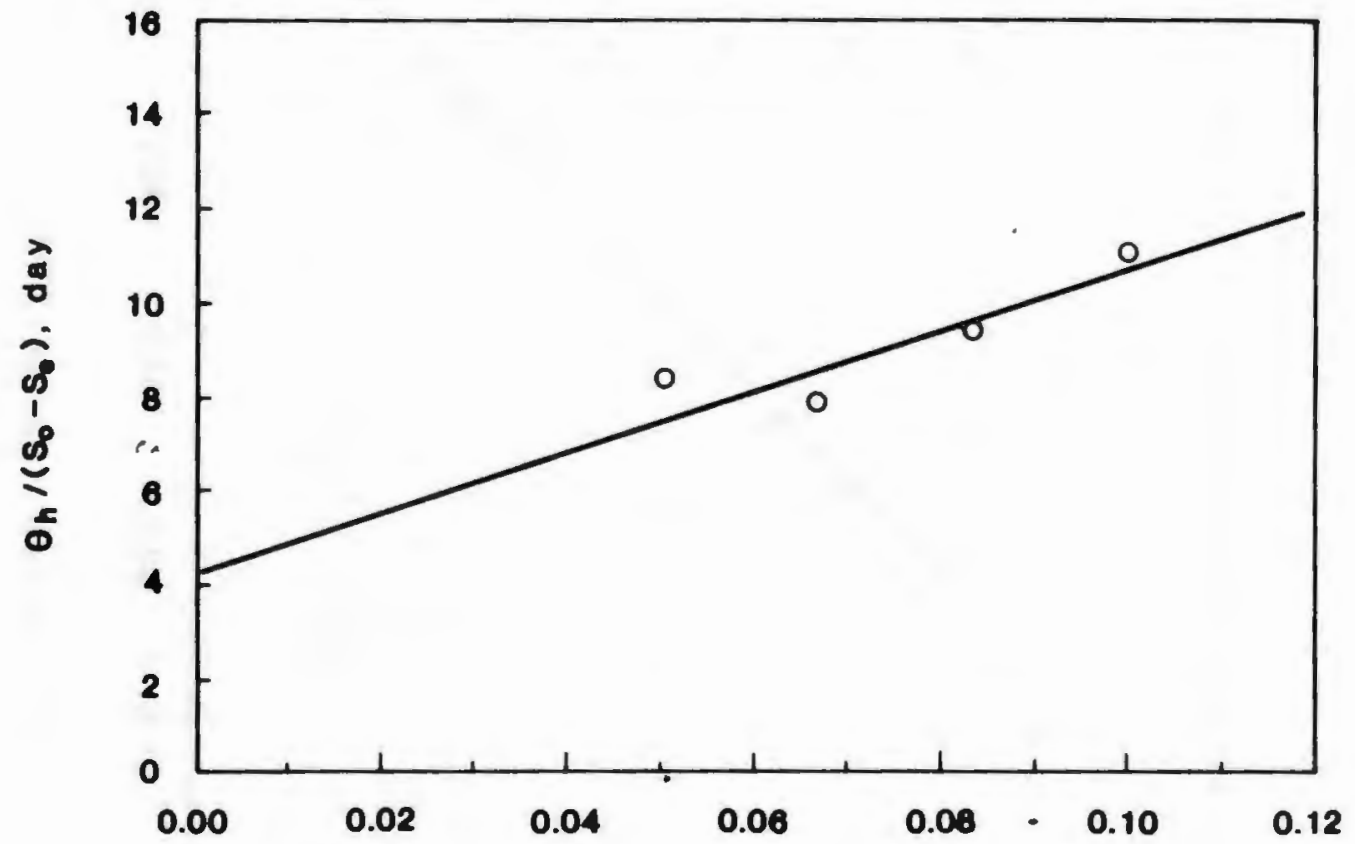

$1 / \mathrm{S}_{0},(\mathrm{mg} / \mathrm{L})^{-1}$

A.2.5 Bio-kinetic Constants Evaluation, TOC 


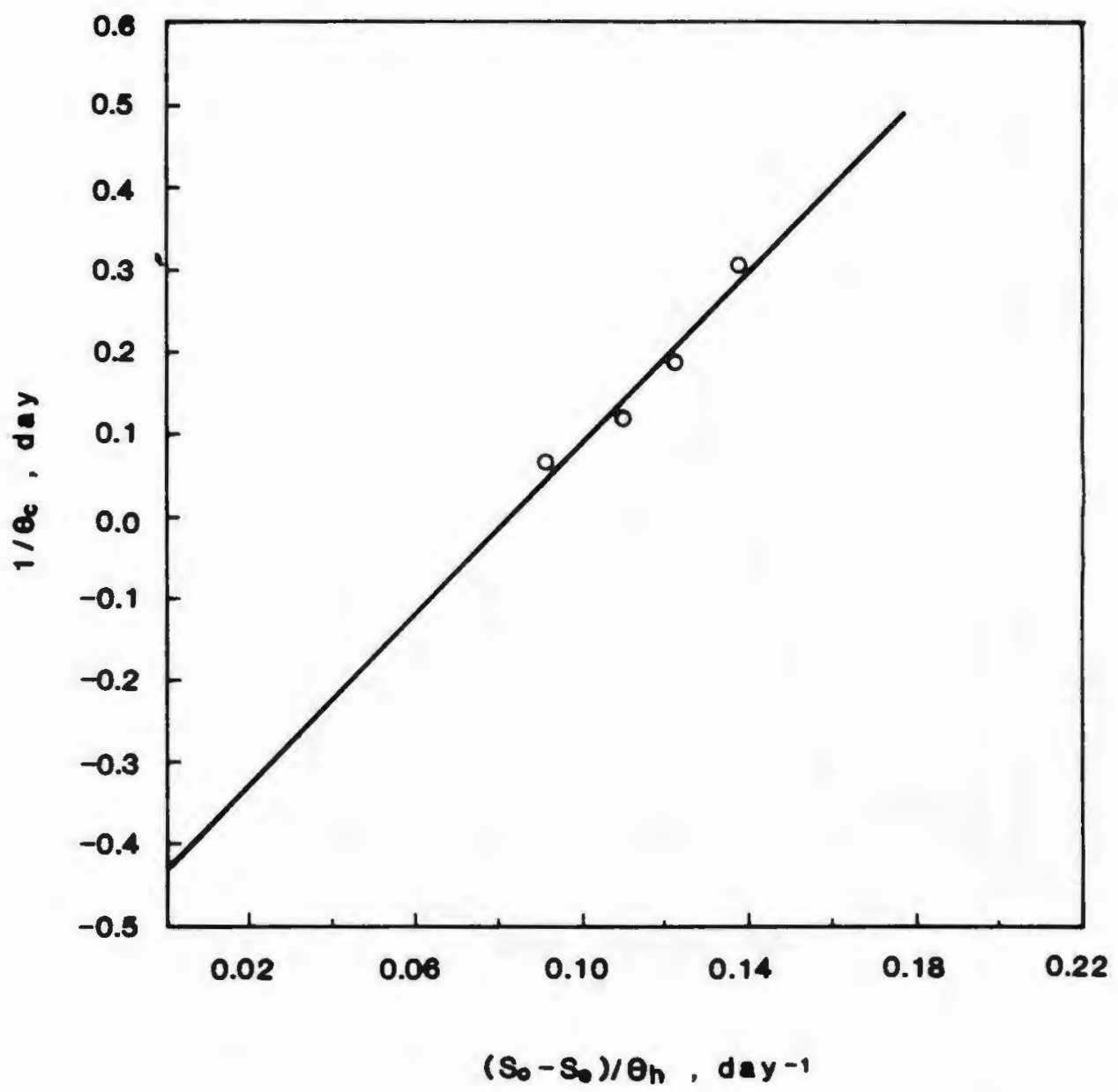

A.2.6 Bio-kinetic Constants Evaluation, TOC 


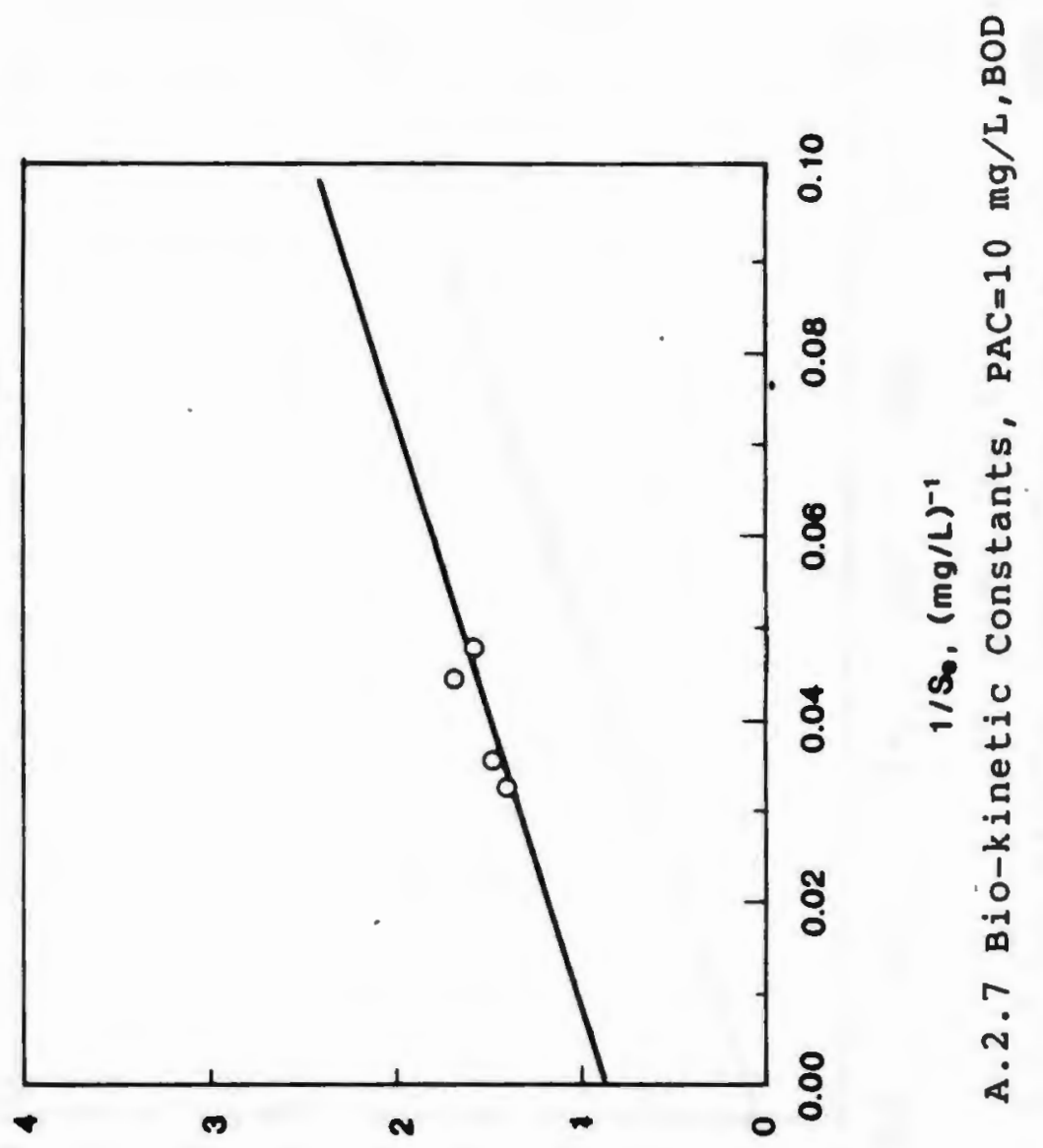

$\Lambda=p(s-.8) /{ }^{4} \theta$ 


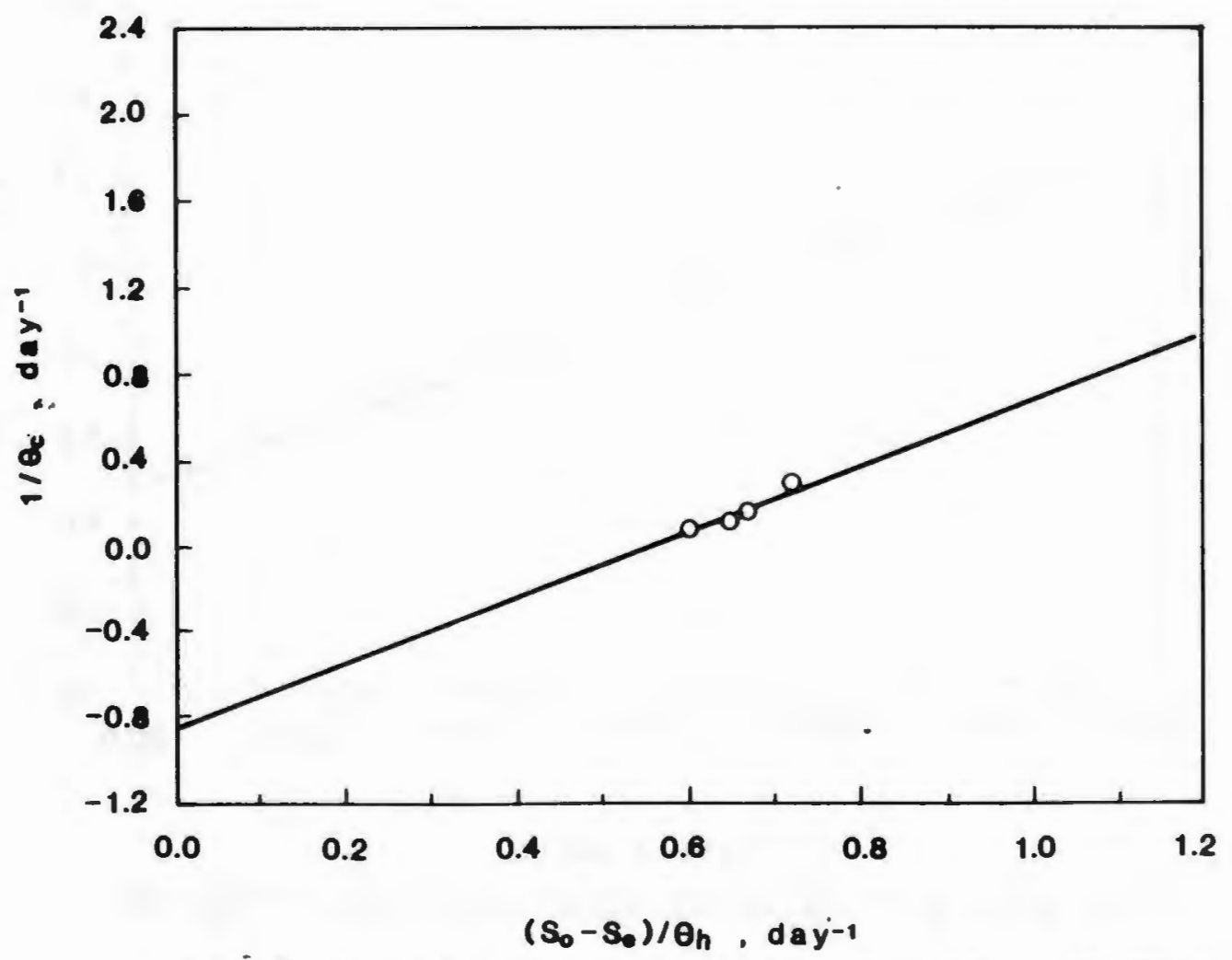

A. 2.8 Bio-kinetic Constants, $\mathrm{PAC}=10 \mathrm{mg} / \mathrm{L}, \mathrm{BOD}$ 


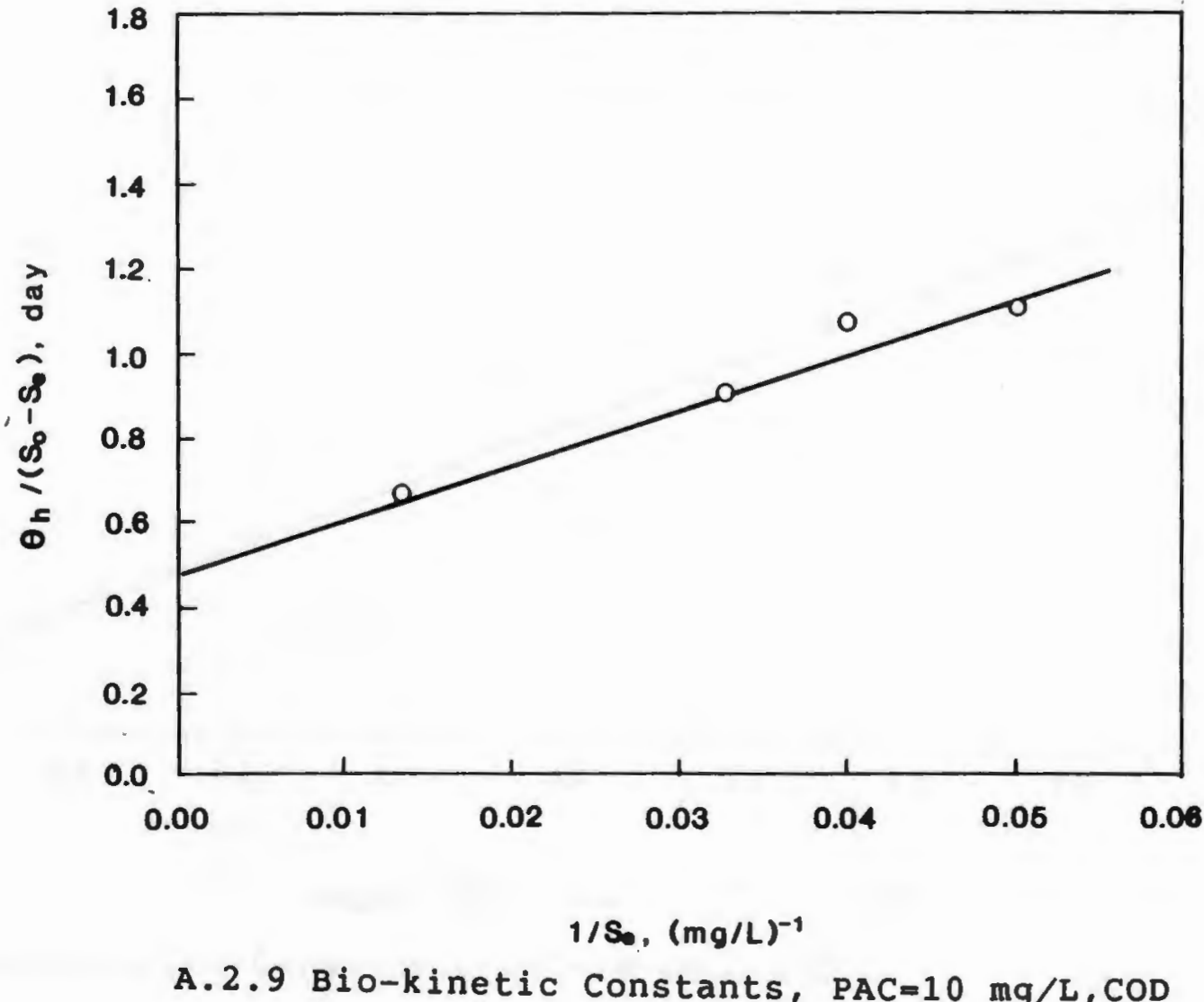




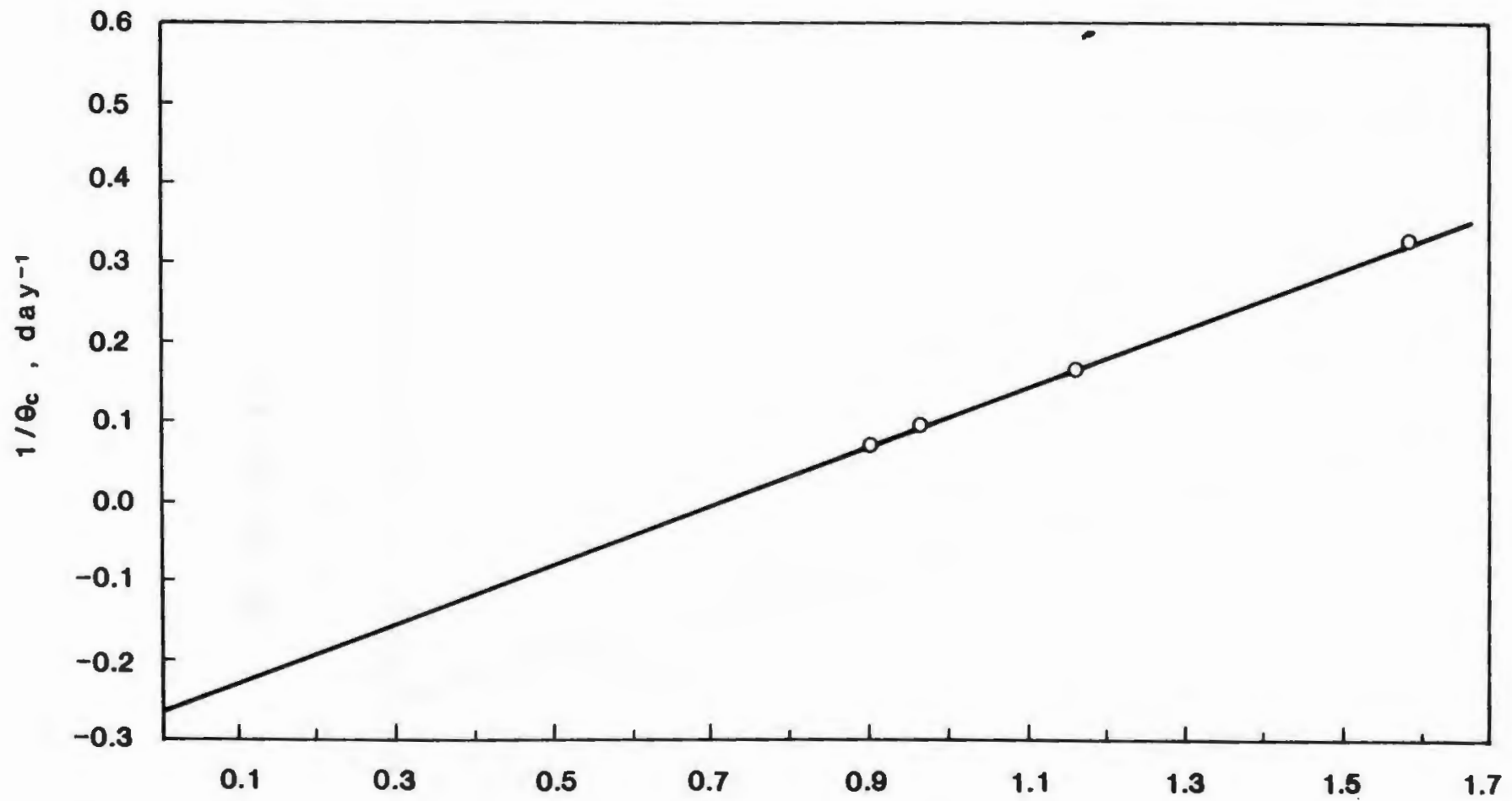

$\left(s_{0}-s_{0}\right) / \theta_{h}, d a y^{-1}$

A.2.10 Bio-kinetic Constants, $P A C=10 \mathrm{mg} / \mathrm{L}, \mathrm{COD}$ 


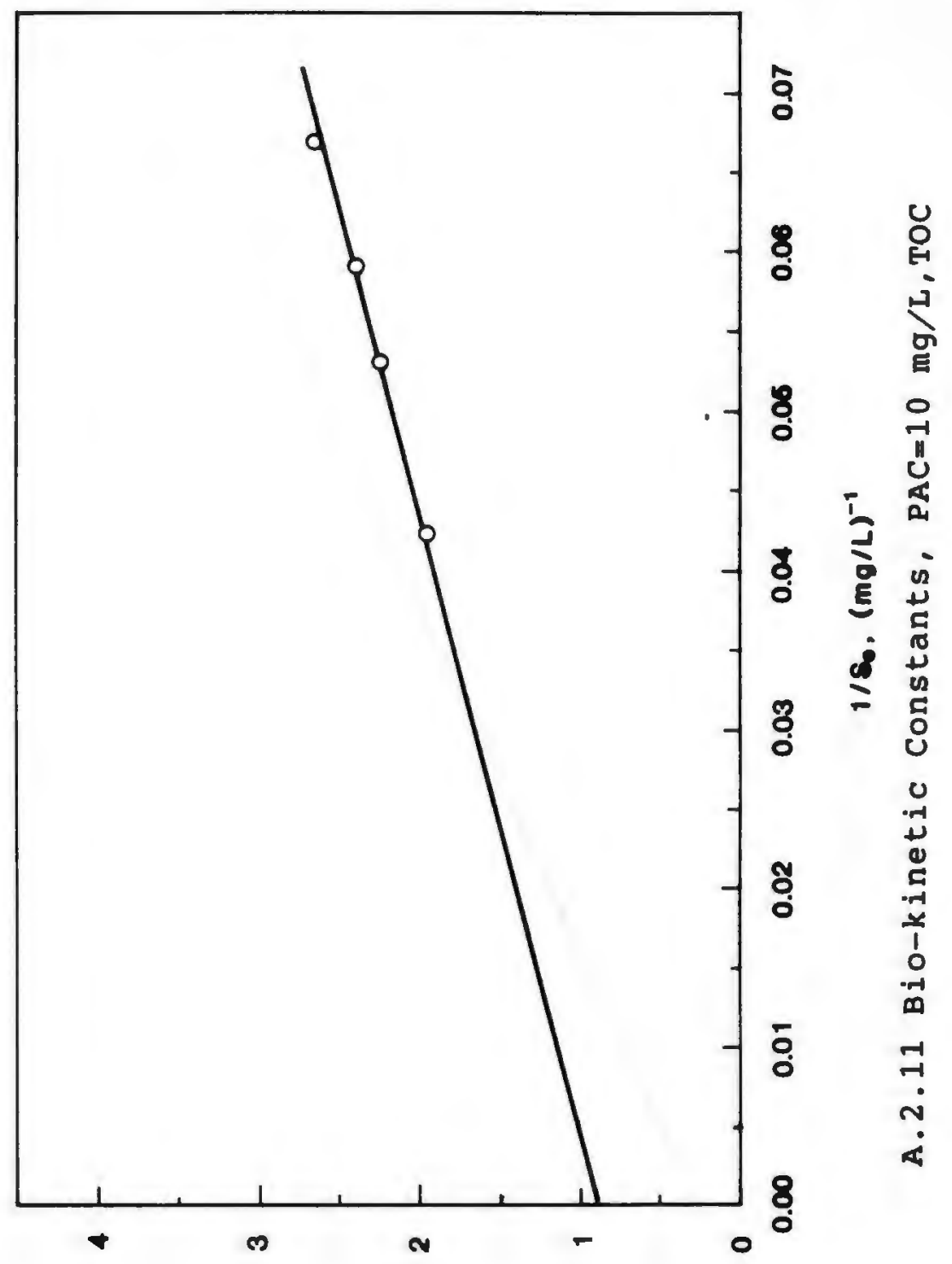

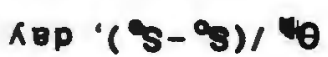




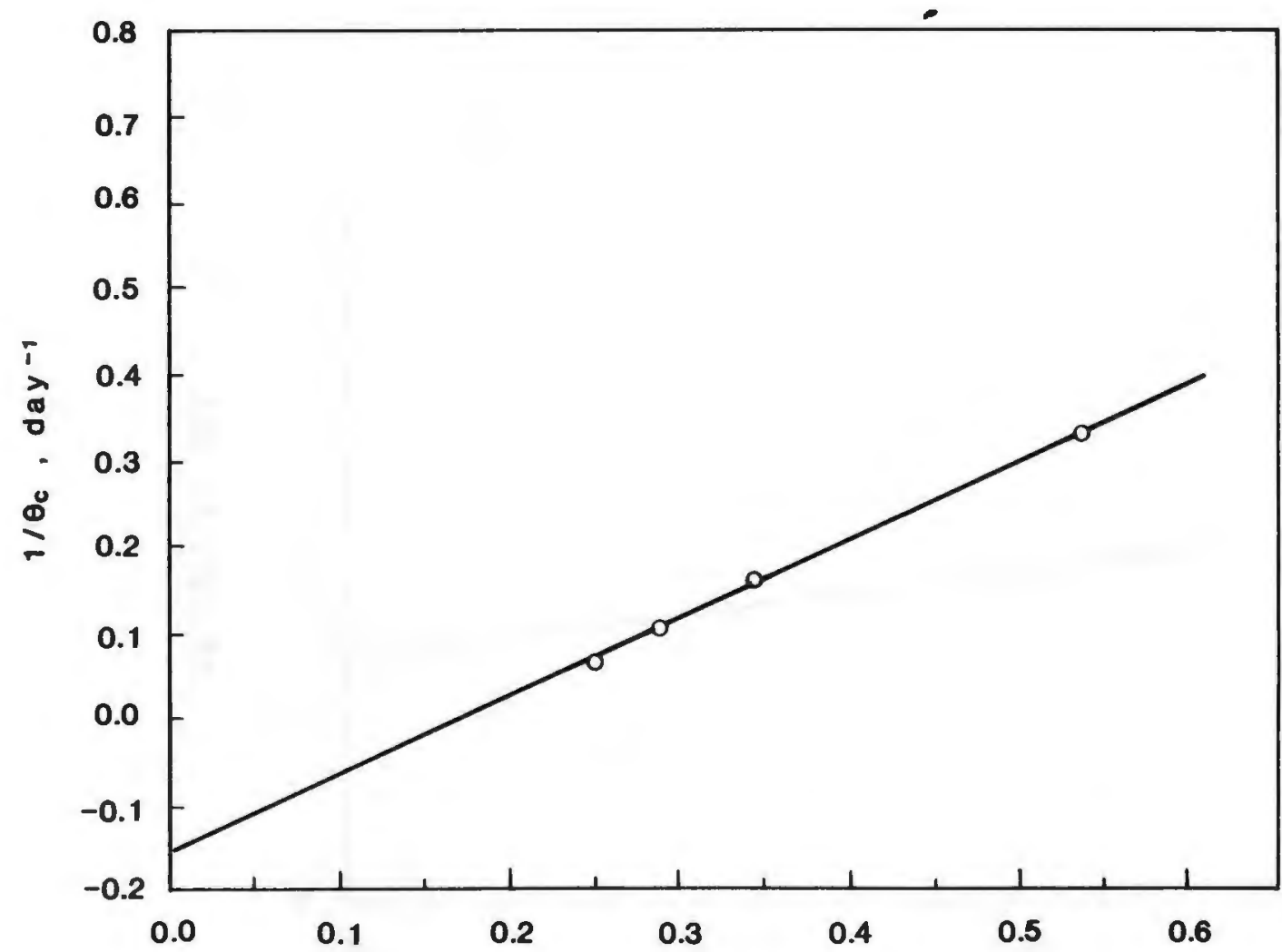

$\left(S_{0}-S_{0}\right) / \theta_{h}, d_{a y}^{-1}$

A. 2.12 Bio-kinetic Constants, PAC=10 mg/L, TOC 


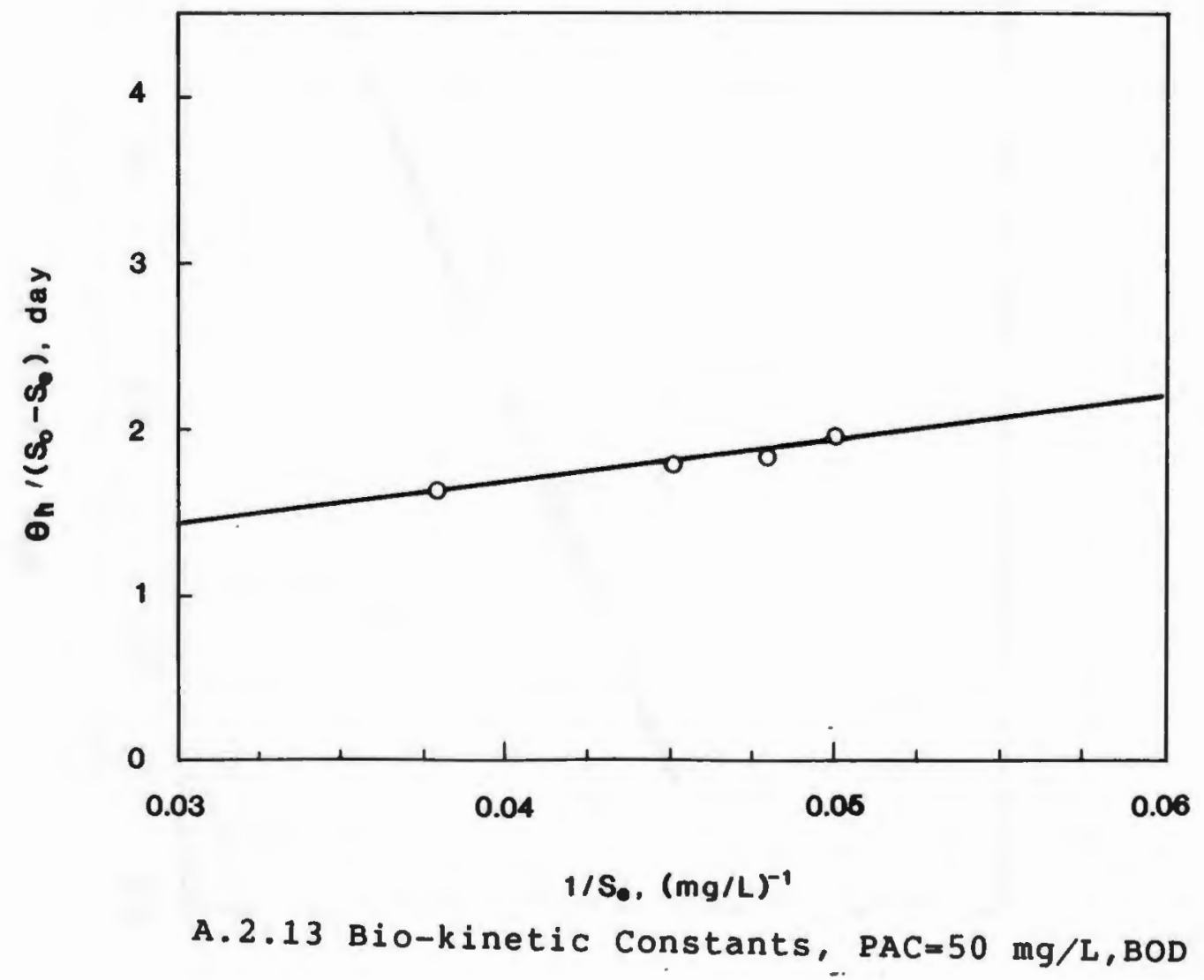




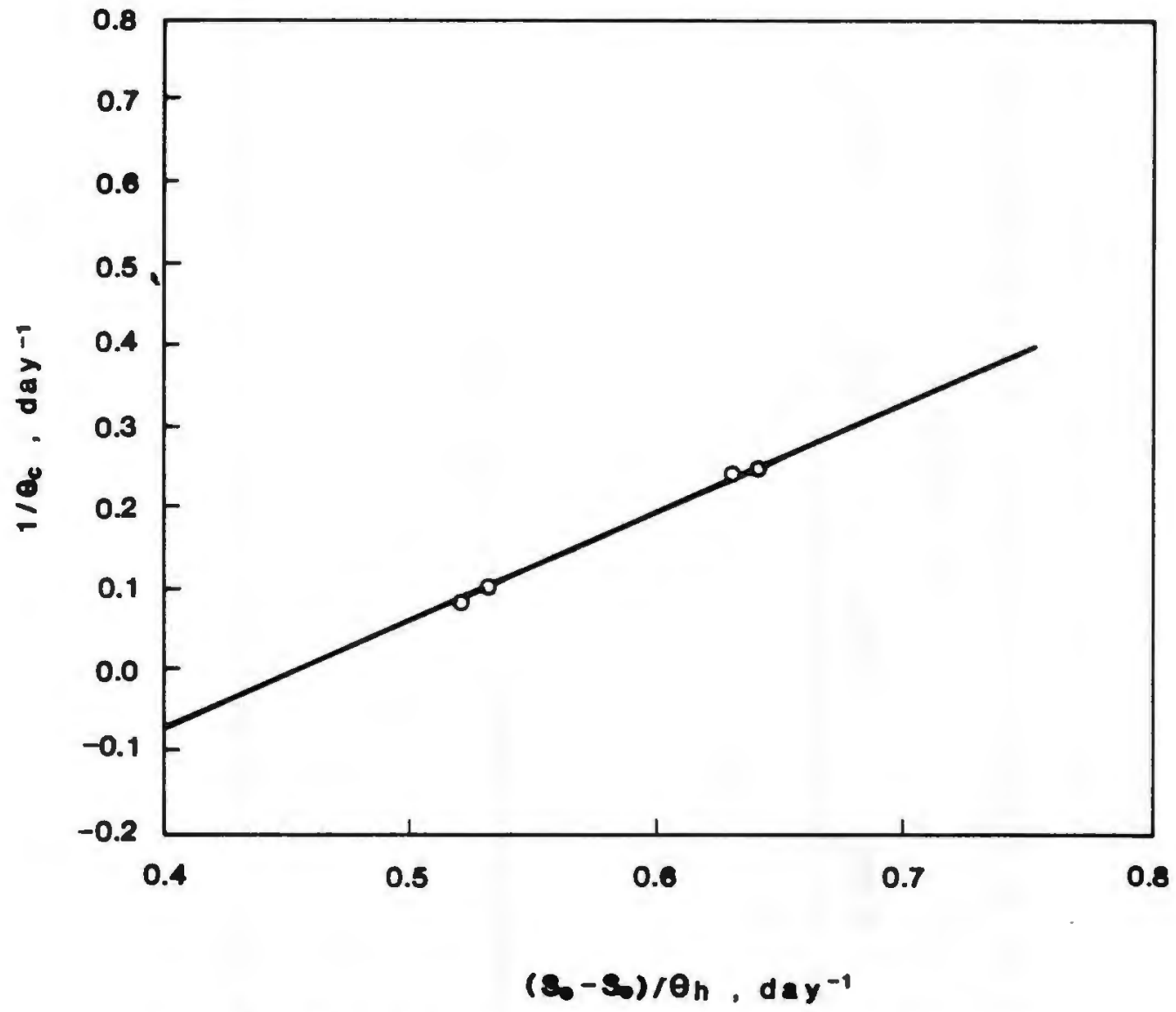

A.2.14 Bio-kinetic Constants, $P A C=50 \mathrm{mg} / \mathrm{L}, \mathrm{BOD}$ 


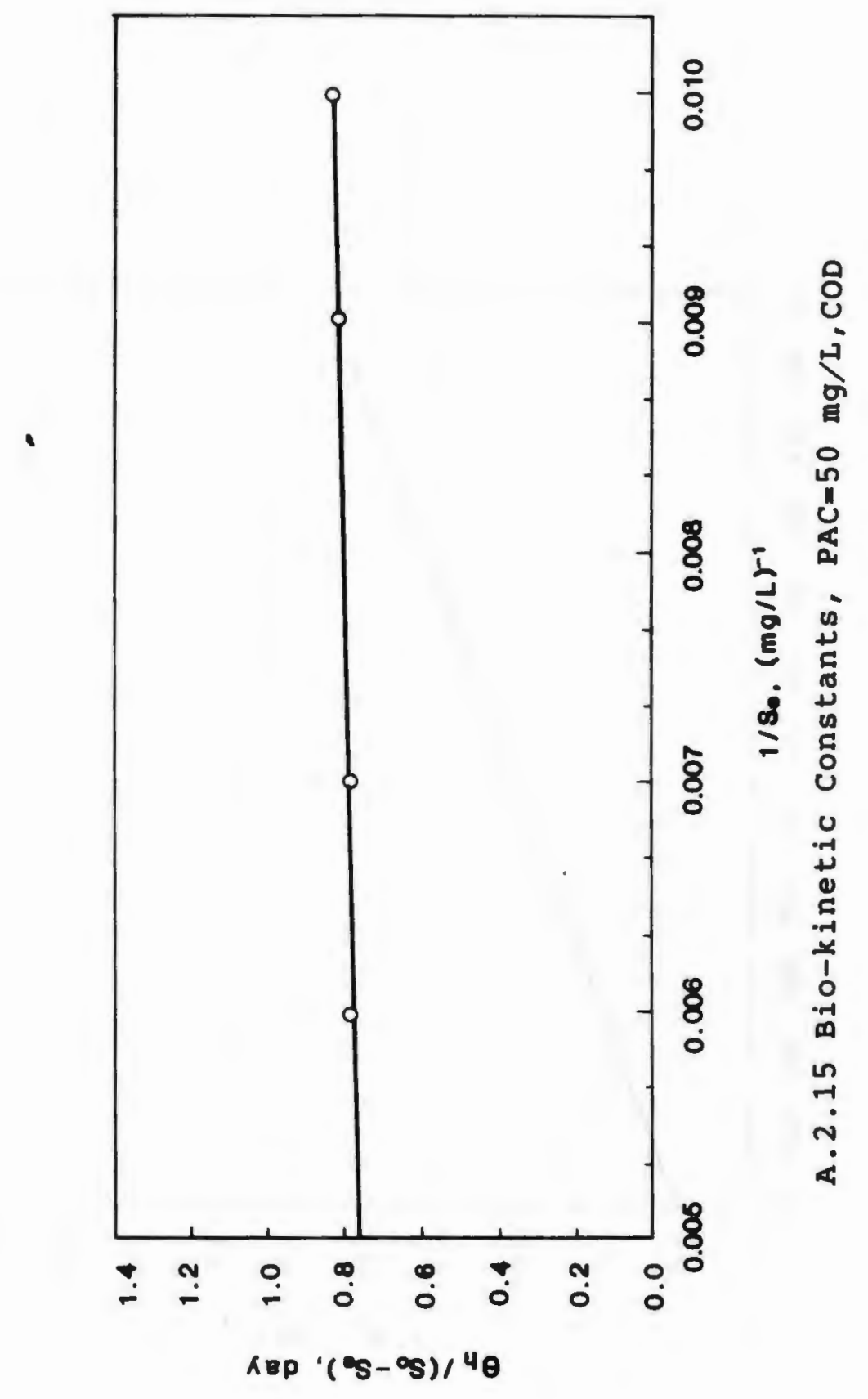




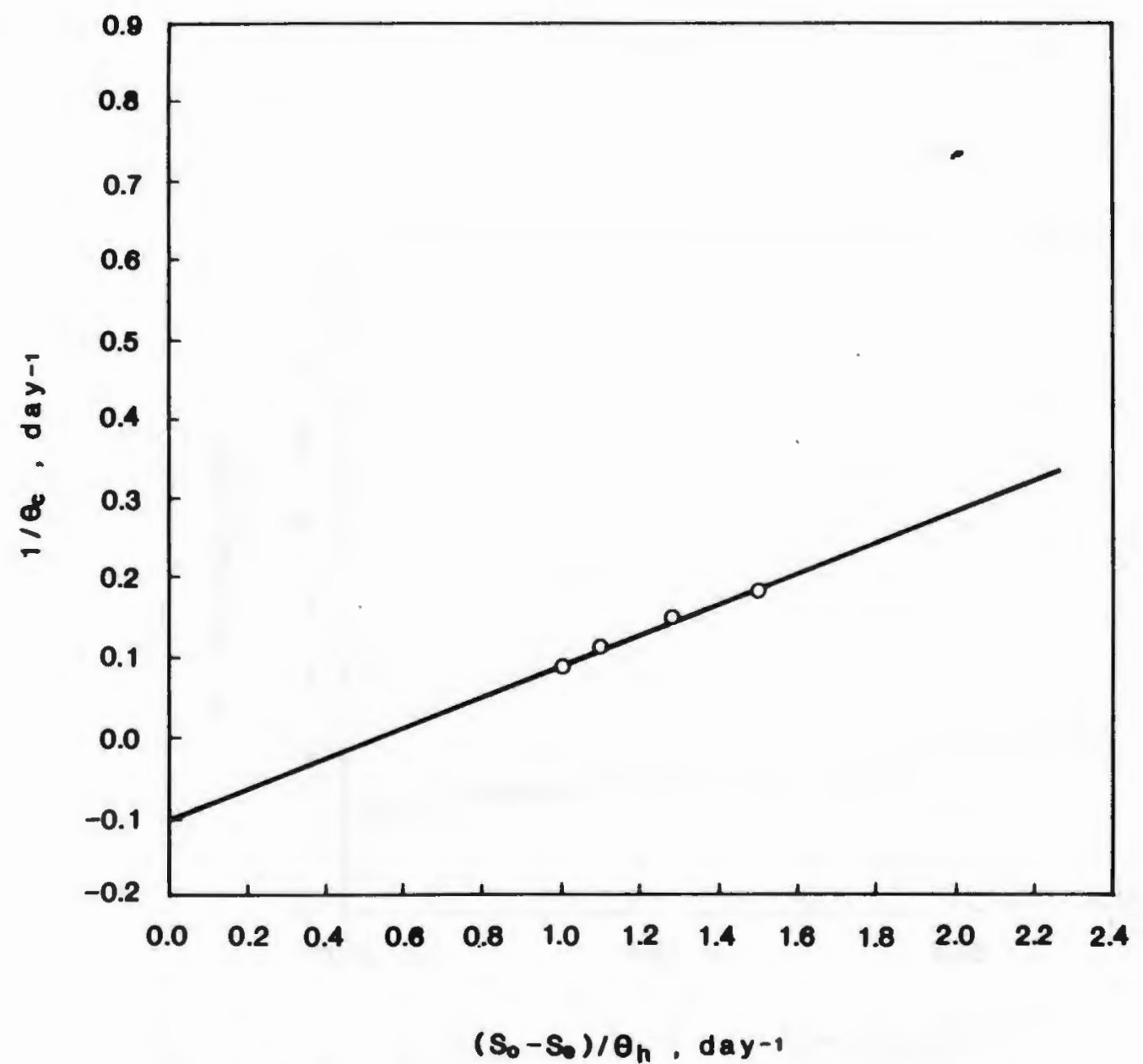

A.2.16 Bio-kinetic Constants, $P A C=50 \mathrm{mg} / \mathrm{L}, \mathrm{COD}$ 


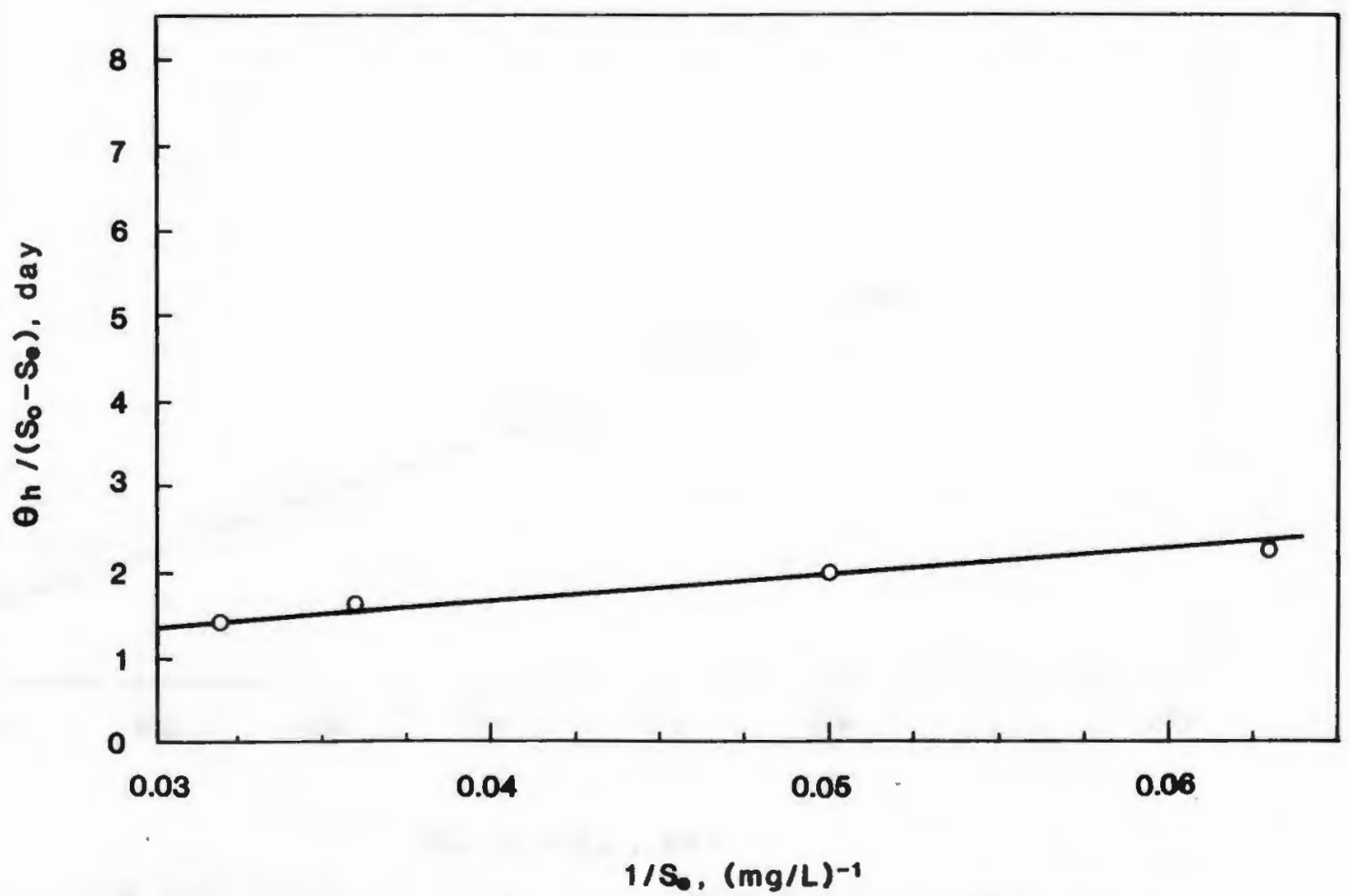

A.2.17 Bio-kinetic Constants, $P A C=50 \mathrm{mg} / \mathrm{L}, \mathrm{TOC}$ 


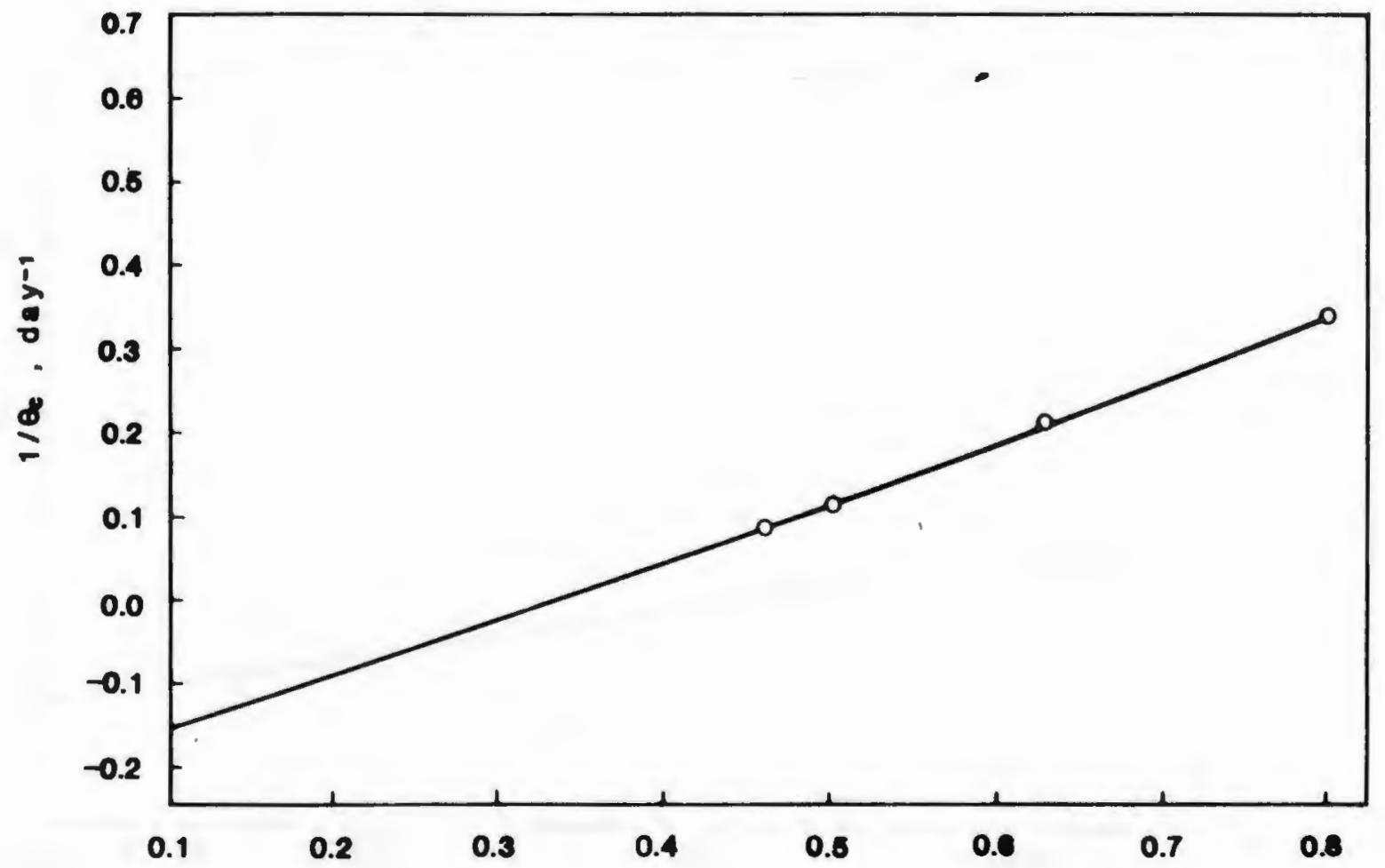

$\left(s_{b}-s_{b}\right) / \theta_{h}, d a y-1$

A.2.18 BIO-kinetic Constants, PAC $=50 \mathrm{mg} / \mathrm{L}, \mathrm{TOC}$ 


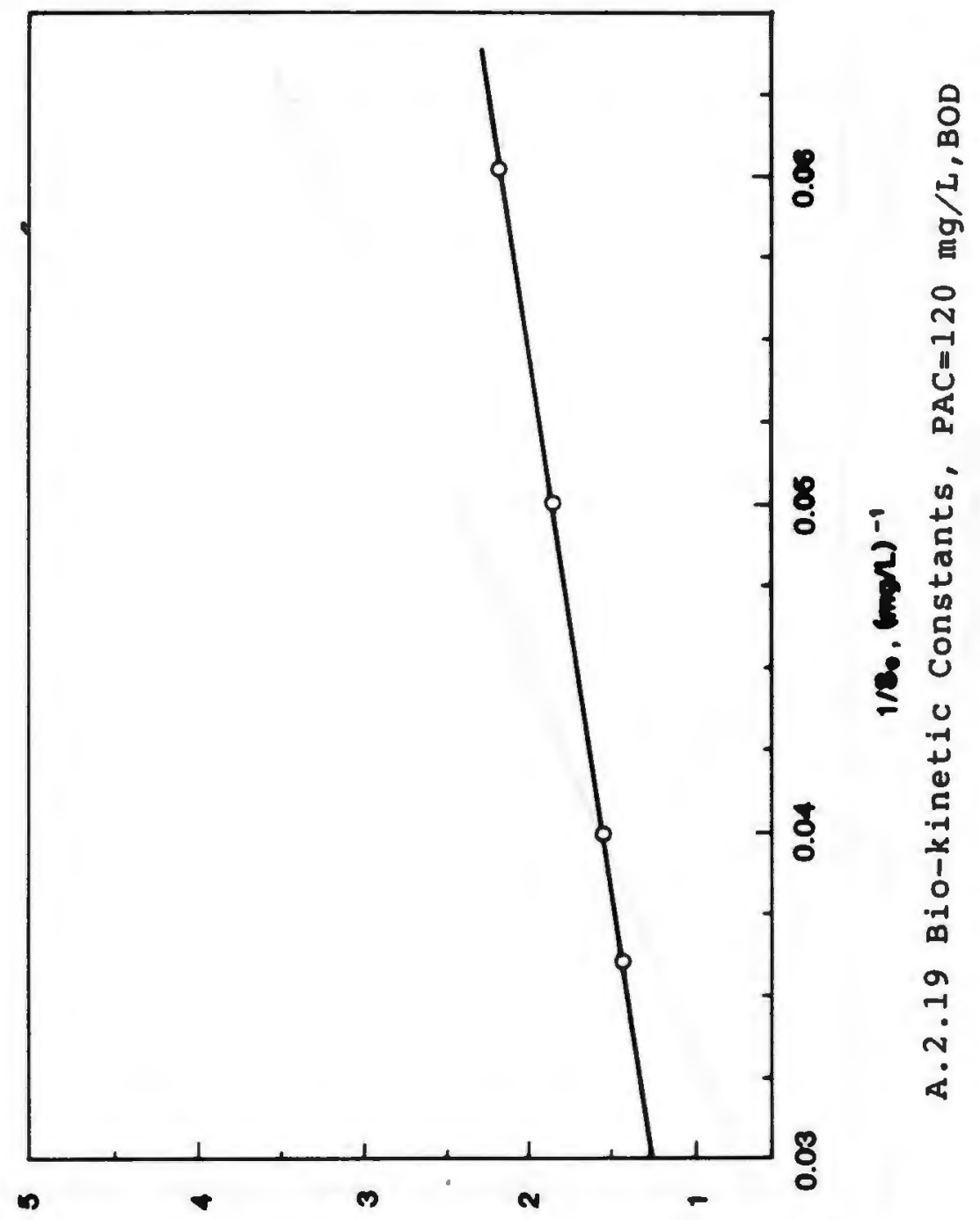

Rep $\left({ }^{\circ} s-{ }^{\circ}\right) / 4 \theta$ 


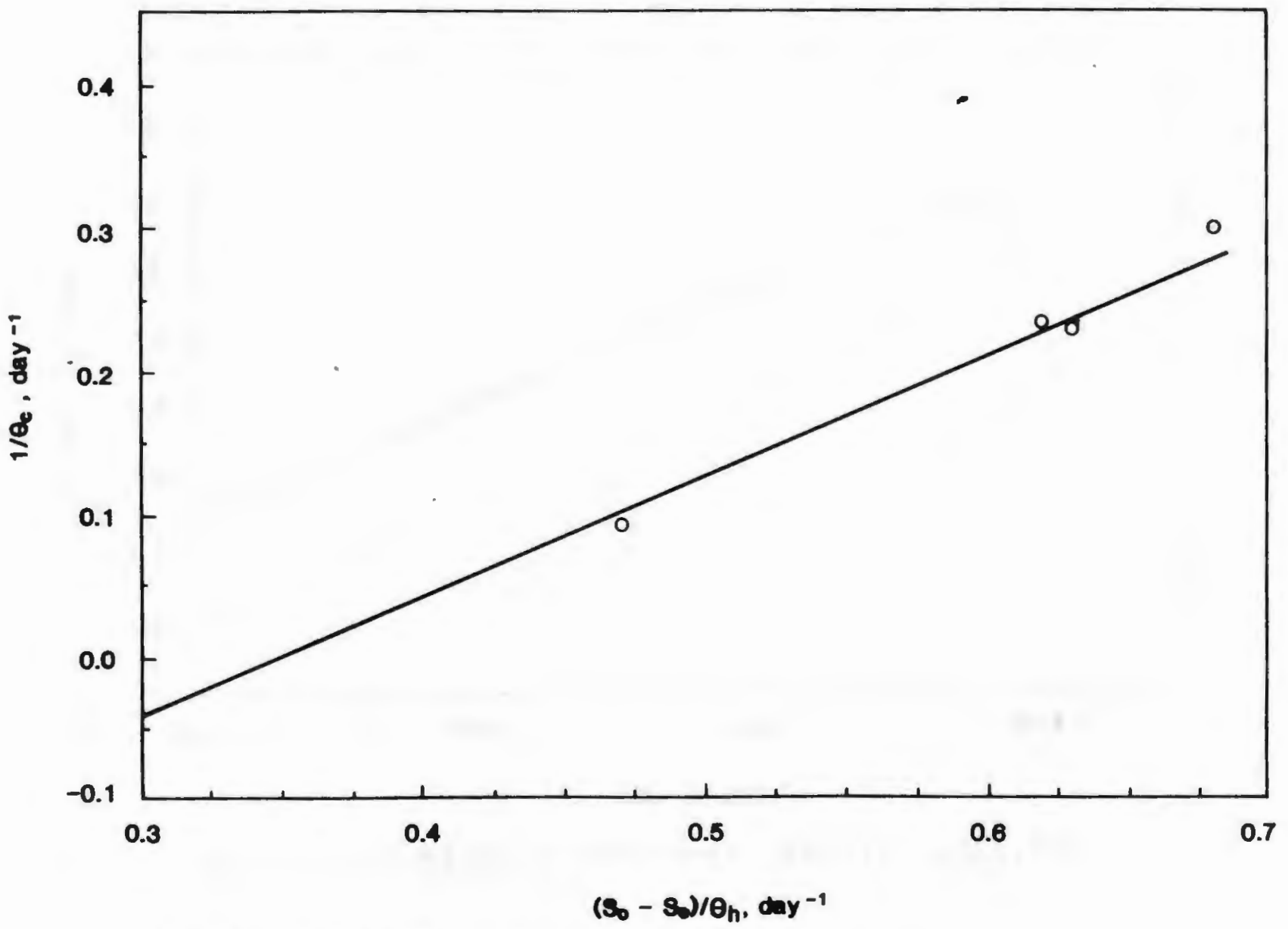

A. 2. 20 Bio-kinetic Constants, $P A C=120 \mathrm{mg} / \mathrm{L}, \mathrm{BOD}$ 


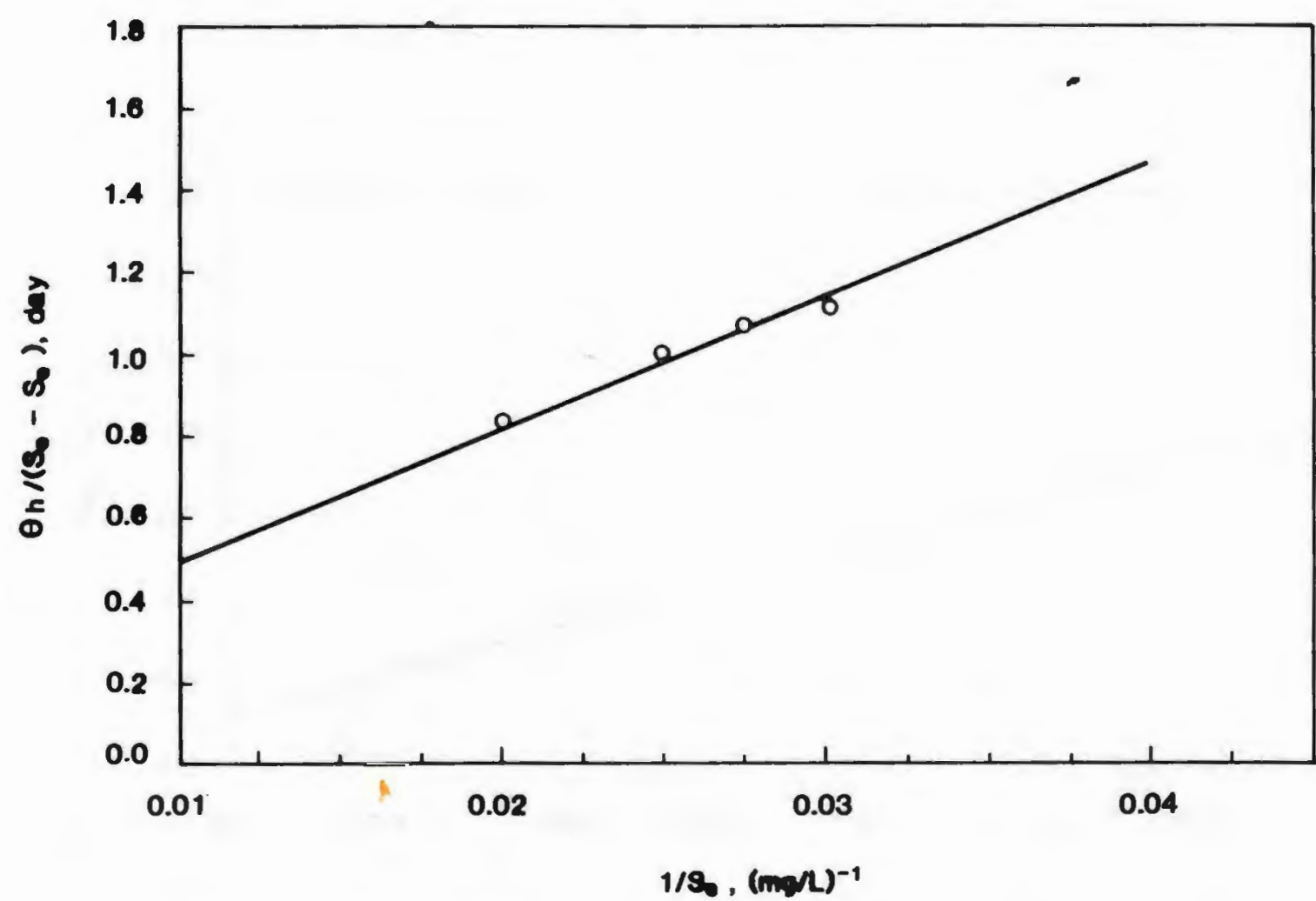

A.2.21 Bio-kinetic Constants, $P A C=120 \mathrm{mg} / \mathrm{L}, \mathrm{COD}$ 


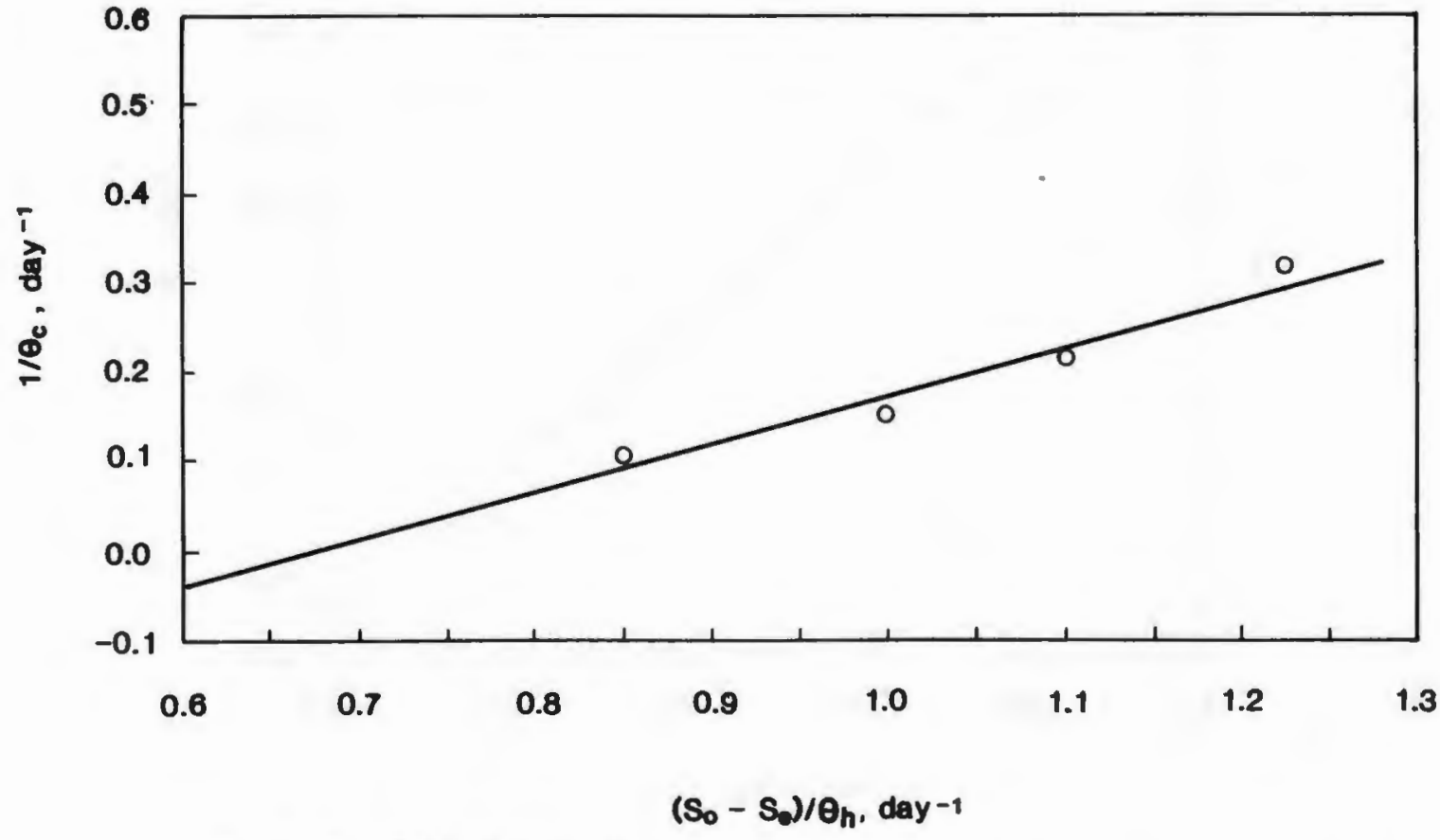

A. 2. 22 Bio-kinetic Constants, $P A C=120 \mathrm{mg} / \mathrm{L}, C O D$ 


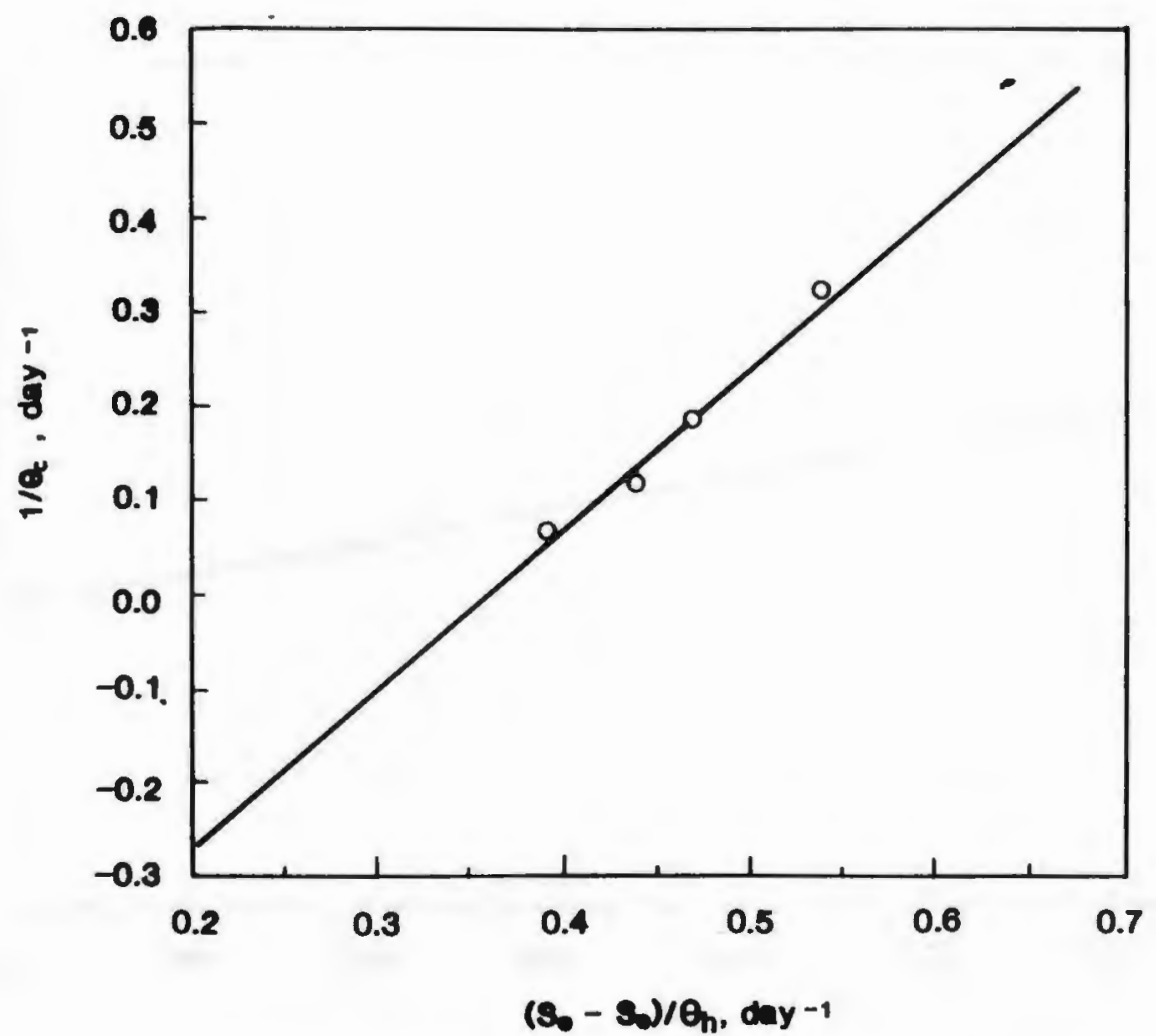

A.2.23 Bio-kinetic Constants, PAC $=120 \mathrm{mg} / \mathrm{L}, \mathrm{TOC}$ 


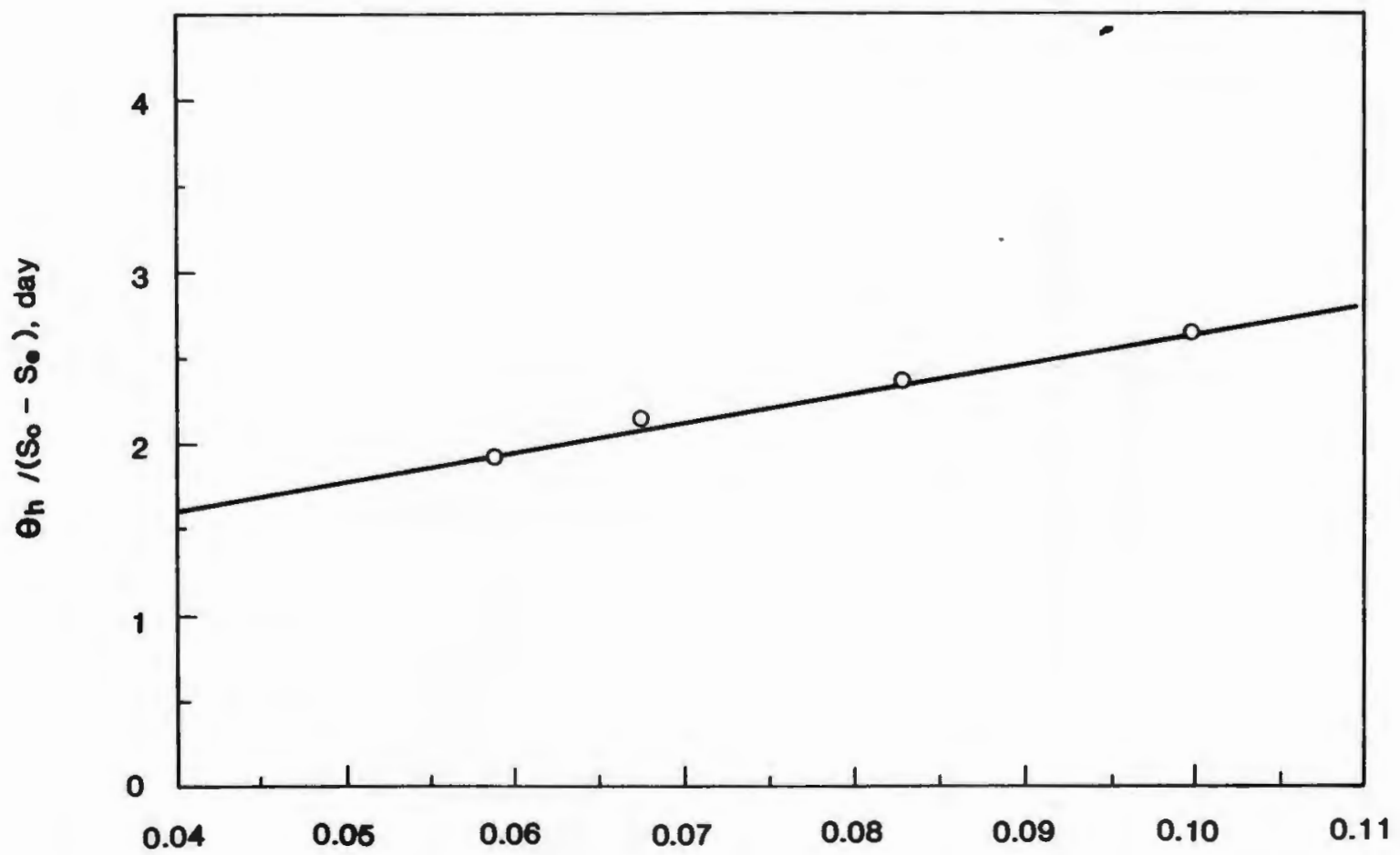

$1 / \mathrm{S}_{0},(\mathrm{mg} / \mathrm{L})^{-1}$

A.2.24 Bio-kinetic Constants, $P A C=120 \mathrm{mg} / \mathrm{L}, \mathrm{TOC}$ 


\section{Appendix 3}

Experiment 1: Figures for Priority Pollutants Removal 


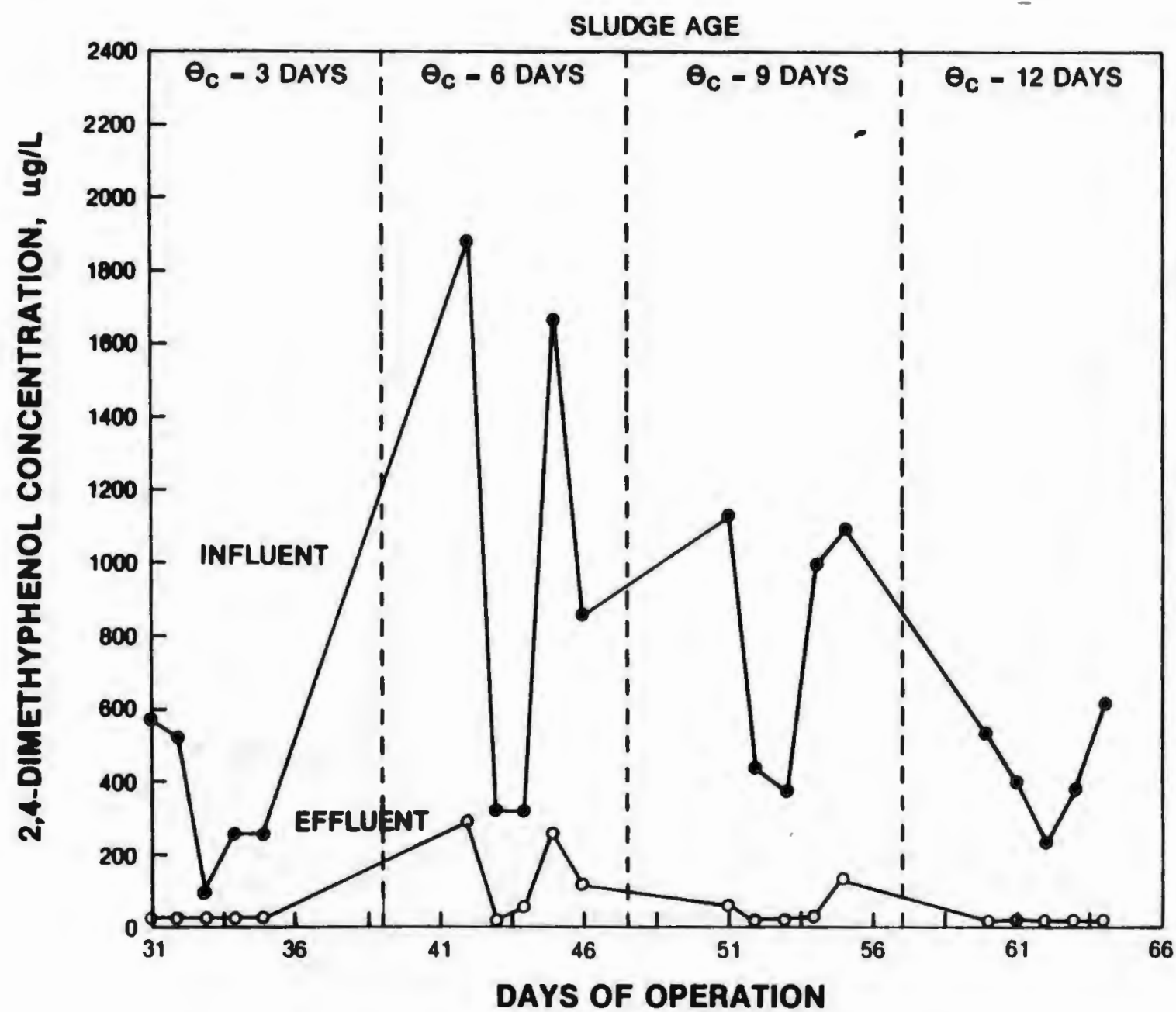

A.3.1 2,4-Dimethylphenol Removal by Activated sludge 
SLUDGE AGE

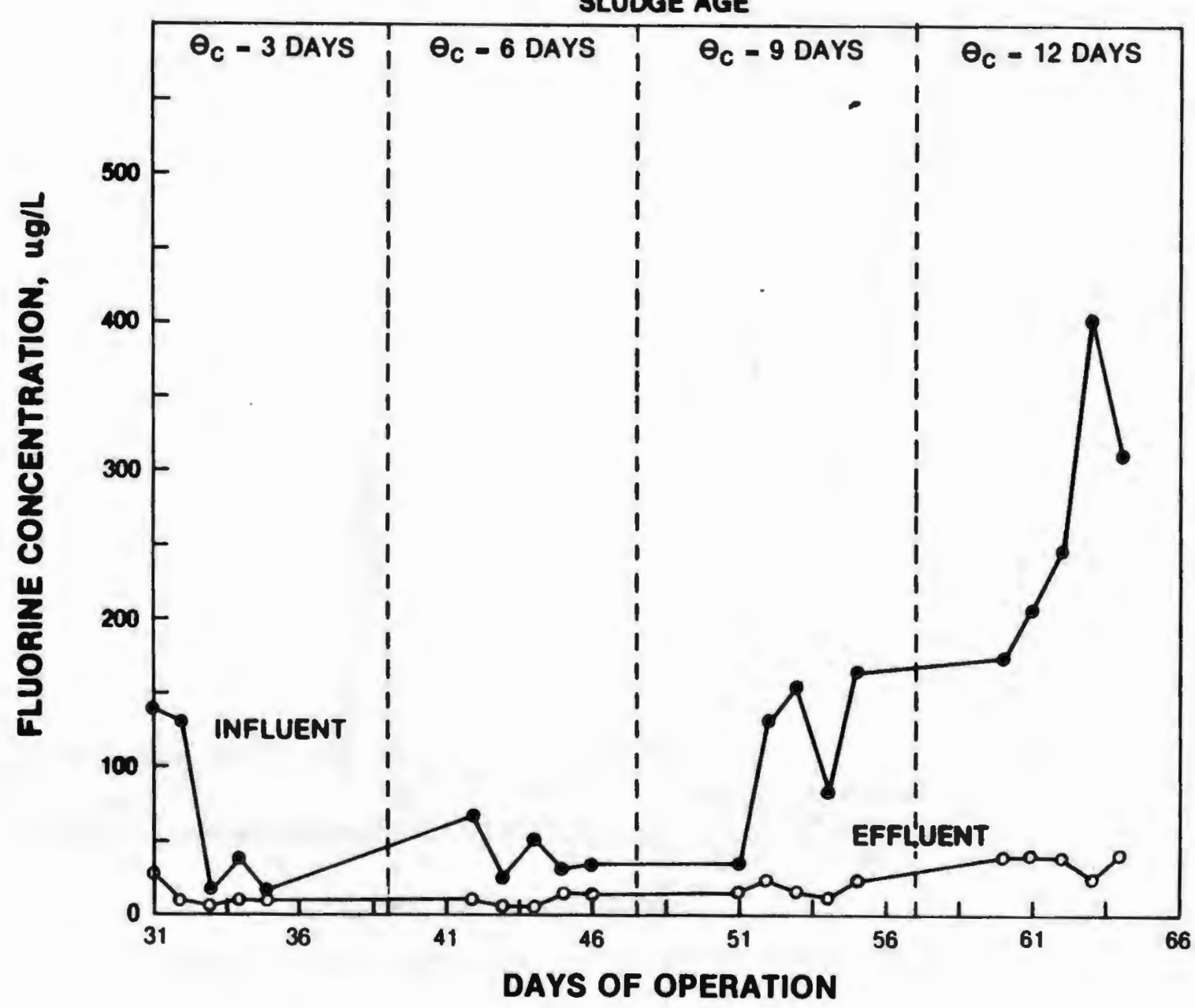

A.3.2 Fluorene Removal by Activated sludge 


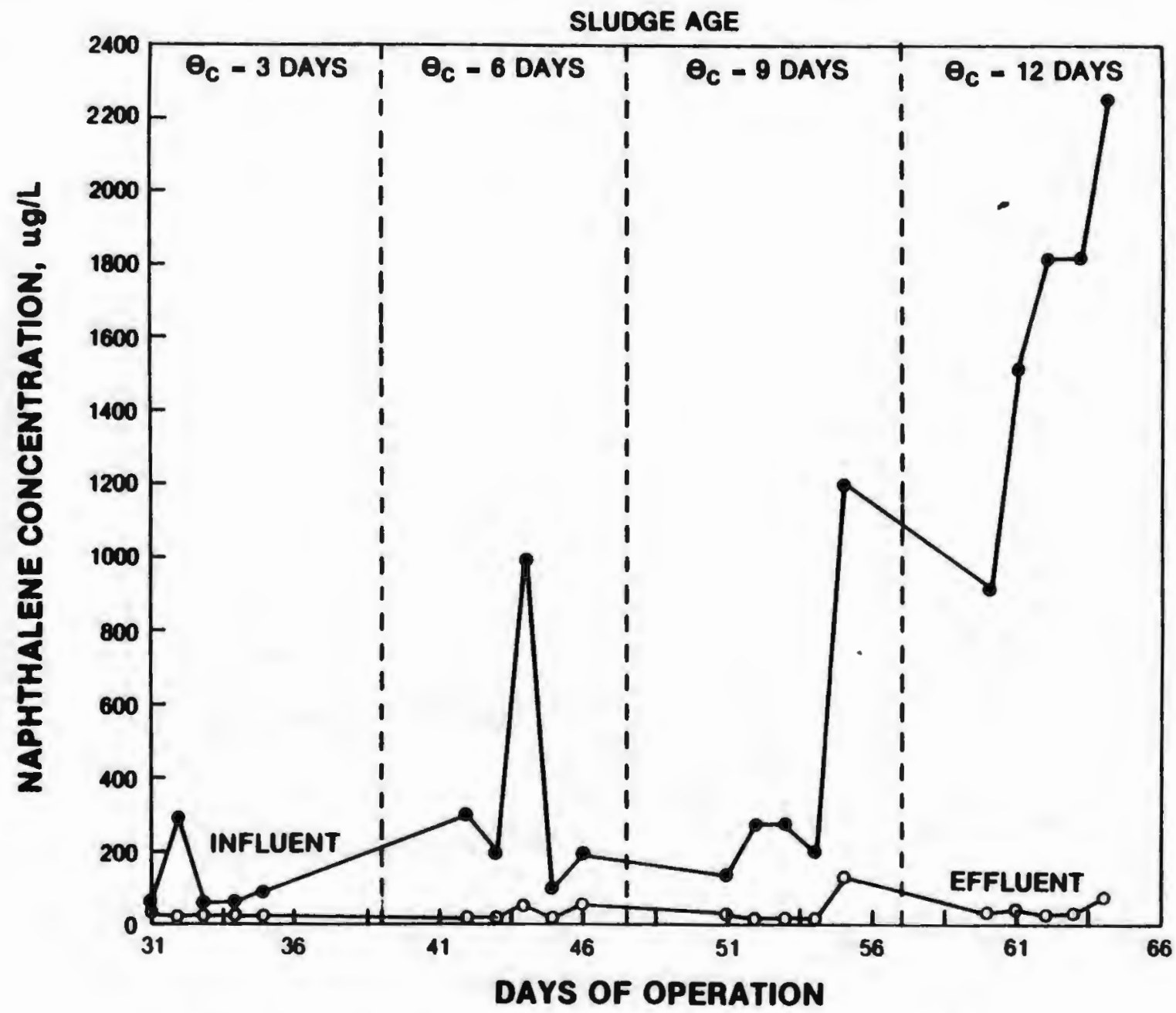

A.3.3 Naphthalene Removal by Activated Sludge 


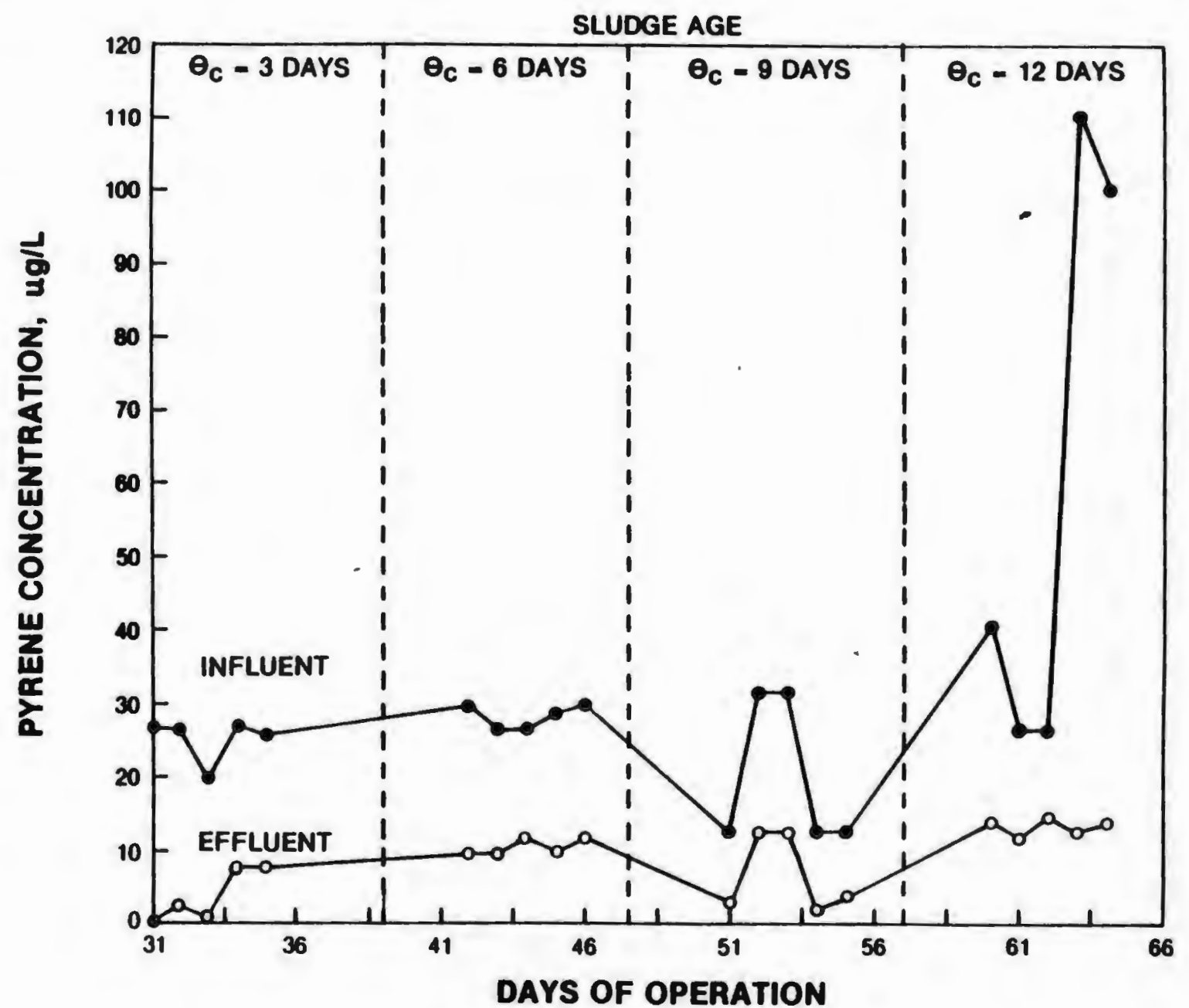

A.3.4 Pyrene Removal by Activated Sludge 
Appendix 4

Experiment 2: Figures for Priority Pollutants Removal

$P A C=10,50$, and $120 \mathrm{mg} / \mathrm{L}$

$+$ 


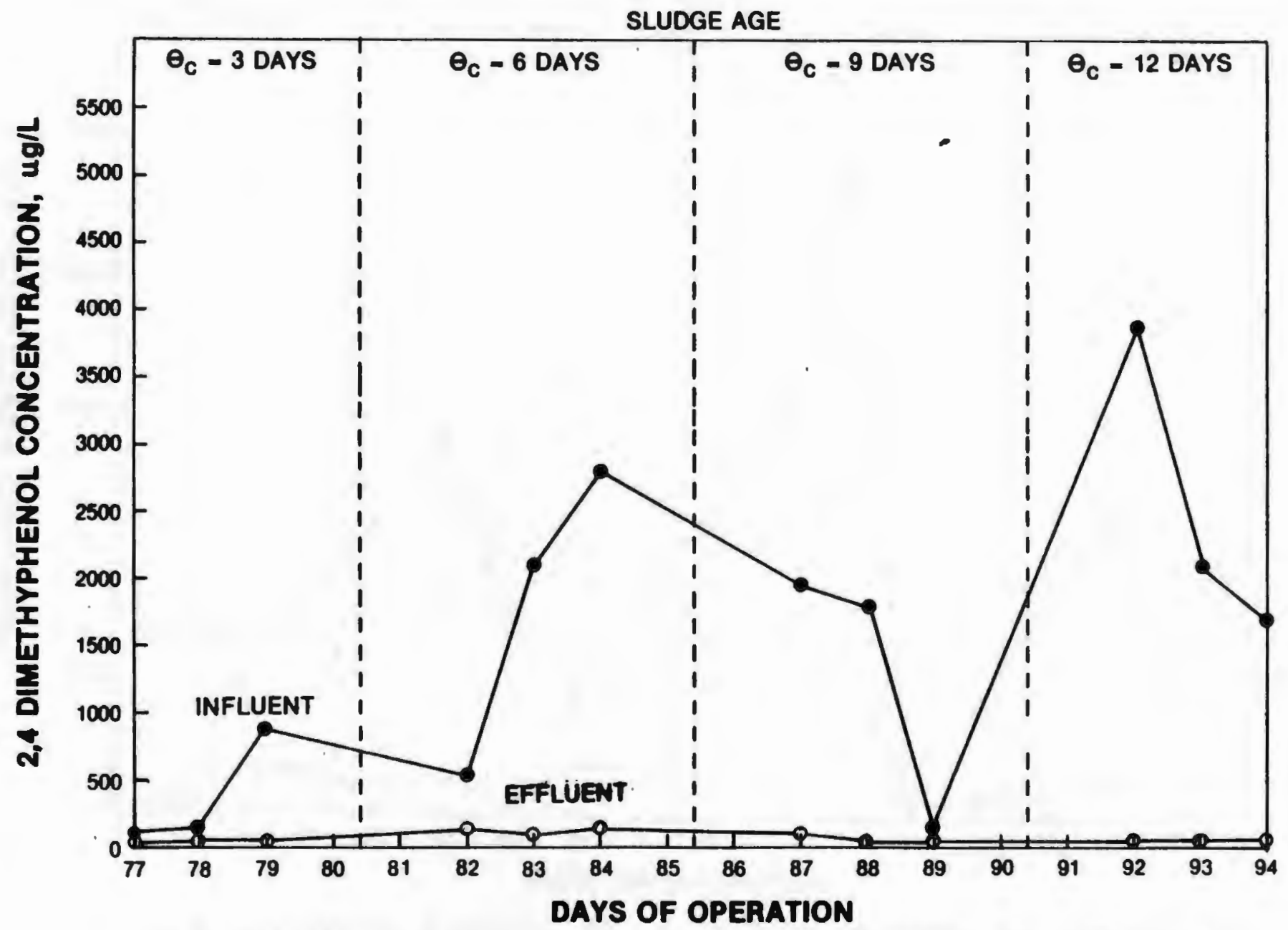

A.4.1 2,4-Dimethylphenol Removal by Activated sludge and Powdered Activated Carbon PAC $=10 \mathrm{mg} / \mathrm{L}$ 


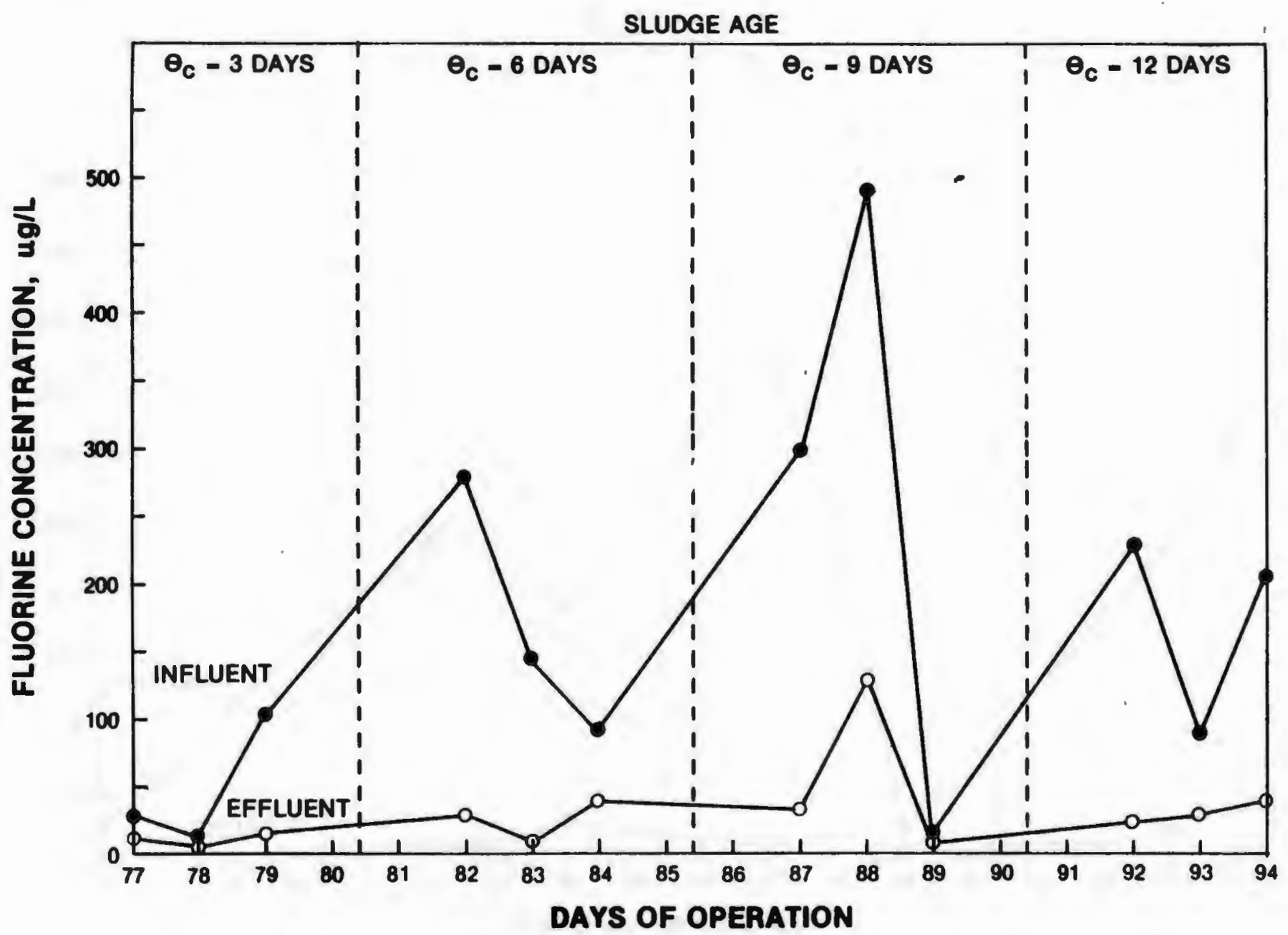

A.4.2 Fluorene Removal by Activated sludge and Powdered Activated Carbon $P A C=10 \mathrm{mg} / \mathrm{L}$ 


\section{SLUDGE AGE}

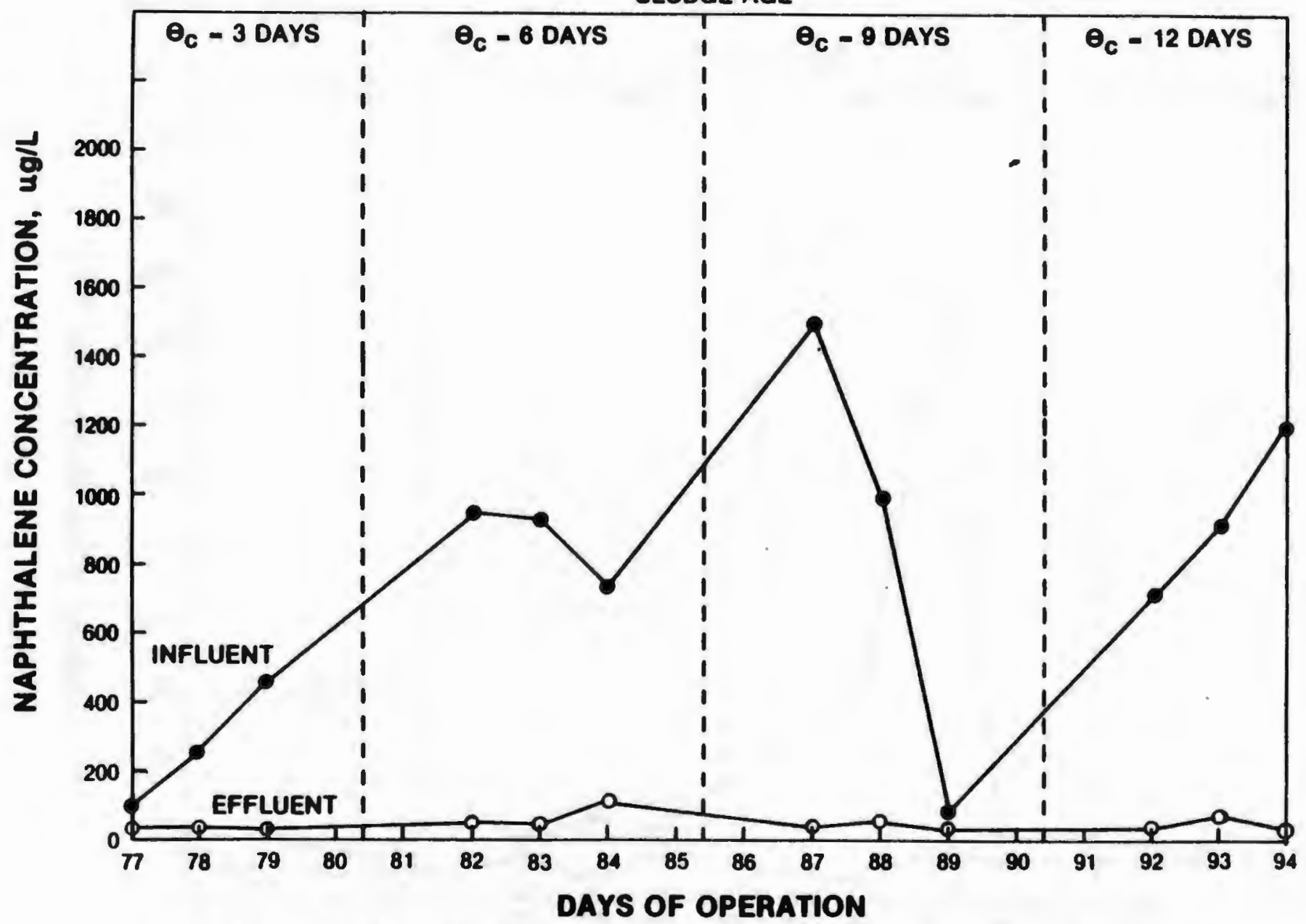

A. 4.3 Naphthalene Removal by Activated sludge and Powdered Activated Carbon $P A C=10 \mathrm{mg} / \mathrm{L}$ 


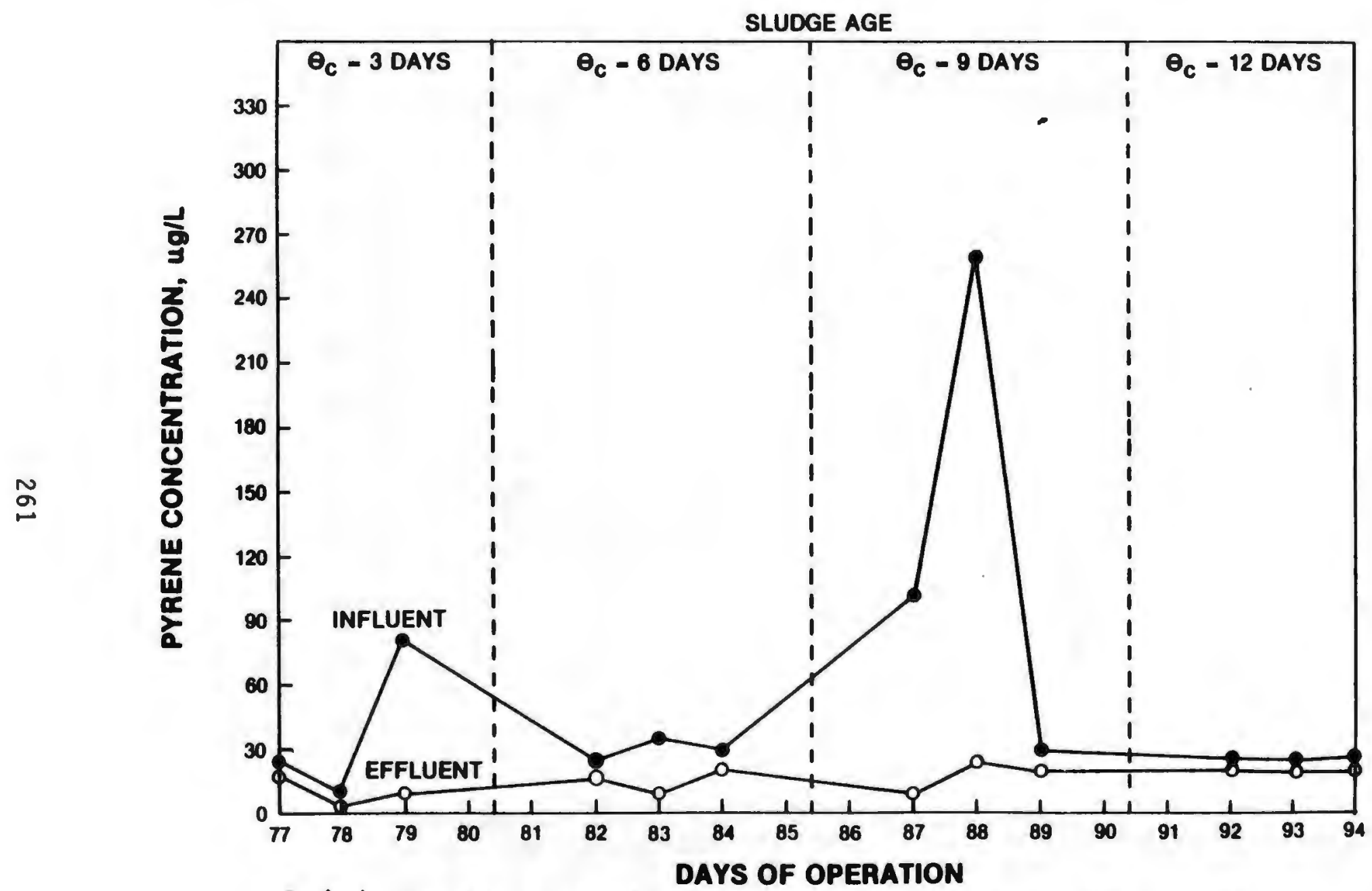

A.4.4 Pyrene Removal by Activated Sludge and Powdered Activated Carbon $P A C=10 \mathrm{mg} / \mathrm{L}$ 


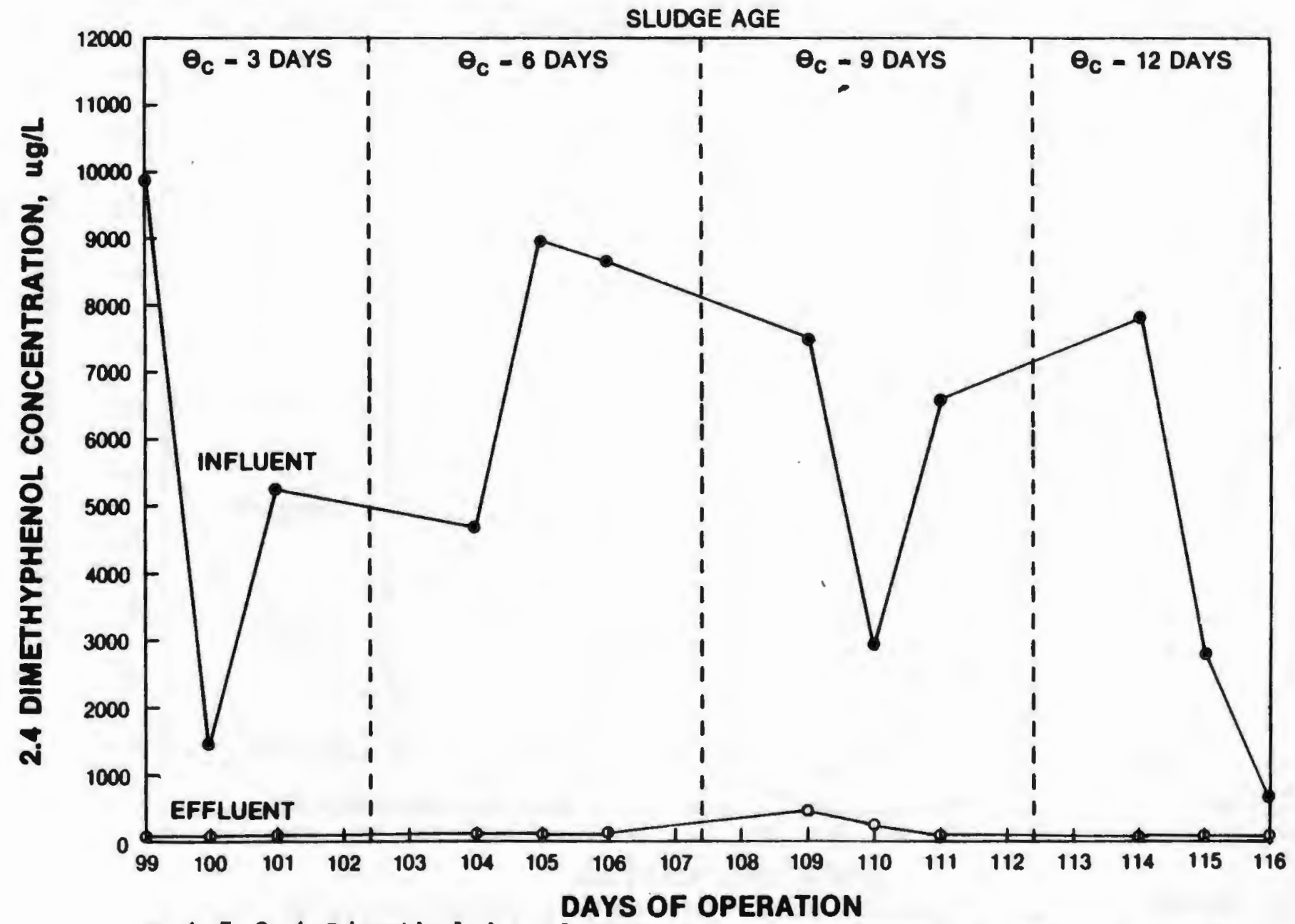

A.4.5 2,4-Dimethylphenol Removal by Activated sludge and Powdered Activated Carbon $P A C=50 \mathrm{mg} / \mathrm{L}$ 


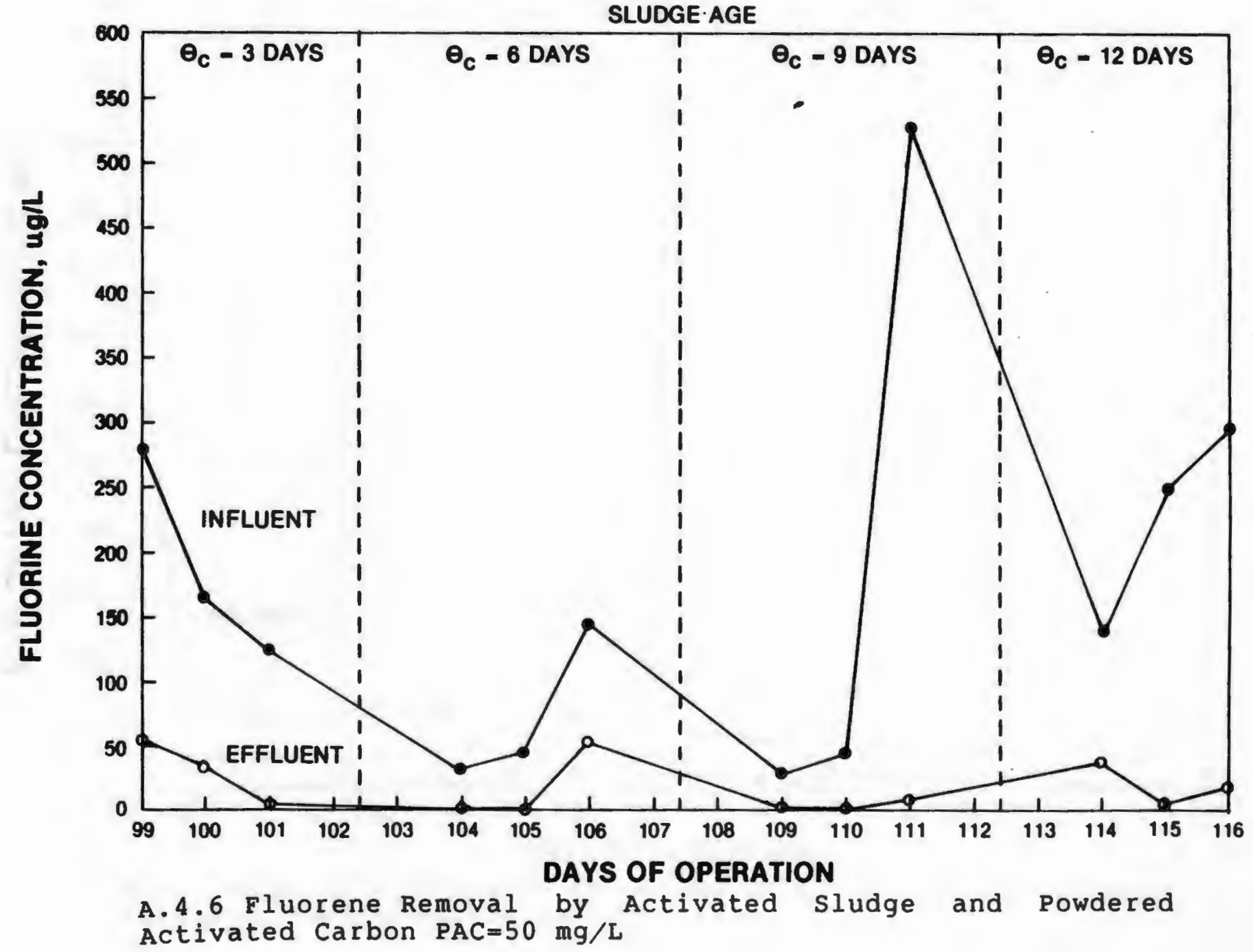




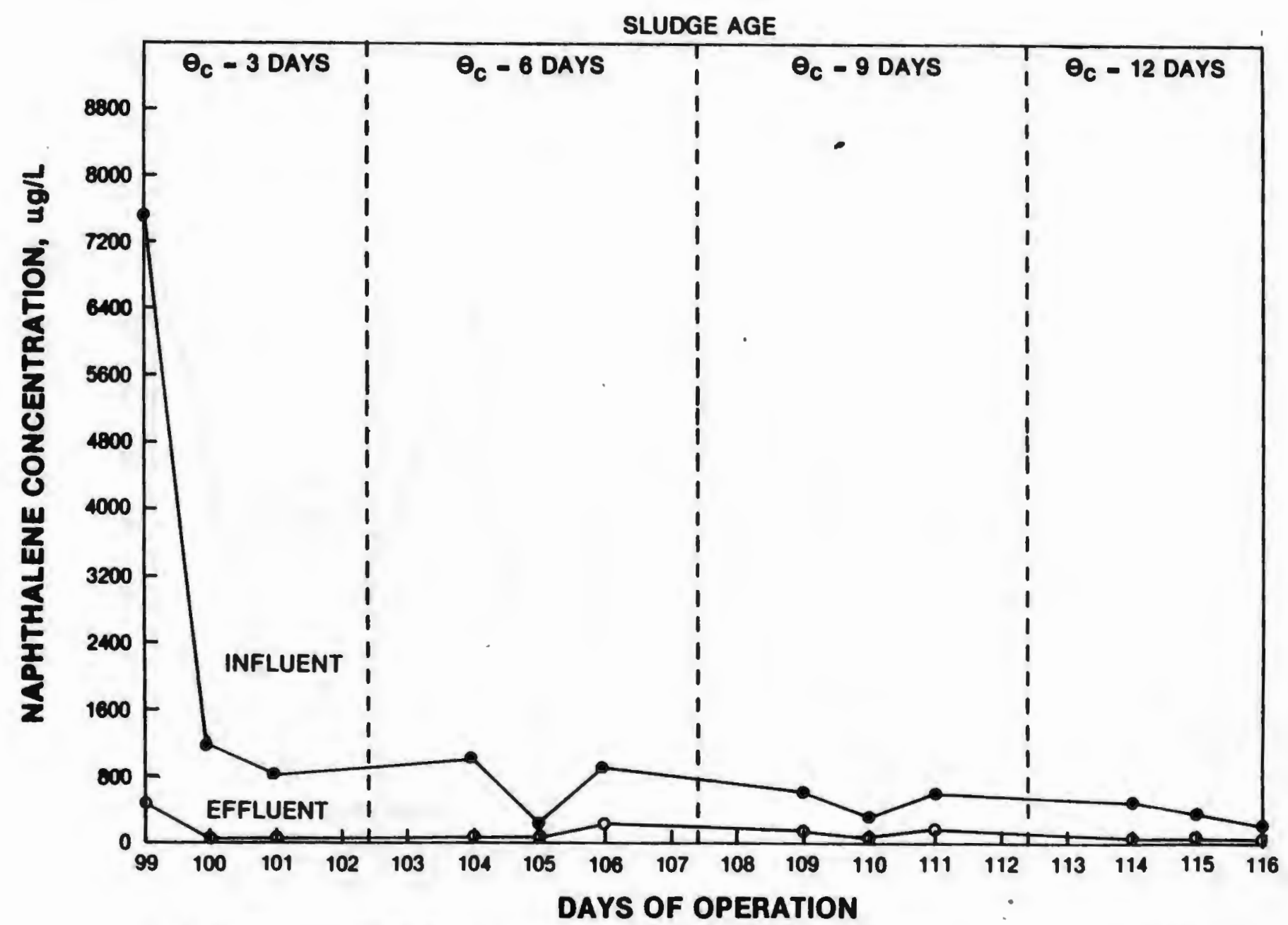

A.4.7 Naphthalene Removal by Activated Sludge and Powdered Activated Carbon $P A C=50 \mathrm{mg} / \mathrm{L}$ 


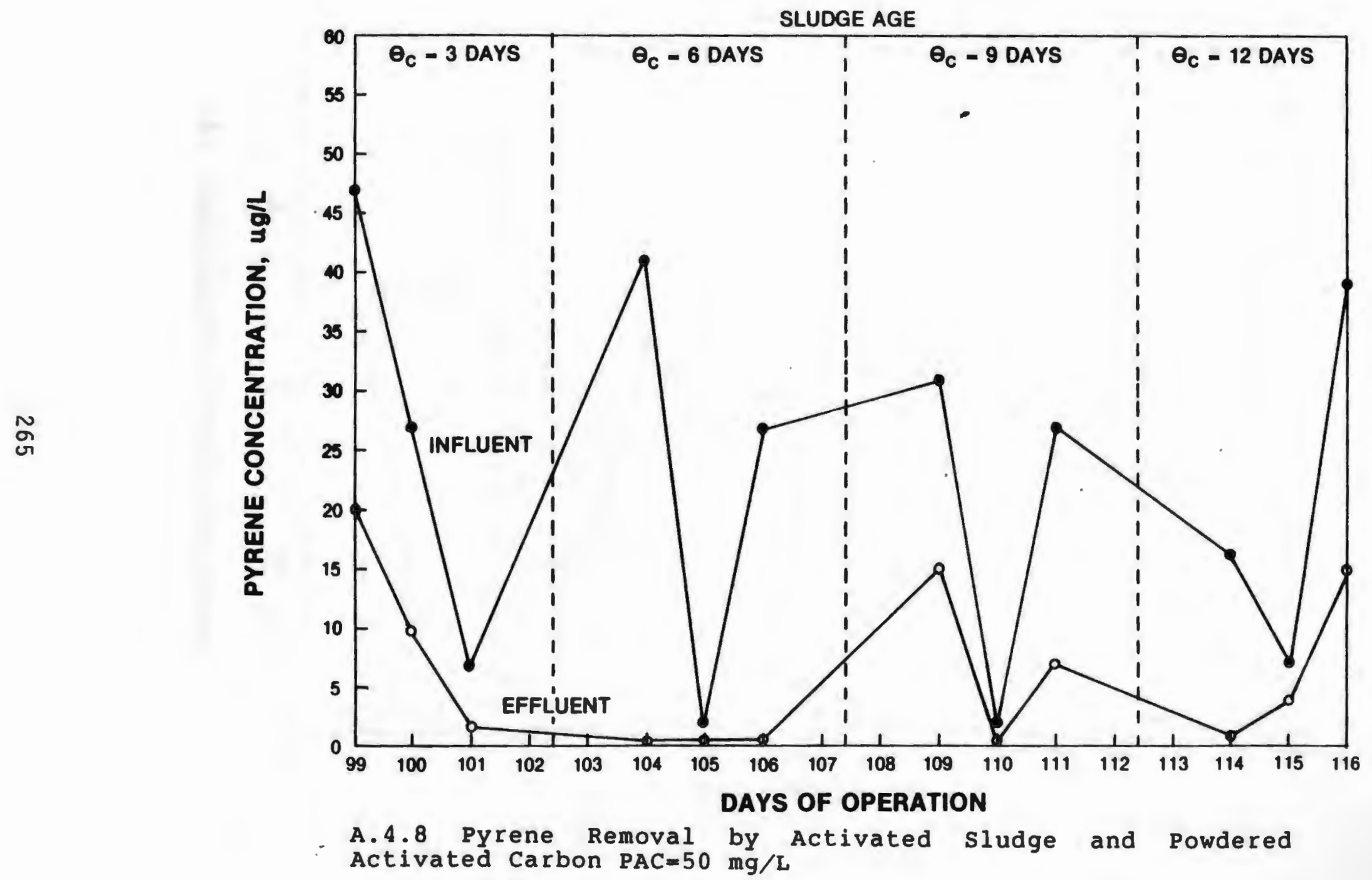




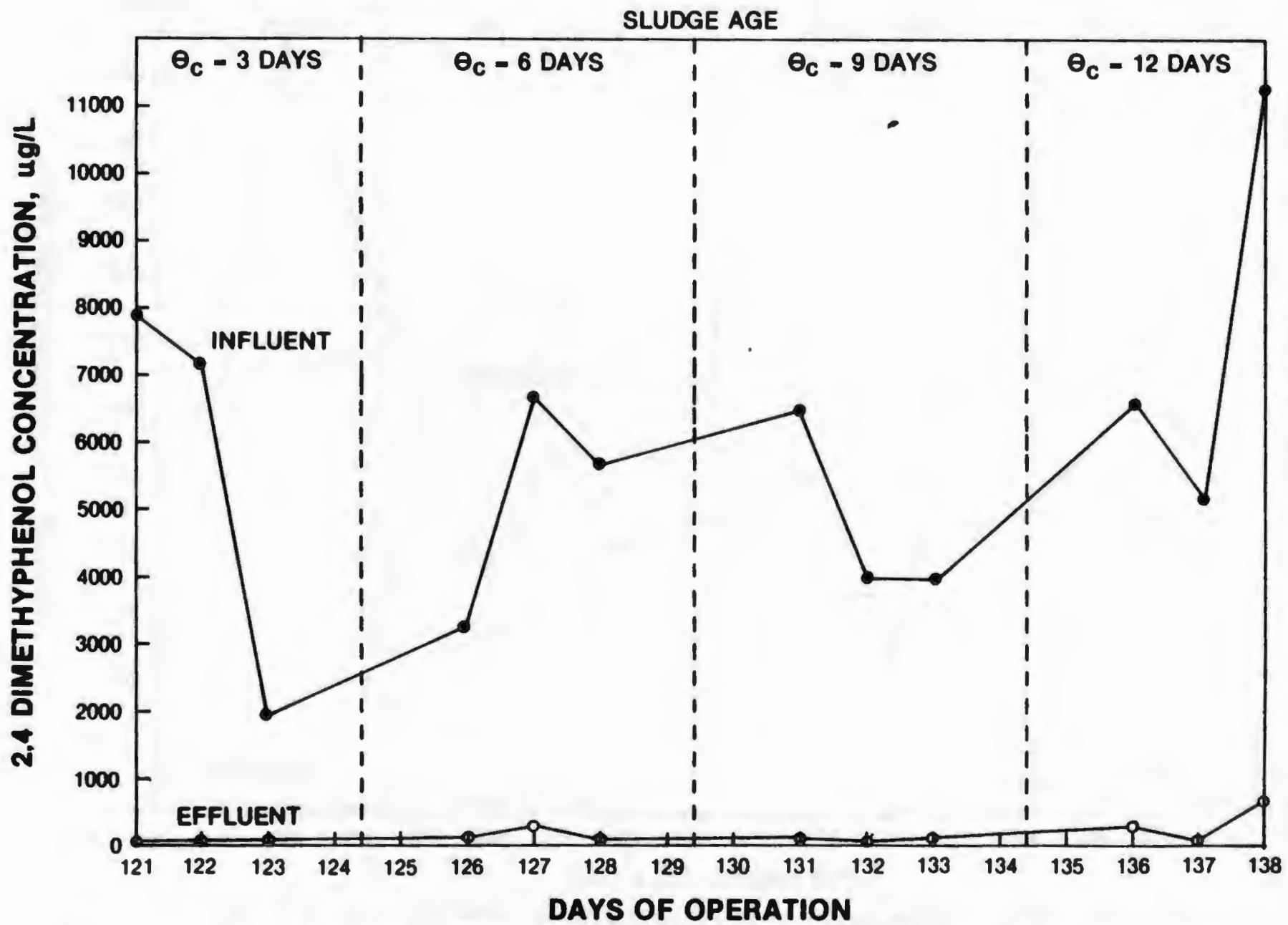

A.4.9 A.4.9 2,4-Dimethylphenol Removal by Activated sludge and Powdered Activated Carbon $P A C=120 \mathrm{mg} / \mathrm{L}$ 


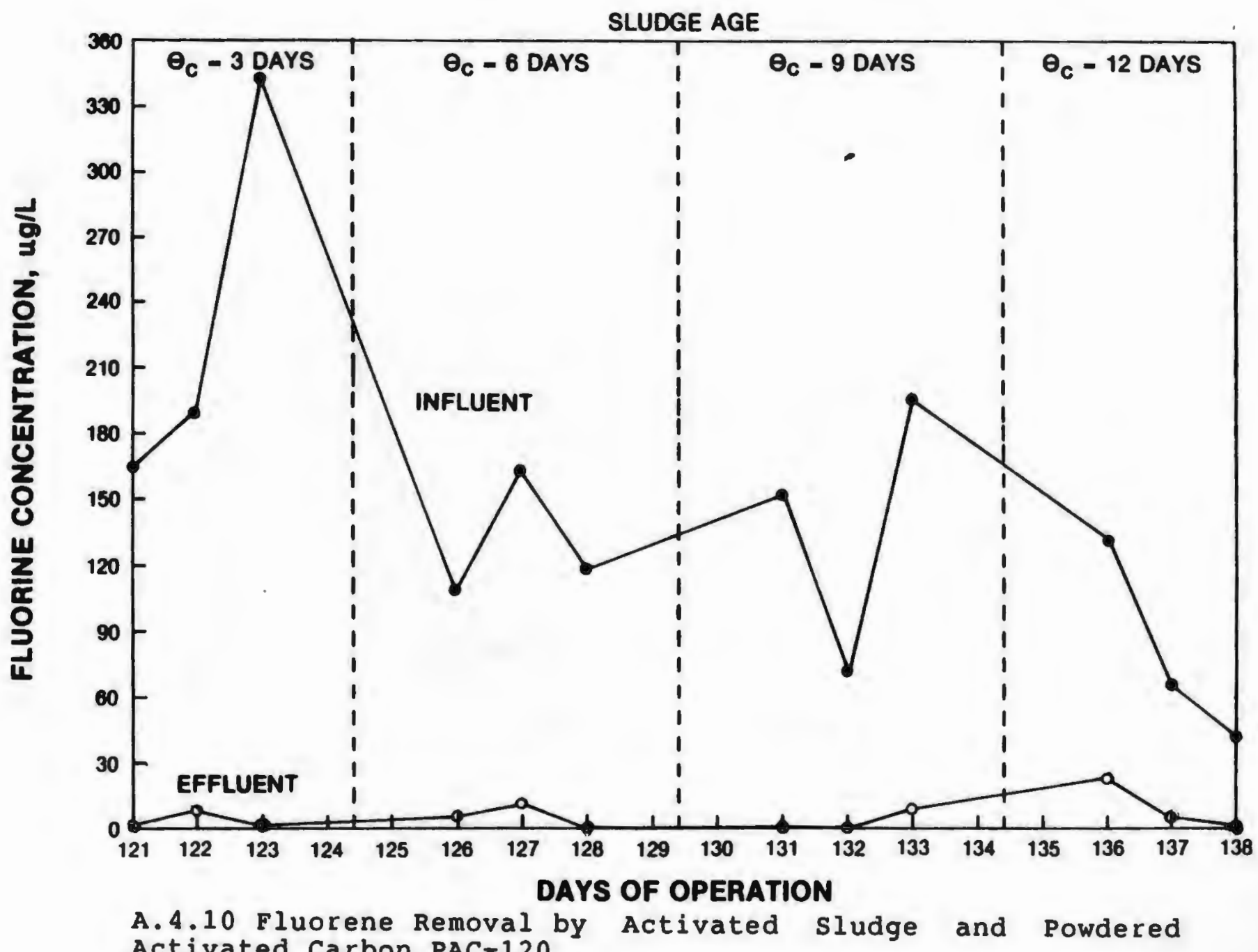




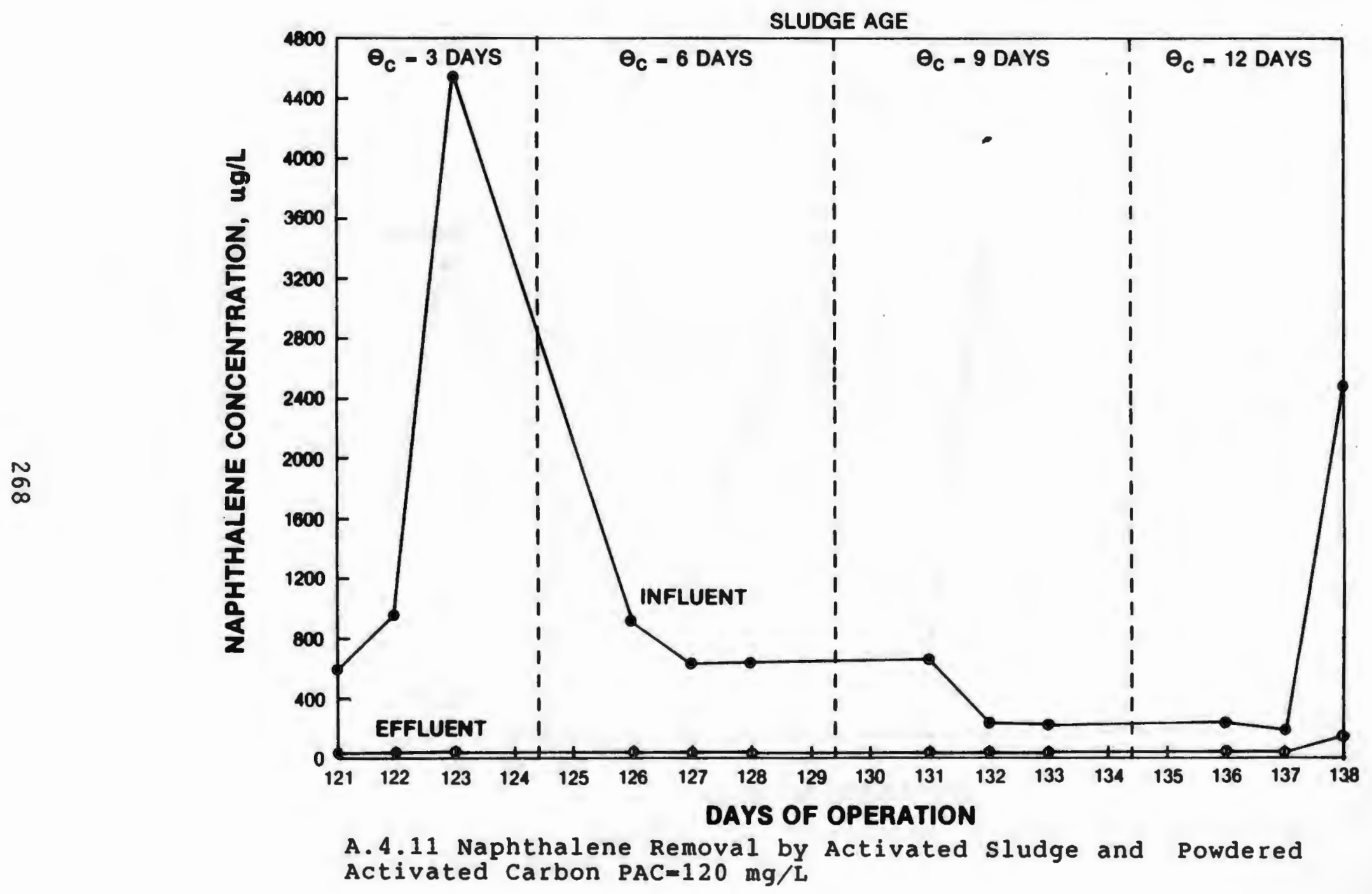




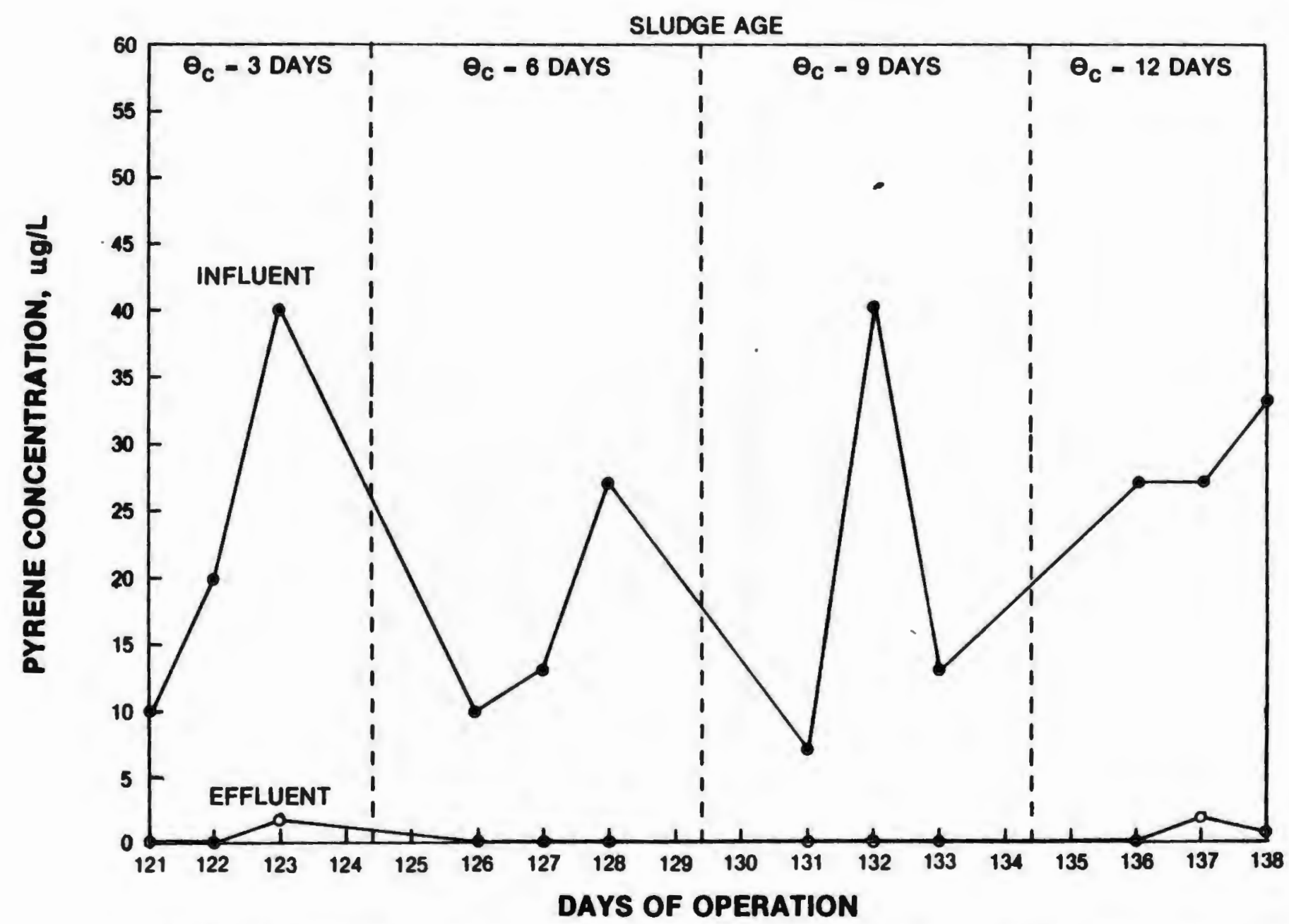

A.4.12 Pyrene Removal by Activated sludge and Powdered Activated Carbon $\mathrm{PAC}=120 \mathrm{mg} / \mathrm{L}$ 
$+$

\section{Appendix 5}

Modification of Purgeable Halocarbons Method 601 
Method for Purgeable Halocarbons

This method is a modification of the EPA Test Method No. 601 .

Compounds Determined by this Method

1. Chlor oform

Method Summary

A $5 \mathrm{ml}$ water sample is purged with helium gas at ambient temperature. Concentrations of halocarbons in water greater than $10 \mathrm{ug} / \mathrm{L}$ can be detected using gas chromatography. The halocarbons in the resulting vapor are trapped on a sorbent trap. After purging is completed, the trap is heated and backflushed with inert gas to absorb the halocarbons and transporting them to a GC column where they are separated and analyzed with a Hall detector.

\section{Apparatus and Materials}

- Tekmar LSC-2 purgeable unit

- Tracor 565 with 700A Hall Electrolytic Conductivity Detector

- GC Column - 1\% SP-1000 on Carbopack B $(60 / 80 \mathrm{mesh}), 8$ feet glass 
- Three state trap: Tenax/Silica gel/Charcoals $(12 " \times 1 / 8 ")$

- Distilled water

\section{Standard Preparation}

Stock standards are prepared at the beginning of the test. Positive confirmation for the standard was made by spiking the GC.

Each standard is prepared as follows: A $10 \mathrm{ml}$ ground glass stoppered volumetric flash is filled to about $9.8 \mathrm{ml}$ of methanol and allowed to stand unstoppered for 10 minutes before weighing to the nearest $0.1 \mathrm{mg}$. A 100 ul syringe is used to add 2-3 drops of each liquid standard to the methanol. The drops must not contact the neck of the flask. The flask is reweighed, diluted to volume. Secondary dilution of each stock of $1 / 10$ in distilled water is made. Working standards are prepared by adding 1 $\mathrm{ml}$ of the stock solution to $100 \mathrm{ml}$ of distilled water. Dilutions of secondary solution are prepared yielding standards around $10 \mathrm{ug} / \mathrm{L}$ or higher. Working standard are stored in $40 \mathrm{ml}$ teflon lined screw cap vials until used on the same day.

\section{Sampling}

Samples are collected in triplicate in $40 \mathrm{ml}$ screw cap vials with teflon lines septa. The vials are filled so 
that no headspace remains. Then, samples are refrigerated in the laboratory.

Standard and Sample Analys is

A $5 \mathrm{ml}$ syringe is filled with sample and the sample is then loaded into the Tekmar sampler. The sample is purged at room temperature for 15 minutes with helium at $40 \mathrm{ml} / \mathrm{min}$, then desorbed at $200^{\circ} \mathrm{C}$ for 4 minutes with helium at $30 \mathrm{ml} / \mathrm{min}$. The trap is baked at $180^{\circ} \mathrm{C}$ for 7 minutes. The GC conditions for HALL are the following:
Initial temperature
$45^{\circ} \mathrm{C}$
Final temperature
$200^{\circ} \mathrm{C}$
Program rate
$8^{\circ} \mathrm{C} / \mathrm{min}$
Initial hold
3 min.
Detector temperature
$200^{\circ} \mathrm{C}$
Injection temperature
$200^{\circ} \mathrm{C}$
Final hold
$15 \mathrm{~min}$.
Carrier gas, He
$40 \mathrm{ml} / \mathrm{min}$
Reaction gas, $\mathrm{H}_{2}$
$50 \mathrm{ml} / \mathrm{min}$

\section{External Standard Quantitation}

Compounds are quantitated by comparing sample peak areas and standard peak areas. Peaks are identified by retention time. 


\section{Quality Control}

1. A method blank is run every day to make the system is free of interferences.

2. Standards are run for Retention Times to evaluate laboratory data quality.

3. EPA quality Control Check Samples are run to insure the accuracy of our analytical system. 
$+$

Appendix 6

Modification of volatile

Aromatics Method 602 
Method for Volatile Aromatics

This method is a modification of the EPA Test Method No. 602 .

Compound Determined by this Method

1. Benzene

2. Ethylbenzene

3. Toluéne

4. $M-x y l$ ene

5. $0-x y l$ ene

Method Summary

A $5 \mathrm{~mL}$ water sample is purged with helium at ambient temperature. The aromatics in the resulting vapor are trapped on a sorbent trap. The trap was rapidly heated and backflushed, desorbing the aromatics and transporting them to a GC column where the were separated and analyzed with a PID. Concentrations of volatile aromatics in wastewater greater than $10 \mathrm{ug} / \mathrm{L}$ can be detected at ambient temperature. Initially positive samples were confirmed by GC/MS. Positive confirmation for sample was made by spiking the GC as well. 


\section{Apparatus and Materials}

- Tekmar Model LSC-2

- Tracor Model No. 565 with Photoionization Detector (PID)

- GC Column - 1\% SP-1000 on Carbopack B $(60 / 80$ mesh $), 8$ feet glass

- Three state trap: Tenax/Silica gel/Charcoals (12" X 1/8")

- Organic Free water

Standard Preparation

stock standards are prepared. A $10 \mathrm{ml}$ ground glassstoppered volumetric flask is filled with $9.8 \mathrm{ml}$ of methanol and allowed to stand unstoppered for 10 minutes or until all alcohol wetted surfaces have dried before weighing to the nearest $0.1 \mathrm{mg}$. A 100 ul syringe is used to add 3 drops of each liquid standard to the methanol. The drops must not contact the neck of the flask. The flask is re-weighed, diluted to volume, stoppered and mixed by inverting the flask several times. The concentration calculated in ug/ul or in $\mathrm{gm} / \mathrm{ml}$. Stock standard solutions transferred into a Teflon-sealed screwcap bottle and stored in the freezer. A secondary dilution of stock solution is prepared. Dilution standards are prepared by adding 1000 ul of stock solution to $100 \mathrm{ml}$ of distilled water. Working standards are prepared and stored in a $100 \mathrm{ml}$ or in a $50 \mathrm{ml}$ flask until used on the same day. 
Sampling

Samples are collected in triplicate in $40 \mathrm{ml}$ screw cap vials with teflon lined septa. The vials are filled so that no headspace remains.

Standard and Sample Analysis

$5 \mathrm{ml}$ syringe is filled with sample and then loaded into the Tekmar sampler. The sample is purged at room temperature for 15 minutes with helium at $40 \mathrm{ml} / \mathrm{min}$., then desorbed $200^{\circ} \mathrm{C}$ for 4 minutes with helium at $40 \mathrm{ml} / \mathrm{min}$. Then the trap is baked at $180^{\circ} \mathrm{C}$ for 7 minutes. The sampler is rinsed with distilled water. The GC conditions for PID are the following:

Initial temperature

Final temperature

Program rate

Initial hold

Detector temperature

Injection temperature

Final hold

Carrier gas, He

Detector

$$
\begin{aligned}
& 45^{\circ} \mathrm{C} \\
& 200^{\circ} \mathrm{C} \\
& 8{ }^{\circ} \mathrm{C} / \mathrm{min} \\
& 3 \mathrm{~min} . \\
& 250^{\circ} \mathrm{C} \\
& 200^{\circ} \mathrm{C} \\
& 15 \mathrm{~min} . \\
& 40 \mathrm{ml} / \mathrm{min} \\
& \text { PID }
\end{aligned}
$$


Peaks are identified by retention time. Compounds are quantified by comparing peak area and daily run standard peak areas. All sample ( > $10 \mathrm{ug} / \mathrm{L})$ are identified and their concentrations are determined and recorded.

\section{Quality Control}

1. A method blank is run every day to make sure that the system is free of interferences.

2. Standards are run for retention times to allow detection of any potential problems.

3. EPA quality control check samples are run to insure the accuracy of our analytical system. 


\section{Appendix 7}

Water Analysis in the Shuaiba Industrial Area 
Analysis of Cooling Seawater at the Shuaiba Industrial Area. (Source: Ref. No. 59).

Neutral Electrical Conductivity micromhos at $20^{\circ} \mathrm{C}$ Total Dissolved Solids (TDS), ppm $\mathrm{pH}$ Free Causticity, "ppm as $\mathrm{NaOH}$
Total "

Total Alkalinity, ppm as $\mathrm{CaCO}_{3}$

Total Chlorides, ppm as $\mathrm{CL}$

Total Sulphątes, ppm as $\mathrm{SO}_{4}$

Total Hardness, ppm as $\mathrm{CaCO}_{3}$

Peranent Hardness, ppm as $\mathrm{CaCO}_{3}$

Temporary Hardness, ppm as $\mathrm{CaCO}_{3}$

Calcium Hardness, ppm as $\mathrm{Ca}++$

Magnesium Hardness, ppm as Mg++

Total Free and Combined Ammoniacal

Nitrogen, ppm $\mathrm{NH}_{3}$

Total Silica Soluble and

Suspended, ppm as $\mathrm{SiO}_{2}$

Phosphate, $\mathrm{ppm}$ as $\mathrm{PO}_{4}$

Chlorine, ppm as $\mathrm{CL}_{2}$

(after Chlorination)

Total Iron, ppm as $\mathrm{Fe}+3$

Sodium, ppm as $\mathrm{Na}^{+}$

Critical Temperature of Cooling

seawater, ${ }^{C}$

Free Carbon Dioxide, ppm $\mathrm{CO}_{2}$

$$
\begin{gathered}
70,000-72,500 \\
44,400-45,985 \\
8.6-9.0 \\
\text { Ni } 1 \\
\text { Less than } 5 \\
130-140 \\
21,500-22,630 \\
3,100-3,300 \\
8,400-8,500 \\
8,300-8,400 \\
100-500 \\
500-500 \\
1,740-1,760 \\
0.5-10.0 \\
5-50 \\
- \\
2.5
\end{gathered}
$$

\section{5}

32 
Drinking Water Analysis, Shuaiba Power and

Water production Plants. (Source: Ref. No. 59).

Parameter

$\mathrm{pH}$

TOS

Chloride

Sulphate

Total Hardness

Total Iron

Residual Chlorine

Fluoride

Conductivity
Concentration

$$
7-8.5
$$

$500 \mathrm{mg} / \mathrm{L}$

$150-200 \mathrm{mg} / \mathrm{L}$

$200-280 \mathrm{mg} / \mathrm{L}$

$100-120 \mathrm{mg} / \mathrm{L}$ as $\mathrm{CaCO}_{3}$

$0.01-0.30 \mathrm{mg} / \mathrm{L}$

$0.5 \mathrm{mg} / \mathrm{L}$

$0.7-1 \mathrm{mg} / \mathrm{L}$

700-850 micromhos/cm 
Analysis of Distilled Water Production By Shuaiba Power and Water Production Plants (Source: Ref. No. 59).

\begin{tabular}{|c|c|c|}
\hline Par ameter & \multicolumn{2}{|c|}{ Concentrations (ppm) } \\
\hline $\begin{array}{l}\text { Neutral Electrical Conductivity } \\
\text { in micromhos at } 20^{\circ} \mathrm{C}\end{array}$ & 5.0 & 50.0 \\
\hline $\begin{array}{l}\text { Calculated Total Dissolved Solids } \\
\text { (TDS) (Based on } 0.60 \mathrm{ppm} / \text { umhos) }\end{array}$ & 3.0 & 30.0 \\
\hline $\mathrm{pH}$ & $6.8-7.0$ & 9.0 \\
\hline Free Causticity as $\mathrm{NaOH}$ & ND & ND \\
\hline Total Causticity as $\mathrm{NaOH}$ & ND & 4.0 \\
\hline Total Chloride as $\mathrm{Cl}^{-}$ & 2.0 & 20.0 \\
\hline Total Alkalinity as $\mathrm{CaCO}_{3}$ & Trace & 10.0 \\
\hline Total Sulphate as $\mathrm{SO}_{4}$ & $"$ & 5.0 \\
\hline Total Hardness as $\mathrm{CaCO}_{3}$ & $"$ & 10.0 \\
\hline Free Carbon Dioxide as $\mathrm{CO}_{2}$ & 0.10 & 0.10 \\
\hline Total Iron & 0.05 & 0.10 \\
\hline Silica as $\mathrm{SiO}_{2}$ & 0.05 & 0.10 \\
\hline $\begin{array}{l}\text { Total Ammoniacal Nitrogen } \\
\text { (Free and Saline) as } \mathrm{NH}_{3}\end{array}$ & 0.02 & 2.0 \\
\hline
\end{tabular}

